\title{
tक्जि
}

INSTITUTO DE PESQUISAS ENERGÉTICAS E NUCLEARES

Autarquia associada à Universidade de São Paulo

\section{ESTUDO DA RESPONSABILIDADE SOCIAL DO INSTITUTO DE PESQUISAS ENERGÉTICAS E NUCLEARES DE SÃO PAULO (IPEN/CNEN - SP)}

Rita de Cássia Mutarelli

Dissertação apresentada como parte dos requisitos para obtenção do Grau de Mestre em Ciências na Área de Tecnologia Nuclear - Reatores

Orientadora:

Profa. Dra. Gaianê Sabundjian

São Paulo, 2014 
DEDICATÓRIA

À minha filha, Giovanna Mutarelli de Molnary. 
AGRADECIMENTOS

"Cada pessoa que passa em nossa vida, passa sozinha, é por que cada pessoa é única e nenhuma substitui a outra! Cada pessoa que passa em nossa vida passa sozinha e não nos deixa só porque deixa um pouco de si e leva um pouquinho de nós. Essa é a mais bela responsabilidade da vida e a prova de que as pessoas não se encontram por acaso."

Charles Chaplin 
Tenho muito a agradecer a todos que passaram pelo meu caminho durante o período de realização do mestrado e, com certeza, deixaram um pouco de si. Os momentos de alegria me permitiram acreditar na beleza da vida, e os de sofrimento serviram para um crescimento pessoal único.

Primeiramente agradeço à Profa. Dra. Gaianê Sabundjian por acreditar em mim e pela orientação. Agradeço por seus ensinamentos, tanto pessoais como acadêmicos, orientações, palavras de incentivo, críticas construtivas, paciência e dedicação (inclusive aos finais de semana). Gaianê, você é uma pessoa ímpar, na qual busco inspiração para me tornar melhor em tudo o que faço e irei fazer daqui para frente. Tenho orgulho em dizer que fui orientada por você.

Agradeço a todos os professores do IPEN pelos ensinamentos, dedicação, paciência e ajuda na realização de todas as disciplinas que, sem dúvida, contribuíram muito para a realização desse trabalho. Agradeço, especialmente, ao Prof. Dr. Antônio Carlos de Oliveira Barroso e ao Prof. Dr. Luiz Antônio Mai.

Agradeço a todos os professores da FEA, em especial ao Prof. Dr. José Afonso Mazzon, pela dedicação, atenção, disponibilidade e pela imensa contribuição com seus ensinamentos em pesquisa, sem os quais não conseguiria realizar esse trabalho.

Agradeço à Prof. Dra. Ana Cecília de Souza Lima e ao Prof. Dr. Antônio Teixeira e Silva pelas contribuições dadas a esse trabalho durante o seminário de área.

Agradeço a todos os funcionários e colaboradores do IPEN (não citarei nomes, pois não quero esquecer ninguém). Agradeço a todos vocês, não apenas pelos momentos de descontração, mas principalmente pela ajuda na realização da pesquisa, que foi de grande importância para a realização desse trabalho. 
Agradeço a todos os meus amigos da Editora Globo (não citarei nomes, pois também não quero esquecer ninguém) pelo apoio, principalmente nos momentos em que tive que me ausentar para execução das tarefas relacionadas com o mestrado.

Agradeço à diretora da UNIP, que também é minha prima e amiga, Sandra Regina Kuka Mutarelli, pelo incentivo e apoio.

Agradeço aos meus pais, Estefano Ricardo Mutarelli e Maria Luiza Mutarelli, por me ensinarem que o estudo é a maior herança que os pais podem deixar para os filhos.

Agradeço às minhas irmãs, cunhados e sobrinhos por me perdoarem por todas as vezes que não pude participar de um evento familiar devido às minhas atividades do mestrado. Em especial, gostaria de agradecer ao meu cunhado, Prof. Dr. Francisco Luciano Pontes Jr., que sempre incentivou e me inspirou na realização do mestrado.

Agradeço ao meu querido José João dos Santos, que sempre está ao meu lado nos momentos bons e ruins e, com certeza, sem a sua ajuda esta etapa da minha vida não teria sido tão gratificante.

Agradeço à minha querida filha, Giovanna Mutarelli de Molnary, minha vida, minha alma, minha luz, minha inspiração, a quem eu dedico esse trabalho.

Agradeço ao Instituto de Pesquisas Energéticas e Nucleares, ao Centro de Engenharia Nuclear, á Comissão Nacional de Energia Nuclear e à Universidade de São Paulo pela oportunidade, pelo incentivo e principalmente por todo apoio concedido no transcorrer da execução do meu trabalho.

Agradeço a Deus por estar sempre ao meu lado! 
Por fim agradeço a todos os empreendedores que acreditam que a responsabilidade social é parte integrante da dinâmica organizacional.

“(..) nada de parar o crescimento enquanto houver pobres e desigualdades sociais gritantes; mas é imperativo que esse crescimento mude no que se refere a suas modalidades $e$, sobretudo, à divisão de seus frutos. Precisamos de outro crescimento para outro desenvolvimento."

Ignacy Sachs 


\section{ESTUDO DA RESPONSABILIDADE SOCIAL DO INSTITUTO DE PESQUISAS ENERGÉTICAS E NUCLEARES DE SÃO PAULO (IPEN/CNEN - SP)}

\section{Rita de Cássia Mutarelli}

\section{RESUMO}

Ao longo dos anos, a evolução do conceito socioambiental tem se solidificado por meio de programas, conferências e diversas atividades que ocorrem no Brasil e no mundo. A sustentabilidade e a responsabilidade social passaram a ser parte integrante do cotidiano das organizações. O Instituto de Pesquisas Energéticas e Nucleares (IPEN) ${ }^{1}$, que é o foco desse trabalho tem como parte da sua missão o compromisso com a melhoria da qualidade de vida da população brasileira e com base na missão do IPEN e na falta de instrumentos de avaliação de ações socioambientais, este trabalho tem como objetivo propor um instrumento que avalie a responsabilidade social e sirva como uma opção metodológica fortemente comprometida com o aprimoramento do Instituto. Por meio de indicadores e dimensões, construiu-se uma metodologia que busca avaliar a responsabilidade social e identificar tanto os pontos fortes como os fracos. Essa metodologia foi aplicada ao IPEN, e os resultados apresentados nesse trabalho identificaram aspectos positivos com respeito às suas ações para com o público interno e pontos a serem melhorados com relação ao seu público externo. Os resultados foram satisfatórios, no entanto, esse trabalho poderá ter uma continuidade, pois 0 tema é amplo e não se esgota nesse estudo. Por meio dessa pesquisa, os gestores do IPEN poderão identificar ações socioambientais viáveis que possam ser implementadas no Instituto.

\footnotetext{
${ }^{1}$ O IPEN é uma autarquia estadual associada à Universidade de São Paulo (USP), gerenciada pela Comissão Nacional de Energia Nuclear (CNEN) e subordinada ao Ministério de Ciência e Tecnologia.

A CNEN é uma autarquia federal criada em 10 de outubro de 1956 e vinculada ao Ministério de Ciência e Tecnologia. Como órgão superior de planejamento, orientação, supervisão e fiscalização, estabelece normas e regulamentos em radioproteção e licencia, fiscaliza e controla a atividade nuclear no Brasil. A CNEN desenvolve ainda pesquisas na utilização de técnicas nucleares em benefício da sociedade (CNEN - ATIVIDADES, 2012).
} 


\title{
STUDY OF SOCIAL RESPONSIBILITY OF THE NUCLEAR AND ENERGY RESEARCH INSTITUTE OF SÃO PAULO (IPEN/CNEN-SP)
}

\author{
Rita de Cássia Mutarelli
}

\begin{abstract}
Over the years, the socio-environmental concept has grown through programs, conferences and several activities that have been held in Brazil and worldwide. Sustainability and social responsibility are now an integral part of everyday life of organizations The Instituto de Pesquisas Energéticas e Nucleares (IPEN) ${ }^{2}$, which is the focus of this research, is committed to the improvement of Brazilian quality of life. Based on IPEN's mission, and due to the lack of tools for assessing socio-environmental actions, this research aims to propose an assessment tool for social responsibility, which may also be a methodological resource committed to the improvement of the Institute. Through indicators and dimensions, a methodology to assess social responsibility and identify both strengths and weaknesses was designed. The methodology was administered to IPEN, and the results demonstrated positive aspects regarding actions towards the internal publics and negative aspects towards the external publics that require improvement. The results obtained were satisfactory. Nevertheless, as the subject of this study is a broad theme, further studies are suggested. IPEN's board may use the results of this research as a tool to help them identify feasible socio-environmental actions to be implemented in the institute.
\end{abstract}

\footnotetext{
${ }^{2}$ IPEN is a State of São Paulo autarchy, associated to the University of São Paulo - USP for educational purposes and supported and operated technically and administratively by the National Nuclear Energy Commission (CNEN), a federal agency of the Ministry of Science and Technology.

CNEN is a federal agency created in October 10, 1956 and under the Ministry of Science and Technology. As top planning agency, guidance, supervision and inspection, standards and regulations on radiation protection and licenses, supervises and controls the nuclear activity in Brazil. CNEN also conducts research on the use of nuclear techniques for the benefit of society (CNEN - ATIVIDADES, 2012).
} 


\section{SUMÁRIO}

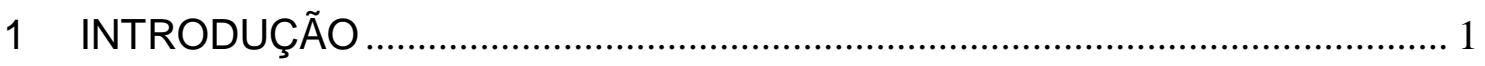

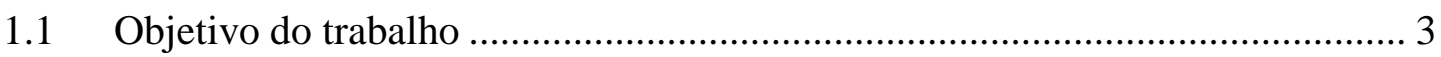

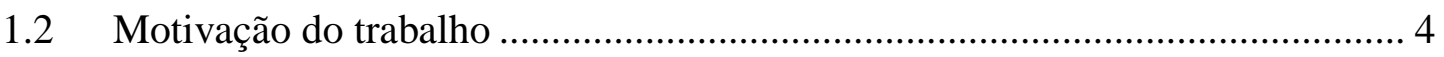

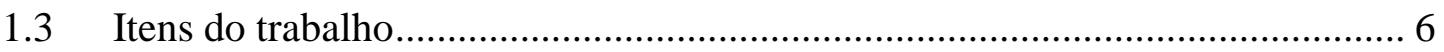

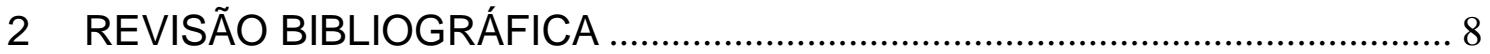

2.1 Evolução da responsabilidade social nas empresas ........................................... 8

2.2 Definições da responsabilidade social ............................................................ 12

2.3 A questão ambiental e o desenvolvimento sustentável ................................. 15

2.4 Histórico da atuação social no Brasil ................................................................ 23

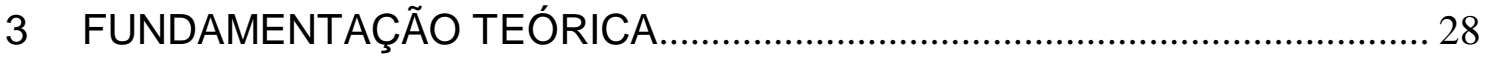

3.1 Metodologias e indicadores da responsabilidade social ............................... 28

3.1.1 Indicadores de Desenvolvimento Sustentável da Organização das Nações

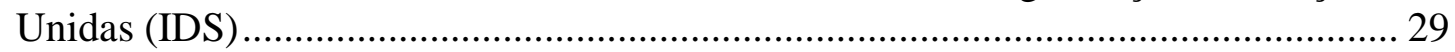

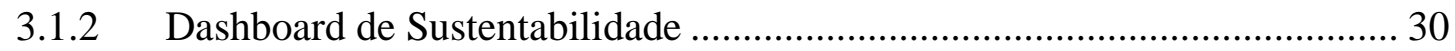

3.1.3 Barômetro de Sustentabilidade.................................................................. 31

3.1.4 Global Reporting Initiative (GRI) …...................................................... 33

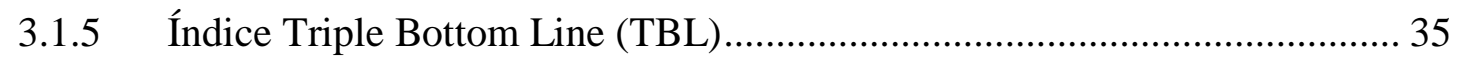

3.1.6 Métricas de sustentabilidade da Instituição dos Engenheiros Químicos da

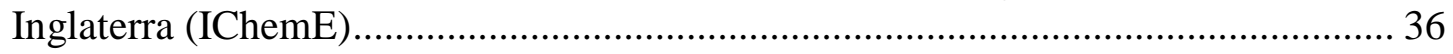

3.1.7 Dow Jones Sustainability Index (DJSI) ................................................... 36

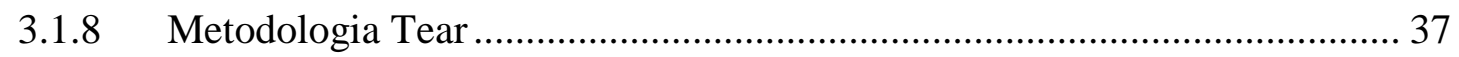

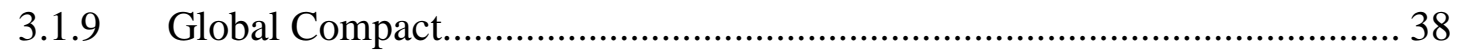

3.1.10 Indicadores Ethos de Responsibilidade Social Empresarial ....................... 40

3.2 Análise comparativa entre as metodologias e indicadores ............................ 42

3.3 Limitações das metodologias e indicadores.................................................... 45

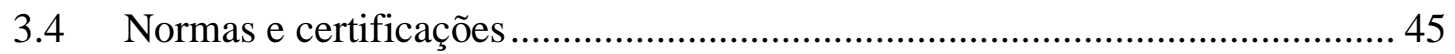

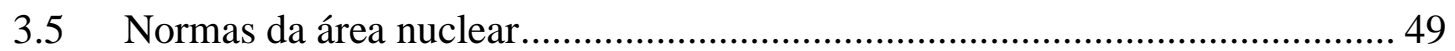

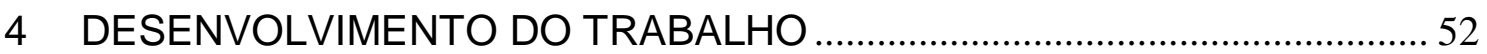

4.1 Proposição do modelo teórico e hipóteses de pesquisa .................................... 59

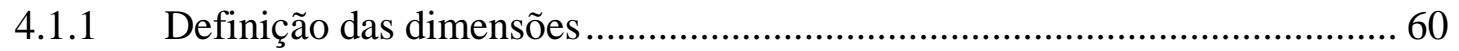

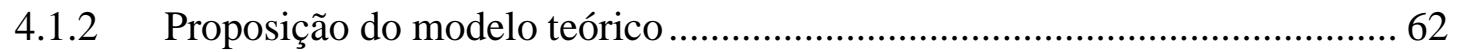

4.1.3 Desenvolvimento das escalas e hipóteses de pesquisa................................ 65

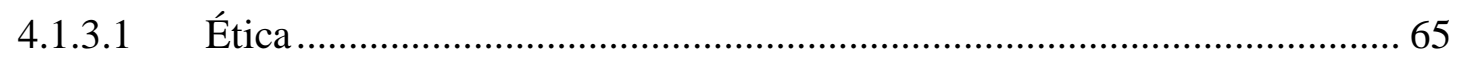

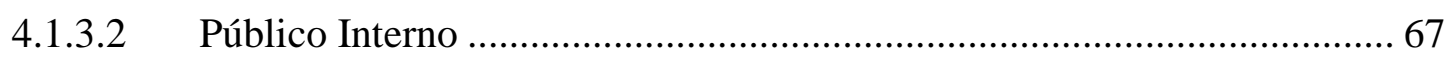




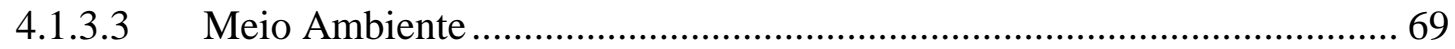

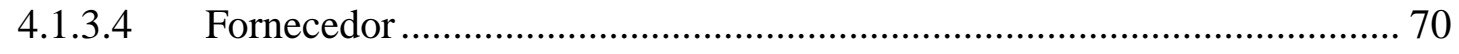

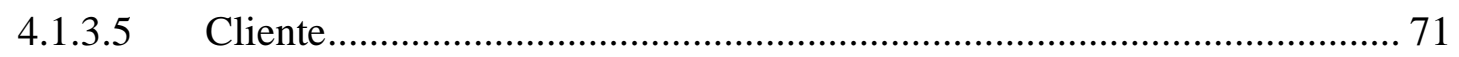

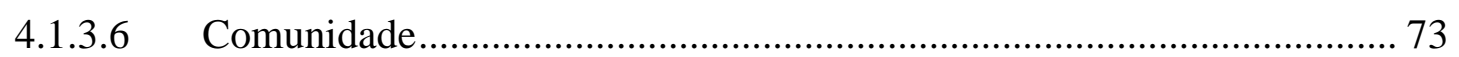

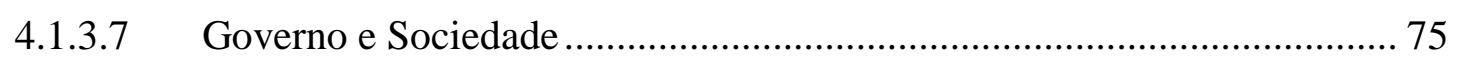

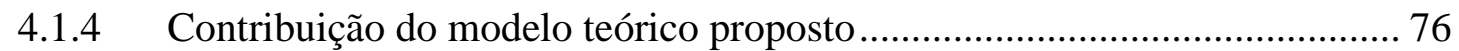

4.2 Metodologia da pesquisa empírica................................................................... 77

4.2.1 Validação do instrumento de coleta de dados .............................................. 79

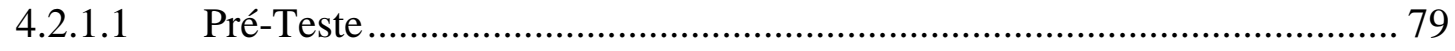

4.2.2 Definição do instrumento de coleta de dados............................................... 84

4.2.3 Estudo conclusivo, descritivo e quantitativo .............................................. 87

4.2.3.1 Definição da amostra utilizada na pesquisa ............................................. 88

4.2.3.2 Metodologia de coleta de dados ................................................................. 90

4.2.3.3 Metodologia de análise de dados ............................................................ 91

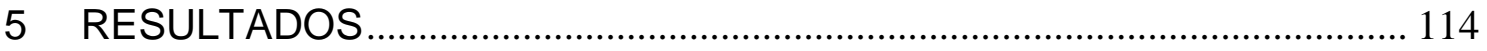

5.1 Preparação do banco de dados .................................................................... 114

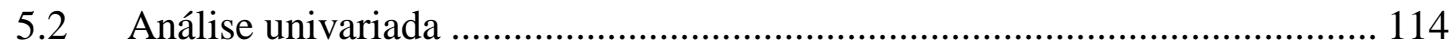

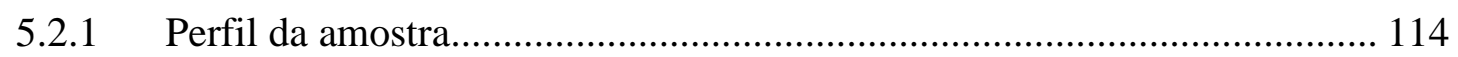

5.2.2 Percepção da amostra quanto à RS do IPEN ............................................. 118

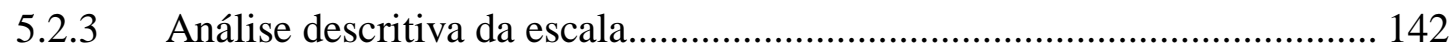

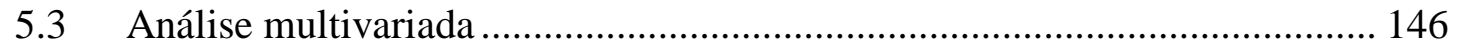

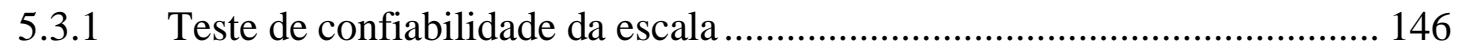

5.3.2 Avaliação do Outer Model (Modelo de Mensuração)................................ 148

5.3.3 Avaliação do Inner Model (Modelo Estrutural) e das hipóteses ................. 155

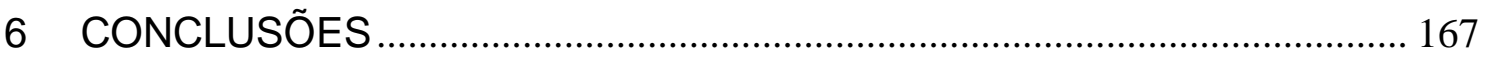

6.1 Conclusões do estudo e implicações acadêmicas ........................................ 167

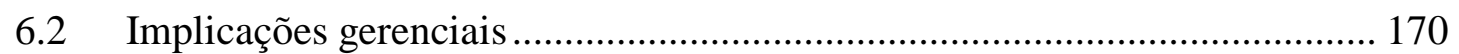

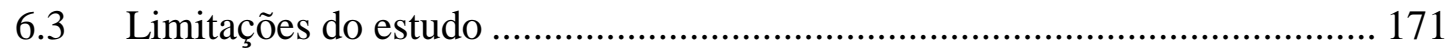

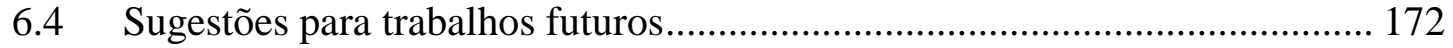

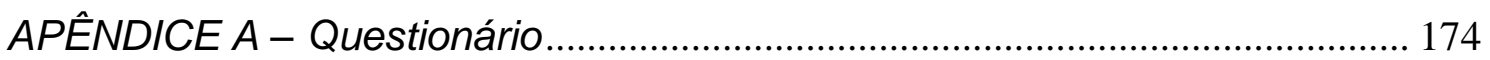

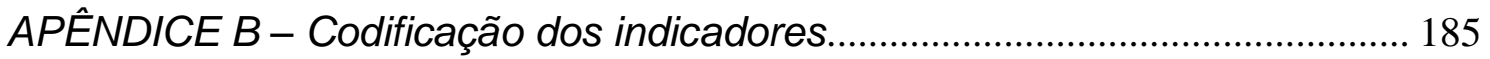

ANEXO A - Normas de todos os grupos vigentes na CNEN............................ 186

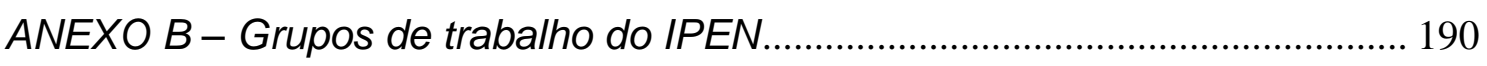

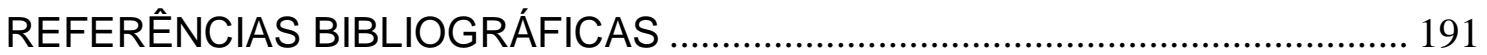




\section{LISTA DE TABELAS}

TABELA 1.1 - Líderes em sustentabilidade por setor (DJSI) ................................. 5

TABELA 2.1- Eventos e fatos importantes do desenvolvimento sustentável .... 16

TABELA 3.1 - Análise do escopo das ferramentas de mensuração da

Responsabilidade Social

TABELA 3.2 - Análise da aplicabilidade das ferramentas de mensuração da

Responsabilidade Social

TABELA 3.3 - Princípios das normas ISO 14063, GRI e ISO 26000 .................. 48

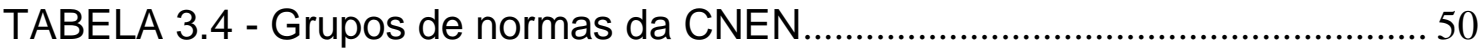

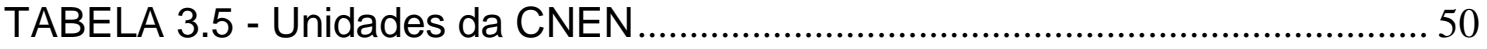

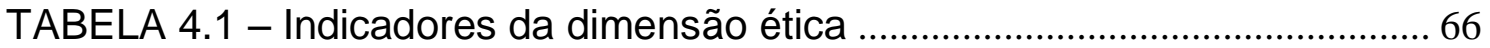

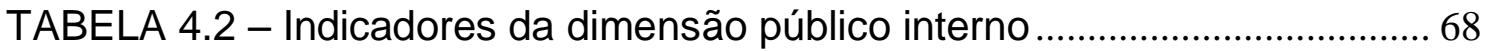

TABELA 4.3 - Indicadores da dimensão meio ambiente .......................................6 69

TABELA 4.4 - Indicadores da dimensão fornecedor ............................................. 71

TABELA 4.5 - Indicadores da dimensão cliente ................................................... 72

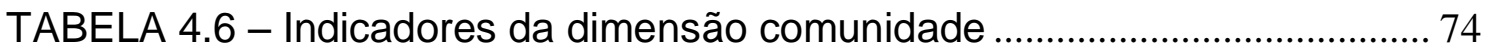

TABELA 4.7 - Indicadores da dimensão governo e sociedade ............................ 76

TABELA 4.8 - Metodologias e indicadores socioambientais ................................. 77

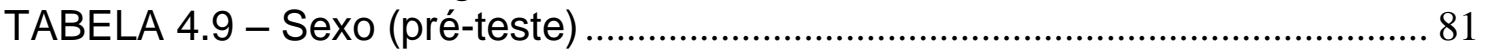

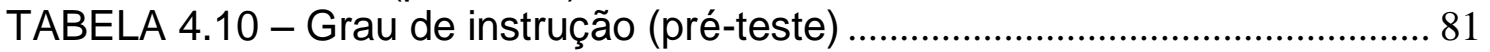

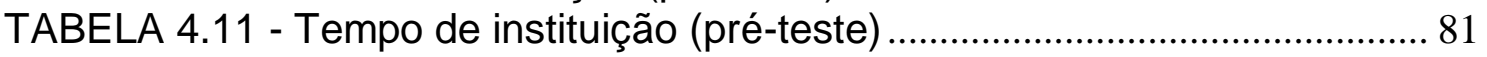

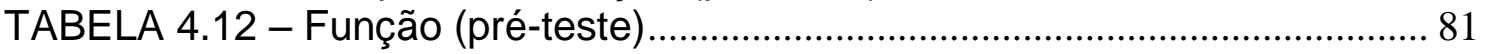

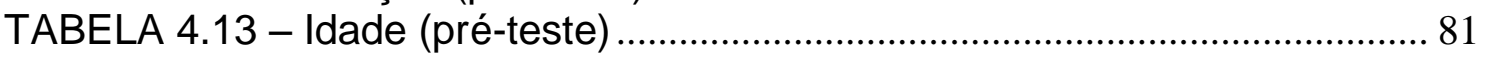

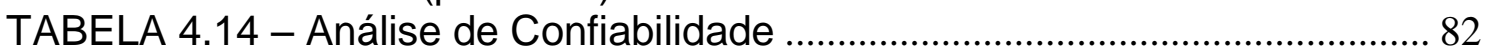

TABELA 4.15 - Perfil da Força de Trabalho do IPEN ........................................... 90

TABELA 4.16 - Classificação da confiabilidade a partir do coeficiente Alfa de

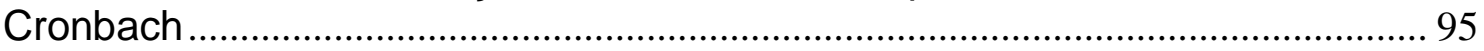

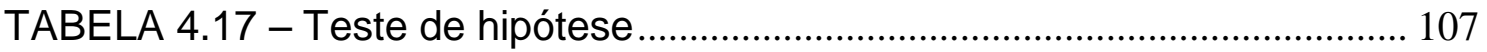

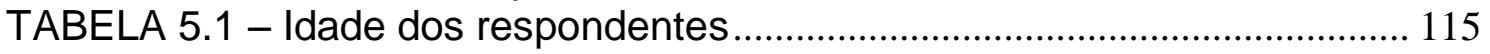

TABELA 5.2 - Centro de pesquisa dos respondentes ........................................ 116

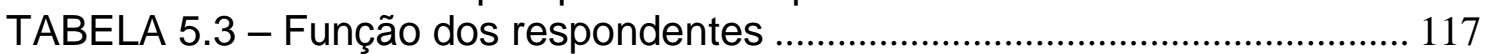

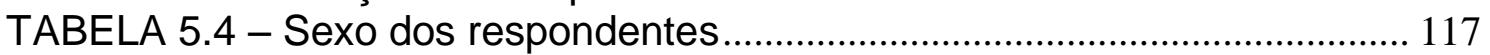

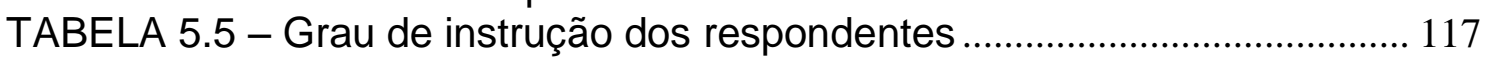

TABELA 5.6 - Tempo de instituição dos respondentes ..................................... 118

TABELA 5.7 - Pontuação média por sexo ............................................................ 122

TABELA 5.8 - Pontuação média por faixa etária .................................................. 126

TABELA 5.9 - Pontuação média por tempo de trabalho na Instituição............. 130

TABELA 5.10 - Pontuação média por função ......................................................... 135

TABELA 5.11 - Pontuação média por grau de instrução ................................... 139

TABELA 5.12 - Pontuação média por Centro de Pesquisa ............................... 140

TABELA 5.13 Medidas Descritivas - Escalas da Responsabilidade Social do IPEN

TABELA 5.14 - Análise de Confiabilidade Alfas de Cronbach - após revisão 147

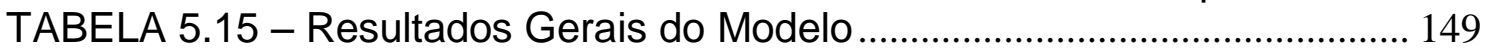

TABELA 5.16 - Cargas Fatoriais Padronizadas - Outer Loadings.................... 150

TABELA 5.17 - Validade Discriminante .............................................................. 153

TABELA 5.18 - Cargas (Outer Loadings) e Cargas Cruzadas (Cross-Loadings) 
TABELA 5.19 - Teste dos Path Coefficients................................................... 156

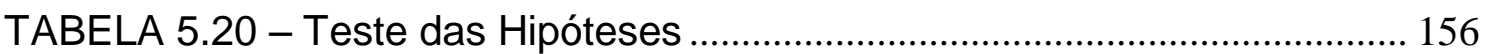

TABELA 5.21 - Análise dos Path Coefficients por Bootstrapping...................... 158

TABELA 5.22 - Análise das Cargas do Outer Model por Bootstrapping ......... 159

TABELA 5.23 - Effect Size f2 …………………………................................. 160

TABELA 5.24 - Cross-Validate Redundancy (Q2) ........................................... 161

TABELA 5.25 - Critérios de Avaliação e Tamanhos Relativos dos Segmentos

FIMIX.

TABELA 5.26 - Path Coefficients para Dois Clusters ....................................... 163

TABELA 5.27 - Ordem de Magnitude dos Path Coefficients ............................. 163

TABELA 5.28 - Perfil dos respondentes por Cluster e amostra total ................. 164

TABELA 5.29 - Análise de variância (ANOVA) para dois clusters ..................... 165

TABELA A.1 - Grupo 1 - Instalações Nucleares ................................................. 186

TABELA A.2 - Grupo 2 - Controle de Materiais Nucleares, Proteção Física e

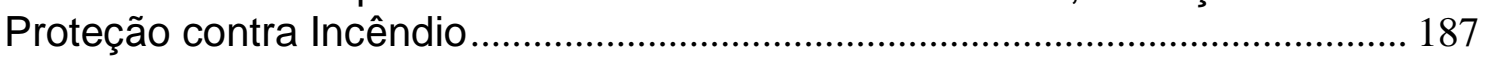

TABELA A.3 - Grupo 3 - Proteção Radiológica ................................................... 187

TABELA A.4 - Grupo 4 - Materiais, Minérios e Minerais Nucleares .................... 188

TABELA A.5 - Grupo 5 - Transporte de Materiais Radioativos ............................ 188

TABELA A.6 - Grupo 6 - Instalações Radiativas .................................................. 188

TABELA A.7 - Grupo 7 - Certificação e Registro de Pessoas............................... 189

TABELA A.8 - Grupo 8 - Rejeitos Radioativos.................................................... 189

TABELA B.1 - Grupo de Trabalho para Atividades de Licenciamento do IPEN 


\section{LISTA DE FIGURAS}

FIGURA 1.1 - Sequência lógica do estudo.............................................................. 7

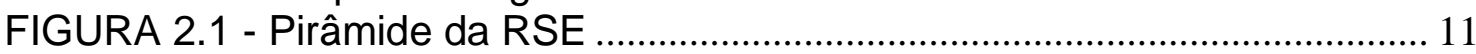

FIGURA 3.1 - Quadro da Comissão das Nações Unidas sobre o

Desenvolvimento Sustentável................................................................................ 30

FIGURA 3.2 - Dashboard of Sustainability ........................................................... 31

FIGURA 3.3 - Barometer of Sustainability .......................................................... 33

FIGURA 3.4 - Estrutura Hierárquica do Global Report Initiative........................... 34

FIGURA 3.5 - Triple Bottom Line .................................................................... 35

FIGURA 3.6 - Métricas de sustentabilidade da Instituição de Engenheiros

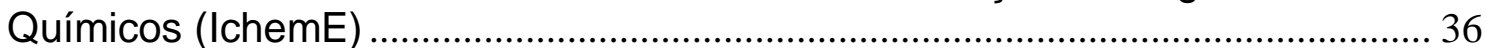

FIGURA 3.7 - Summary of Dow Jones Sustainability Indexes............................. 37

FIGURA 3.8 - Metodologia Tear - Tecendo Redes Sustentáveis ......................... 38

FIGURA 3.9 - A Evolução das comunicações nas normas internacionais de

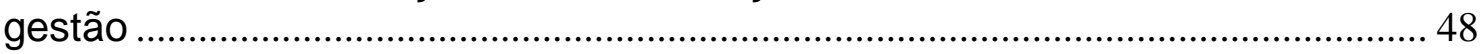

FIGURA 4.1 - Etapas do desenvolvimento do modelo teórico proposto ............ 52

FIGURA 4.2 - Etapas dos procedimentos metodológicos ........................................ 54

FIGURA 4.3 - Foto panorâmica do IPEN ………………...................................... 59

FIGURA 4.4 - Modelo teórico proposto .................................................................. 64

FIGURA 4.5 - Resultado da pontuação das dimensões da Responsabilidade

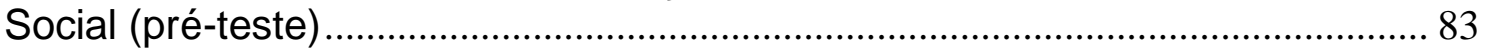

FIGURA 5.1- Projeção da distribuição por faixa etária do IPEN ......................... 115

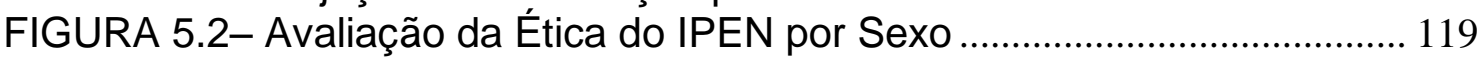

FIGURA 5.3- Avaliação RS do IPEN para com o Público Interno por Sexo ... 119

FIGURA 5.4 - Avaliação do Tratamento Dado ao Meio Ambiente pelo IPEN por

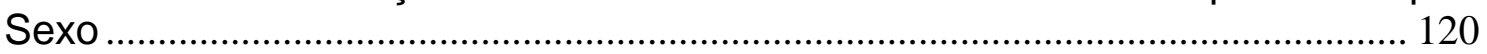

FIGURA 5.5 - Avaliação do Relacionamento do IPEN com os Fornecedores por

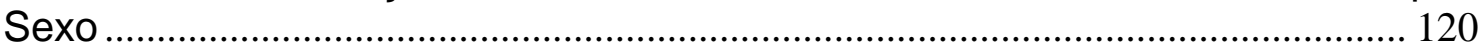

FIGURA 5.6 - Avaliação do Relacionamento do IPEN com os seus Clientes por

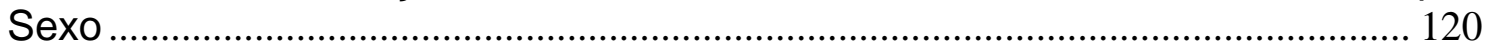

FIGURA 5.7- Avaliação do Relacionamento do IPEN com a Comunidade do

Entorno por Sexo

FIGURA 5.8 - Avaliação do Relacionamento do IPEN com o Governo e a

Sociedade por Sexo

FIGURA 5.9 - Avaliação da Ética do IPEN por Faixa Etária...................................... 122

FIGURA 5.10 - Avaliação RS do IPEN para com o Público Interno por Idade 123

FIGURA 5.11 - Avaliação do Tratamento ao Meio Ambiente Dado pelo IPEN

por Idade

FIGURA 5.12 - Avaliação do Relacionamento do IPEN com os Fornecedores

por Idade

FIGURA 5.13 - Avaliação do Relacionamento do IPEN com os seus Clientes

por Idade

FIGURA 5.14 - Avaliação do Relacionamento do IPEN com a Comunidade do

Entorno por Idade

FIGURA 5.15 - Avaliação do Relacionamento do IPEN com o Governo e a

Sociedade por Idade

FIGURA 5.16 - Avaliação da Ética do IPEN por Tempo de Trabalho na Instituição 
FIGURA 5.17 - Avaliação RS do IPEN para com o Público Interno por Tempo de Trabalho na Instituição

FIGURA 5.18 - Avaliação do Tratamento Dado ao Meio Ambiente pelo IPEN por Tempo de Trabalho na Instituição................................................................ 128 FIGURA 5.19 - Avaliação do Relacionamento do IPEN com os Fornecedores por Tempo de Trabalho na Instituição ................................................................ 128 FIGURA 5.20 - Avaliação do Relacionamento do IPEN com os seus Clientes por Tempo de Trabalho na Instituição .............................................................. 129 FIGURA 5.21 - Avaliação do Relacionamento do IPEN com a Comunidade do Entorno por Tempo de Trabalho na Instituição

FIGURA 5.22 - Avaliação do Relacionamento do IPEN com o Governo e a Sociedade por Tempo de Trabalho na Instituição.

FIGURA 5.23 - Avaliação da Ética do IPEN por Função

FIGURA 5.24 - Avaliação RS do IPEN ára com o Público Interno por Função

FIGURA 5.25 - Avaliação do Tratamento Dado ao Meio Ambiente pelo IPEN por Função

FIGURA 5.26 - Avaliação do Relacionamento do IPEN com os Fornecedores por Função

FIGURA 5.27- Avaliação do Relacionamento do IPEN com os seus Clientes por Função

FIGURA 5.28- Avaliação do Relacionamento do IPEN com a Comunidade em

Torno por Função

FIGURA 5.29- Avaliação do Relacionamento do IPEN com o Governo e a

Sociedade por Função

FIGURA 5.30 - Avaliação da Ética do IPEN por Grau de Instrução ................... 135

FIGURA 5.31- Avaliação RS do IPEN para com o Público Interno por Grau de

Instrução.

FIGURA 5.32- Avaliação do Tratamento Dado ao Meio Ambiente pelo IPEN

por Grau de Instrução

FIGURA 5.33 - Avaliação do Relacionamento do IPEN com os Fornecedores

por Grau de Instrução

FIGURA 5.34- Avaliação do Relacionamento do IPEN com os seus Clientes por Grau de Instrução

FIGURA 5.35- Avaliação do Relacionamento do IPEN com a Comunidade do

Entorno por Grau de Instrução 138

FIGURA 5.36- Avaliação do Relacionamento do IPEN com o Governo e a

Sociedade por Grau de Instrução

FIGURA 5.37 - Pontuação Média por Centro de Pesquisa

FIGURA 5.38- Avaliação Geral da RS IPEN Independentemente do Perfil dos

Respondentes

FIGURA 5.39 - O Modelo Teórico Proposto Testado 


\section{LISTA DE ABREVIATURAS}

$\begin{array}{ll}\text { ABNT } & \text { Associação Brasileira de Normas Técnicas } \\ \text { ABRINQ } & \text { Associação Brasileira dos Fabricantes de Brinquedos } \\ \text { ACDE } & \text { Associação dos Dirigentes Cristãos de Empresas } \\ \text { AIEA } & \text { Agência Internacional de Energia Atômica } \\ \text { AMOS } & \text { Analysis of Moment Structures } \\ \text { AVE } & \text { Average Variance Extracted } \\ \text { BIC } & \text { Bayes Information Criterion } \\ \text { CAIC } & \text { Consistent Akaike Information Criterion } \\ \text { CASI } & \text { Comitê de Avaliação de Segurança do Instituto } \\ \text { CB } & \text { Centro de Biotecnologia } \\ \text { CBC } & \text { Comitê Brasileiro de Certificação } \\ \text { CB-SEM } & \text { Covariance-Based Structural Equations Modeling } \\ \text { CCCH } & \text { Centro de Células a Combustível e Hidrogênio } \\ \text { CLA } & \text { Centro de Lasers e Aplicações } \\ \text { CCN } & \text { Centro de Combustível Nuclear } \\ \text { CCTM } & \text { Centro de Ciência e Tecnologia de Materiais } \\ \text { CD } & \text { Committee Draft } \\ \text { CDTN } & \text { Centro de Desenvolvimento da Tecnologia Nuclear } \\ \text { CEI } & \text { Centro de Ensino e Informação } \\ \text { CEN } & \text { Centro de Engenharia Nuclear } \\ \text { CERES } & \text { Coalition for Environmentally Responsible Economies } \\ \text { CMMAD } & \text { Comissão Mundial Sobre o Meio Ambiente e Desenvolvimento } \\ \text { CNEN } & \text { Comissão Nacional de Energia Nuclear } \\ \text { CPFL } & \text { Companhia Paulista de Força e Luz } \\ \text { CQMA } & \text { Centro de Química e Meio Ambiente } \\ \text { CR } & \text { Centro de Radiofarmácia } \\ \text { CRCN-CO } & \text { Centro Regional de Ciências Nucleares do Centro-Oeste } \\ \text { CRCN-NE } & \text { Centro Regional de Ciências Nucleares do Nordeste } \\ \text { CRPq } & \text { Centro de Reator de Pesquisa } \\ \text { CSR } & \text { Corporate Social Responsibility } \\ \text { CTR } & \text { Centro de Tecnologia das Radiações } \\ \text { DESA } & \text { Department of Economic and Social Affairs } \\ \text { DIANG } & \text { Distrito de Angra dos Reis } \\ \text { DICAE } & \text { Distrito de Caetité } \\ \text { DIEESE } & \text { Departamento Intersindical de Estatística e Estudos Socioeconômicos } \\ \text { DIFOR } & \text { Distrito de Fortaleza } \\ \text { DIPOA } & \text { Distrito de Porto Alegre } \\ \text { DIRES } & \text { Distrito de Resende } \\ \text { DJSI } & \text { Dow Jones Sustainability Index } \\ \text { DRS } & \text { Diretoria de Radioproteção e Segurança Nuclear } \\ \text { DS } & \text { Desenvolvimento Sustentável } \\ \text { ECA } & \text { Estatuto da Criança e Adolescente } \\ \text { EMBRAPA } & \text { Empresa Brasileira de Pesquisa Agropecuária } \\ \text { EN } & \text { Entropia } \\ & \end{array}$




\begin{tabular}{|c|c|}
\hline ESBRA & Escritório de Brasilia \\
\hline FEA & Faculdade de Economia e Administração - USP \\
\hline FIDES & Fundação Instituto de Desenvolvimento Empresarial e Social \\
\hline FIEB & Federação das Indústrias do Estado da Bahia \\
\hline GEE & Gases do Efeito Estufa \\
\hline GIFE & Grupo de Instituições, Fundações e Empresas \\
\hline GRI & Global Report Initiative \\
\hline GRP & Gerência de Radioproteção \\
\hline IAEA & International Agency Energy Atomic \\
\hline IEA & Instituto de Energia Atômica \\
\hline IBASE & Instituto Brasileiro de Análises Sociais e Econômicas \\
\hline IChemE & Institution of Chemical Engineers \\
\hline IDHO & Indicador de desenvolvimento Humano Organizacional \\
\hline IDS & Indicadores de Desenvolvimento Sustentável \\
\hline IEN & Instituto de Engenharia Nuclear \\
\hline INMETRO & Instituto Nacional de Metrologia, Qualidade e Tecnologia \\
\hline IPCC & Intergovernmental Panel on Climate Change \\
\hline IPEN & Instituto de Pesquisas Energéticas e Nucleares \\
\hline IRD & Instituto de Radioproteção e Dosimetria \\
\hline ISO & International Standardization Organization \\
\hline LAPOC & Laboratório de Poços de Caldas \\
\hline LVP & Latent Variables Path \\
\hline MLE & Maximum Likelihood Estimation \\
\hline MSS & Management System Standards \\
\hline OECD & Organization for Economic Cooperation and Development \\
\hline OMM & Organização Meteorológica Mundial \\
\hline ONG & Organização Não Governamental \\
\hline ONU & Organização das Nações Unidas \\
\hline OSCIP & Organização da Sociedade Civil de Interesse Público \\
\hline PDCA & Plan, Do, Check, Act \\
\hline PLS-SEM & Partial Least Squares - Structural Equations Modeling \\
\hline PNUMA & Programa das Nações Unidas para o Meio Ambiente \\
\hline RFAZ & Relatório Final de Análise de Segurança \\
\hline RPAS & Relatório Preliminar da Análise de Segurança \\
\hline RSC & Responsabilidade Social Corporativa \\
\hline RSE & Responsabilidade Social Empresarial \\
\hline SAM & Sustainable Asset Management \\
\hline SDO & Substâncias que Destroem a Camada de Ozônio \\
\hline SEM & Structural Equation Modeling \\
\hline SPSS & Statistical Package for Social Sciences \\
\hline TBL & Triple Bottom Line \\
\hline TMB & Technical Management Board \\
\hline UNEP & United Nations Environment Programme \\
\hline USP & Universidade de São Paulo \\
\hline
\end{tabular}




\section{INTRODUÇÃO}

As ações socioambientais têm sido um dos temas mais debatidos e propagados para a gestão institucional, tornando-se uma variável importante na estratégia das instituições e do seu desempenho.

As instituições se encontram cada vez mais pressionadas para olhar intensamente o impacto das suas operações dentro e fora de suas paredes e verificar cuidadosamente os impactos de suas políticas e ações nos seus empregados, clientes, comunidades e na sociedade como um todo.

O conceito de Responsabilidade Social (RS) é complexo e dinâmico, com significados diferentes em contextos diversos, exigindo muitas reflexões sobre 0 tema.

O movimento em prol da ação socioambiental ganhou forte impulso e organização no início da década de 1990 em decorrência dos resultados da Primeira e Segunda Conferência Mundial da Indústria sobre gerenciamento ambiental ocorridas em 1984 e 1991 (MELO NETO e FROES, 2001).

Nos anos subsequentes às conferências, surgiram vários movimentos que cobraram mudanças socioambientais. Esses movimentos abrangeram uma ampla variedade de organizações não governamentais, movimentos sociais e sindicatos, que envolveram a questão social e ambiental como uma dimensão de importante atuação.

Segundo Melo Neto e Froes (2001), muitas instituições iniciaram uma nova postura com esse propósito que resultou em importantes decisões e estratégias práticas. Tal postura fundamentou-se nos seguintes parâmetros:

bom relacionamento com a comunidade;

bom relacionamento com os organismos ambientais;

estabelecimento de uma política ambiental;

eficiente sistema de gestão ambiental;

garantia de segurança dos empregados e das comunidades vizinhas;

uso de tecnologia limpa; 
investimentos substanciais em proteção ambiental;

definição de um compromisso ambiental;

associação das ações ambientais com os princípios estabelecidos para um desenvolvimento sustentável;

atuação ambiental com base na agenda 21 (CNUMAD, 1995);

contribuição para o desenvolvimento sustentável dos municípios circunvizinhos.

Apesar de ser um tema relativamente novo, o número de instituições que estão aderindo às ações socioambientais é grande, e a tendência é que este número aumente cada vez mais. Isso se deve ao fato que a sustentabilidade começa a ser vista como algo presente no dia a dia das instituições, pois além das atividades produtivas, ela envolve o tratamento dado ao meio ambiente e sua influência e relacionamento com fornecedores, clientes, público interno e externo, com a sociedade, com práticas de governança corporativa e transparência no relacionamento interno e externo.

Segundo o United Nations Departament of Economic and Social Affairs (2001), a conquista do desenvolvimento sustentável é uma aspiração de abrangência universal, e a escolha de indicadores reflete as situações e especificidades de cada país. Eles servem para indicar variações, comportamentos, processos e tendências. Além disso, tentam estabelecer comparações entre países, regiões, empresas, e também podem indicar necessidades e prioridades para formulação, monitoramento e avaliação de políticas sustentáveis.

Esse trabalho abordará três importantes aspectos que devem ser considerados nas questões socioambientais:

1. cidadania corporativa;

2. transparência;

3. capital humano.

A cidadania corporativa abrange uma grande variedade de áreas que tocam a vida das pessoas, incluindo o bem-estar social, cultura e artes, serviços de voluntariado, programas acadêmicos, proteção ambiental e trocas de experiências internacionais. As práticas de cidadania corporativa também podem 
ser traduzidas como um maior comprometimento dos funcionários em relação às empresas, aumentando assim sua produtividade e dando retorno à organização (GUEDES, 2000).

A transparência é um importante fator para melhorar as relações entre as diversas áreas que envolvem a organização e isto se dá, em grande parte, por meio da prestação de contas, tanto em organismos públicos como nos privados. Diversos relatórios em formatos padronizados são gerados e publicados a fim de que toda a sociedade tenha conhecimento das ações da organização em questão e seu planejamento para o futuro (SANTIAGO e GOMES, 2009).

O capital humano deve ser pesquisado sob a ótica da riqueza criada por cada colaborador. Este indicador pode sinalizar a riqueza criada pela organização em relação à mão-de-obra empregada em sua cadeia produtiva. É interessante visualizar, dentro da pirâmide hierárquica da organização, a posição de cada cargo ou função e quais as ações socioambientais que cada uma delas executa. As pessoas que atuam numa organização, seja ela pública, privada ou do terceiro setor, representam o combustível necessário para movimentá-la (MENDES e SILVA, 2009).

Nesse contexto, os gestores das organizações públicas ou privadas têm voltado a sua atenção para as questões socioambientais em suas ações estratégicas e em particular, o Instituto de Pesquisas Energéticas e Nucleares (IPEN), que é o foco desse trabalho, que tem como missão o compromisso com a sociedade no que diz respeito à: "melhoria da qualidade de vida da população brasileira, produzindo conhecimentos científicos, desenvolvendo tecnologias, gerando produtos e serviços e formando recursos humanos nas áreas nuclear e correlatas" (IPEN - MISSÃO, 2011). O IPEN tem buscado sempre o aprimoramento nas questões ambientais e sociais, principalmente no que se refere à energia nuclear, ao bom funcionamento de suas instalações e ao bemestar social.

\subsection{Objetivo do trabalho}

Tendo em vista a contextualização do estudo incluindo o tema a ser pesquisado, o setor escolhido e a decorrente questão de pesquisa, o objetivo 
desse trabalho é propor e testar um modelo teórico para descrever e analisar a responsabilidade socioambiental do IPEN.

Para tal, foram desenvolvidas as seguintes etapas:

1. Uma revisão crítica da literatura, abrangendo os seguintes assuntos: a evolução da responsabilidade social, as definições da responsabilidade social, a questão ambiental do desenvolvimento sustentável, o histórico da atuação social no Brasil, as metodologias existentes e os indicadores socioambientais;

2. A proposição de um modelo conceitual elaborado com base na revisão bibliográfica, discriminando o papel de cada dimensão no constructo $^{3}$ e seus indicadores;

3. Realização de uma pesquisa empírica de caráter descritivo com os funcionários do IPEN.

4. Teste e validação do modelo.

\subsection{Motivação do trabalho}

A motivação desse trabalho baseia-se na crescente importância das questões sociais e ambientais, já que essas ações, por menor que sejam, podem gerar um enorme benefício para a organização no futuro.

O IPEN é uma instituição que tem como missão o compromisso com a sociedade e já tem em prática uma série de ações ambientais e sociais de grande repercussão (IPEN - AÇÕES DE CIDADANIA, 2011). Dentre essas ações, podem ser citadas:

\footnotetext{
${ }^{3}$ Constructo são componentes da organização medidos indiretamente. Designa, em ciência, um conceito teórico não observável. Tais conceitos são usados na linguagem comum, mas para se tornarem um constructo científico, necessitam de uma definição clara e de um embasamento empírico (ASENDORPF, 2004).
} 
o programa de palestra de divulgação dos benefícios da energia nuclear nas escolas públicas;

o programa bianual de "open house" para os familiares dos funcionários;

o plano médico autogerido;

a pesquisa periódica de clima organizacional;

o grupo de ações para a cidadania que organiza campanhas de doações e atividades em entidades assistenciais;

a organização dos funcionários em forma de sindicato (ASSIPEN) reconhecido pela direção do IPEN/CNEN;

a oferta de cursos de alfabetização, cursos de ensino fundamental, médio e até universitário para aos servidores e parentes, entre outros.

O IPEN, ao longo de sua existência, tem buscado o aprimoramento nas questões ambientais e sociais, principalmente no bem-estar da população. Os resultados desse estudo poderão contribuir de forma significativa para descrever e analisar a responsabilidade social do IPEN e, com base nessa análise, será possível identificar os aspectos que estão bem equacionados e devem ser mantidos e incentivados, bem como os aspectos que podem ser desenvolvidos ou melhorados.

O Dow Jones Sustainability Index (DJSI) comprova que a preocupação com o desempenho social e ambiental das empresas está sendo considerado cada vez mais. A TAB.1.1 apresenta, em ordem alfabética, as empresas que lideraram o ranking nos principais setores em 2012/2013 (S\&P DOW JONES INDEXES, 2012):

TABELA 1.1 - Líderes em sustentabilidade por setor (DJSI)

\begin{tabular}{ll}
\multicolumn{1}{c}{ Líderes do Setor (2012 - 2013) } & Setor \\
\hline Unilever NV & Alimentos e Bebidas \\
\hline Bayerische Motoren Werke AG & Automóveis e Peças \\
\hline Australia \& New Zeland Banking Group Ltd & Bancos \\
\hline Siemens AG & Bens e Serviços Industriais \\
\hline Koninklijk e Philips Eletronics NV & Bens Pessoais e Domésticos \\
\hline GS Enginnering \& Construction Corp & Construção e Materiais \\
\hline GPT Group & Imóveis \\
\hline Telenet Group Holding NV & Mídia \\
\hline
\end{tabular}


TABELA 1.1 - Líderes em sustentabilidade por setor (DJSI) - continuação

\begin{tabular}{ll}
\multicolumn{1}{c}{ Líderes do Setor (2012 - 2013) } & \multicolumn{1}{c}{ Setor } \\
\hline Repsol S.A. & Petróleo e Gás \\
\hline Akzo Nobel NV & Química \\
\hline UPM-Kymmene OYJ & Recursos Básicos \\
\hline Roche Holding AG & Saúde \\
\hline Swiss Re AG & Seguro \\
\hline Itausa - Investimentos Itaú S.A. & Serviços Financeiros \\
\hline Alcatel - Lucent S.A. & Tecnologia \\
\hline KT Corp & Telecomunicações \\
\hline Iberdrola S.A. & Utilitários \\
\hline Lotte Shopping Co Ltd & Varejo \\
\hline Air France KLM & Viagens e Lazer \\
\hline Fonte: (S\&P DOW JONES INDEXES, 2012) &
\end{tabular}

\subsection{Itens do trabalho}

Este estudo está dividido em seis capítulos. O primeiro capítulo compreende a introdução do trabalho, com a contextualização e justificativa do tema.

O segundo capítulo procura, por meio de uma revisão bibliográfica, investigar o tema referente às ações sociais e ambientais nas corporações. Também explora a evolução destes conceitos nas empresas, a questão ambiental e o Desenvolvimento Sustentável e, finalmente, aborda as ações praticadas em organizações brasileiras e estrangeiras, bem como as diversas certificações existentes.

O capítulo três aborda a fundamentação teórica, incluindo as diversas definições de responsabilidade social além das metodologias e indicadores de mensuração.

No quarto capítulo são apresentados a proposição do modelo teórico com suas respectivas hipóteses e os aspectos metodológicos da pesquisa empírica, onde são discutidas a escolha do método, as etapas da pesquisa de campo, a formação das escalas e a metodologia de coleta e análise de dados.

No capítulo cinco, as análises dos resultados do estudo de campo são apresentadas. 
O capítulo seis relata as conclusões geradas a partir da discussão dos resultados, as implicações acadêmicas, as considerações finais e as sugestões para estudos futuros.

$\mathrm{Na}$ FIG. 1.1, a organização do estudo é apresentada de forma esquemática.

No APÊNDICE A, o questionário utilizado na pesquisa de campo é apresentado. No APÊNDICE B estão listadas as codificações dos indicadores utilizados no trabalho.

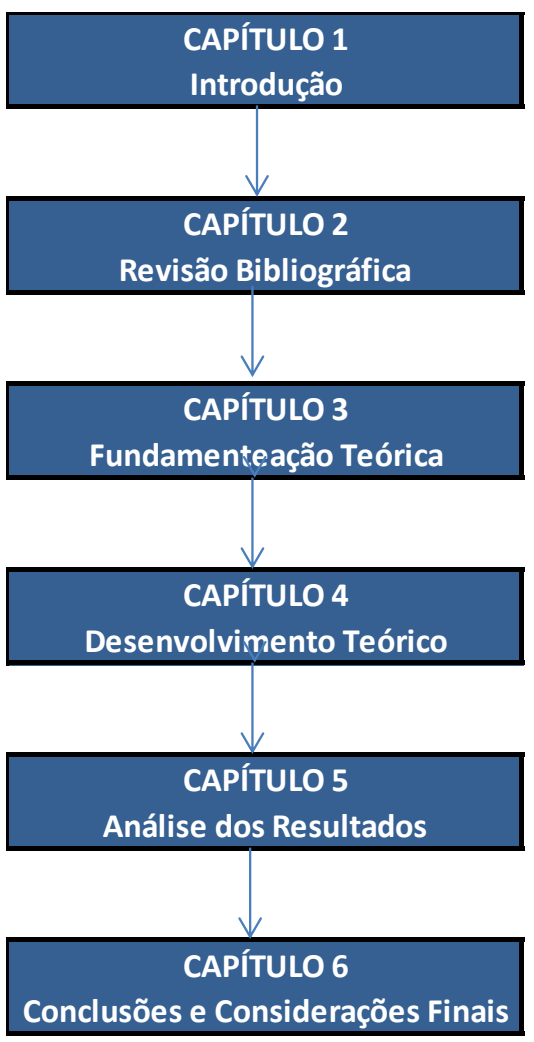

Introdução, contextualização, objetivo e justificativa do estudo.

Evolução do conceito de Responsabilidade Social, a questão da sustentabilidade e histórico no Brasil.

Estudo das diversas definições, metodologias e indicadores que mensuram a Responsabilidade Social.

Proposição do modelo teórico e das hipóteses de pesquisa. Metodologia da pesquisa empírica.

Análise dos resultados conclusivo e descritivo da pesquisa de campo.

Conclusões, limitações, implicações e recomendações para estudo futuro.

FIGURA 1.1 - Sequência lógica do estudo 


\section{REVISÃO BIBLIOGRÁFICA}

A revisão bibliográfica apresentada neste trabalho considera publicações de artigos, livros e reportagens escritas ou faladas sobre responsabilidade social, ações socioambientais, sustentabilidade e desenvolvimento sustentável. Essa revisão está dividida em seções que detalham a evolução e definições da responsabilidade social, as questões ambientais e desenvolvimento sustentável no contexto da responsabilidade social e o histórico da atuação social no Brasil.

\subsection{Evolução da responsabilidade social nas empresas}

Os trabalhos de Charles Eliot (1906), Arthur Hakley (1907) e John Clark (1916) são apontados como as primeiras manifestações sobre o tema "responsabilidade social". No entanto, tais contribuições não receberam apoio por terem sido consideradas de cunho socialista. Essas ideias foram combatidas pela maioria dos empresários e pelo pensamento capitalista, conservador e hegemônico nos meios acadêmicos durante 0 início do século XX (DUARTE e DIAS, 1986).

O conceito da responsabilidade social Corporativa (RSC) tem uma longa e variada história, sendo possível seguir evidências do interesse das empresas pela sociedade ao longo dos séculos. A formalização do tema, entretanto, é um produto do século $X X$, especialmente em seus últimos 50 anos. Outras referências da primeira metade do século XX que abordaram esses aspectos foram: Chester Bernard, com o livro The Functions of the Executive (1938); J. M. Clark's, com o livro Social Control of Business (1939) e Theodore Kreps, com o livro Measurement of the Social Performance of Business (1940) (CARROLL, 1999).

Em 1940, em uma parte da Europa, registrou-se o primeiro apoio empresarial explícito e significativo por parte dos empresários ingleses do setor industrial. Viu-se a necessidade das corporações atuarem com responsabilidade 
em relação aos seus funcionários e contribuírem de forma efetiva para o bemestar da sociedade. O tema responsabilidade social apareceu pela primeira vez em um manifesto subscrito por 120 industriais ingleses em 1942. Tal documento definia que a "responsabilidade dos que dirigem a indústria é manter o equilíbrio justo entre os vários interesses dos públicos, dos consumidores, dos funcionários e dos acionistas. Além disto, dar a maior contribuição possível ao bem-estar da nação como um todo." (DUARTE e DIAS, 1986).

Em 1953, nos Estados Unidos, o livro Social Responsibilities of the Businessman, de Howard Bowen, foi considerado o marco inicial das práticas da responsabilidade social das empresas. A partir de então, o tema recebeu atenção e ganhou espaço, difundindo-se pelos meios empresariais e acadêmicos norteamericanos (CARROLL, 1999).

Segundo Carroll (1999), na década de 1960 os estudos formais sobre o conceito e definição de RSC tiveram início. A visão de que a responsabilidade das empresas deve ir além da maximização do lucro e os recursos devem ser utilizados para fins sociais mais amplos; não simplesmente para os interesses privados dos indivíduos foi predominante. Nesse período, as relações das empresas com agentes externos e os efeitos de suas decisões e ações sobre todo o sistema social começaram a ser reconhecidos.

Em 1970, a RSC já fazia parte de debates públicos relacionados à pobreza, desemprego, relações raciais, desenvolvimento, crescimento econômico, distribuição de renda e poluição. Na ocasião, Friedman (1970), tornou-se opositor às ideias em vigor. $\mathrm{O}$ autor argumentou que os negócios deveriam se limitar à maximização dos lucros e obedecer às leis. Porém, algumas empresas perceberam a importância estratégica de dar publicidade às ações sociais realizadas. As empresas norte-americanas foram as pioneiras na prestação de contas ao público, entretanto, a França foi o primeiro país a transformar a elaboração do balanço social ${ }^{4}$ em uma obrigação. Também nesse período, surgiram as seguintes associações de profissionais interessados em estudar o tema: American Accounting Association e American Institute of Certified Public

\footnotetext{
${ }^{4} \mathrm{O}$ balanço social é uma ferramenta pela qual as empresas são estimuladas a conhecer, sistematizar e apresentar à sociedade informações sobre os seus investimentos internos e externos em ações, iniciativas e projetos relacionados com o social e o ambiental (TORRES e MANSUR, 2008).
} 
Accountants. A partir de então, a responsabilidade social se transformou em um novo campo de estudo (ZAGO, 2007).

Segundo Zago (2007), na década de 1980, poucas modificações no conceito de RSC foram feitas. Os estudos foram direcionados às tentativas de avaliar e operacionalizar a sua relação com o desempenho financeiro e também com temas alternativos como: políticas públicas, éticas nos negócios, teoria da gerência etc. Neste período, a publicação de Drucker (1984) merece destaque. Ele afirmou que o conceito de que a responsabilidade social exclui a maximização dos lucros é inconsistente. Segundo Drucker, lucratividade e responsabilidade social são compatíveis e é possível transformar responsabilidades sociais em oportunidades econômicas.

Wartick e Cochran (1985) vão além das reflexões sobre responsabilidade social; estudam a responsabilidade social versus a responsabilidade econômica e criam modelos que refletem as preocupações entre os negócios e a sociedade. $\mathrm{O}$ conceito de desempenho social, traduzido como ações, atos, obras e seus efeitos também estão identificados, enfatizados e avaliados em sua obra.

Carroll (1991) elaborou o modelo da pirâmide da responsabilidade social focado nas empresas e chamou de "Pirâmide da RSE - Responsabilidade Social Empresarial". Na base ele descreveu as responsabilidades econômicas, depois as responsabilidades legais, éticas e por fim as responsabilidades filantrópicas (FIG. 2.1).

Embora Carroll tenha destacado que essas dimensões não implicam em uma sequência ou estágio do desenvolvimento da RSE, fica claro que a ênfase da sua definição foi dada para a dimensão econômica e legal. Ambas são de fato essenciais, contudo a dimensão ética fica à mercê da compreensão do que são comportamentos éticos e antiéticos, e a responsabilidade filantrópica fica à mercê da compreensão do contexto e de situações particulares das quais se desenvolvem ações e programas sociais específicos. 


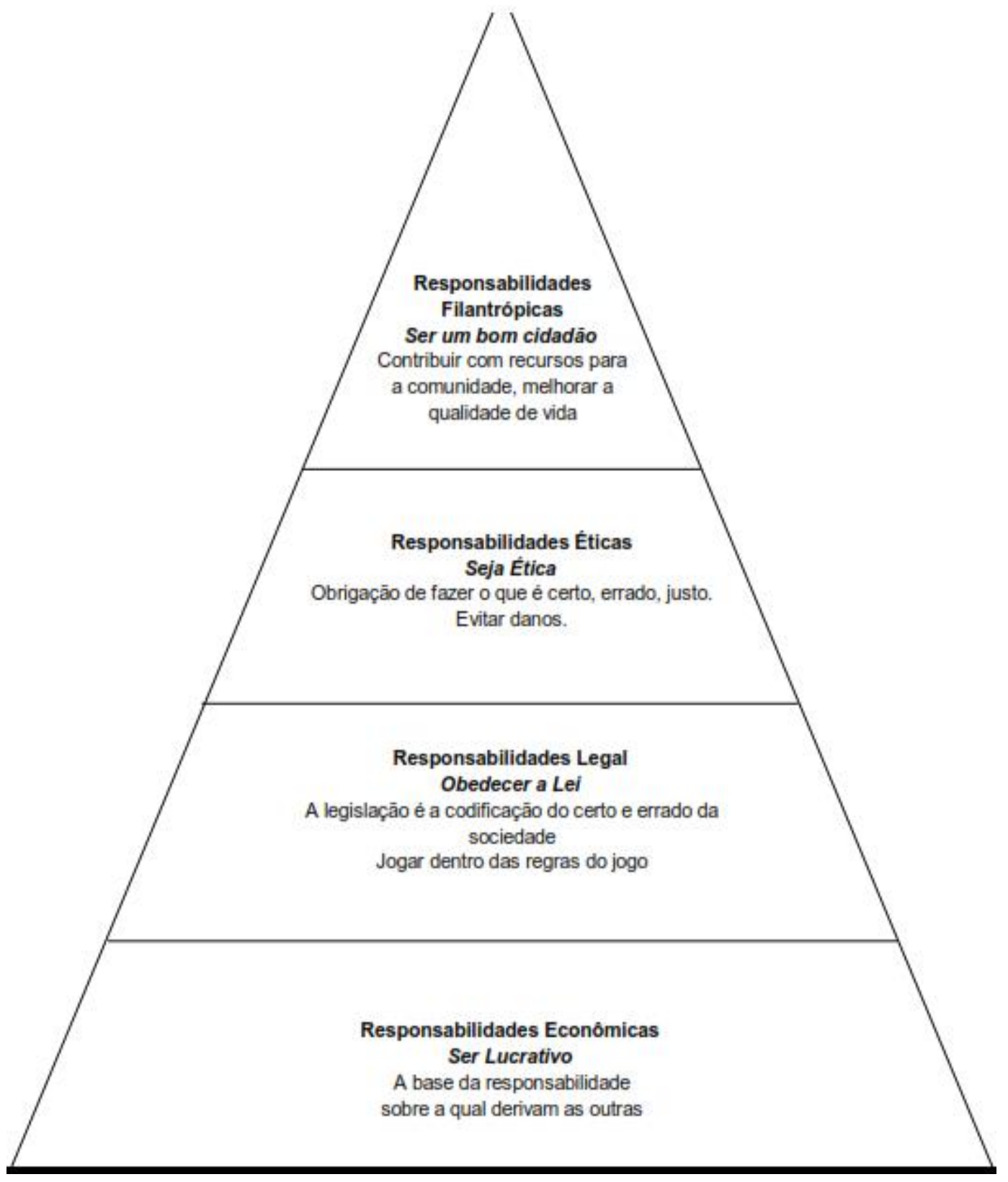

Fonte: (CARROLL, 1991).

FIGURA 2.1 - Pirâmide da RSE

De acordo com Wood \& Jones (1995), o modelo de Carroll é atrativo, mas não se afasta muito da visão clássica dos negócios, enfatizando mais o debate ideológico da RSC do que promovendo o comportamento social responsável. Aliás, Carroll \& Schwartz (2003) entendem que a formatação piramidal não capta a inter-relação entre diferentes níveis e pode passar uma noção de prioridade, sendo o econômico mais importante do que o legal, e assim sucessivamente, o que estaria incorreto. 
O conceito de RSC serviu como base para outros conceitos e temas relacionados como: ética nos negócios, cidadania corporativa, teoria dos stakeholder ${ }^{5}$, modelos de operacionalização da RSC, dentre outros. É comum ver empresas divulgando nos meios de comunicação a participação ou o apoio à projetos sociais por meio de doações, no entanto, a questão da responsabilidade social abrange muito mais do que simples doações financeiras ou materiais. De acordo com Grajew (1999), trata-se "da relação ética, da relação socialmente responsável da empresa em todas as suas ações, em todas as suas políticas, em todas as suas práticas e em todas as suas relações, sejam elas com seu público interno ou externo.".

Uma ação é considerada de caráter filantrópico quando a empresa faz doações financeiras a instituições, fundações, associações comunitárias etc, ou seja, é uma ajuda que ocorre eventualmente. Já quando se fala em responsabilidade social, a empresa age de forma estratégica, focalizada na ética, na qualidade das relações com os stakeholders e na geração de valor, ou seja, são traçadas metas para atender às necessidades sociais, de forma que o lucro da empresa seja garantido, assim como a satisfação do cliente e o seu bem-estar social. Há um comprometimento mais duradouro da organização e, como consequência, há valorização da imagem institucional e da marca, gerando maior lealdade do público interno e externo, principalmente dos consumidores, maior capacidade de recrutar e reter talentos, flexibilidade e capacidade de adaptação às mudanças promovendo sua longevidade (GRAJEW, 1999).

\subsection{Definições da responsabilidade social}

Em administração, é comum encontrar a palavra responsabilidade designando a condição de quem responde pelo seu desempenho no exercício de um cargo, de uma função ou de um poder investido, sendo entendida também como a contrapartida de uma autoridade legalmente constituída. Embora a Responsabilidade Social Empresarial (RSE) seja mais abrangente, a ideia de

\footnotetext{
${ }^{5}$ Stakeholder em uma organização é, por definição, qualquer grupo ou indivíduo que pode afetar ou ser afetado pela realização dos objetivos dessa empresa (FREEMAN, 1984).
} 
responder pelos atos diante da capacidade de realizar escolhas é mantida (BARBIERI e CAJAZEIRA, 2010).

Várias definições para responsabilidade social podem ser encontradas na literatura, como por exemplo:

"Compromisso que uma organização deve ter com a sociedade, expresso por meio de atos e atitudes, que afetem positivamente, de modo amplo, ou a alguma comunidade de modo específico, agindo pro ativamente e coerentemente, no que tange a seu papel específico na sociedade e a sua prestação de contas com ela. $A$ organização neste sentido assume obrigações de caráter moral além das estabelecidas em lei, mesmo que não diretamente vinculadas a suas atividades, mas que possam contribuir para 0 desenvolvimento sustentável dos povos. Assim, numa visão expandida, responsabilidade social é toda e qualquer ação que possa contribuir para a melhoria da qualidade de vida da sociedade." (ASHLEY, 2005).

A expressão Responsabilidade Social Corporativa (RSC), tradução literal de Corporate Social Responsibility, é a mais usada na literatura norte-americana. Corporate é um adjetivo relativo à Corporation, que se refere a uma empresa constituída na forma de uma sociedade anônima de capital aberto, na qual a administração e a propriedade estão separadas. O termo Corporate foi justaposto à expressão Social Responsibility e assim permaneceu. A rigor, a expressão Responsabilidade Social Corporativa relaciona-se apenas com as empresas de capital aberto. Como a responsabilidade social será aqui tratada com vista a contemplar todo o tipo de empresa, será usada a expressão Responsabilidade Social Empresarial (RSE). Assim a RSC é um caso particular da RSE (BARBIERI e CAJAZEIRA, 2010).

A RSE é um tema importante para diversas áreas de conhecimento, como direito, economia, sociologia, ciência política, ética e administração. Esse trabalho foca as principais questões da RSE sob o ponto de vista da administração. Será abordada a teoria das partes interessadas (stakeholders). A teoria contratualista concebe a responsabilidade social da empresa como decorrente de um contrato hipotético ou real com a sociedade (BARBIERI e CAJAZEIRA, 2010).

Segundo Melo Neto e Froes (2001), a responsabilidade social de uma empresa consiste no ato de participar mais diretamente das ações comunitárias na região em que está presente e minimizar possíveis danos ambientais 
decorrentes do tipo de atividade que exerce. Contudo, apoiar o desenvolvimento da comunidade e preservar o meio ambiente não são suficientes para atribuir a uma empresa a condição de socialmente responsável. Os principais fatores da responsabilidade social de uma empresa são:

apoio ao desenvolvimento da comunidade na qual atua;

preservação do meio ambiente;

investimento no bem-estar de seus funcionários, seus dependentes e em um ambiente de trabalho agradável;

comunicações transparentes;

retorno aos acionistas;

sinergia com parceiros;

satisfação dos clientes e/ou consumidores.

Tais fatores direcionam 0 processo de gestão empresarial para 0 fortalecimento da dimensão social da empresa.

Segundo Grajew (2000), Diretor-Presidente do Instituto Ethos:

"O conceito de responsabilidade social está se ampliando, passando da filantropia, que é a relação socialmente compromissada da empresa com a comunidade, para abranger todas as relações da empresa: com seus funcionários, clientes, fornecedores, acionistas, concorrentes, meio ambiente $e$ organizações públicas e estatais.".

Ele ainda menciona que as ações de filantropia correspondem à dimensão inicial do exercício da responsabilidade social. Sua característica principal é a benemerência do empresário, que se reflete nas doações a entidades assistenciais e filantrópicas. No entanto, o conceito logo ganhou maior amplitude, com a ideia da segunda dimensão, que são as ações sociais junto à comunidade. O objetivo dessa dimensão é assegurar o desempenho ético correto e o desempenho ambiental adequado da empresa, melhorar a qualidade de vida de seus funcionários e dependentes, usar o poder e a relação da empresa com seus fornecedores e concorrentes para mobilizá-los a fim de serem socialmente responsáveis (por exemplo: não comprar de nenhum fornecedor que utilize trabalho infantil e escravo). Além disso, deverá implementar normas de respeito 
ao consumidor e mobilizá-lo para atos de solidariedade, podendo utilizar todos os espaços de comunicação para transmitir valores e informações de interesse da comunidade etc.

Sem a pretensão de esgotar todas as abordagens conceituais, mas com o intuito de esclarecer e delimitar as dimensões do conceito de responsabilidade social foram também consultadas as seguintes referências:

Corporate Social Performance (GREENING e TURBAN, 2011) e The evolution of the corporate social performance model (WARTICK e COCHRAN, 1985) que abordam o desempenho social das empresas;

Cidadania Corporativa (MAIGNAN, FERRELL e HULT, 2006) que analisa critérios de cidadania das empresas;

Stakeholder Theory of the Corporation (CLARKSON, 1995), The Stakeholder theory of the corporation: concepts, evidence and implications (DONALDSON e PRESTON, 1995) e Toward a theory of stakeholder identification and salience: defining the principle of who and what really counts (MITCHELL, AGEL e WOOD, 1997) que aborda conceitos ligados a teoria das partes interessadas.

\subsection{A questão ambiental e o desenvolvimento sustentável}

Segundo Mueller (1998), por volta da década de 60, verificou-se um aumento acentuado da poluição no Primeiro Mundo. Em algumas regiões de forte concentração da indústria e de veículos motorizados, a poluição e a degradação ambiental estavam atingindo níveis preocupantes. A conscientização da seriedade desse problema demonstrou que a economia convencional precisava ser adaptada para tratá-lo. No final da década de 70, com o surgimento do movimento ambientalista e o choque da crise do petróleo, fizeram dos recursos naturais um tema de grande importância nas áreas econômica, social e política, que pode ser denominado "Questão Ambiental".

Foi na Comissão Mundial sobre o Meio Ambiente e Desenvolvimento, promovida pela Organização das Nações Unidas (ONU), em 1987, que surgiu uma das mais difundidas definições de desenvolvimento sustentável: 
"O desenvolvimento que procura satisfazer as necessidades da geração atual, sem comprometer a capacidade das gerações futuras de satisfazerem as suas próprias necessidades, significa possibilitar que as pessoas, agora e no futuro, atinjam um nível satisfatório de desenvolvimento social e econômico e de realização humana e cultural, fazendo, ao mesmo tempo, um uso razoável dos recursos da terra e preservando as espécies e os habitats naturais." (CMMAD, 1987).

A TAB.2.1 apresenta os principais eventos relacionados ao desenvolvimento sustentável.

TABELA 2.1- Eventos e fatos importantes do desenvolvimento sustentável

\section{DATA EVENTO FATOS IMPORTANTES}

Estudos científicos sobre a preservação do meio ambiente publicados com o título "Limites do Crescimento" (The Limits to Growth), que venderam mais de 30 milhões de cópias em 30 idiomas.

$1968 \quad$ Clube de Roma Abordavam quatro questões a ser trabalhadas para se alcançar a sustentabilidade:

* controle populacional;

* insuficiência da produção de alimentos;

* redução do crescimento econômico;

* esgotamento dos recursos naturais.

Conferência da Organização das Nações

1972
Unidas (ONU) sobre Meio

Ambiente Humano e

Desenvolvimento

Estocolmo - Suécia
Foram elencados 26 princípios que marcaram o início da busca por uma conciliação entre as práticas de preservação ambiental e o desenvolvimento. 
TABELA 2.1 - Eventos e fatos importantes do desenvolvimento sustentável (continuação)

\section{DATA \\ EVENTO \\ FATOS IMPORTANTES}

1973 Primeira crise do petróleo

Segundo o Departamento de Informação Pública das

Emergência de Nações Unidas, uma organização não

1972 Lideranças Ambientais -

Organização não

governamental, popularmente conhecida como ONG,

se caracteriza por uma união de cidadãos sem fins

Governamental (ONG) lucrativos, cuja atuação pode ser em caráter local, nacional ou até mesmo internacional.

O primeiro choque do petróleo ocorreu quando os países do Oriente Médio descobriram que o petróleo é um bem não renovável e por isso, em algum dia, acabaria. Os produtores então diminuíram a sua produção, elevando o preço do barril de US\$2,90 para US\$11,65 em apenas três meses. As vendas para os EUA e a Europa também foram embargadas nessa época, devido ao apoio dado a Israel na Guerra do Yom Kippur (Dia do Perdão). Com isso, as cotações chegaram a um valor que equivaleria a US\$ 40 nos dias de hoje.

1985 Buraco na camada de
Ozônio

A camada de ozônio estratosférica, que fica de 15 a 35 quilômetros acima da superfície, protege a vida na Terra dos raios solares ultravioleta. O buraco na camada de ozônio se forma quando condições de frio extremo, comuns no inverno da estratosfera da Antártica, reagem com o cloro atmosférico e com resíduos químicos de produção humana destruindo a mesma. O processo de perda de ozônio também acontece em cada inverno no Ártico. No entanto, as condições atmosféricas geralmente mais quentes por lá, limitam a área afetada e o prazo em que as reações químicas ocorrem, resultando em muito menos perda de ozônio no Ártico do que na Antártica. 
TABELA 2.1 - Eventos e fatos importantes do desenvolvimento sustentável (continuação)

DATA

EVENTO

FATOS IMPORTANTES

Comissão Mundial sobre o Meio Ambiente e Desenvolvimento

$1987 \begin{gathered}\text { Desenvolvimento } \\ \text { (CMMAD) da } \\ \text { Organização das Nações }\end{gathered}$ Unidas (ONU) - Noruega
Presidida pela Sra. Gro Harlem Brundtland, primeira ministra da Noruega, elaborou um documento denominado "Nosso Futuro Comum" (Our Common Future), pelo qual os governos se comprometiam a promover o desenvolvimento econômico e social em conformidade com a preservação ambiental. Esse documento ficou também conhecido como "Relatório Brundtland". Nele são apresentados a definição oficial do conceito de Desenvolvimento Sustentável (DS) e os métodos para enfrentar a crise ambiental pela qual o mundo se encaminhava.

$1987 \quad$ Protocolo Montreal

Em 1985, a convenção de Viena para a Proteção da Camada de Ozônio foi assinada por dezenas de países, entre eles o Brasil, um dos primeiros a agir em prol da camada de ozônio. Dois anos depois, foi estabelecido o Protocolo de Montreal sobre as Substâncias que Destroem a Camada de Ozônio (SDO), ligado à Organização das Nações Unidas (ONU). O texto obriga seus signatários a trabalhar para eliminar a produção e o consumo de SDO's. Atualmente, 193 países participam do Protocolo e da Convenção.

Painel Intergovernamental de 1988
Mudanças Climáticas ou Intergovernmental Panel on Climate Change (IPCC)
Órgão criado pelo Programa das Nações Unidas para - Meio Ambiente (PNUMA) e pela Organização Meteorológica Mundial (OMM) em 1988 para estudar o problema das mudanças climáticas. Reuniu 2.500 cientistas de mais de 130 países. A missão desse Painel consistiu em avaliar a informação científica disponível sobre os efeitos das mudanças climáticas, destacar seus impactos ambientais e socioeconômicos e traçar estratégias para dar respostas adequadas ao fenômeno. 
TABELA 2.1 - Eventos e fatos importantes do desenvolvimento sustentável (continuação)

\section{DATA}

1992

sobre Meio Ambiente

Humano e

Desenvolvimento: ECO-

92 ou RIO-92. Rio de

Janeiro - Brasil

\section{FATOS IMPORTANTES}

Com a participação de mais de 178 países, a Agenda 21 é um plano de ação para ser adotado do nível global para o local. Seu alicerce é a sinergia da sustentabilidade ambiental, social e econômica, transcorrendo em todas as suas ações propostas.

Encontro Mundial para o Desenvolvimento Social Copenhagen - Dinamarca
Este foi o primeiro grande encontro internacional sobre o tema do desenvolvimento social. Esse fato está no primeiro parágrafo da Declaração PolíticaProgramática solenemente adotada na ocasião pelos governantes presentes ou representada na capital dinamarquesa nos seguintes termos: "Pela primeira vez na história, a convite das Nações Unidas, nós, Chefes de Estado e de Governo, reunimo-nos para reconhecer a importância do desenvolvimento social e do bem-estar humano de todos e para conferir estes objetivos a mais alta prioridade agora e no século XXI.".
Protocolo de Kyoto Japão
O Protocolo de Kyoto culminou na decisão por consenso de adotar um protocolo para reduzir as emissões de gases de efeito estufa dos países industrializados. O Protocolo de Kyoto foi aberto para assinatura em março do ano seguinte. A adesão ao documento compromete cada país a reduzir suas emissões combinadas de gases de efeito estufa em pelo menos 5\% em relação aos níveis de 1990 até o período entre 2008 e 2012. Esse compromisso, com vinculo legal, promete produzir uma reversão da tendência histórica de crescimento das emissões iniciadas nos países industrializados há cerca de 150 anos. 
TABELA 2.1 - Eventos e fatos importantes do desenvolvimento sustentável (continuação)

\begin{tabular}{|c|c|c|}
\hline DATA & EVENTO & FATOS IMPORTANTES \\
\hline 1999 & $\begin{array}{l}\text { Índice Dow Jones de } \\
\text { Sustentabilidade - DJSI }\end{array}$ & $\begin{array}{l}\text { O DJSI é um índice elaborado pela companhia de } \\
\text { administração de ativos SAM, com sede em Zurique, } \\
\text { para o grupo de índices Dow Jones. Sua } \\
\text { metodologia é baseada na análise de dados } \\
\text { econômicos corporativos, desempenho ambiental e } \\
\text { social, avaliação de questões como governança } \\
\text { corporativa, gestão de risco, mitigação na mudança } \\
\text { climática, padrão para cadeia de abastecimento e } \\
\text { práticas trabalhistas. É utilizado para a análise de } \\
\text { investidores mundiais sócio e ambientalmente } \\
\text { responsáveis. A SAM analisa mais de mil } \\
\text { companhias com ações listadas em bolsa } \\
\text { anualmente. }\end{array}$ \\
\hline 1999 & Global Compact & $\begin{array}{l}\text { O Global Compact é uma iniciativa desenvolvida } \\
\text { pela Organização das Nações Unidas (ONU), com o } \\
\text { objetivo de mobilizar a comunidade empresarial } \\
\text { internacional para a promoção de valores } \\
\text { fundamentais nas áreas de direitos humanos, } \\
\text { trabalho e meio ambiente. Essa iniciativa conta com } \\
\text { a participação das agências das Nações Unidas, } \\
\text { empresas, sindicatos, organizações não } \\
\text { governamentais e demais parceiros necessários } \\
\text { para a construção de um mercado global mais } \\
\text { inclusivo e igualitário. }\end{array}$ \\
\hline 2000 & $\begin{array}{l}\text { Cúpula do Milênio - Nova } \\
\text { York }\end{array}$ & $\begin{array}{l}\text { Organização das Nações Unidas (ONU) reuniu } \\
\text { representantes de } 189 \text { países, chefes de Estado e } \\
\text { de governo, na reunião "Cúpula do Milênio da ONU". } \\
\text { Das discussões e propostas surgiram os "Objetivos } \\
\text { de Desenvolvimento do Milênio até } 2015 " . \text { Nestes } \\
\text { estão incluídas metas dirigidas a áreas prioritárias } \\
\text { que precisariam ser atingidas para melhorar as } \\
\text { condições de saúde, de educação, bem como } \\
\text { eliminar a extrema pobreza, entre outros. }\end{array}$ \\
\hline
\end{tabular}


TABELA 2.1 - Eventos e fatos importantes do desenvolvimento sustentável (continuação)

\begin{tabular}{|c|c|c|}
\hline DATA & EVENTO & FATOS IMPORTANTES \\
\hline 2002 & $\begin{array}{l}\text { Cúpula Mundial sobre } \\
\text { Desenvolvimento } \\
\text { Sustentável - } \\
\text { Johanesburgo - África do } \\
\text { Sul }\end{array}$ & $\begin{array}{l}\text { É reconhecida a complexidade e a dependência de } \\
\text { questões como a pobreza, desperdício, degradação } \\
\text { ambiental e urbana, crescimento populacional, entre } \\
\text { outros. É consenso de que DS é constituído sobre } \\
\text { três pilares dependentes entre si - desenvolvimento } \\
\text { econômico, social e proteção ambiental. É aprovado } \\
\text { o plano de Implementação que estabelece que todos } \\
\text { os estados devem realizar progressos na formulação } \\
\text { e elaboração das estratégias Nacionais de } \\
\text { Desenvolvimento sustentável e iniciar a respectiva } \\
\text { implementação em } 2005 \text {. }\end{array}$ \\
\hline 2004 & $\begin{array}{l}\text { Conferência sobre } \\
\text { Responsabilidade Social } \\
\text { Corporativa - México }\end{array}$ & $\begin{array}{l}\text { Conferência interamericana sobre responsabilidade } \\
\text { social corporativa para examinar a ideia de que as } \\
\text { empresas que ganham lucros financeiros também } \\
\text { devem usar práticas de negócios que beneficiem a } \\
\text { sociedade como um todo. }\end{array}$ \\
\hline 2006 & $\begin{array}{l}\text { Responsabilidade Social } \\
\text { Corporativa Foco da } \\
\text { Conferência Brasil - Brasil }\end{array}$ & $\begin{array}{l}\text { Conferência que ocorreu em dezembro na cidade } \\
\text { brasileira de Salvador, com a presença de várias } \\
\text { autoridades norte-americanas entre os seus } 500 \\
\text { participantes de } 20 \text { países. A conferência foi } \\
\text { patrocinada pelo Banco Interamericano de } \\
\text { Desenvolvimento (BID), a organização não } \\
\text { governamental com sede no Brasil chamado o } \\
\text { Instituto Ethos da Federação das Indústrias do } \\
\text { estado brasileiro da Bahia. }\end{array}$ \\
\hline
\end{tabular}


TABELA 2.1 - Eventos e fatos importantes do desenvolvimento sustentável (continuação)

\begin{tabular}{|c|c|c|}
\hline DATA & EVENTO & FATOS IMPORTANTES \\
\hline 2010 & $\begin{array}{l}\text { Conferência Internacional } \\
\text { sobre Responsabilidade } \\
\text { Social das Empresas - } \\
\text { Brasil }\end{array}$ & $\begin{array}{l}\text { Organizada pela Representação da Comissão } \\
\text { Europeia em Portugal, no quadro do Ano Europeu do } \\
\text { Combate à Pobreza e Exclusão Social, em parceria } \\
\text { com a Coordenação Nacional do Ano Europeu, a } \\
\text { AIP/Associação Industrial Portuguesa, a } \\
\text { CITE/Comissão para a Igualdade no Trabalho e no } \\
\text { Emprego, o ISEG - Instituto de Economia e Gestão } \\
\text { da Universidade Técnica de Lisboa e a Faculdade de } \\
\text { Economia da Universidade Nova de Lisboa. }\end{array}$ \\
\hline 2012 & $\begin{array}{l}\text { Conferência da } \\
\text { Organização das Nações } \\
\text { Unidas(ONU) sobre } \\
\text { Desenvolvimento } \\
\text { Sustentável: Rio+20. Rio } \\
\text { de Janeiro }\end{array}$ & $\begin{array}{l}\text { A Rio+20 foi assim conhecida porque marcou os } \\
\text { vinte anos de realização da Conferência das Nações } \\
\text { Unidas sobre Meio Ambiente e Desenvolvimento } \\
\text { (Rio-92) e contribuiu para definir a agenda do } \\
\text { desenvolvimento sustentável para as próximas } \\
\text { décadas. O objetivo da Conferência foi a renovação } \\
\text { do compromisso político com o desenvolvimento } \\
\text { sustentável, por meio da avaliação do progresso e } \\
\text { das lacunas na implementação das decisões } \\
\text { adotadas pelas principais cúpulas sobre o assunto e } \\
\text { do tratamento de temas novos e emergentes. }\end{array}$ \\
\hline
\end{tabular}

Fonte: (LIMA, 2012), (Declaração da Conferência das Nações Unidas Sobre o Meio Ambiente Humano, 1972), (Organizações Não Governamentais, 2011), (O primeiro choque do petróleo, 2000), (REUTERS, 2012), (CMMAD, 1987), (Convenção de Viena e Protocolo de Montreal, 2012), (IPCC - Painel Intergovernamental sobre Mudança do Clima, 2002), (CNUMAD, 1995) (CAMPOS, 1995), (ALVES, 1997), (CONVENÇÃO QUADRO DAS NAÇÕES UNIDAS SOBRE MUDANÇA DO CLIMA, 1998), (CHAVES, 2010), (Global Compact, 2003), (CÚPULA MUNDIAL SOBRE DESENVOLVIMENTO SUSTENTÁVEL , 2002), (Rio + 20, 2012), (LAURENTI, 2005), (Mexico City to Host Conference on Corporate Social Responsibility, 2004), (Corporate Social Responsibility Focus of Brazil Conference, 2006), (Conferência Internacional sobre Responsabilidade Social das Empresas, 2010). Adaptado pela autora.

O conceito de responsabilidade social passou a fazer parte do conceito de desenvolvimento sustentável, especificamente dentro da dimensão social que, em conjunto com as dimensões econômica e ambiental, constituem os "pilares" do desenvolvimento sustentável (FROES e MELLO NETO, 1999). 


\subsection{Histórico da atuação social no Brasil}

Segundo Reis (2007), o histórico da atuação do setor privado brasileiro no contexto da RS tem registro desde 1961, quando a gravidade dos problemas sociais do país começou a preocupar alguns dirigentes cristãos de empresas brasileiras, que se uniram para fundar a Associação dos Dirigentes Cristãos de Empresas (ADCE). Em 1977, a Associação se consolidou como uma entidade que, à luz do pensamento social-cristão, congregava empresários comprometidos com a transformação de suas empresas em um ambiente de melhoria pessoal a fim de contribuir para uma sociedade solidária, justa, livre e humana. A ADCE foi pioneira no lançamento do debate sobre o Balanço Social, embora sua publicação só tenha iniciado em 1984, com a empresa Nitrofértil, seguida, em 1992, pelo balanço do Banco do Estado de São Paulo (Banespa).

A Câmara Americana de Comércio de São Paulo, em 1982, instituiu o Prêmio ECO Empresa e Comunidade em cinco categorias: cultura, educação, participação comunitária, educação ambiental e saúde. A finalidade dessa iniciativa foi reconhecer e divulgar esforços realizados por empresas que desenvolvessem projetos sociais para a promoção da cidadania. Em 1986, a Fundação Instituto de Desenvolvimento Empresarial e Social (FIDES) reuniu empresários de São Paulo, Minas Gerais, Bahia e Rio Grande do Sul para debates, eventos e atividades, em níveis nacional e internacional, sobre a responsabilidade social das empresas, com a missão de promover o diálogo e o entendimento em prol do desenvolvimento humano, entre as várias instâncias que compunham a sociedade (REIS, 2007).

Essas iniciativas das empresas com fins sociais suscitaram questionamentos e reflexões sobre a abrangência e a competência do Segundo e do Terceiro Setor ${ }^{6}$ em face da área social: "Um terceiro setor, não lucrativo e não governamental, coexiste hoje, no interior de cada sociedade, com o setor público estatal e com o setor privado empresarial." (FERNANDES, 1994).

É importante destacar que se trata de um debate em curso, portanto, inconclusivo no que se refere às definições das respectivas competências. Para

\footnotetext{
${ }^{6} \mathrm{O}$ primeiro setor é o governo, que é responsável pelas questões sociais. O segundo setor é o privado, responsável pelas questões individuais. Com a falência do Estado, o setor privado começou a ajudar nas questões sociais, por meio das inúmeras instituições que compõem o chamado terceiro setor (KANITZ, 2012).
} 
financiar sua atuação, o Terceiro Setor utiliza recursos provenientes de pessoas físicas e jurídicas para produzir bens e serviços públicos que respondam às necessidades coletivas sem gerar lucros, colocando em destaque inúmeras ações de indivíduos, grupos, instituições e, consequentemente, de empresas. O objetivo de tais práticas é suprir carências sociais que afetam grande parcela da população (REIS, 2007).

Em São Paulo, em 1989, um grupo de empresários em parceria com a Câmara de Comércio de São Paulo e com outros agentes da sociedade, que já vinham discutindo e trocando experiências sobre ações que contribuíssem para diminuir as desigualdades sociais do país, deu origem a um subcomitê de filantropia. Essa ação resultou, em 1985, na criação do Grupo de Instituições, Fundações e Empresas (GIFE) ${ }^{7}$ composto por instituições de origem privada. $O$ objetivo do GIFE era instrumentalizar e qualificar tecnicamente as empresas, as fundações empresariais e os indivíduos que quisessem realizar investimentos sociais. Isso foi feito por meio da difusão de conceitos e práticas de gestão que aperfeiçoassem os recursos aplicados no desenvolvimento de ações de bemestar e projetos sociais (GIFE, 2002).

A partir de um maior planejamento e monitoramento dos recursos doados, foi possível reverter as contribuições em reais benefícios à sociedade e às próprias empresas, mediante a otimização dessas doações. $O$ investimento social privado ainda é protagonizado pelos institutos ${ }^{8}$ ou fundações ${ }^{9}$ de origem empresarial, fundações comunitárias e familiares, todas constituídas como pessoa jurídica. As doações podem, inclusive, ser passíveis de deduções de incentivos fiscais. O Governo Federal autoriza as empresas tributadas em regime de lucro

\footnotetext{
7 "Em 1995, quando um grupo de trabalho sobre 'cidadania empresarial', organizado em torno da Câmara de Comércio Brasil-EUA em São Paulo (Amcham), formalizou-se como Grupo de Instituições, Fundações e Empresas (GIFE), o termo 'terceiro setor' passou a ganhar notoriedade" (FALCONER e VILELA, 2001).

8 "No plano legal, os institutos empresariais correspondem às personalidades jurídicas denominadas associações, que são entidades criadas, necessariamente, a partir de ideias e esforços de mais de uma pessoa, em torno de um propósito que não tenha finalidade lucrativa" (GIFE, 2002).

9 "As fundações empresariais são instituídas pelos sócios da empresa ou empresas envolvidas, ou por seus representantes legais, que fazem uma doação de bens do patrimônio de suas corporações para servir a uma causa predefinida" (GIFE, 2002).
} 
real a deduzirem até $2 \%$ do lucro operacional bruto em doações, desde que destinadas a entidades sem fins lucrativos, pela Lei das Organizações da Sociedade Civil de Interesse Público (OSCIP), ํo 9.790/1999, ou a entidades declaradas como de utilidade pública, pela Lei oㅜ 35/1991 (GIFE, 2002).

Outro destaque do meio empresarial brasileiro é a Associação Brasileira dos Fabricantes de Brinquedos (ABRINQ) pela iniciativa pelos Direitos da Criança e do Adolescente. Fundada em 1990, a ABRINQ é uma entidade de utilidade pública federal, mantida também por recursos de empresas, dentre outros, e não tem fins lucrativos. Sua missão é promover a defesa dos direitos e o exercício da cidadania das crianças e dos adolescentes, mobilizando e articulando a sociedade civil e o poder público, com atuação pautada pela ONU, pela Constituição Federal do Brasil de 1988 e pelo Estatuto da Criança e Adolescente (ECA) de 1990. A ABRINQ apoia vários projetos, dentre eles o Programa Empresa Amiga da Criança e o Selo Empresa Amiga da Criança, iniciativas que buscam engajar empresas em uma atuação social, em especial, na prevenção e erradicação do trabalho infantil (REIS, 2007).

A partir de 1993, outras empresas passaram a publicar o Balanço Social, mas este obteve maior visibilidade nacional somente em 1997, por meio de uma parceria com o Instituto Brasileiro de Análises Sociais e Econômicas (Ibase). Criado em 1981 pelo Sociólogo Herbert de Souza, o Ibase é uma organização não governamental sem fins lucrativos que, em parceria com o jornal Gazeta Mercantil, lançou o Selo do Balanço Social. O Ibase foi um marco no Terceiro Setor, pois lançou a Campanha Ação da Cidadania contra a Miséria e pela Vida, que mobilizou todo o país contra a fome que assolava uma grande parcela de sua população em 1993 (REIS, 2007).

Ultimamente, o Balanço Social já é utilizado por muitas empresas em vários Estados do Brasil. Regulamentado pelo Projeto de Lei no 3.116/1997, o Balanço Social tem caráter obrigatório para empresas privadas com mais de 100 funcionários na cidade de São Paulo. No entanto, a obrigatoriedade de apresentação do Balanço Social é questionável, uma vez que geralmente não é realizada por uma mudança de cultura e postura empresarial socialmente responsável, mas por uma obrigação expressa por lei, ainda que possa 
representar um primeiro exercício no processo de sensibilização e conscientização das empresas a favor da área social (REIS, 2007).

Em 1994, foi fundado o Instituto Ayrton Senna, uma organização não governamental de origem empresarial cujo objetivo é oferecer condições de desenvolvimento humano a crianças e jovens do Brasil. Em parceria com o poder público e o setor privado, esse instituto tem promovido o desenvolvimento pleno do potencial de cidadãos por meio da criação, implementação e disseminação de técnicas e instrumentos de atuação social, denominados tecnologias sociais. Os recursos provêm de alianças estratégicas com empresas e do licenciamento da marca e da imagem de Ayrton Senna, como o Senninha (REIS, 2007).

O contexto de iniciativas empresariais e governamentais descrito, quer por meio da criação de ONGs, quer pelo desenvolvimento e apoio a projetos sociais próprios ou junto às comunidades, indica um movimento, uma mobilização e uma atuação social dos três setores da economia, que têm promovido ações na tentativa de minimizar problemas de ordem social. Compreender o conceito da responsabilidade social das empresas possibilita resgatar sua amplitude e sua essência, baseadas em valores éticos e universais mais amplos, além de indicativos de compromisso social que no Brasil, está sendo tratado pelo Instituto Ethos $^{10}$ de Responsabilidade Social (REIS, 2007).

Criado em 1998, o Instituto Ethos é uma associação de empresas interessadas em desenvolver suas atividades de forma socialmente responsável. Está em permanente processo de avaliação e aperfeiçoamento, por meio do desenvolvimento de atividades de informação, conferências, debates e encontros, assistência técnica, comunicação, articulação e mobilização. A missão do Ethos é disseminar a prática da responsabilidade social empresarial, ajudando as empresas a compreender e a incorporar o conceito do comportamento socialmente responsável, além de implementar políticas e práticas que atendam a elevados critérios éticos. O Ethos tem demonstrado aos acionistas a relevância de um comportamento socialmente responsável para atingir o desenvolvimento

\footnotetext{
${ }^{10}$ Ethos, palavra grega que significa estudo dos costumes, do caráter, da ciência da moral, do "espírito" de uma época, o tom determinante do sentimento de um povo ou de uma comunidade. De ethos deriva a ética como ciência do dever humano em seu sentido mais amplo, conjunto de regras de conduta do convívio entre as pessoas (INSTITUTO ETHOS, 2011).
} 
sustentável. Para alcançar o retorno dos investimentos realizados em longo prazo, os acionistas deverão:

assumir responsabilidades com todos aqueles que são impactados por suas atividades;

* identificar formas inovadoras e eficazes de atuar em parceria com as comunidades na construção do bem-estar comum;

prosperar, contribuindo para o desenvolvimento social, econômico e ambientalmente sustentável (REIS, 2007).

Tão importante quanto estudar as diversas definições da responsabilidade social, é também importante estudar as diversas metodologias e indicadores que mensuram a responsabilidade social. Algumas metodologias e indicadores da responsabilidade social serão discutidos a seguir a fim de fundamentar 0 desenvolvimento desse trabalho. 


\section{FUNDAMENTAÇÃO TEÓRICA}

A seguir são apresentadas algumas das metodologias e indicadores de mensuração da responsabilidade social encontrados na literatura e será apresentada uma análise comparativa entre estas metodologias. Serão apresentadas também normas e certificações que não se resumem apenas em padronização de procedimentos, mas que são ferramentas de gestão para garantir o planejamento da evolução sustentável.

\subsection{Metodologias e indicadores da responsabilidade social}

Mensurar a responsabilidade social é imprescindível para inseri-la no processo de decisão de todos os níveis organizacionais. Essa mensuração pode ser feita por meio de índices ou conjunto de indicadores. Independentemente do tipo de mensuração utilizado, suas funções serão as mesmas e estão ligadas ao embasamento para a tomada de decisão, que envolve:

auxiliar os tomadores de decisão na avaliação do desempenho em relação aos objetivos do desenvolvimento sustentável a fim de fornecer um embasamento para o planejamento de ações futuras (BELLEN, 2005; MOLDAN e BILHARZ, 1997; GALLOPÍN, 1997; COMISSION ON SUSTAINABLE DEVELOPMENT, 2007; MCCOLL e STANKEY , 2004);

tornar mais claro uma tendência ou fenômeno que não foi detectado em um primeiro momento, antecipando futuras condições e tendências (MOLDAN e BILHARZ, 1997; GALLOPÍN, 1997; MCCOLL e STANKEY, 2004);

quantificar, medir, sumarizar, simplificar, comparar e comunicar informações relevantes para a tomada de decisão (KRAJNC e GLAVIC, 2003; MOLDAN e BILHARZ, 1997; GALLOPÍN, 1997; COMISSION ON SUSTAINABLE DEVELOPMENT, 2007); 
auxiliar os tomadores de decisão na compreensão do significado operacional do conceito de desenvolvimento sustentável funcionando como ferramenta educacional (BELLEN, 2005).

Um número significativo de metodologias e indicadores para mensuração da responsabilidade social em nível nacional e internacional têm sido desenvolvidos. Já no âmbito organizacional, houve um menor número de iniciativas, construindo-se mais guias ou orientações para divulgação de ações corporativas relacionadas à sustentabilidade e responsabilidade social, do que sistemas de mensuração para a tomada de decisão (DELAI e TAKAHASHI, 2008).

Alguns exemplos dessas iniciativas e modelos de mensuração são: o Global Reporting Initiative (GRI), as Métricas de Sustentabilidade do IChemE, o Índice Dow Jones de Sustentabilidade, o Guia para Empresas Multinacionais da Organization for Economic Cooperation and Development (OECD), o Manual para Elaboração de Projetos Socioambientais, Metodologia Tear, Global Compact e os Indicadores Ethos de Responsabilidade Social e Empresarial.

Para o desenvolvimento desse trabalho, foram utilizadas como base, onze iniciativas de mensuração da sustentabilidade e da responsabilidade social. Essas iniciativas têm foco nacional e empresarial, apresentam um número significativo de dimensões e indicadores que compreendem as principais dimensões da sustentabilidade e da responsabilidade social, sendo largamente utilizadas e referenciadas na teoria de mensuração da responsabilidade social.

As iniciativas selecionadas e suas descrições serão apresentadas a seguir de forma sintética.

\subsubsection{Indicadores de Desenvolvimento Sustentável da Organização das Nações Unidas (IDS)}

Este conjunto de indicadores foi desenvolvido pela Comissão para Desenvolvimento Sustentável da Organização das Nações Unidas em 1995. Seu principal objetivo é tornar os indicadores de desenvolvimento sustentável acessíveis aos tomadores de decisão, por meio da sua definição e explicação de suas metodologias, bem como no treinamento para sua utilização (COMISSION ON SUSTAINABLE DEVELOPMENT, 2007). 
Estes indicadores tem uma abrangência nacional e segue o conceito de desenvolvimento sustentável proposto pelo Relatório Brundtland, que aborda quatro dimensões da sustentabilidade: a social, a ambiental, a econômica e a institucional. A FIG. 3.1 abaixo representa um quadro contendo estes indicadores.

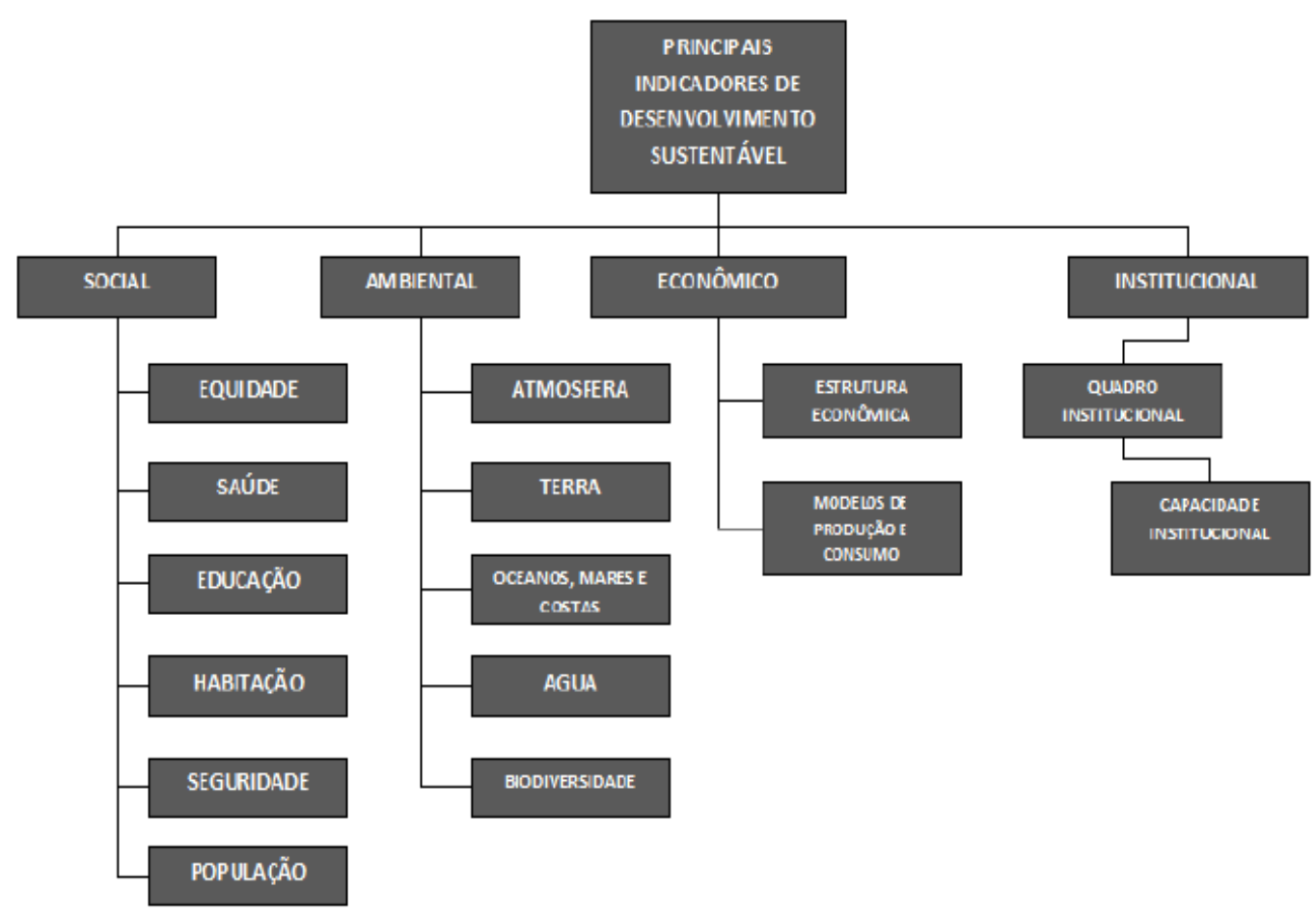

Fonte: (LABUSCHAGNE, BRENT e VAN ERCK, 2005)

FIGURA 3.1 - Quadro da Comissão das Nações Unidas sobre o Desenvolvimento Sustentável

\subsubsection{Dashboard de Sustentabilidade}

Este indicador foi desenvolvido em 1998 pelo Consultative Group for Sustainable Development Indicators e foi considerada uma das três mais importantes iniciativas de mensuração da sustentabilidade, de acordo com pesquisa realizada por especialistas internacionais (BELLEN, 2005).

O Dashboard é uma ferramenta on-line criada para ser compreendida por especialistas, pela mídia, por gestores, por políticos e o público em geral. Usa a imagem universalmente conhecida de um painel de instrumentos, que apresenta quatro mostradores representando o desempenho econômico, ambiental e social. Cada disco é um agregado de vários indicadores (taxa de emprego, a cobertura florestal e do nível de alfabetização, por exemplo), exibido como cunhas 
coloridas. Tons de verde indicam condições mais positivas ou sustentáveis, o amarelo é neutro e o vermelho é um aviso urgente de não sustentabilidade em uma área (FIG 3.2). O efeito é um indicador de fácil compreensão de um desenvolvimento sustentável do país e possibilitar a comparação com outros países. A sua principal vantagem é mostrar tanto um índice de desempenho global do país, quanto os sub-indices para cada dimensão e seus temas, facilitando assim a identificação dos pontos a serem aprimorados (HARDI e ZDAN, 2000).

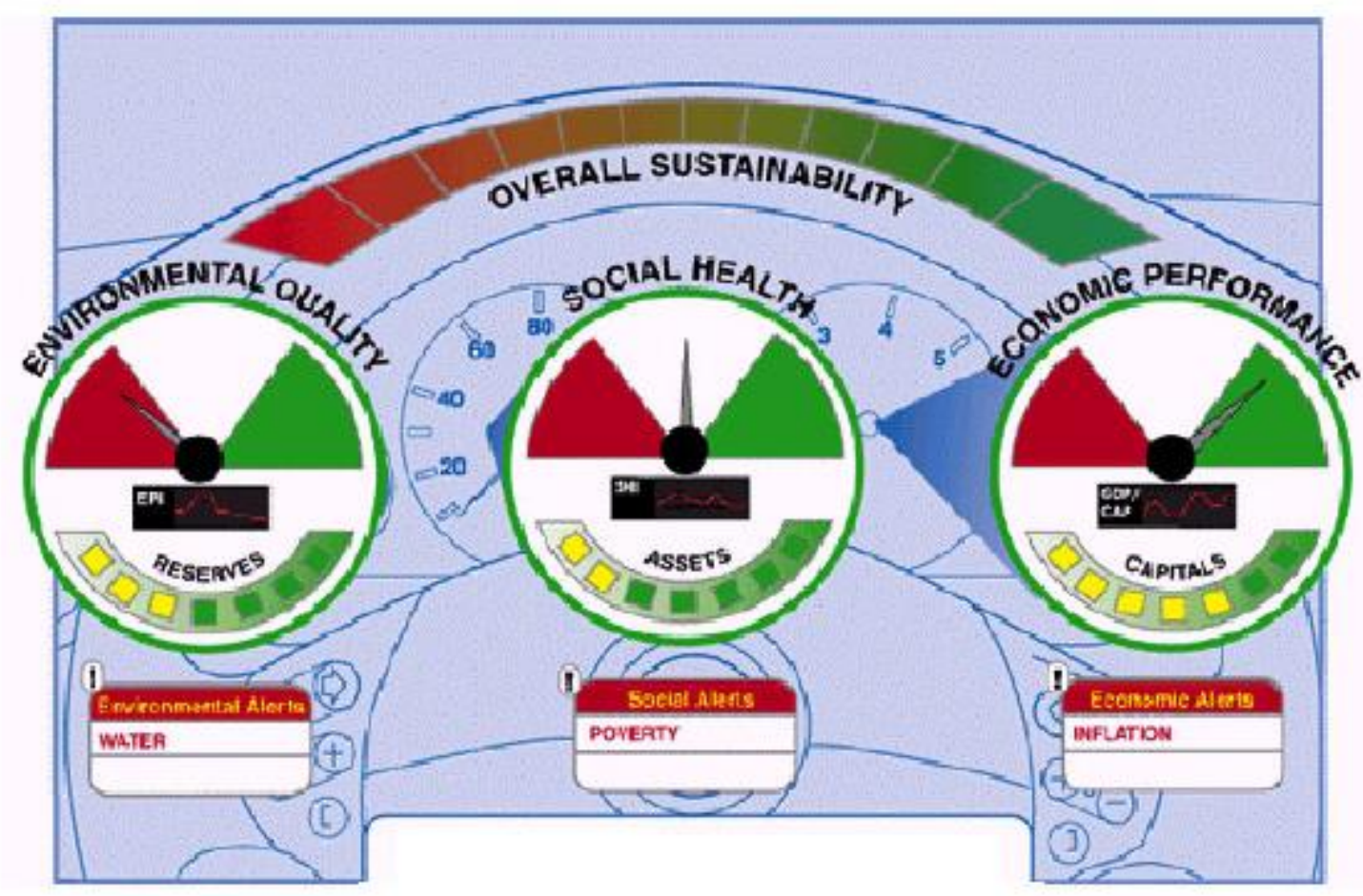

Fonte: (HARDI e ZDAN, 2000)

FIGURA 3.2 - Dashboard of Sustainability

\subsubsection{Barômetro de Sustentabilidade}

Este é um índice desenvolvido pelo Instituto Mundial de Conservação que mensura a sustentabilidade nos níveis local, regional e nacional por meio de uma escala de desempenho dada duas dimensões: bem-estar humano e bem-estar do ecossistema. De forma similar ao Dashboard, foi considerado também uma das três mais importantes iniciativas de mensuração da sustentabilidade (BELLEN, 2005). 
O Barômetro de Sustentabilidade é definido por Prescott (1997) como uma ferramenta para medir e comunicar para a sociedade o bem-estar e o progresso em direção ao desenvolvimento sustentável. Ela fornece um meio sistemático de organizar e combinar indicadores de maneira que os usuários possam chegar a conclusões sobre as condições das pessoas, dos ecossistemas e dos efeitos da interação entre estas duas esferas. O sistema apresenta estas conclusões visualmente, fornecendo aos atores interessados um retrato do bem-estar humano e ecológico. Essa ferramenta considera a sustentabilidade como o balanço entre o bem-estar humano por meio dos indicadores (saúde, população, riqueza, conhecimento, cultura, comunidade e equidade) e o do ecossistema, com base nos indicadores (terra, água, ar, espécies e utilização de recursos).

Para calcular ou medir o progresso em direção à sustentabilidade os valores para os índices de bem-estar social e da ecosfera são calculados, bem como os dos sub índices, caso existam. O índice de bem-estar do ecossistema identifica tendências da função ecológica no tempo. É uma função da água, terra, ar, biodiversidade e utilização dos recursos. O índice de bem-estar humano representa o nível geral de bem-estar da sociedade e é uma função do bem-estar individual, saúde, educação, desemprego, pobreza, rendimentos, crime, bem como negócios e atividades humanas. O objetivo da ferramenta é avaliar conjuntamente os principais componentes da sustentabilidade. Trata-se de um gráfico bidimensional onde os estados do bem-estar humano e do ecossistema são colocados em escalas relativas, que vão de 0 a 100, indicando uma situação de ruim até boa em relação à sustentabilidade. A localização do ponto definido por estes dois eixos, dentro do gráfico bidimensional, fornece uma medida de sustentabilidade ou insustentabilidade do sistema. A representação gráfica desta ferramenta pode ser visualizada na FIG. 3.3 (PRESTCOTT-ALLEN, 1997).

A escala utilizada para cada um dos eixos varia de zero a cem. Esta dividida em cinco setores de 20 pontos cada um. Cada setor corresponde a uma cor, que varia do vermelho até o verde: péssimo (vermelho de 0-20); ruim (rosa de 21 a 40); médio (amarelo de 41 a 60); bom (azul de 61 a 80) e ótimo (verde de 81 a 100). 


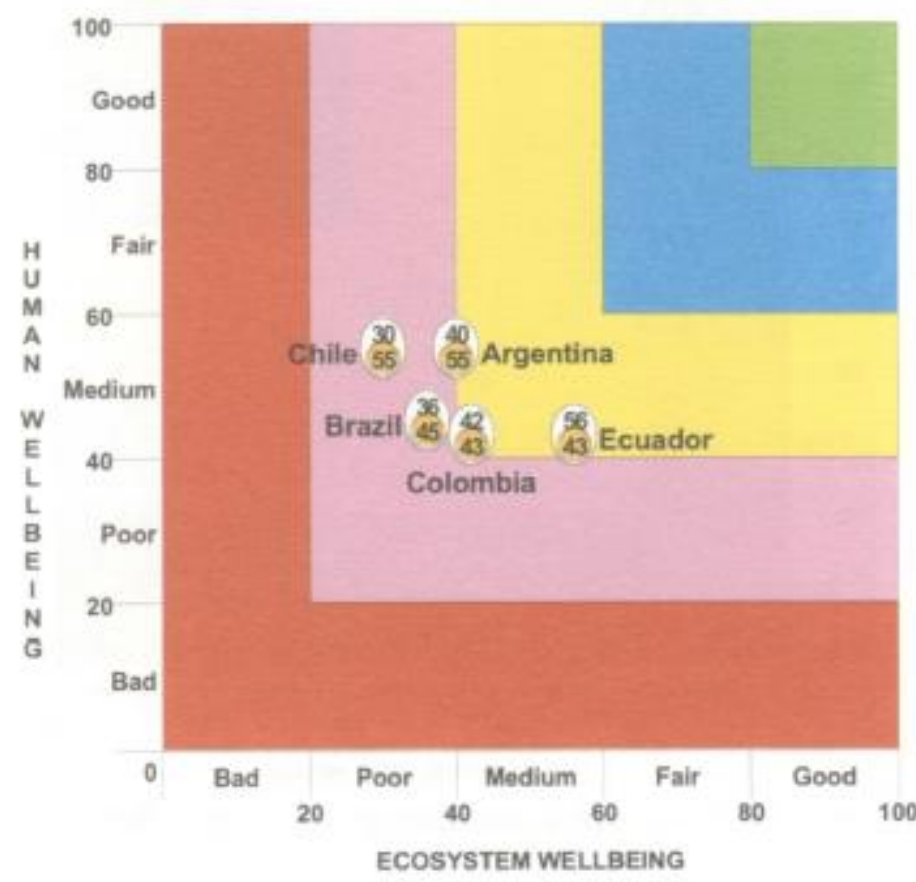

Fonte: (PRESTCOTT-ALLEN, 1997)

FIGURA 3.3 - Barometer of Sustainability

\subsubsection{Global Reporting Initiative (GRI)}

Este é um guia para a elaboração de relatórios de sustentabilidade lançado em 1997 pela organização não governamental americana Coalition for Environmentally Responsible Economies (CERES) e pela United Nations Environment Programme (UNEP). Ele tem por objetivo auxiliar as empresas e suas partes interessadas no entendimento e comunicação das contribuições da organização para o alcance do desenvolvimento sustentável, melhorando a qualidade e utilidade dos relatórios de sustentabilidade. Tem como foco estabelecer o equilíbrio entre as necessidades econômicas, ambientais e sociais que não comprometa o resultado futuro (GLOBAL REPORTING INITIATIVE, 2013). A FIG. 3.4 apresenta a hierarquia de seus indicadores.

Existem alguns princípios que devem ser seguidos para a elaboração dos relatórios do $\mathrm{GRI}$ :

O princípio da materialidade, onde as informações no relatório devem cobrir temas e indicadores que reflitam os impactos econômicos, ambientais e sociais significativos da organização ou possam influenciar de forma substancial as avaliações e decisões dos stakeholders; 
Inclusão dos stakeholders onde a organização relatora deve identificar seus stakeholders e explicar no relatório que medidas foram tomadas em resposta a seus interesses e expectativas procedentes;

Contexto da sustentabilidade onde o relatório deverá apresentar 0 desempenho da organização no contexto mais amplo da sustentabilidade;

Abrangência com a cobertura dos temas e indicadores relevantes, assim como a definição do limite do relatório, deverá ser suficiente para refletir os impactos econômicos, ambientais e sociais significativos e permitir que os stakeholders avaliem o desempenho da organização no período analisado (GLOBAL REPORTING INITIATIVE, 2013).

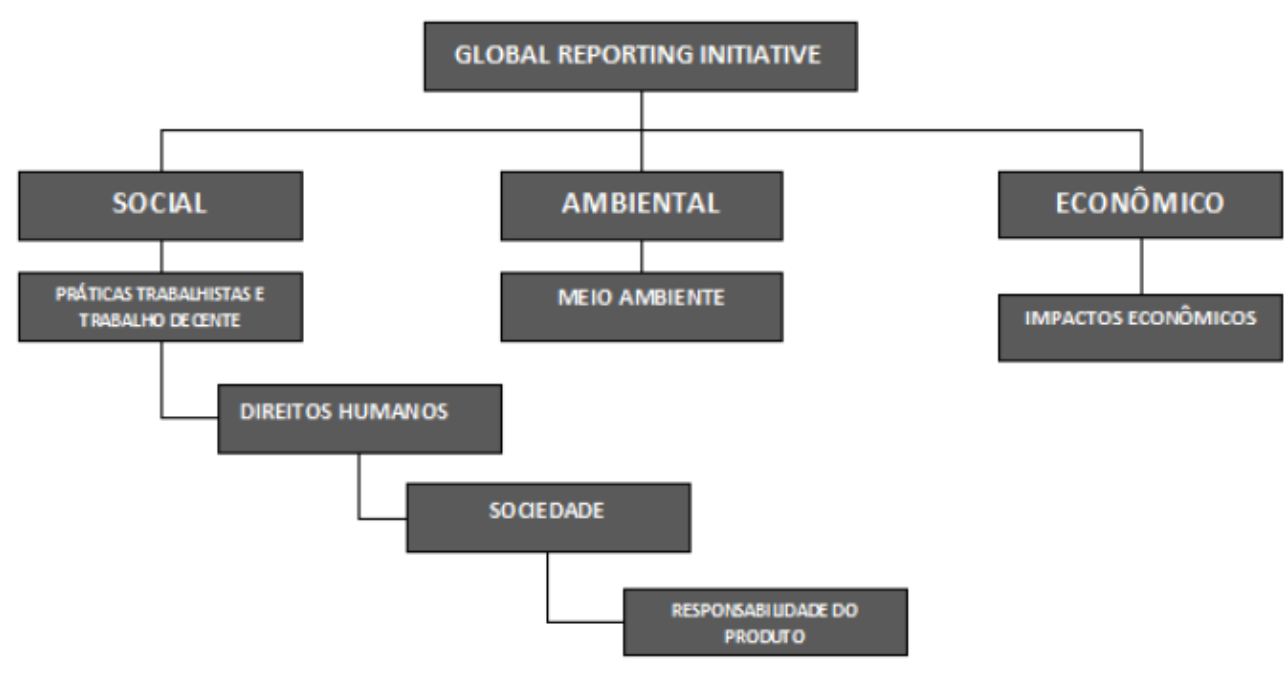

Fonte: (GLOBAL REPORTING INITIATIVE, 2013)

FIGURA 3.4 - Estrutura Hierárquica do Global Report Initiative

É interessante ressaltar que a Eletronuclear ${ }^{11}$ apresenta anualmente um Relatório de Sustentabilidade que é disponibilizado nos moldes da GRI. O relatório é resultado das atividades do Comitê de Sustentabilidade Empresarial da Eletrobras Eletronuclear criado em 2007, por orientação da Holding Eletrobras e consolida as informações obtidas de todas as unidades organizacionais dessa empresa, de forma clara e transparente, evidenciando o compromisso com os

\footnotetext{
${ }^{11}$ A Eletrobras Eletronuclear foi criada em 1997 com a finalidade de operar e construir usinas termonucleares no Brasil. Subsidiária da Eletrobras, a Eletronuclear é uma empresa de economia mista e responde pela geração de aproximadamente $3 \%$ da energia elétrica consumida no Brasil. Pelo sistema elétrico interligado, essa energia chega aos principais centros consumidores do país e corresponde, por exemplo, a mais de 30\% da eletricidade consumida no Estado do Rio de Janeiro (A Eletrobras Eletronuclear, 2013).
} 
princípios da sustentabilidade e com os valores que norteiam suas práticas (COMITÊ DE SUSTENTABILIDADE EMPRESARIAL, 2013).

\subsection{5 Índice Triple Bottom Line (TBL)}

O Triple Bottom Line ou modelo dos Três Resultados Líquidos utiliza três dimensões da sustentabilidade: as dimensões econômica, social e ambiental.

A dimensão econômica envolve a obtenção de resultados para os acionistas, como: lucratividade, crescimento, valorização das ações, redução de riscos, entre outros. Além disso, beneficia a sociedade: gerando empregos, arrecadando impostos, evitando os custos sociais pela internalização de problemas ambientais e tendo práticas leais de concorrência.

Entre as ações típicas da dimensão ambiental estão as reduções de materiais e energia por unidade produzida, reduções das emissões de poluentes, substituição de componentes tóxicos, reuso e recuperação de materiais.

A dimensão social, por sua vez, trata: da não discriminação no trabalho, do combate à corrupção, da valorização dos direitos humanos e das políticas de beneficio.

Essas dimensões frequentemente se sobrepõem. Por exemplo, a seleção de fornecedores de materiais e serviços, tipicamente uma atividade econômica, pode também ser um componente das dimensões sociais e ambientais, quando a empresa é premiada devido a suas práticas sustentáveis (WANG, 2005).

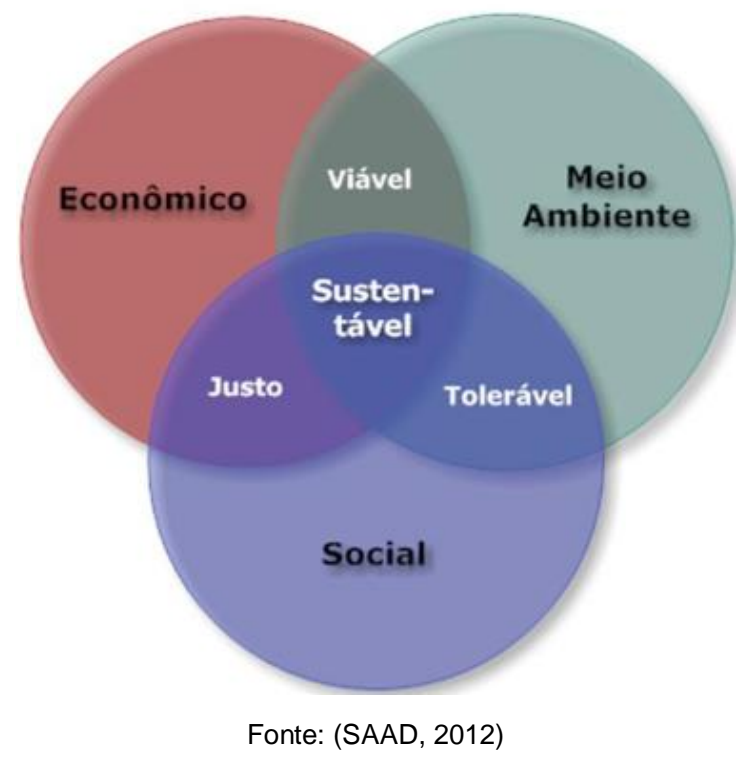

FIGURA 3.5 - Triple Bottom Line 


\subsubsection{Métricas de sustentabilidade da Instituição dos Engenheiros Químicos da Inglaterra (IChemE)}

É um conjunto de indicadores com ênfase na mensuração da sustentabilidade das indústrias, desenvolvido pela Instituição dos Químicos da Inglaterra. Utiliza o conceito TBL anteriormente abordado: "equilíbrio da responsabilidade ambiental, retorno econômico (geração de riqueza) e desenvolvimento social." Estes indicadores estão apresentados na FIG 3.6 (INSTITUTION OF CHEMICAL ENGINEERS, 2002).

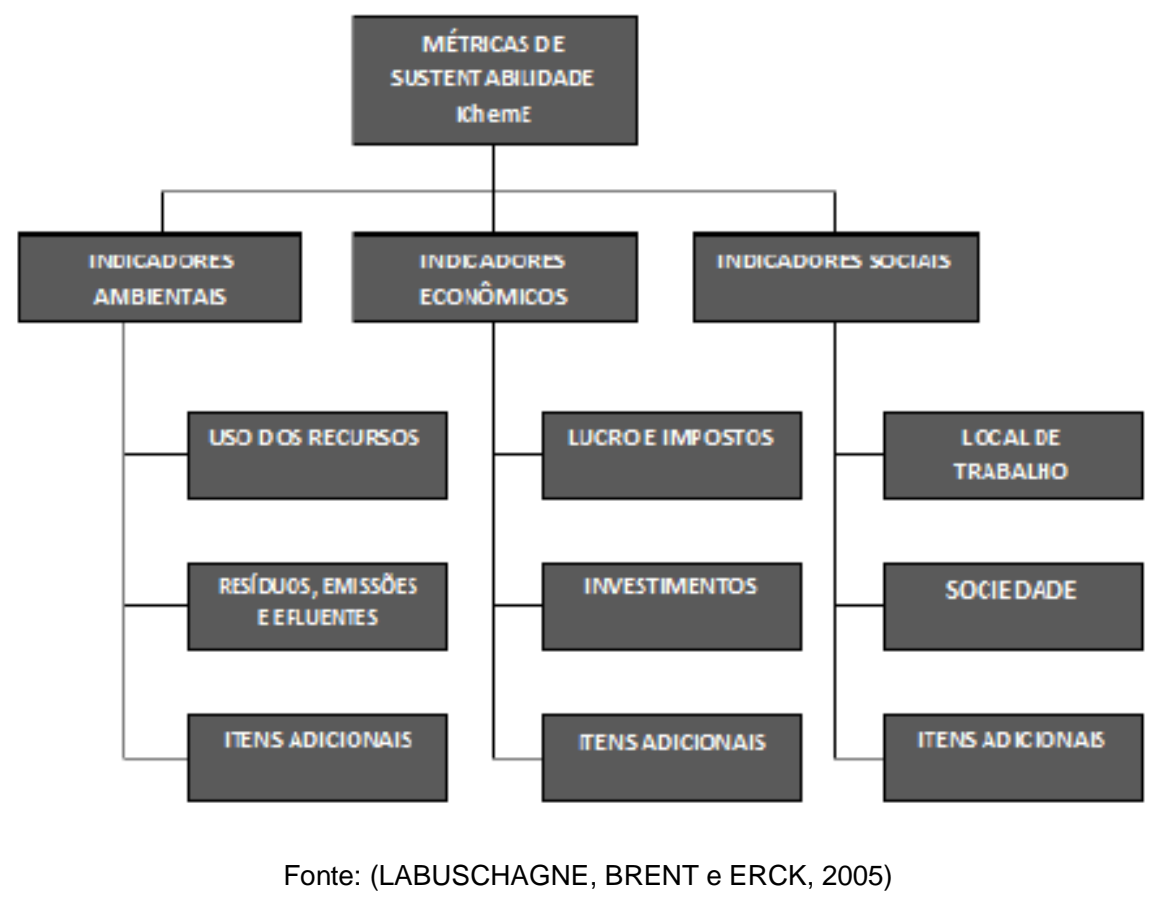

FIGURA 3.6 - Métricas de sustentabilidade da Instituição de Engenheiros Químicos (IchemE)

\subsubsection{Dow Jones Sustainability Index (DJSI)}

O DJSI foi estabelecido em 1999 e avalia o desempenho das empresas líderes mundiais em sustentabilidade selecionadas dentre as 2.500 maiores empresas globais. É constituído a partir de um questionário com 33 diferentes critérios, além dos documentos e informações fornecidos pelas empresas aos analistas, à imprensa e as partes interessadas. Esse índice define sustentabilidade como "criar valor de longo prazo aos acionistas por meio do aproveitamento das oportunidades e do gerenciamento dos riscos derivados dos 
desenvolvimentos econômico, social e ambiental." (DOW JONES INDEXES, 2013).

Um conjunto definido de critérios FIG. 3.7 é utilizado para avaliar as oportunidades e os riscos decorrentes da evolução econômica, ambiental e social para o universo elegível de empresas.

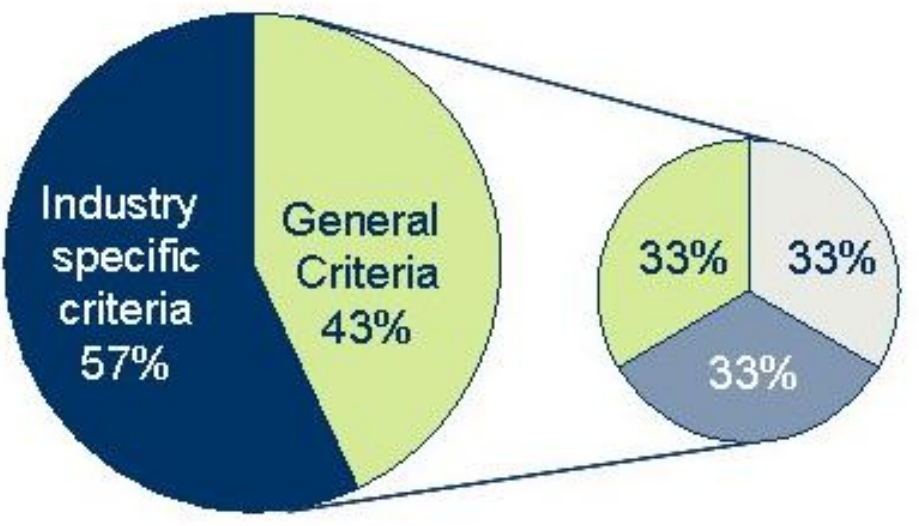

Economic Erwironmental 1 Social
Economic Dimension

- Corporate Governance

- Code of Conduct, Compliance

- Risk \& Crisis Management

- Customer Relationship Mgmt

- Innovation Management

Environmental Dimension

- Environmental Mgmt System

- Environmental Performance

- Climate Strategy

- Product Stewardship

- Biodiversity

Social Dimension

- Human Capital Development

- Talent Attraction \& Retention

- Occupational Health \& Safety

- Stakeholder Engagement

- Social Reporting

Fonte: (Corporate Sustainability Assessment, 2013)

FIGURA 3.7 - Summary of Dow Jones Sustainability Indexes

\subsubsection{Metodologia Tear}

A Metodologia Tear foi criada em parceria com a consultoria Business Sustainability Development $\left(\mathrm{BSD}^{12}\right)$, considerando a experiência de seis grandes empresas que já trabalhavam com a implantação da RSE em sua cadeia de fornecedores. São elas: ABN Amro Real, ArcelorMittal Brasil, O Boticário, Companhia Paulista de Força e Luz (CPFL), Federação das Indústrias do Estado da Bahia (FIEB) e Natura. A construção da Metodologia Tear levou em consideração as lições aprendidas de cada uma dessas experiências, compilando o que deu certo em cada uma delas, para uma implementação efetiva do tema.

\footnotetext{
${ }^{12}$ A BSD Consulting - Business. Sustainability. Development - é uma empresa de consultoria de sustentabilidade global que oferece soluções pioneiras e personalizadas para a gestão de questões de sustentabilidade em empresas internacionais e organizações governamentais (BSD CONSULTING, 1998).
} 
Essa metodologia está dividida em quatro grandes fases, apresentadas na FIG.3.8, tendo como premissa o trabalho em rede e a incorporação na gestão da empresa dos mecanismos e produtos desenvolvidos (STOICOV e VÁRIOS COLABORADORES, 2007).

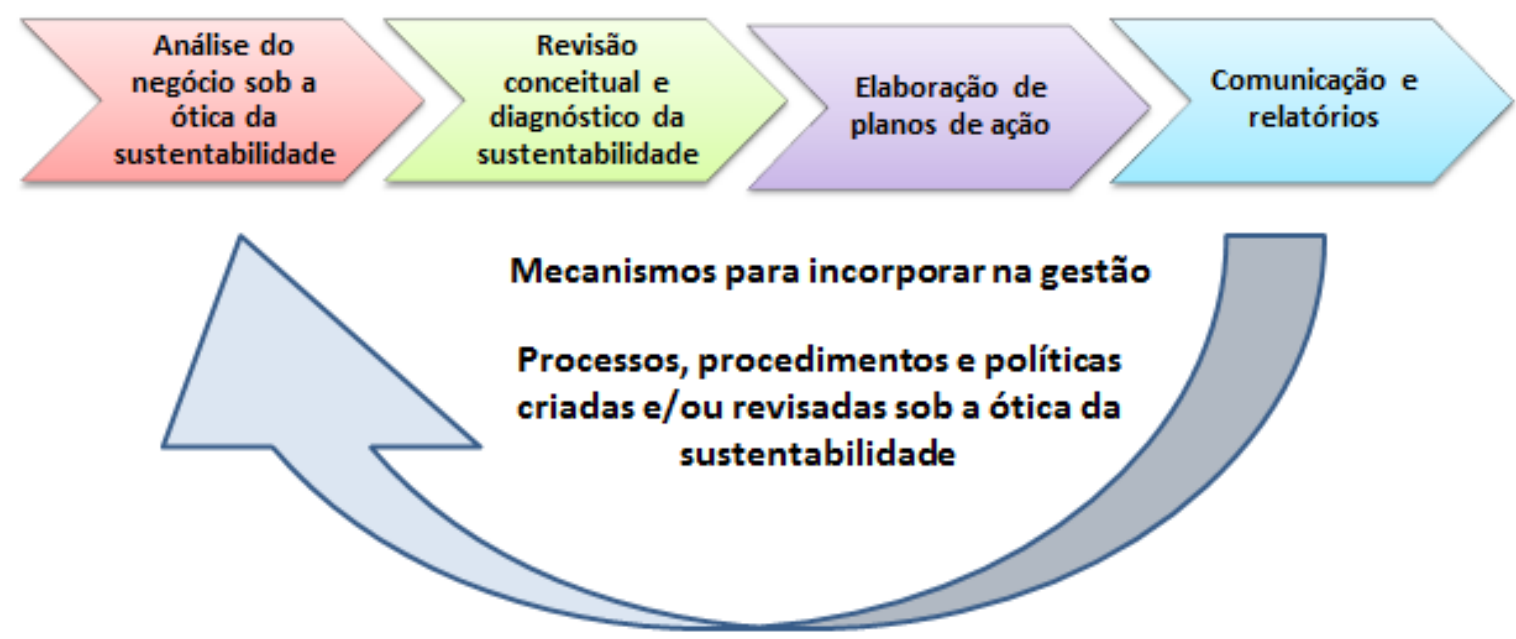

Fonte: (Programa Tear - Tecendo Redes Sustentáveis, 2007)

FIGURA 3.8 - Metodologia Tear - Tecendo Redes Sustentáveis

\subsubsection{Global Compact}

A Global Compact ou Pacto Global é uma comunidade empresarial internacional que atua na promoção de valores fundamentais nas áreas de direitos humanos, relações de trabalho e meio ambiente. Ela determina que as empresas devem contribuir para a criação de uma estrutura socioambiental consistente, em mercados livres e abertos, assegurando que todos desfrutem dos benefícios da nova economia global (UNITED NATIONS GLOBAL COMPACT, 2011).

O Pacto Global possui dez princípios que o fundamentam, sendo que nove foram estabelecidos na sua criação e um incluído posteriormente. Eles se derivaram de algumas declarações, são elas: Declaração Universal de Direitos Humanos, Declaração da Organização Internacional do Trabalho sobre Princípios e Direitos Fundamentais do Trabalho, Declaração do Rio sobre Meio Ambiente e 
Desenvolvimento e, também, Convenção das Nações Unidas contra a Corrupção (BHASIN, 2012).

O Pacto Global solicita às empresas para abraçar, apoiar e aprovar, na sua esfera de influência, um conjunto de valores fundamentais nas áreas de direitos humanos, normas de trabalho, meio ambiente e combate à corrupção. Estes valores podem ser definidos em dez princípios básicos (BHASIN, 2012):

\section{Direitos Humanos:}

Princípio 1: as empresas devem apoiar e respeitar a proteção dos direitos humanos reconhecidos internacionalmente;

* Princípio 2: certificar-se de que não são cúmplices de abusos dos direitos humanos.

Trabalho:

Princípio 3: as empresas devem apoiar a liberdade de associação e o reconhecimento efetivo do direito à negociação coletiva;

Princípio 4: a eliminação de todas as formas de trabalho forçado ou compulsório;

Princípio 5: a abolição efetiva do trabalho infantil;

Princípio 6: a eliminação da discriminação em matéria de emprego e ocupação.

Meio Ambiente:

Princípio 7: as empresas devem apoiar uma abordagem preventiva aos desafios ambientais;

Princípio 8: desenvolver iniciativas para promover maior responsabilidade ambiental;

Princípio 9: incentivar o desenvolvimento ea difusão de tecnologias ambientalmente amigáveis.

Anti-Corrupção:

Princípio 10: as empresas devem combater a corrupção em todas as suas formas, inclusive extorsão e propina. 


\subsubsection{Indicadores Ethos de Responsibilidade Social Empresarial}

Trata-se de um conjunto de indicadores lançado em 2002 pela organização não governamental Instituto Ethos para servir de ferramenta de auto avaliação do desempenho organizacional em relação às práticas de responsabilidade social. Enfoca aspectos sociais da sustentabilidade considerando a responsabilidade social empresarial como uma forma de gerenciar, buscando competitividade, sustentabilidade e atendendo às demandas da sociedade.

Os Indicadores Ethos foram desenvolvidos com o propósito de oferecer às empresas uma ferramenta de gestão para o diagnóstico e planejamento de suas práticas de responsabilidade social. Trata-se de uma ferramenta de uso essencialmente interno, que permite a auto avaliação da gestão, no que diz respeito à incorporação de práticas de responsabilidade social, além do planejamento de estratégias e do monitoramento do desempenho geral da empresa (INSTITUTO ETHOS, 2011).

No final de 2011, a BSD Consulting, juntamente com o Instituto Ethos, revisaram a terceira geração dos seus Indicadores de Corporate Social Responsibility (CSR), que são uma ferramenta: de autoavaliação, benchmarking ${ }^{13}$ e planejamento de gestão corporativa. Esses indicadores fornecem contribuições valiosas para empresas que queiram alinhar as suas práticas ou iniciar um processo de gestão de CSR (BSD CONSULTING, 2012).

A equipe da BSD criou o modelo de uma nova arquitetura para esses Indicadores que foi apresentado ao Conselho Técnico e validado em fevereiro de 2012 pelo Organismo de Orientação dos Indicadores, que é composto por vários representantes de stakeholders importantes. O trabalho apresentado pela BSD recebeu até o momento um feedback ${ }^{14}$ positivo dos membros do conselho, por ter criado indicadores que conseguem atuar em todas as áreas da responsabilidade social (BSD CONSULTING, 2012).

\footnotetext{
${ }^{13}$ Benchmarking é um processo contínuo de comparação dos produtos, serviços e práticas empresariais entre os mais fortes concorrentes ou empresas reconhecidas como líderes. É um processo de pesquisa que permite realizar comparações de processos e práticas "companhia-acompanhia" para identificar o melhor do melhor e alcançar um nível de superioridade ou vantagem competitiva (BSD CONSULTING, 2012).

14 Em administração, feedback (retorno de informação ou, simplesmente, retorno) é o procedimento que consiste no provimento de informação a uma pessoa sobre o desempenho, conduta ou ação executada por esta, objetivando reorientar ou estimular comportamentos futuros mais adequados (BSD CONSULTING, 2012).
} 
Os indicadores Ethos de Responsabilidade Social Empresarial são assim descritos (ETHOS, 2013):

Valores, Transparência e Governança:

compromissos éticos;

enraizamento da cultura organizacional;

governança corporativa;

relações com a concorrência;

diálogo e engajamento das partes interessadas;

balanço Social.

Público Interno:

relações com sindicatos;

gestão participativa;

compromisso com o futuro das crianças;

compromisso com o desenvolvimento infantil;

compromisso com a não discriminação;

compromisso com a equidade racial e de gênero;

relações com trabalhadores terceirizados;

politica de remuneração, benefícios e carreira;

cuidados com a saúde, segurança e condições de trabalho;

compromisso com o desenvolvimento profissional/empregabilidade;

comportamento nas demissões;

preparação para aposentadoria.

Meio Ambiente:

compromisso com a melhoria da qualidade ambiental;

educação e conscientização ambiental;

gerenciamento dos impactos sobre o meio ambiente;

sustentabilidade e economia florestal;

minimização de entradas e saídas de materiais

\section{Fornecedores:}

critérios de seleção e avaliação de fornecedores; 
trabalho infantil na cadeia produtiva;

trabalho forçado (ou escravo) na cadeia produtiva;

apoio ao desenvolvimento de fornecedores.

Consumidores e clientes:

política de comunicação comercial;

excelência no atendimento

conhecimento e gerenciamento dos danos potenciais de produtos e serviços.

Comunidade:

gerenciamento do impacto da empresa na comunidade de entorno;

relações com organizações locais;

financiamento de ação social;

envolvimento com a ação social.

Governo e sociedade:

contribuições para campanhas políticas;

construção da cidadania pelas empresas;

práticas anticorrupção e antipropina;

liderança e influência social;

participação em projetos sociais governamentais.

\subsection{Análise comparativa entre as metodologias e indicadores}

Após a apresentação sintética das dez iniciativas de mensuração da sustentabilidade e da responsabilidade social analisadas neste trabalho, segue abaixo um comparativo entre elas elaborado pela autora.

A primeira analise efetuada foi a analise de escopo, onde se procura definir quais são as dimensões que compõe cada uma das ferramentas que mensuram a sustentabilidade e a responsabilidade social. Para esta análise, elencaram-se as principais dimensões da responsabilidade social e atribuiu-se pesos (de zero a três) para cada uma delas, dependendo da ênfase dada por cada iniciativa, onde três indica que a dimensão é bastante significativa para a ferramenta e zero significa que a dimensão não é nada significativa para a ferramenta. A TAB. 3.1 representa esta análise. 
TABELA 3.1 - Análise do escopo das ferramentas de mensuração da Responsabilidade Social

\begin{tabular}{|c|c|c|c|c|}
\hline & Ambiental & Econômico & Social & Institucional \\
\hline $\begin{array}{l}\text { Indicadores de Desenvolvimento } \\
\text { Sustentável da Organização das Nações } \\
\text { Unidas (IDS) }\end{array}$ & 3 & 1 & 2 & 0 \\
\hline Dashboard de Sustentabilidade & 3 & 3 & 2 & 2 \\
\hline Barômetro de Sustentabilidade & 3 & 0 & 3 & 0 \\
\hline Global Reporting Initiative (GRI) & 3 & 3 & 3 & 1 \\
\hline Triple Bottom Line (TBL) & 3 & 3 & 3 & 0 \\
\hline $\begin{array}{l}\text { Métricas de Sustentabilidade da } \\
\text { Instituição dos Engenheiros Químicos } \\
\text { da Inglaterra (IChemE) }\end{array}$ & 2 & 3 & 2 & 1 \\
\hline Dow Jones Sustainability Index (DJSI) & 3 & 3 & 2 & 2 \\
\hline Metodologia Tear & 3 & 2 & 2 & 2 \\
\hline Global Compact & 3 & 2 & 3 & 0 \\
\hline $\begin{array}{l}\text { Indicadores Ethos de Responsabilidade } \\
\text { Social Empresarial }\end{array}$ & 3 & 3 & 3 & 3 \\
\hline
\end{tabular}

No que se refere à utilização de diferentes escopos pelos sistemas de indicadores, os indicadores Ethos são mais completos e abrangentes. Ele apresenta-se como a ferramenta que mais se destaca na dimensão institucional.

A segunda análise efetuada se refere a aplicabilidade dos indicadores de cada uma das ferramentas de mensuração da responsabilidade social à realidade das empresas e instituições. Para esta análise, elencaram-se três itens a serem avaliados: (quantidade de indicadores, facilidade do entendimento dos indicadores e adaptabilidade dos indicadores à realidade institucional). Atribuiu-se 
pesos (de zero a três) para cada um deles, dependendo dos indicadores de cada iniciativa, onde três indica que a iniciativa esta bastante adequada e zero significa que a iniciativa não é nada adequada. A TAB. 3.2 representa esta análise.

TABELA 3.2 - Análise da aplicabilidade das ferramentas de mensuração da Responsabilidade Social

\begin{tabular}{|c|c|c|c|}
\hline & $\begin{array}{l}\text { Quantidade } \\
\text { de } \\
\text { Indicadores }\end{array}$ & $\begin{array}{c}\text { Facilidade de } \\
\text { entendimento } \\
\text { dos } \\
\text { indicadores }\end{array}$ & $\begin{array}{c}\text { Adaptabilidade } \\
\text { dos } \\
\text { indicadores à } \\
\text { realidade } \\
\text { institucional }\end{array}$ \\
\hline $\begin{array}{l}\text { Indicadores de Desenvolvimento } \\
\text { Sustentável da Organização das } \\
\text { Nações Unidas (IDS) }\end{array}$ & 2 & 1 & 0 \\
\hline Dashboard de Sustentabilidade & 2 & 3 & 2 \\
\hline Barômetro de Sustentabilidade & 2 & 3 & 0 \\
\hline Global Reporting Initiative (GRI) & 2 & 2 & 1 \\
\hline Triple Bottom Line (TBL) & 2 & 3 & 0 \\
\hline $\begin{array}{l}\text { Métricas de Sustentabilidade da } \\
\text { Instituição dos Engenheiros Químicos } \\
\text { da Inglaterra (IChemE) }\end{array}$ & 2 & 1 & 1 \\
\hline Dow Jones Sustainability Index (DJSI) & 3 & 2 & 2 \\
\hline Metodologia Tear & 3 & 2 & 2 \\
\hline Global Compact & 2 & 2 & 0 \\
\hline $\begin{array}{l}\text { Indicadores Ethos de Responsabilidade } \\
\text { Social Empresarial }\end{array}$ & 3 & 3 & 3 \\
\hline
\end{tabular}


No que se refere à aplicabilidade dos indicadores das ferramentas de mensuração da responsabilidade social, os indicadores Ethos são mais aplicáveis. Ele possui uma quantidade adequada de indicadores, clareza no seu conteúdo e aparentemente é bastante adaptável ao contexto e realidades diferentes das empresas.

\subsection{Limitações das metodologias e indicadores}

Apesar destas iniciativas de mensuração, alguns fatores ainda limitam 0 uso desses indicadores tanto no nível público como no privado. A maior limitação é a falta de um conjunto de medidas-padrão de responsabilidade social amplamente aceitável (Sikdar, 2003; Searcy, Karapetrovic \& McCartney, 2005; Wang, 2005). Para Warhust (2002), a "proliferação de indicadores e metodologias leva a necessidade de definição de padrões metodológicos e conjuntos de indicadores comuns e de desenvolvimento de mecanismos apropriados para sua incorporação nos sistemas de mensuração.".

\subsection{Normas e certificações}

As normas e certificações existentes não se resumem apenas à padronização de procedimentos; elas concedem à empresa uma ampla reflexão a respeito das ferramentas de gestão a serem utilizadas para garantir 0 planejamento da evolução sustentável. Elas implicam na mobilização interna necessária para realizar um diagnóstico detalhado e no comprometimento da organização. Nesse sentido, as normas são também parte da estratégia das organizações (BARBIERI e CAJAZEIRA, 2009).

Para melhor compreensão dos conceitos de normas e certificações, a Embrapa (2001), demonstra que existe uma relação entre a "International Standardization Organization" (ISO), o Instituto Nacional de Metrologia, Qualidade e Tecnologia (INMETRO), o Comitê Brasileiro de Certificação (CBC) e a Associação Brasileira de Normas Técnicas (ABNT), conforme descrito abaixo:

a ISO é uma organização, sediada em Genebra na Suíça, reconhecida e aceita internacionalmente no estabelecimento de normas técnicas desenvolvidas e avaliadas no âmbito de competência de suas delegações nacionais; 
o INMETRO representa o CBC na ISO e possui, além das responsabilidades dadas aos seus membros, a atribuição de divulgar, avaliar e preservar a aceitação, o uso e integridade da marca ISO;

a ABNT é o organismo de certificação brasileiro, credenciado pelo INMETRO. Tem atuado na certificação de sistemas de garantia de qualidade no país.

Podem-se distinguir alguns tipos de normas de acordo com seus objetivos. São elas: a norma internacional ISO 9001, sobre o sistema de gestão da qualidade; a norma ISO 14001, sobre o sistema de gestão ambiental; a norma ISO 14063, sobre comunicação; a norma OHSAS 18001, sobre a gestão da saúde e da segurança do trabalho; a norma NBR 16001, sobre a gestão da responsabilidade; a norma AA 1000, sobre a relação da organização com as partes interessadas e a norma SA 8000 , sobre a gestão social da empresa e a relação com seu público interno (BARBIERI e CAJAZEIRA, 2012).

Apenas em dezembro de 2010 foi lançada a norma ISO 26000 que estabelece um padrão internacional de diretrizes de responsabilidade social. Ela não contém requisitos como nas normas ISO 9001 e ISO 14001, pois nestas normas de requisitos, a expressão usada é "deve" e a sua observância é obrigatória. Assim, não cabe à organização decidir se adota ou não o requisito. Caso não adote, a organização estará apresentando uma não conformidade. $\mathrm{Na}$ ISO 26000, a expressão é "convém que", mais adequada para fazer recomendações. As recomendações não são imperativas e não são necessariamente exigíveis (BARBIERI e CAJAZEIRA, 2012).

Houve muitas discussões sobre a natureza da não certificação da ISO 26000, e a decisão ainda hoje é contestada. Prevaleceu o argumento de que a abrangência da responsabilidade social é muito complexa e visa o desenvolvimento sustentável, assim, qualquer padrão para certificação seria insignificante e flexível (BARBIERI e CAJAZEIRA, 2012).

O processo de elaboração da ISO 26000 é inovador por ter como premissa a construção coletiva do conhecimento e a participação de vários stakeholders: consumidores, empresas, governos, organizações não governamentais, trabalhadores, além de organismos de normatização e entidades de pesquisa. Assim, um de seus destaques é a ampliação da participação de partes 
interessadas, em geral excluídas de processos dessa natureza (BARBIERI e CAJAZEIRA, 2012).

Internacionalmente, a ISO 14001, versão 1996, é o primeiro documento de caráter normativo a citar a necessidade de observar como a comunicação deve abordar os aspectos ambientais como forma de atender às partes interessadas. Essa norma apresenta os requisitos de um sistema de gestão ambiental para qualquer tipo de organização, e um dos instrumentos utilizados para cumprir essa norma é o Balanço Social (BARBIERI e CAJAZEIRA, 2009).

Uma significativa melhoria desse conceito foi desenvolvida ainda no âmbito da série14000 com a criação da norma ISO 14063 em 2006. Essa norma inseriu conceitos fundamentais à visão atual das comunicações institucionais. Fortemente inspirada no modelo de gestão da qualidade da ISO 9001 em que o processo é focado na satisfação dos clientes, a ISO 14063 introduz a ideia da comunicação como um processo focado nos stakeholders (BARBIERI e CAJAZEIRA, 2012).

As normas da série ISO 14000 não contemplam, por questões de escopo definido pelo TMB, os requisitos sociais demandados no modelo triple-bottom-line. Por isso novos modelos foram criados a partir de 2004 para as comunicações socioambientais, entre eles o mais popular e aceito internacionalmente é o modelo do Global Reporting Initiatives (GRI).

O modelo do GRI representa um avanço na evolução da comunicação com o acréscimo do atributo da responsabilidade social. Esse modelo busca conferir legitimidade à comunicação do desempenho das organizações nas três dimensões da sustentabilidade, ou seja, as dimensões econômica, social e ambiental (BARBIERI e CAJAZEIRA, 2009).

O padrão gerencial utilizado pelo GRI é um importante instrumento de relato da atuação das empresas para a sociedade e serve como ferramenta de melhoria do desempenho socioambiental. Entretanto esse padrão não indica caminhos e tampouco estabelece "como" fazer. Para isso, outro instrumento foi desenvolvido pela ISO, a norma ISO 26000, que fornece diretrizes para a responsabilidade social (BARBIERI e CAJAZEIRA, 2012). A FIG. 3.9 representa a evolução da comunicação nas normas internacionais de gestão. 


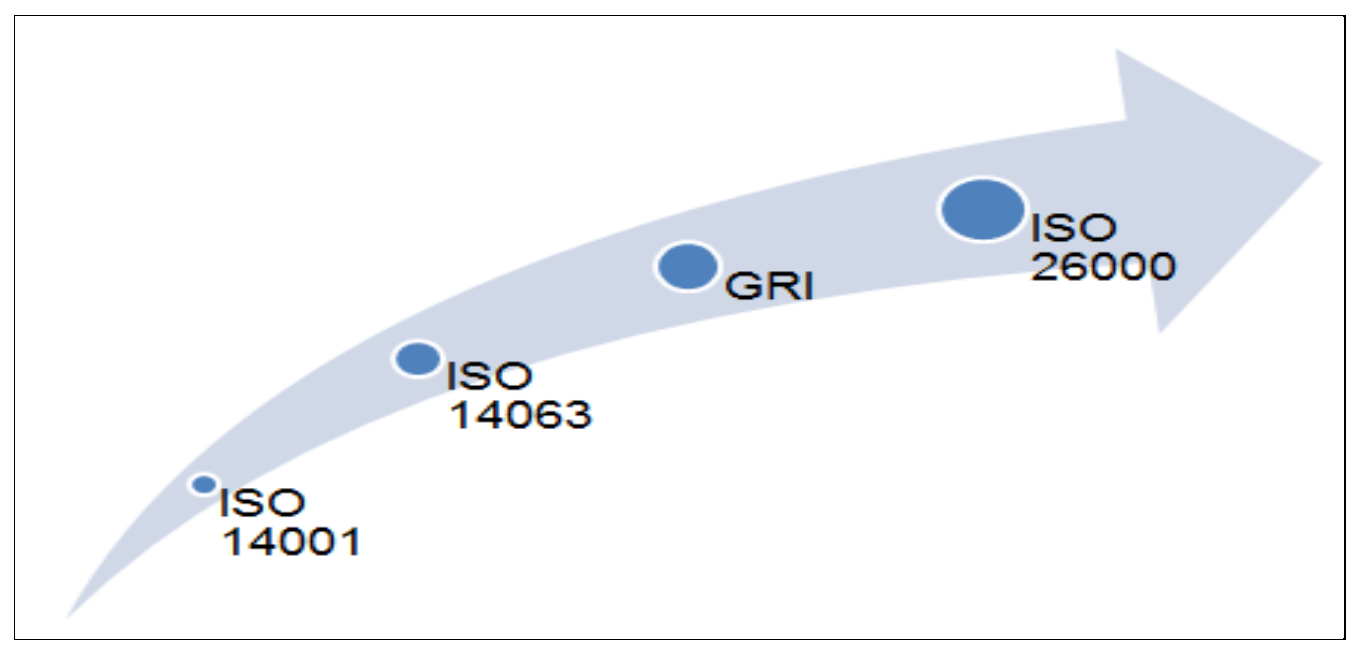

Fonte: (BARBIERI e CAJAZEIRA, 2009).

FIGURA 3.9 - A Evolução das comunicações nas normas internacionais de gestão

A TAB.3.3 apresenta um comparativo entre os princípios da comunicação entre as normas ISO 26000, GRI e ISO 14063.

TABELA 3.3 - Princípios das normas ISO 14063, GRI e ISO 26000

\begin{tabular}{lll}
\multicolumn{1}{c}{ ISO 14063 } & \multicolumn{1}{c}{ GRI } & \multicolumn{1}{c}{ ISO 26000 } \\
Transparência & Balanceamento & Balanceamento \\
\hline Relevância & Precisão & Precisão \\
\hline Responsividade & Comparabilidade & Disponibilidade \\
\hline Simplicidade & Simplicidade & Responsividade \\
\hline & Temporalidade & Simplicidade \\
\hline & & Temporalidade \\
\hline
\end{tabular}

Fonte: (BARBIERI e CAJAZEIRA, 2009)

Embora o IPEN utilize a ISO 9000 para garantir a qualidade de seus produtos e serviços para a comunidade em geral, essas normas não contemplam amplamente a questão da responsabilidade social. Por outro lado, há uma série de normas específicas da área nuclear adotas pela CNEN, com o objetivo de garantir a segurança da população. Essas normas serão descritas no item a seguir. 


\subsection{Normas da área nuclear}

O IPEN, principalmente por trabalhar com elementos que apresentam grande periculosidade a seus funcionários e a população como um todo é regido por uma série de normas que o auxiliam na execução de sua atividade fim com qualidade e segurança, contribuindo para que cada vez mais seus objetivos sejam cumpridos. Mais do que qualidade e segurança, trabalhar na área nuclear exige que todas as dimensões da responsabilidade social sejam adequadamente cumpridas, principamente no que tange a ética, meio ambiente, público interno e externo.

O Licenciamento de instalações nucleares e radiativas compreende um conjunto de atividades que visam garantir o cumprimento das normas regulatórias da CNEN e, portanto, garantir o uso seguro e pacífico da energia nuclear no país. Compreende basicamente as seguintes atividades (CNEN - LICENCIAMENTO, 2013):

concessão de atos, tais como: Licença para Construção, Autorização para Operação, Autorização para Modificação, Descomissionamento etc.;

avaliações de segurança por meio da realização de inspeções e auditorias in loco com a finalidade de verificar o cumprimento das normas regulatórias da CNEN;

controle da aquisição e movimentação (importação, exportação e transferência) de fontes e equipamentos geradores de radiação ionizante no âmbito de todo o território nacional;

certificação de profissionais para atuarem como supervisores de radioproteção ou operadores de reatores.

"As radiações contribuem com o bem-estar da sociedade em diversas áreas. Tão grande quanto os seus benefícios, porém, é a responsabilidade que o uso exige. A CNEN garante a segurança da população em geral, de quem lida diretamente ou se beneficia deste tipo de energia. Todas as instalações e trabalhadores que utilizam fontes radioativas obedecem as exigências de segurança estabelecidas pelas normas da CNEN." (CNEN - PROTEÇÃO RADIOLÓGICA, 2012). 
Na TAB.3.4 é apresentada a relação dos grupos de normas vigentes na CNEN.

TABELA 3.4 - Grupos de normas da CNEN

\begin{tabular}{cl} 
Grupo & \multicolumn{1}{c}{ Descrição } \\
\hline 1 & Instalações Nucleares \\
\hline 2 & Controle de Materiais Nucleares, Proteção Física e Proteção contra Incêndio \\
\hline 3 & Proteção Radiológica \\
\hline 4 & Materiais, Minérios e Minerais Nucleares. \\
\hline 5 & Transporte de Materiais Radioativos \\
\hline 6 & Instalações Radiativas \\
\hline 8 & Certificação e Registro de Pessoas \\
\hline Fonte: (CNEN - NORMAS, 2012)
\end{tabular}

Para executar suas atividades, a CNEN possui 14 unidades localizadas em nove estados brasileiros, conforme TAB. 3.5.

TABELA 3.5 - Unidades da CNEN

\begin{tabular}{|c|c|c|}
\hline Unidades da CNEN & Cidade & Estado \\
\hline Unidade Central - Sede & Rio de Janeiro & RJ \\
\hline Centro de Desenvolvimento da Tecnologia Nuclear - CDTN & Belo Horizonte & MG \\
\hline Centro Regional de Ciências Nucleares do Centro-Oeste - CRCN-CO & Goiânia & GO \\
\hline Centro Regional de Ciências Nucleares do Nordeste - CRCN-NE & Recife & PE \\
\hline Distrito de Angra dos Reis - DIANG & Angra dos Reis & RJ \\
\hline Distrito de Caetité - DICAE & Caetité & $\mathrm{BA}$ \\
\hline Distrito de Fortaleza - DIFOR & Fortaleza & CE \\
\hline Distrito de Porto Alegre - DIPOA & Porto Alegre & $\mathrm{RS}$ \\
\hline Distrito de Resende - DIRES & Resende & RJ \\
\hline Escritório de Brasília - ESBRA & Brasília & DF \\
\hline Instituto de Engenharia Nuclear - IEN & Rio de Janeiro & RJ \\
\hline Instituto de Pesquisas Energéticas e Nucleares - IPEN & São Paulo & SP \\
\hline Instituto de Radioproteção e Dosimetria - IRD & Rio de Janeiro & RJ \\
\hline Laboratório de Poços de Caldas - LAPOC & Poços de Caldas & MG \\
\hline
\end{tabular}

No ANEXO A, estão especificadas as normas para cada um dos grupos descritos anteriormente. Essas normas se aplicam a todas as instalações nucleares e radioativas da CNEN. Os requisitos de segurança e radioproteção são os mesmos exigidos às demais instalações nucleares e radiativas do país. $O$ 
processo de certificação permite assegurar que essas instalações atendam aos requisitos de segurança e radioproteção, não acarretando risco aos operadores, ao meio ambiente e aos indivíduos do público.

$\mathrm{Na}$ ausência de normatização brasileira adequada, as normas da Agência Internacional de Energia Atômica (AIEA) ou normas internacionais ou de países tecnicamente desenvolvidos devem ser usadas, desde que as mesmas sejam aceitais pela CNEN (PORTARIA CNEN/IPEN N.96, 2012).

Conforme portaria CNEN/IPEN N.96, de 26 de abril de 2012, 0 Superintendente do IPEN, no uso das atribuições e competências que the são conferidas, resolveu constituir grupos de trabalho para a elaboração e redação dos documentos relativos ao processo de licenciamento das instalações nucleares e radiativas do IPEN. Foram constituídos 23 grupos de trabalho que identificaram as necessidades de adequação da infraestrutura das respectivas instalações para atender a todos os requisitos normativos pertinentes ao processo geral de licenciamento das instalações nucleares e radiativas do IPEN (PORTARIA CNEN/IPEN N.96, 2012). A relação dos grupos de trabalho pode ser vista no ANEXO B.

É de competência do representante do Comitê de Avaliação de Segurança do IPEN (CASI) ou seu suplente, a verificação do atendimento dos requisitos normativos, em toda a documentação elaborada pelos grupos de trabalho. A Diretoria de Segurança é responsável pela gestão do processo geral de licenciamento das instalações nucleares e radiativas do IPEN. Cabe ao Centro de Engenharia Nuclear (CEN) a criação do link Licenciamento das Instalações Nucleares e Radiativas, na intranet do IPEN. Isso colaborará com a responsabilidade social dessa instituição.

Após a revisão da literatura e a fundamentação teórica sobre o tema, foi elaborado o desenvolvimento teórico do trabalho, apresentado no próximo capítulo. 


\section{DESENVOLVIMENTO DO TRABALHO}

Neste capítulo são apresentadas as etapas efetuadas para o desenvolvimento do trabalho, que foram divididas da seguinte forma: (1) proposição do modelo teórico, definindo as suas dimensões, escalas de medida e definições de hipótese e (2) os procedimentos metodológicos utilizados para atingir o principal objetivo desse trabalho, que é descrever e analisar a responsabilidade Social do IPEN com base no modelo teórico proposto.

Na FIG.4.1 são apresentadas esquematicamente as etapas realizadas para a obtenção do modelo teórico proposto. Na FIG.4.2 estão descritos os procedimentos metodológicos utilizados para atingir o objetivo do trabalho. Em seguida, cada etapa será detalhadamente descrita.

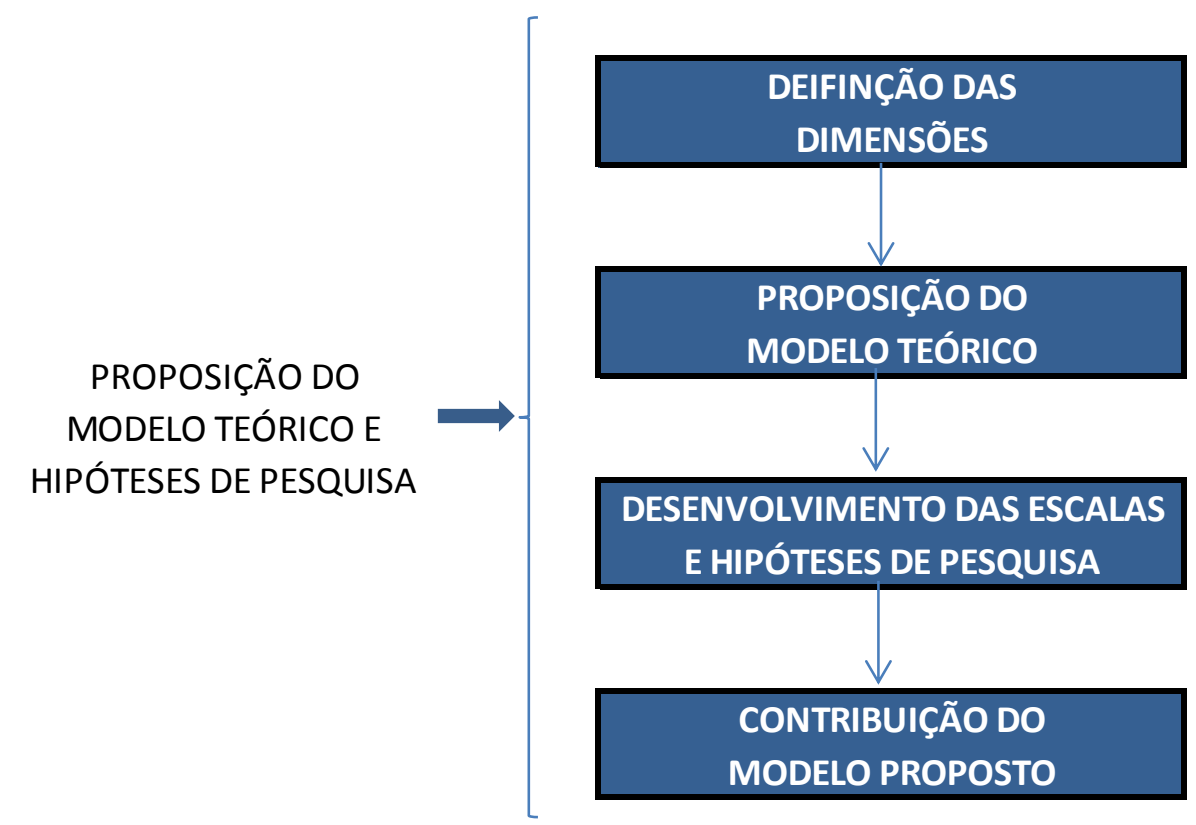

FIGURA 4.1 - Etapas do desenvolvimento do modelo teórico proposto 


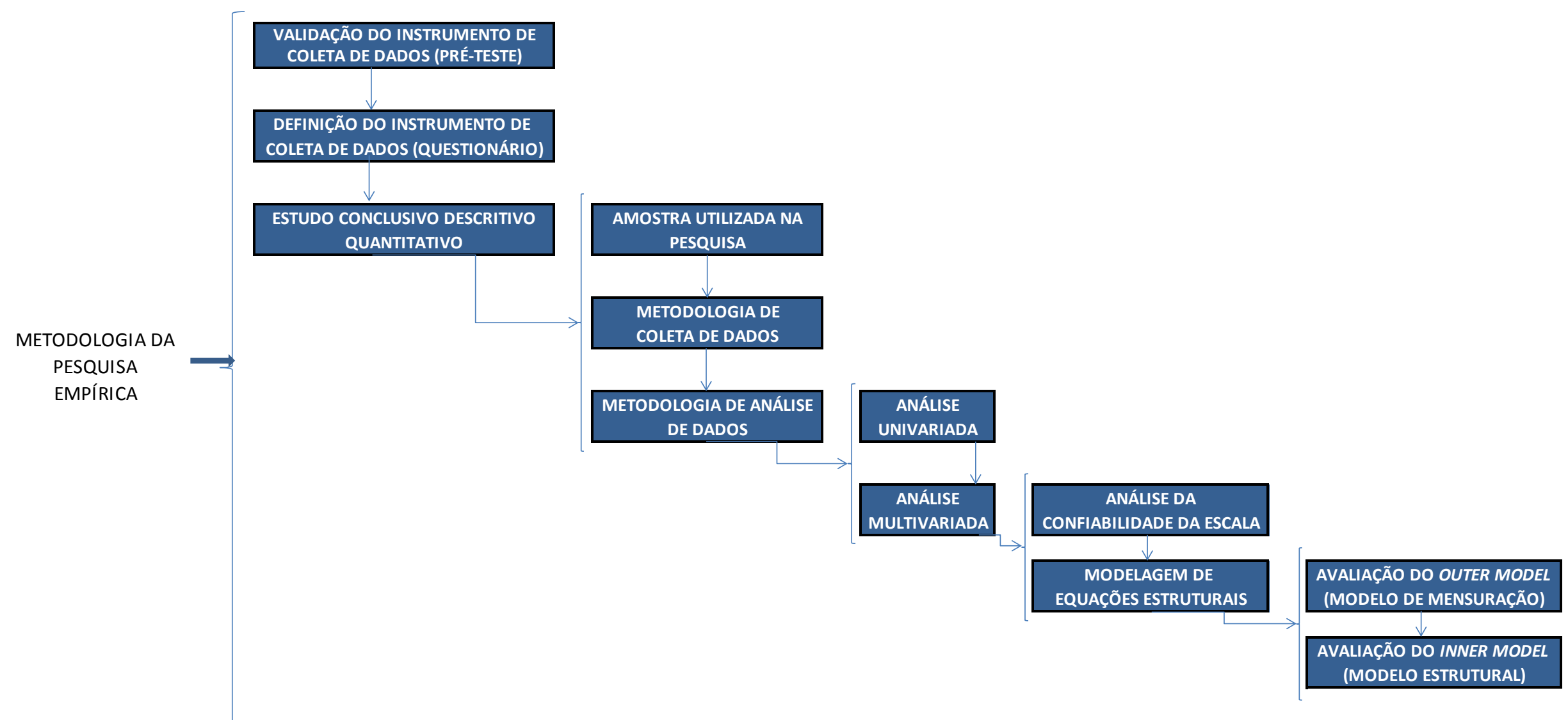

FIGURA 4.2 - Etapas dos procedimentos metodológicos 
Como o IPEN será utilizado para a avaliação da responsabilidade social, é importante descrever resumidamente as suas atividades desenvolvidas e o que existe com relação à responsabilidade social da instituição com a população em geral.

O IPEN foi fundado em 1956 por meio de um convênio entre o Conselho Nacional de Pesquisa (CNPq) e a Universidade de São Paulo (USP). Em 1957, o primeiro reator de pesquisa IEA-R1 iniciou sua operação. O IPEN deu início à produção de radiofármacos no Brasil em 1959 e inaugurou as instalações do Centro de Radiofarmácia em 1976. Desde então, o IPEN tem desenvolvido atividades na área de pesquisa e desenvolvimento nuclear no país. Como já mencionado, o IPEN é uma autarquia estadual vinculada à Secretaria de Ciência e Tecnologia associada à Universidade de São Paulo para fins de ensino, gerido técnica e administrativamente pela Comissão Nacional de Energia Nuclear (CNEN) (IPEN - QUEM SOMOS, 2011).

O IPEN tem hoje uma destacada atuação em vários setores da atividade nuclear. São eles:

\section{Aplicações de técnicas nucleares:}

- física nuclear e radioquímica;

- aplicação na engenharia e na indústria.

\section{Ensino e informação científica}

- treinamento e aperfeiçoamento;

- informação científica;

- pós-graduação;

- graduação.

\section{Materiais}

- síntese e processamento de materiais;

- caracterização de materiais;

- laser e aplicações;

- processos químicos;

- tecnologia do combustível nuclear. 


\section{Meio ambiente}

- diagnóstico e monitoração ambiental;

- tratamento de resíduos.

\section{Reatores nucleares}

- operação e utilização de reatores de pesquisa;

- engenharia de reatores nucleares.

\section{Saúde}

- biotecnologia;

- radiofarmácia.

\section{Segurança radiológica}

- radioproteção ocupacional e ambiental;

- gestão de rejeitos radioativos;

- metrologia das radiações.

\section{Segundo o site do IPEN:}

“(..) resultados destas atividades vêm proporcionando avanços significativos no domínio de tecnologias, na produção de materiais e na prestação de serviços de valor econômico e estratégico para o país, possibilitando estender os benefícios da energia nuclear a segmentos maiores de nossa população." (IPEN - QUEM SOMOS, 2011).

Uma das exigências legais a ser cumprida pelo IPEN é realizar um rigoroso programa de controle radiológico e de segurança nuclear. Esse programa atinge todas as instalações nucleares e radioativas do IPEN. Ele é responsável por monitorações radiológicas, pessoal e ambiental, atendimento a emergências radiológicas, análises radiotoxicológicas, avaliações radiosanitárias, calibração de monitores de radiação, tratamento e acondicionamento de rejeitos nucleares de baixa atividade (IPEN - QUEM SOMOS, 2011). 
Essas atividades realizadas pelo IPEN/CNEN ganharam maior atenção e preocupação por parte da sociedade brasileira após o acidente radioativo de Goiânia ${ }^{15}$.

O IPEN, ao longo de sua história, vem adotando ações de controle e monitoração ambiental. No entanto, com o passar dos anos, todas as medidas de proteção radiológicas têm sido integradas e consolidadas em relatórios mensais e anuais. Alguns desses documentos são avaliados e aprovados pelo Conselho Técnico Administrativo do IPEN (IPEN - MEIO AMBIENTE, 2009).

Muitas são as ações de cidadania executadas pelo IPEN. Algumas delas estão descritas a seguir (IPEN - AÇÕES DE CIDADANIA, 2011):

apresentações culturais;

atividades lúdicas;

programa de saúde bucal;

campanhas de doação;

investimentos em equipamentos modernos;

investimentos continuados nos funcionários;

treinamento técnico especializado;

acesso a cursos de pós-graduação;

oferta de cursos de alfabetização, ensino fundamental e médio para funcionários, parentes de funcionários e empresas terceirizadas;

acesso a cursos de nível superior a distância;

recursos financeiros disponibilizados para desenvolvimento de pesquisas em cada um dos seus centros;

eventos para reforçar o vínculo empresa-família:

- portas abertas;

- festa junina;

- dia das crianças;

- dia das mães;

- famílias têm livre acesso a parte do instituto reservado a recreação e práticas esportivas;

\footnotetext{
${ }^{15}$ Em setembro de 1987 aconteceu o acidente com Césio-137 em Goiânia, capital do Estado de Goiás, Brasil. O manuseio indevido de um aparelho de radioterapia abandonado onde funcionava o Instituto Goiano de Radioterapia, gerou um acidente que envolveu direta e/ou indiretamente centenas de pessoas (WASCHECK, 2007).
} 
criação, em 2001, do Grupo de Ações para a Cidadania por servidores voluntários. O grupo organiza campanhas de doação e atividades em entidades assistenciais para crianças carentes;

oferta de vagas para a incubação de empresa no CIETEC (Centro Incubador de Empresas Tecnológicas);

plano médico autogerido;

exames periódicos realizados em todos os seus funcionários pelo menos uma vez ao ano;

pesquisa realizada periodicamente de clima organizacional. Os resultados são divulgados juntamente com as sugestões de melhorias;

homepage e intranet, onde é possível ter acesso às informações da Instituição;

jornal bimestral "Órbita IPEN", que descreve as principais atividades e prêmios recebidos devido às pesquisas realizadas na Instituição. Possui tiragem de três mil exemplares, distribuído dentro e fora da Instituição;

\section{Retorno social de sua atividade}

Muitos são os retornos sociais de sua atividade fim onde podemos destacar os itens abaixo descritos (IPEN - AÇÕES DE CIDADANIA, 2011):

\# produção anual de dois milhões de doses de radioisótopos, fundamentais para o tratamento de graves doenças;

transferência de tecnologia da irradiação para o prolongamento da vida útil de alimentos, possibilitando que cheguem em qualquer ponto do país e até em outros continentes com qualidade requerida para o consumo humano.

A FIG. 4.3 apresenta uma foto panorâmica do IPEN, obtida de seu site onde estampa a importância dada à melhoria da qualidade de vida da população (IPEN - QUEM SOMOS, 2011). 


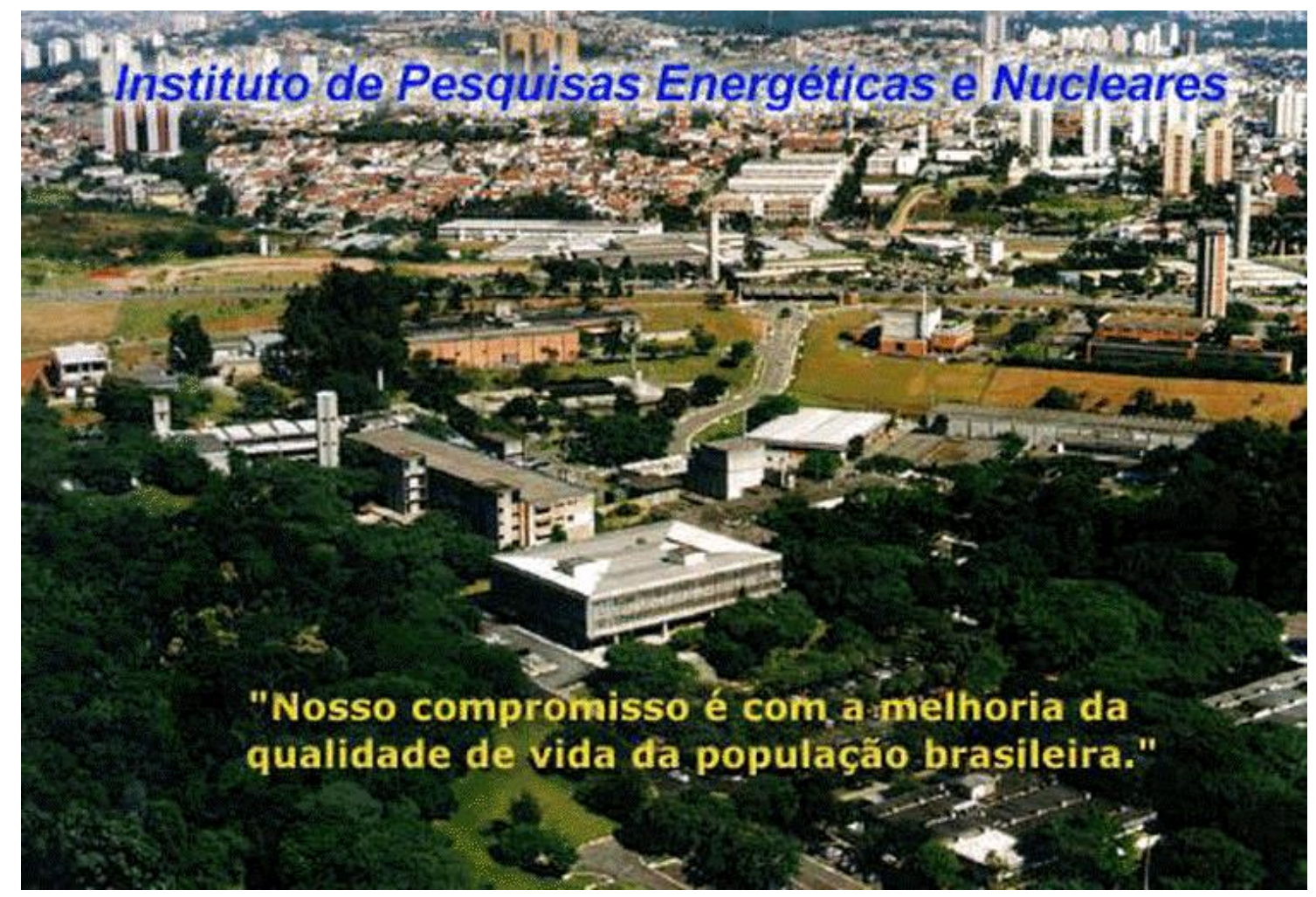

FIGURA 4.3 - Foto panorâmica do IPEN

A fim de verificar se os conceitos de responsabilidade social estão sendo aplicados, percebidos e compreendidos pelos colaboradores do IPEN, a seguir será fornecido o modelo teórico para o desenvolvimento deste trabalho.

\subsection{Proposição do modelo teórico e hipóteses de pesquisa}

Qualquer que seja a teoria que oriente as práticas de responsabilidade social, sempre haverá dificuldades para implementá-las, por diversas razões. Uma das razões envolve uma diversidade de questões que se traduzem em direitos, obrigações e expectativas de diferentes públicos, sendo eles internos e externos à organização. Os diferentes entendimentos a respeito das organizações e de suas relações com a sociedade e com o meio ambiente são mais uma fonte de complexidade. Tudo isso é feito concomitantemente às atividades e operações das organizações em busca de resultados favoráveis. Um modo tradicionalmente bem-sucedido de lidar com essa situação complexa é por meio da análise de cada razão separadamente. Esse é o esquema usado por Carroll, um dos 
principais expoentes do movimento da responsabilidade social empresarial, cuja obra tem sido uma inesgotável fonte de inspiração (BARBIERI e CAJAZEIRA, 2012).

Com base na pesquisa bibliográfica, associada a algumas reflexões próprias, mas com forte embasamento no trabalho efetuado pelo Instituto Ethos de Responsabilidade Social ${ }^{16}$ e pela United Nations Departament of Economic and Social Affairs $^{17}$, este trabalho foi desenvolvido. Cumpre esclarecer que foi selecionado um elenco de dimensões que fossem passíveis de mensuração, que são as seguintes: ética, público interno, meio ambiente, fornecedor, cliente, comunidade, governo e sociedade.

\subsubsection{Definição das dimensões}

A dimensão referente à ética, que está fortemente ligada à estratégia e à transparência, procura demonstrar até que ponto o IPEN evidencia e dissemina, por meio de suas linhas estratégicas globais, a prática de uma gestão socialmente responsável. Essa dimensão verifica se há abertura para discussão de questões estratégicas dentro da Instituição e procura avaliar se ela efetivamente pratica uma gestão de transparência com base nos diálogos estruturados com as partes interessadas. Também verifica se a Instituição compartilha informações com outras organizações e se divulga os resultados obtidos mediante publicação de Balanços Sociais/Relatórios de Gestão.

A dimensão referente ao público interno evidencia esforços e atitudes comprometidas com o bem-estar dos seus trabalhadores em todos os sentidos, reconhecendo o seu valor, combatendo discriminações, mantendo e ampliando os atuais níveis de empregabilidade, promovendo programas de capacitação e políticas de benefícios para seus funcionários/dependentes.

A dimensão referente ao meio ambiente investiga os possíveis impactos ambientais causados pelas atividades do Instituto, bem como se há conhecimento

\footnotetext{
${ }^{16}$ O Instituto Ethos de Empresas e Responsabilidade Social é uma Organização da Sociedade Civil de Interesse Público (OSCIP), cuja missão é mobilizar, sensibilizar e ajudar as empresas a gerir seus negócios de forma socialmente responsável, tornando-as parceiras na construção de uma sociedade justa e sustentável (INSTITUTO ETHOS, 2013).

${ }^{17}$ Departamento das Nações Unidas de Assuntos Econômicos e Sociais (DESA) trabalha em estreita colaboração com os governos e as partes interessadas para ajudar os países ao redor do mundo a atingir suas metas econômicas, sociais e ambientais (UNITED NATIONS DEPARTMENT OF ECONOMIC AND SOCIAL AFFAIRS, 2001).
} 
desses impactos. Também foca nas ações preventivas, nos processos que oferecem danos potenciais à saúde, segurança de seus trabalhadores e população em torno. Essa dimensão verifica se o Instituto estabelece e desenvolve programas de educação ambiental, destinados à comunidade na qual ele está inserido. Verifica, também, se o Instituto realiza análises de impacto de todos os seus processos, independentemente do cumprimento das ações legais, e se utiliza de forma coerente e racional os recursos naturais e materiais envolvidos na execução de suas atividades.

As dimensões referentes aos fornecedores e clientes procura valorizar a relação da Instituição com essas entidades. Verifica se oferece aos seus clientes a mesma gama de benefícios obtidos quando da negociação com seus fornecedores. Avalia se existe parceria entre a Instituição e os fornecedores, se ela busca, além de um preço justo, o quanto o fornecedor é também socialmente responsável. Mede o relacionamento entre a Instituição e seus clientes, checando se existe uma linha aberta de comunicação, além do apoio necessário no contexto geral desta relação.

Comunidade é a dimensão que aponta para um relacionamento eficaz e socialmente responsável para com a comunidade na qual o Instituto está inserido. É comum afirmar que sob o "pano de fundo" de uma atuação realmente comprometida com os interesses, anseios e necessidades comunitárias, muitas organizações se utilizam do artifício da filantropia para minorar ou atenuar os impactos de sua atuação nas comunidades. Embora a filantropia seja considerada uma parte importante das ações que promovem a justiça social, deve-se notar que ela é apenas uma parte do todo e, como não atua nas causas fundamentais dos desequilíbrios sociais, tem seu poder limitado, pois somente ameniza os sintomas dos desequilíbrios. Assim, a responsabilidade social é mais abrangente do que a filantropia.

Segundo Mendonça (2003), antes da adoção de qualquer ação, até mesmo a filantrópica, a responsabilidade social obrigatoriamente tem que:

identificar, reconhecer e caracterizar os aspectos sociais do Instituto, bem como a sua conduta com relação aos meios de vida e organização social da comunidade na qual está inserido;

avaliar e determinar o tipo e o grau de mudança causada por tais aspectos na qualidade de vida das pessoas da comunidade; 
estabelecer e gerenciar os planos de ação que promovam a melhoria nos padrões de desempenho social do Instituto.

A dimensão governo e sociedade avalia o comportamento do Instituto com base nos seus relacionamentos e ações direcionadas aos aspectos governamentais e sociais. Ela mensura a sua participação em associações, fóruns empresariais, ações que contribuem para a elaboração de programas, processos e propostas concretas de interesse público e de caráter social reconhecidamente comprovado.

Segundo a United Nations Departament of Economic and Social Affairs (2001), a conquista do desenvolvimento sustentável é uma aspiração de abrangência universal, e a escolha de indicadores reflete as situações e especificidades de cada país. Eles servem para indicar variações, comportamentos, processos e tendências, além de estabelecer comparações entre países, regiões e empresas. Indicam também as necessidades e prioridades para formulação, monitoramento e avaliação de políticas públicas.

Como já indicado na introdução do trabalho, o objetivo geral desse estudo é propor um modelo teórico multidimensional para descrever e analisar a responsabilidade socioambiental do IPEN. Esses objetivos norteiam 0 desenvolvimento do modelo teórico apresentado a seguir, o qual tem como base o levantamento bibliográfico e definição das dimensões acima descritas.

\subsubsection{Proposição do modelo teórico}

O ponto de partida para a elaboração do modelo teórico foi a definição do conceito de responsabilidade social que, conforme demonstrado na revisão da literatura, não representa uma unanimidade entre os estudiosos. Em vista disto, para esse estudo, é proposta uma definição própria, apoiada nos elementos conceituais com maior nível de consenso, acrescida de alguns elementos que, na visão da autora deste trabalho, poderiam contribuir para uma definição mais abrangente do constructo. Assim, no início da investigação empírica, o conceito de responsabilidade social utilizado como fundamento da modelagem multidimensional abrangia os seguintes elementos: ética, público interno, meio ambiente, cliente, fornecedor, comunidade e governo/sociedade. 
O modelo teórico proposto para a investigação empírica é do tipo reflexivo-formativo ${ }^{18}$, no qual o constructo responsabilidade social é considerado uma abstração ou variável latente de segunda ordem, cujos componentes formativos de primeira ordem ou variáveis latentes são: ética, público interno, meio ambiente, cliente, fornecedor, comunidade e governo/sociedade. Esses componentes são manifestados por múltiplos indicadores reflexivos, que são as variáveis observadas por meio do levantamento empírico (JARVIS et al. 2003; DIAMANTOPOULOS e SIGUAW, 2006; WHITTAKER et al., 2007).

As dimensões que não são medidas diretamente são chamadas de constructos ou variáveis latentes. Cada constructo pode ser medido de maneira aproximada por meio de indicadores. Esses indicadores que servem para medir um constructo também são chamados de variáveis observadas (HAIR et al. 2011).

Com base nos conceitos levantados na revisão da literatura e em discussões realizadas com especialistas no assunto, foi elaborado um modelo conceitual e suas respectivas hipóteses (FIG. 4.4).

\footnotetext{
${ }^{18}$ Indicadores Formativos formam o constructo, ou seja, eles são utilizados para definir o constructo. Indicadores Reflexivos são considerados "efeitos" dos constructos, em outras palavras, os constructos causam esses indicadores (CHIN, 1998).
} 


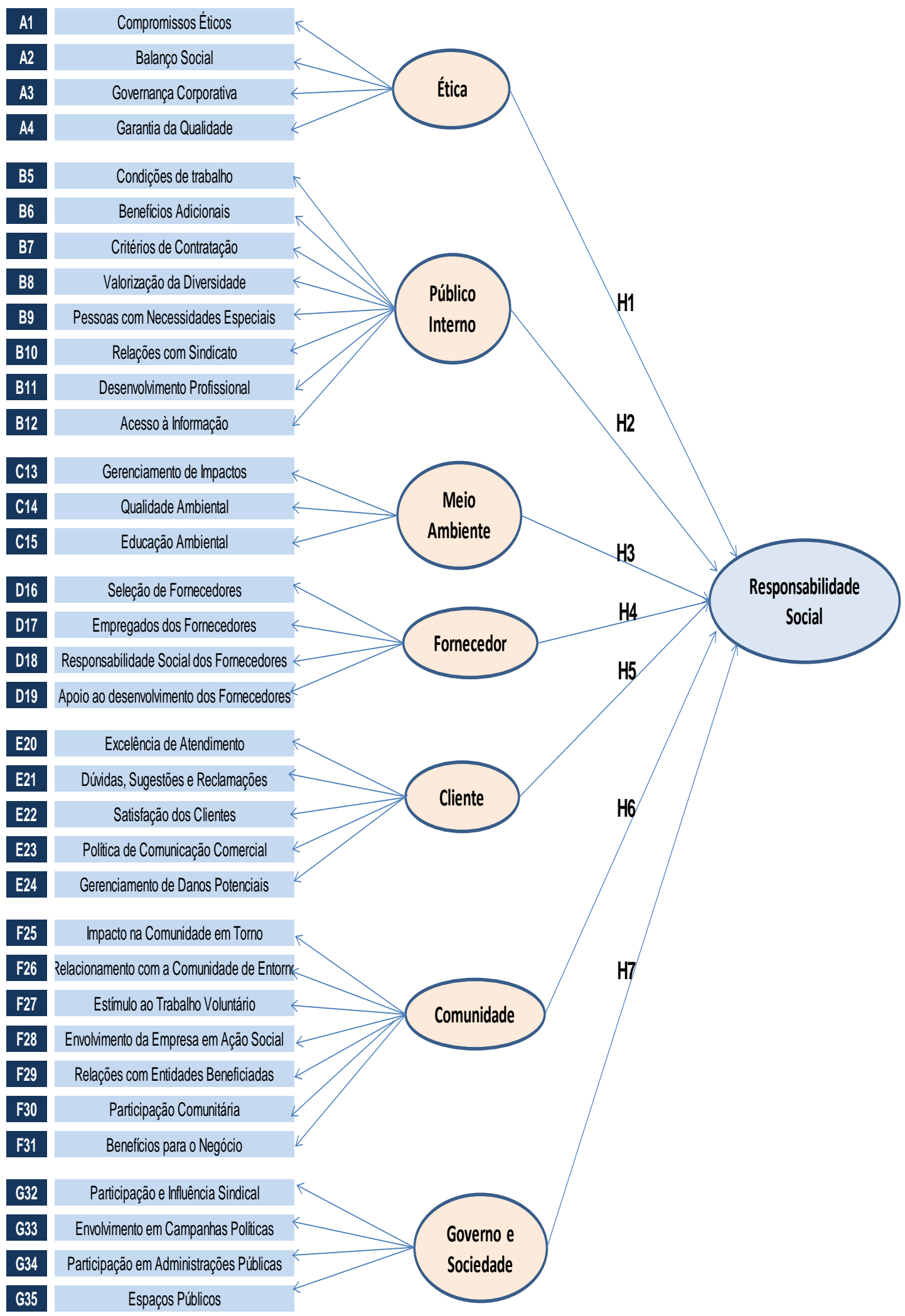

FIGURA 4.4 - Modelo teórico proposto 
Onde os seguintes indicadores reflexivos mensuram os constructos:
$A_{n}(n=1$ a 4): Ética;
$B_{n}(n=5$ a 12): Público Interno;
$C_{n}(n=13$ a 15$)$ : Meio Ambiente;
$D_{n}(n=16$ a 19): Fornecedor;
$E_{n}(n=20$ a 24): Cliente;
$F_{n}(n=25$ a 31$):$ Comunidade;
$G_{n}(n=32$ a 35): Governo e Sociedade.

$\mathrm{Na}$ FIG. 4.4, $\mathrm{H}_{\mathrm{n}}$ ( $\mathrm{n}=1$ a 7 ) são apresentadas as hipóteses assumidas nesse trabalho, as quais serão descritas a seguir.

\subsubsection{Desenvolvimento das escalas e hipóteses de pesquisa}

Os constructos que compõem o modelo teórico serão classificados de forma a embasar as hipóteses formuladas. Juntamente com a explicação sobre o papel de cada constructo, serão detalhadas as escalas utilizadas para medir cada um deles.

Segundo Miller (1991), as escalas empregadas em um questionário exercem um papel significativo na coleta de dados empíricos, pois fornecem medidas quantitativas que possibilitam obter maior precisão, além de permitir manipulações estatísticas e interpretações explicitas. Os itens destinados a mensurar o constructo e seu respectivo domínio devem ser cuidadosamente definidos e especificados a partir da teoria disponível, tendo como base a literatura e o entendimento do próprio pesquisador a fim de serem avaliados com a ajuda de técnicas matemáticas (CHURCHILL, 1979).

Portanto, as escalas já existentes na literatura acadêmica foram pesquisadas para a elaboração do questionário. Uma vez que o modelo proposto para este estudo é bastante extenso e destinado, particularmente, à responsabilidade social, existem poucas escalas específicas para os objetivos propostos. Algumas escalas já existentes serviram de base e foram reescritas ou adaptadas para medir os constructos do modelo proposto.

As sete dimensões utilizadas no modelo conceitual proposto nesse trabalho são detalhadas a seguir.

\subsubsection{1 Ética}

Os princípios que evidenciam a cultura de uma empresa devem permear todas as suas ações, desde a tomada de decisões estratégicas e cotidianas até o 
relacionamento com seu público. Empresas preocupadas em estabelecer compromissos éticos são orientadas por valores que são disseminados, cumpridos e adaptados aos novos tempos. Tão importante quanto informar os valores para o público externo é garantir que sejam compartilhados e assimilados pelos colaboradores. As pesquisas de clima organizacional são importantes medidores do conhecimento da cultura e balizadores de ações futuras das empresas (WEINGRILL, 2003).

Com relação à ética, a seguinte hipótese é proposta:

H1: Há uma relação positiva entre a dimensão ética e a responsabilidade social.

Para essa dimensão os itens da escala elaborados pela autora desse trabalho tiveram como referência os trabalhos do Instituto Ethos de Responsabilidade Social e os conceitos teóricos de ética empresarial (CUSTODIO e MOYA, 2007; ASHLEY, 2005). Na TAB.4.1 são apresentados os indicadores referentes à dimensão ética.

TABELA 4.1 - Indicadores da dimensão ética

\begin{tabular}{cll}
\hline CóDIGO & & INDICADORES \\
A1 & Compromissos Éticos & \\
A2 & Balanço Social \\
A3 & Governança Corporativa & \\
A4 & Garantia da Qualidade & \\
\hline
\end{tabular}

O indicador compromissos éticos avalia se os valores e princípios do IPEN existem em um documento formal, que conta com um processo de difusão sistemático com foco no público interno e se está sob a responsabilidade de uma pessoa ou área responsável.

$O$ indicador balanço social verifica se o Instituto elabora anualmente um balanço social, descrevendo suas ações sociais e ambientais, quantificando esses aspectos.

$O$ indicador governança corporativa avalia se 0 conselho de administração, conselho consultivo ou estrutura similar tem compromissos, 
políticas explícitas e mecanismos que garantam a integridade dos relatórios financeiros, priorizando a transparência na prestação de contas e outras informações. Avalia, também, se o Instituto possui separação clara entre a prestação de serviços, comercialização de seus produtos e a pesquisa acadêmica.

O indicador garantia da qualidade identifica se o Instituto possui um programa de acompanhamento sistemático e avaliação dos diferentes aspectos de um projeto ou serviço e avalia se existe algum mecanismo para garantir que os padrões de qualidade estão sendo cumpridos.

\subsubsection{Público Interno}

Segundo Weingrill (2003), a capacidade de dialogar com o público interno inclui práticas especificas para diferentes esferas. Em relação aos sindicatos, é fundamental a criação de canais efetivos de comunicação, com a transmissão de informações sobre as condições de trabalho, dados financeiros e objetivos estratégicos que atinjam diretamente os trabalhadores.

Ações pelas quais as organizações podem atuar junto a seu público interno são apresentadas nesse item do trabalho. São elas: gestão participativa, investimento na educação de seus colaboradores, programas que demonstrem o compromisso da empresa com o futuro dos filhos adolescentes e jovens dos funcionários e da comunidade em torno, práticas que valorizem a diversidade e promovam a equidade funcional e investimento na saúde e bem- estar do funcionário (WEINGRILL, 2003; REIS, 2007; BARBIERI e CAJAZEIRA, 2012).

Com base nos itens acima, a seguinte hipótese foi formulada:

H2: Há uma relação positiva entre a dimensão público interno e a responsabilidade social.

Para essa dimensão, os itens da escala elaborados nesta dissertação tiveram como referência os trabalhos do Instituto Ethos de Responsabilidade Social (CUSTODIO e MOYA, 2007). Na TAB.4.2 são apresentados os indicadores referentes à dimensão público interno. 
TABELA 4.2 - Indicadores da dimensão público interno

\begin{tabular}{cl} 
CÓDIGO & \multicolumn{1}{c}{ INDICADORES } \\
B5 & Condições de Trabalho \\
B6 & Benefícios Adicionais \\
B7 & Critérios de Contratação \\
B8 & Valorização da Diversidade \\
B9 & Pessoas com Necessidades Especiais \\
B10 & Relações com Sindicato \\
B11 & Desenvolvimento Profissional \\
B12 & Acesso à Informação \\
\hline
\end{tabular}

$O$ indicador condições de trabalho identifica se o Instituto, além de cumprir com as obrigações legais, monitora os planos e metas para ultrapassar os padrões de excelência em saúde, segurança e condições de trabalho do seu setor.

Por meio do indicador benefícios adicionais, busca-se avaliar se o Instituto fornece a seus funcionários benefícios diferenciados, que vão muito além daqueles exigidos por lei.

$O$ indicador critérios de contratação identifica se existem transparência e divulgação adequada das vagas em aberto. Verifica se existe um monitoramento com relação ao cumprimento dos requisitos estabelecidos na contratação de forma a exigir que sejam feitos ajustes que garantam o correto cumprimento da legislação.

O indicador valorização da diversidade considera se o Instituto, no momento de seleção e contratação de pessoal, está isento de práticas discriminatórias com relação a gênero, raça, orientação sexual, idade, crenças religiosas ou politicas, bem como pessoas com deficiência.

$O$ indicador pessoas com necessidades especiais avalia se o Instituto conta com recursos de acessibilidade para facilitar o deslocamento e a convivência de pessoas com qualquer tipo de deficiência.

$O$ indicador relações com sindicato leva em conta se o Instituto exerce algum tipo de pressão e se oferece liberdade para a atuação dos sindicatos no local de trabalho.

$O$ indicador desenvolvimento profissional identifica se o Instituto mantém atividades sistemáticas de desenvolvimento e capacitação destinadas ao 
aperfeiçoamento contínuo de todo seu pessoal, considerando a aplicabilidade em sua função atual.

O indicador acesso à informação verifica se o Instituto facilita o acesso às informações sobre o histórico da instituição: sua missão, visão, políticas, organograma, mercados, principais parceiros, clientes etc., como forma de desenvolvimento pessoal e profissional de seus funcionários.

\subsubsection{Meio Ambiente}

Conhecer o impacto da atividade da empresa no meio ambiente é um dos requisitos para uma gestão responsável. Para isso, é fundamental monitorar e analisar os impactos ambientais de seus produtos e serviços, desenvolver processos de gestão ambiental, acompanhar seus efeitos, inclusive na cadeia produtiva, e participar de processos de destinação final e pós-consumo (WEINGRILL, 2003).

O alcance dos compromissos com as questões ambientais também pode ser avaliado a partir da sua inclusão no planejamento estratégico das organizações e na introdução da educação ambiental na agenda de obrigações sociais (BELLEN, 2005; WEINGRILL, 2003).

Com base nestas questões ambientais, formulou-se a seguinte hipótese:

H3: Há uma relação positiva entre a dimensão meio ambiente e a responsabilidade social.

Para essa dimensão, os itens da escala selecionados foram baseados nos trabalhos do Instituto Ethos de Responsabilidade Social, e a arquitetura desses indicadores foi fundamentada na proposta da BSD Consulting (CUSTODIO e MOYA, 2007; BSD CONSULTING, 2012). Na TAB.4.3 são apresentados os indicadores referentes à dimensão meio ambiente.

TABELA 4.3 - Indicadores da dimensão meio ambiente

C13 Gerenciamento de impactos

C14 Qualidade Ambiental

C15 Educação e Conscientização Ambiental 
O indicador gerenciamento de impactos avalia se o Instituto, além de cumprir a obrigação legal, conhece e desenvolve ações para prevenir os principais impactos ambientais causados por seus processos, produtos ou serviços e se realiza regularmente atividades de controle e monitoramento.

O indicador qualidade ambiental considera não somente critérios legais, mas leva em conta se o Instituto desenvolve programas internos de melhoramento ambiental, prioriza políticas preventivas e possui área ou comitê responsável pelo meio ambiente.

O indicador educação e conscientização ambiental verifica se o Instituto desenvolve sistematicamente atividades de educação ambiental focadas no público interno, seus familiares, fornecedores, clientes e comunidade do entorno. Também verifica se o Instituto disponibiliza informações, promove discussões e desenvolve campanhas de conscientização e educação ambiental.

\subsubsection{Fornecedor}

A relação que uma empresa estabelece com os seus fornecedores pode revelar o seu grau de comprometimento com a responsabilidade social. O primeiro passo para reforçar esse compromisso é estabelecer critérios rigorosos de seleção de fornecedores, tais como: exigir a reprodução das práticas de responsabilidade social e monitorar o seu cumprimento periodicamente, incluir exigências relativas ao cumprimento da legislação trabalhista, previdenciária e fiscal, além de estabelecer critérios para proibir práticas de discriminação, de forma a garantir a criação de um círculo de parceiros éticos (WEINGRILL, 2003).

Com base nessas ações de parceria com o fornecedor, formulou-se a seguinte hipótese:

H4: Há uma relação positiva entre a dimensão fornecedor e a responsabilidade social.

Para essa dimensão, os itens da escala selecionados, utilizaram as publicações do Instituto Ethos de Responsabilidade Social (CUSTODIO e MOYA, 2007). Na TAB.4.4 são apresentados os indicadores referentes à dimensão fornecedor. 
TABELA 4.4 - Indicadores da dimensão fornecedor

\begin{tabular}{cl} 
CÓDIGO & \multicolumn{1}{c}{ INDICADORES } \\
\hline D16 & Seleção de Fornecedores \\
D17 & Empregados dos Fornecedores \\
D18 & Responsabilidade Social dos Fornecedores \\
D19 & Apoio ao Desenvolvimento dos Fornecedores \\
\hline
\end{tabular}

O indicador seleção de fornecedores leva em consideração se o Instituto, em um processo de contratação, além de cumprir as exigências da legislação trabalhista, previdenciária e fiscal, também inclui critérios da avaliação específicos de responsabilidade social como: a proibição de trabalho infantil, relações de trabalho adequadas e padrões ambientais.

$O$ indicador empregados dos fornecedores avalia se os empregados estão contratados dentro da legislação vigente e se há políticas formais que contribuam para a erradicação do trabalho forçado e infantil, exigindo dos seus fornecedores o cumprimento da legislação.

$O$ indicador responsabilidade social dos fornecedores verifica se o Instituto, além de colaborar para o crescimento de seus fornecedores de igual ou menor porte, estimula e facilita o seu envolvimento em projetos sociais e ambientais.

O indicador apoio ao desenvolvimento dos fornecedores avalia se o Instituto negocia com transparência, se disponibiliza informações, se promove atividades conjuntas, se mantém relações duradouras e se contribui com seu crescimento.

\subsubsection{Cliente}

O cuidado no tratamento dado aos consumidores, a busca de soluções para problemas e assimilação de sugestões compõem um quadro que pode colaborar para o aperfeiçoamento de suas ações no que diz respeito à responsabilidade social. Essas ações devem ser rápidas e eficazes, utilizando as informações para melhorar a qualidade de seus produtos e serviços e atuar de maneira proativa. O marketing e a comunicação das empresas não podem se dissociar da preocupação com a responsabilidade social. Essa preocupação deve 
se basear na coerência de suas ações, na criação de valores para a sociedade e na comunicação destes valores. (WEINGRILL, 2003).

Um passo importante para a criação de uma cultura ética e socialmente responsável com os consumidores e clientes é conhecer os efeitos benéficos e nocivos dos produtos e acompanhar o impacto de suas atividades na sociedade. É importante realizar estudos e pesquisas técnicas sobre riscos potenciais desses produtos, divulgando essas informações para os parceiros comerciais e adotando medidas preventivas ou corretivas. Por fim, uma importante medida é a atualização tecnológica, com a substituição de tecnologias e produtos na medida em que surgirem outros mais eficientes, seguros e com menos riscos (WEINGRILL, 2003).

Com base nessas ações formulou-se a seguinte hipótese:

H5: Há uma relação positiva entre a dimensão cliente e a responsabilidade social.

Para essa dimensão, os itens da escala elaborados neste estudo tiveram como referência os trabalhos do Instituto Ethos de Responsabilidade Social e alguns conceitos de Clarkson (CUSTODIO e MOYA, 2007; CLARKSON, 1995). $\mathrm{Na}$ TAB.4.5 são apresentados os indicadores referentes à dimensão cliente.

TABELA 4.5 - Indicadores da dimensão cliente

\begin{tabular}{cl} 
CÓDIGO & \multicolumn{1}{c}{ INDICADORES } \\
E20 & Excelência de Atendimento \\
E21 & Dúvidas, Sugestões e Reclamações \\
E22 & Satisfação dos Clientes \\
E23 & Política de Comunicação Comercial \\
E24 & Gerenciamento de Danos Potenciais \\
\hline
\end{tabular}

O indicador excelência de atendimento avalia se o Instituto disponibiliza canais eficientes de comunicação com seus clientes e se tais canais são de fato lidos, entendidos e processados de maneira adequada.

O indicador dúvidas, sugestões e reclamações avalia se o Instituto disponibiliza um canal de comunicação pelo qual o cliente possa manifestar suas 
dúvidas, sugestões e reclamações e se essas manifestações são registradas e comunicadas internamente. Também avalia se essas manifestações são utilizadas como um instrumento para aperfeiçoamento das atividades do Instituto.

O indicador satisfação do cliente avalia se o instituto realiza pesquisas de satisfação junto ao cliente e se os resultados das pesquisas são tomados como base para programar melhorias em seus produtos e serviços.

O indicador política de comunicação comercial identifica se o Instituto possui um canal aberto de comunicação com seus clientes e se possui uma política formal de comunicação alinhada com seus valores e princípios, abrangendo todo o seu material de comunicação tanto interno quanto externo. Esse indicador também avalia se o Instituto tem procedimentos específicos para que sua comunicação possibilite a criação de valores positivos na sociedade como forma de contribuir para o desenvolvimento sustentável.

$O$ indicador gerenciamento de danos potenciais avalia se o Instituto realiza regularmente estudos e pesquisas técnicas sobre os riscos potenciais de seus produtos e serviços e se adota medidas corretivas e preventivas quando detecta riscos à saúde e à segurança de seus clientes. Também avalia se há politicas de aperfeiçoamento contínuo dos produtos e serviços, substituindo tecnologias e procedimentos, quando necessário.

\subsubsection{Comunidade}

Segundo Weingrill (2003), um ponto importante a ser tratado pela empresa em sua relação com a comunidade é o impacto produzido por suas atividades. É necessário conhecer os impactos, possuir processos estruturados e sistemáticos para divulgar, registrar e monitorar as atividades e também acatar queixas e reclamações. É interessante promover reuniões com lideranças locais, pois envolver a comunidade na resolução de problemas cria laços sólidos e duradouros.

O diálogo, as parcerias de longo prazo, os projetos para fortalecimento das parcerias e os programas sociais estruturados com organizações atuantes na comunidade podem abrir caminhos estratégicos e reduzir conflitos decorrentes das atividades das empresas e entidades locais (WEINGRILL, 2003).

As ações sociais das empresas para com a comunidade devem ter consistência, objetivos claros e estar alinhados com o planejamento estratégico. 
O alinhamento das atividades da empresa com sua ação social demonstra a coerência estratégica da organização. Esse envolvimento pode ser financeiro ou por meio de recursos humanos, espaços, equipamentos, competências técnicas, tecnologias e até no envolvimento de funcionários parceiros das empresas no desenvolvimento e implantação dos projetos sociais (WEINGRILL, 2003).

Com base nessas práticas, formulou-se a seguinte hipótese:

H6: Há uma relação positiva entre a dimensão comunidade e a responsabilidade social.

Para essa dimensão, os itens da escala elaborados nessa dissertação tiveram como referência os trabalhos do Instituto Ethos de Responsabilidade Social e alguns conceitos utilizados no livro de Rosa Maria Fisher (CUSTODIO e MOYA, 2007; FISHER, 2002). Na TAB.4.6 são apresentados os indicadores referentes à dimensão comunidade.

TABELA 4.6 - Indicadores da dimensão comunidade

\begin{tabular}{cl} 
CÓDIGO & \\
F25 & Impacto na Comunidade do Entorno \\
F26 & Relacionamento com a Comunidade de Entorno \\
F27 & Estímulo ao Trabalho Voluntário \\
F28 & Envolvimento da Empresa em Ação Social \\
F29 & Relações com Entidades Beneficiadas \\
F30 & Participação Comunitária \\
F31 & Benefícios para o Negócio \\
\hline
\end{tabular}

O indicador impacto na comunidade do entorno avalia se o Instituto se preocupa em estar sempre em contato com a comunidade do entorno procurando minimizar os impactos negativos que suas atividades possam causar.

O indicador relacionamento com a comunidade do entorno analisa se 0 Instituto possui uma política formal de relacionamento com a comunidade, se mantém comitês permanentes ou grupos de trabalho com a participação de lideranças locais para analisar suas atividades e monitorar seus impactos.

O indicador estímulo ao trabalho voluntário identifica se o Instituto incentiva o trabalho voluntário de seus funcionários na comunidade. 
O indicador envolvimento da empresa em ação social avalia se 0 Instituto apoia entidades com doações, financiamentos e implementação de projetos, divulgando experiências bem-sucedidas.

$\mathrm{O}$ indicador relações com entidades beneficiadas avalia 0 relacionamento do Instituto com entidades por ele beneficiadas, deixando claro para todas as partes a responsabilidade de cada um nessa parceria.

A participação comunitária analisa como o Instituto atua no gerenciamento de seus negócios ao optar por apoiar uma determinada entidade ou projeto e também verifica se busca algum tipo de conciliação entre seus interesses e os interesses da comunidade.

$\mathrm{O}$ indicador benefícios para o negócio checa até que ponto o Instituto acredita que suas ações junto à comunidade significam um dos fatores importantes para o bom andamento de seus negócios.

\subsubsection{Governo e Sociedade}

O envolvimento das empresas com o poder público deve refletir os princípios éticos que regem essa relação, principalmente no que se refere à proibição de práticas corruptas. As empresas devem evitar situações que envolvam o favorecimento de agentes do poder público, devem possuir normas escritas e divulgadas amplamente sobre o tema e manter procedimentos formais de controle, punição e auditoria (WEINGRILL, 2003).

A atuação politica das empresas também pode ocorrer na defesa dos seus próprios interesses ou de causas de caráter público. É importante que as organizações tenham a participação em comissões e grupos de trabalho relacionados com a defesa e promoção de interesses específicos e públicos. A elaboração de propostas de caráter social e o seu acompanhamento pelas autoridades públicas representam, de forma prática, como as empresas podem se caracterizar como agentes de transformação social (WEINGRILL, 2003).

Com base nessas práticas, formulou-se a seguinte hipótese:

H7: Há uma relação positiva entre a dimensão governo e sociedade e a responsabilidade social. 
Para essa dimensão, os itens da escala elaborados pela autora desse estudo tiveram como referência os trabalhos do Instituto Ethos de Responsabilidade Social (CUSTODIO e MOYA, 2007). Na TAB.4.7 são apresentados os indicadores referentes à dimensão governo e sociedade.

TABELA 4.7 - Indicadores da dimensão governo e sociedade

\begin{tabular}{cl} 
CÓDIGO & \multicolumn{1}{c}{ INDICADORES } \\
\hline G32 & Participação e Influência Sindical \\
G33 & Envolvimento em Campanhas Políticas \\
G34 & Participação em Administrações Públicas \\
G35 & Espaços Públicos \\
\hline
\end{tabular}

O indicador participação e influência sindical avalia se o Instituto discute com outros Institutos suas necessidades e formas de mobilização em busca de melhores condições tanto do Instituto quanto da sociedade.

$O$ indicador envolvimento em campanhas políticas analisa quão ético é o Instituto com relação ao seu envolvimento em campanhas políticas.

$O$ indicador participação em administrações públicas verifica se o instituto participa de comissões e grupos de trabalho relacionados às questões de interesse público. Analisa, também, se o Instituto participa de processos de elaboração de propostas de interesse público e de caráter socioambiental, contribuindo com recursos humanos ou financeiros.

$O$ indicador espaços públicos verifica se o Instituto colabora com a melhoria dos espaços públicos de sua região, tais como: escolas, postos de saúde, praças, áreas verdes etc.

\subsubsection{Contribuição do modelo teórico proposto}

A principal contribuição desse estudo é o desenvolvimento de um modelo que integra as dimensões da responsabilidade social. O modelo teórico proposto nesse trabalho inclui constructos previamente utilizados em vários contextos dessa pesquisa empírica, assim como constructos desenvolvidos a partir da revisão da teoria sobre os conceitos de responsabilidade social.

A TAB.4.8 destaca os modelos encontrados na revisão da literatura. Esses modelos foram concebidos a partir de discussões sobre o tema e participaram de 
um processo evolutivo. A partir daí foram surgindo novos modelos cada vez mais adequados às novas situações. O modelo teórico proposto combina os principais aspectos de cada um dos modelos estudados e procura gerar um novo modelo completo, porém mais simples.

TABELA 4.8 - Metodologias e indicadores socioambientais

\begin{tabular}{crll} 
País & Ano & \multicolumn{1}{c}{ Metodologias de Mensuração da Responsabilidade Social } \\
\hline U.S.A. & 1995 & $\begin{array}{l}\text { Indicadores de Desenvolvimento sustentável da Organização das Nações } \\
\text { Unidas }\end{array}$ \\
U.S.A. & 1997 & Global Reporting Initiative (GRI) \\
U.S.A. & 1998 & Painel de Controle da Sustentabilidade \\
U.S.A. & 1999 & Índice Dow Jones de Sustentabilidade \\
França & 2000 & Barômetro de Sustentabilidade \\
Inglaterra & 2002 & $\begin{array}{l}\text { Métricas de Sustentabilidade do Institution of Chemical Engineers } \\
\text { (IChemE) }\end{array}$ \\
Brasil & 2002 & Indicadores Ethos de Responsabilidade Social \\
Brasil & 2007 & Metodologia Tear - Tecendo Redes Sustentáveis \\
U.S.A. & 2007 & Triple Bottom Line \\
U.S.A. & 2011 & Global Compact \\
\hline
\end{tabular}

Uma vez apresentados o modelo teórico e as hipóteses de pesquisa, o próximo passo é descrever o método utilizado na etapa empírica ${ }^{19}$ do estudo. Essa descrição será apresentada no item a seguir.

\subsection{Metodologia da pesquisa empírica}

Marconi e Lakatos (2003) definem o modelo de pesquisa como um conjunto de atividades sistemáticas e racionais que permitem alcançar o objetivo definido para a investigação, traçando o caminho a ser seguido, detectando erros e auxiliando as decisões do pesquisador.

\footnotetext{
${ }^{19}$ A pesquisa empirica é a aquisição de dados a partir de fontes diretas (pessoas) que conhecem, vivenciaram ou têm conhecimento sobre o tema, fato ou situação e que podem causar diferenciação na abordagem e entendimento dos mesmos, conduzindo a uma mudança, acréscimo ou alteração profunda, relevante, que não distorça, agrida ou altere o conteúdo principal, mas que o enriqueça e transforme em conhecimento de fácil compreensão (VIEIRA, 1999).
} 
Para as ciências sociais, grande parte das medições realizadas fornecem resultados que são, até certo ponto, pouco confiáveis. Isso acontece porque os constructos de interesse das ciências sociais e comportamentais tipicamente representam abstrações como, por exemplo, motivação e personalidade, que precisam ser medidas indiretamente (ONWUEGBUZIE e LEECH, 2005).

Com base nessa constatação, deriva-se a ideia de que os investigadores devam assumir uma postura pragmática com relação à pesquisa de campo, abandonando a polarização entre os métodos qualitativos e quantitativos. Em geral, o objetivo da pesquisa qualitativa é o lançamento e a construção de teorias, enquanto a quantitativa pretende tipicamente testar ou modificar a teoria (ONWUEGBUZIE e LEECH, 2005).

Os métodos de pesquisa quantitativa, de modo geral, são utilizados quando se quer medir opiniões, reações, sensações, hábitos, atitudes de um universo (público-alvo) por meio de uma amostra que o represente de forma comprovada estatisticamente. Isto não significa que ela não possa ter indicadores qualitativos. Desde que o estudo permita, isso sempre é possível (VIEIRA, 1999).

Segundo Vieira (1999), há, no mínimo, dois importantes tipos de pesquisa: a descritiva e a experimental.

A pesquisa descritiva observa, registra, analisa e correlaciona fatos ou fenômenos (variáveis) sem manipulá-los. Procura descobrir, com precisão possível, a frequência com que um fenômeno ocorre, sua relação e conexão com outros, sua natureza e características. Busca conhecer as diversas situações e relações que ocorrem na vida social, política, econômica e demais aspectos do comportamento humano, tanto do indivíduo tomado isoladamente como de grupos e comunidades mais complexas. Por ocorrerem em seu hábitat natural, os dados, precisam ser coletados e registrados ordenadamente para seu estudo propriamente dito.

A pesquisa experimental caracteriza-se por manipular diretamente as variáveis relacionadas com o objeto de estudo. Nesse tipo de pesquisa, a manipulação das variáveis proporciona o estudo da relação entre causas e efeitos de um determinado fenômeno. Nesse tipo de pesquisa, interfere-se diretamente na realidade, manipulando-se a variável independente a fim de se observar o que acontece com a dependente. 
Tendo em vista os conceitos acima descritos e a complexidade do tema escolhido para este estudo, a abordagem metodológica escolhida foi a pesquisa descritiva quantitativa, que foi aplicada aos funcionários do IPEN.

\subsubsection{Validação do instrumento de coleta de dados}

O instrumento de mensuração passou por uma avaliação de sua validade de conteúdo, por meio da qual se procurou observar a adequação dos itens presentes com base na teoria e no objetivo deste trabalho (TULL e HAWKINS, 1990). Por não haver um teste estatístico formal para medir a validade de conteúdo, recomenda-se utilizar o julgamento e as percepções do pesquisador e de pessoas especialistas na área (GARVER e MENTZER, 1999).

Inicialmente, os itens propostos para cada dimensão da responsabilidade social foram discutidos com a orientadora. Em busca de opiniões externas, as primeiras versões do questionário foram submetidas à avaliação de professores e alunos de mestrado e doutorado durante o curso de Técnicas de Levantamento e Análise de dados, ministrado na FEA, que tem como um dos principais objetivos ensinar os aluno a realizar uma pesquisa acadêmica.

Segundo Churchill (1983), é interessante, na medida do possível, buscar a simplicidade e facilidade de entendimento das perguntas do questionário, evitando termos técnicos ou ambíguos para não incorrer em problemas como não resposta e erros de mensuração atribuíveis a uma compreensão errada das frases.

Hair, Black, Babin, Anderson e Tatham (2006) sugerem que, quando os itens do instrumento de mensuração são desenvolvidos especificamente para um estudo ou derivam de diversas fontes, algum tipo de pré-teste deve ser realizado com respondentes similares ao público- alvo do estudo.

Uma vez formulado, o questionário foi submetido a um pré-teste, que será descrito a seguir. No entanto, esse questionário, por não ser a versão final, não será apresentado no trabalho.

\subsubsection{Pré-Teste}

O questionário elaborado para a realização da pesquisa foi aplicado como um pré-teste para todos os funcionários do Centro de Engenharia Nuclear 
$\left(\mathrm{CEN}^{20}\right)$. O CEN foi escolhido por ser um departamento com um volume significativo de funcionários, de várias áreas de pesquisa em engenharia nuclear, no qual a média de tempo de trabalho de cada um na instituição é de aproximadamente 20 anos.

O questionário foi impresso e deixado sobre a mesa de cada funcionário presente no dia da pesquisa. O CEN possui 80 funcionários e, no dia da realização da pesquisa, foram entregues 45 questionários.

Dessa amostra, 34 questionários foram respondidos e analisados. Porém, 30 respondentes foram considerados para as análises univariada ${ }^{21} \mathrm{e}$ multivariada $^{22}$.

Antes de iniciar o trabalho de análises estatísticas do pré-teste, foram verificados os dados colhidos em campo e retirados do banco de dados os casos nos quais houve preenchimento parcial do questionário ou inconsistências nas respostas. Seguindo a indicação de Hair et al. (2006), foram eliminados os questionários com mais de $15 \%$ de respostas em branco. Em seguida, foram excluídos os casos em que houve problemas com o preenchimento, como respostas repetidas com frequência. Assim, quatro questionários que estavam nas condições acima descritas foram eliminados da análise.

\section{Análise univariada do pré-teste}

A análise univariada descritiva da amostra compreende a caracterização do perfil do respondente, que considerou sexo, grau de instrução, tempo de instituição, função e idade. As tabelas abaixo representam os resultados da análise univariada realizada no pré-teste (TAB.4.9, TAB.4.10, TAB.4.11, TAB.4.12 e TAB.4.13).

\footnotetext{
${ }^{20} \mathrm{O}$ Centro de Engenharia Nuclear (CEN) é uma unidade técnico-administrativa do Instituto de Pesquisas Energéticas e Nucleares da Comissão Nacional de Energia Nuclear (IPEN/CNEN-SP). As principais atividades do CEN são a atuação em pesquisa, desenvolvimento, ensino, serviços e consultoria especializada (IPEN - INTRODUÇÃO AO CEN, 2012).

${ }^{21}$ Análise Univariada dos dados coletados constitui um exame da sua distribuição, considerando apenas uma variável ou característica (SCHARADER, 1978).

${ }^{22}$ Análise Multivariada examina simultaneament duas ou mais variáveis (MALHOTRA, 2006).
} 
TABELA 4.9 - Sexo (pré-teste)

\begin{tabular}{|c|c|c|}
\hline \multicolumn{3}{|c|}{ Sexo } \\
\hline & Frequência & Percentual \\
\hline Masculino & 21 & $70 \%$ \\
\hline Feminino & 9 & $30 \%$ \\
\hline Total & 30 & $100 \%$ \\
\hline \multicolumn{3}{|c|}{ TABELA 4.10 - Grau de instrução (pré-teste } \\
\hline \multicolumn{3}{|c|}{ Grau de Instrução } \\
\hline & Frequência & Percentual \\
\hline Ensino superior & 6 & $20 \%$ \\
\hline Pós -Graduação & 24 & $80 \%$ \\
\hline Total & 30 & $100 \%$ \\
\hline
\end{tabular}

TABELA 4.11 - Tempo de instituição (pré-teste)

\begin{tabular}{|c|c|c|}
\hline \multicolumn{3}{|c|}{ Tempo } \\
\hline & Frequência & Percentual \\
\hline 2 a 10 anos & 5 & $17 \%$ \\
\hline 11 a 20 anos & 3 & $10 \%$ \\
\hline 21 a 30 anos & 15 & $50 \%$ \\
\hline Acima de 30 & 7 & $23 \%$ \\
\hline Total & 30 & $100 \%$ \\
\hline \multicolumn{3}{|c|}{ TABELA 4.12 - Função (pré-teste) } \\
\hline \multicolumn{3}{|c|}{ Função } \\
\hline & Frequência & Percentual \\
\hline Administrativa & 1 & $3 \%$ \\
\hline Estudante & 2 & $7 \%$ \\
\hline Gestor & 4 & $13 \%$ \\
\hline Pesquisador & 23 & $77 \%$ \\
\hline Total & 30 & $100 \%$ \\
\hline
\end{tabular}

TABELA 4.13 - Idade (pré-teste)

\begin{tabular}{lcc} 
& Idade & \\
& Frequência & Percentual \\
$\mathbf{2 5}$ a $\mathbf{3 0}$ anos & 3 & $10 \%$ \\
$\mathbf{3 1}$ a $\mathbf{4 0}$ anos & 0 & $0 \%$ \\
$\mathbf{4 1}$ a $\mathbf{5 0}$ anos & 6 & $20 \%$ \\
$\mathbf{5 1}$ a 60 anos & 16 & $53 \%$ \\
Acima de 60 & 5 & $17 \%$ \\
\hline Total & $\mathbf{3 0}$ & $\mathbf{1 0 0 \%}$ \\
\hline
\end{tabular}




\section{Análise multivariada do pré-teste}

A análise multivariada realizada com a amostra do pré-teste foi a análise de confiabilidade das escalas. A confiabilidade das escalas foi avaliada por meio do coeficiente Alfa de Cronbach. Informações sobre esse coeficiente são detalhadas no item 4.2.3.3 Metodologia de Análise de Dados - análise multivariada - item um. Pelas recomendações de Hair et al. (2006), o Alfa de Cronbach é aceitável para valores maiores que 0,60.

Para todos os constructos analisados no pré-teste, ou seja, para todas as dimensões, observou-se um valor de Alfa de Cronbach acima do que diz a literatura, exceto a dimensão Governo e Sociedade, que apresentou um valor de 0,497, que é menor do que o de 0,60 sugerido pela literatura. $O$ item que deu origem ao problema foi a questão "O Instituto é criterioso sobre seu envolvimento em campanhas políticas". Uma possível explicação para esse problema deriva do fato de que os funcionários públicos federais não podem propagar ativamente e abertamente suas preferências políticas dentro do IPEN. Isso muitas vezes inibe o funcionário de se envolver em campanhas políticas, com receio de futuras retalhações legais. $O$ item com correlação inadequada foi retirado por não conformidade e calculou-se novamente o Alfa de Cronbach para a dimensão. 0 novo resultado evoluiu de 0,497 para 0,762.

Os resultados dos testes de confiabilidade da escala por meio do Alfa de Cronbach, após a retirada da questão problema, são apresentados na TAB.4.14.

TABELA 4.14 - Análise de Confiabilidade

\begin{tabular}{lc}
\hline \multicolumn{2}{c}{ Alfas de Cronbach } \\
\hline Dimensões & Alfa de Cronbach \\
\hline Ética & 0,776 \\
Público Interno & 0,764 \\
Meio Ambiente & 0,806 \\
Fornecedores & 0,876 \\
Clientes e Consumidores & 0,737 \\
Comunidade & 0,859 \\
Governo e Sociedade & 0,762 \\
\hline TOTAL & 0,913 \\
\hline
\end{tabular}




\section{Resultados do pré-teste}

No pré-teste sobre a avaliação da responsabilidade social do IPEN pelos funcionários do CEN, a dimensão público interno foi a melhor pontuada, e as dimensões fornecedor e comunidade tiveram a pontuação mais baixa. Numa escala de 1 a 6 , onde 1 significa o menor grau de responsabilidade social e 6 o maior grau de responsabilidade social, o CEN atingiu uma média de 2,9 pontos.

Na FIG.4.5 é mostrado o resultado da pontuação das dimensões que visam mensurar a responsabilidade social do IPEN.

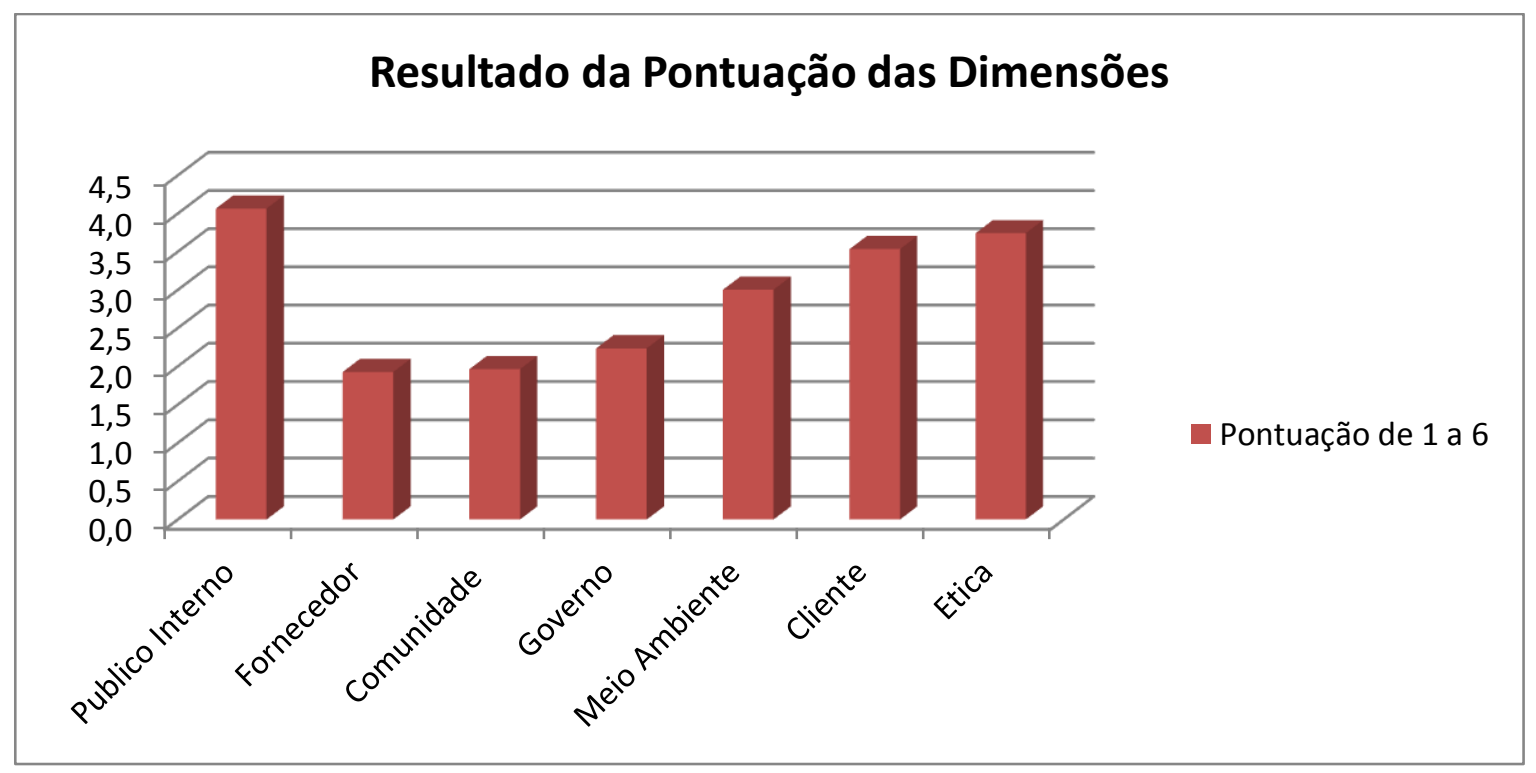

FIGURA 4.5 - Resultado da pontuação das dimensões da Responsabilidade Social (pré-teste)

\section{Conclusões do pré-teste}

Segundo Schader (1978), o objetivo de um pré-teste no instrumento de coleta de dados é controlar a efetividade da mensuração. Para Selltiz et al. (1959, p.82), "muitas dificuldades poderiam ser evitadas por um pré-teste cuidadoso das técnicas empregadas a fim de se ter certeza de que fornecerão informações necessárias.". Malhotra (2006) recomenda realizar os pré-testes com uma amostra de 15 a 30 pessoas, dependendo da heterogeneidade da população, e analisar as respostas obtidas para checar se o problema foi adequadamente definido. O pré-teste serve também para verificar se os dados e as análises 
estatísticas planejadas mostram-se aptos para fornecer as informações desejadas.

Após a realização do pré-teste e da execução de todas as análises acima descritas, as questões foram revisadas e aquelas referentes à dimensão governo e sociedade (que obtiveram um Alfa de Cronbach abaixo do recomendado na literatura) foram reescritas para melhor entendimento dos respondentes. Além disso, em cada item do questionário foi inserida uma breve explicação da escala utilizada para cada uma das afirmações.

\subsubsection{Definição do instrumento de coleta de dados}

A versão final do instrumento de pesquisa resultou em 35 indicadores observáveis, configurando no mínimo três itens para cada variável latente das dimensões da responsabilidade social, de acordo com as recomendações de Hair et al. (2006, p.786), que indica que constructos com menos de 3 variáveis devem ser evitados.

O questionário contém sete blocos de questões. O primeiro, que se refere à ética, foca em valores, transparência e governança cultivados pelo IPEN. O segundo apresenta questões sobre a atuação do IPEN diante do seu público interno, considerando a percepção do respondente com relação a essa atuação. O terceiro foca suas questões na percepção do respondente quanto à atuação do IPEN frente às ações voltadas para o meio ambiente. O quarto questiona sobre as ações do IPEN no relacionamento com seus fornecedores. $O$ quinto se refere às ações do IPEN perante seus clientes. O sexto tem questões referentes à comunidade do entorno e o sétimo aborda a sua participação no governo e na sociedade.

Existem várias escalas que são utilizadas em questionários para se medir o comportamento e opinião das pessoas e dentre as mais utilizadas podemos citar (CUNHA, 2007):

as escalas tipo Thurstone, que são constituídas por um conjunto de frases (itens) em relação às quais o avaliado deve manifestar o seu acordo ou desacordo; 
exemplo: faça um (v) se concordar com a frase ou faça um (x) se discordar da frase.

( ) gosto da minha igreja por que há lá um espírito de amizade.

( ) acho que a igreja é um parasita da sociedade.

as escalas tipo Guttman ou cumulativa que é composta por um conjunto de frases (itens) organizados de forma hierárquica e em relação aos quais se pede ao avaliado que manifeste a sua concordância ou discordância;

exemplo: para cada grupo indicado, ponha tantas cruzes quantas as que as suas reações imediatas Ihe ditarem.

casaria com um membro deste grupo

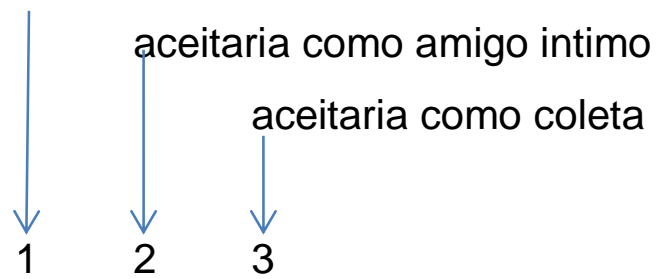

Inglês

Francês

() $\quad\left(\begin{array}{ll}() & ()\end{array}\right.$

Brasileiro

as escalas do tipo Diferenciador Semântico, que é composta por um conjunto de pares de adjetivos com significados o mais opostos possíveis, entre os quais se estabelece uma escala de sete pontos onde é pedido ao avaliado que assinale na referida escala o que sente relativamente ao objeto de estudo para cada par de adjetivos.

exemplo: pretendemos saber qual sua opinião sobre a polícia e pedimos para assinalar a sua posição nos espaços que estão entre os dois pontos.

\section{POLÍCIA}

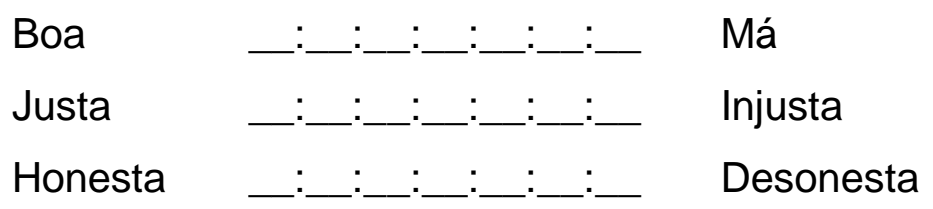

as escalas do tipo Likert, que é composta por um conjunto de frases (itens) em relação a cada uma das quais se pede ao avaliado para manifestar o 
grau de concordância desde o discordo totalmente (nível 1) até o concordo totalmente (nível 5, 6, 7 podendo chegar até 11).

exemplo: para cada uma das frases (itens) abaixo, indique o seu grau de concordância, utilizando a seguinte escala: 1-concordo totalmente; 2-concordo; 3-nem concordo nem discordo; 4-discordo; 5-discordo totalmente.

( ) grande parte do que se diz acerca da crise ecológica que o mundo atravessa é exagerado e alarmista.

( ) os males provocados pela construção de uma central nuclear no nosso país não compensam os seus eventuais benefícios.

A escala de Likert é utilizada comumente em pesquisas e questionários auto respondidos. Muitas vezes utiliza-se para medir atitudes dos inquiridos, permite que participantes qualifiquem o quanto concordam com uma declaração específica em uma escala numérica. Cada um desses números é um "item Likert" e, geralmente, são classificados a partir de "concordo plenamente" até "discordo plenamente", com muitos intervalos de concordância entre eles. Existem escalas de Likert que variam de quatro a onze categorias, mas as escalas de quatro e cinco categorias são as mais populares (JOHNSON, 2002).

Essa escala pode conter uma quantidade de itens pares ou ímpares. A utilização de uma escala par, sem um item central, pode conduzir a uma tendência e forçar os respondentes a marcarem a direção a que eles estão "inclinados". Um problema com a categoria do meio em uma escala ímpar é que o respondente tende a selecionar essa resposta, quando não sabe ou não tem experiência. Pessoas confundem a categoria neutra como "não sei" ou "não aplico" (AKINS, 2002).

A escala utilizada no questionário deste trabalho é do tipo Likert, ou seja, intervalar assumida, onde se solicita que os respondentes assinalem os números de 1 a 6, correspondendo a notas indicativas do grau de importância, de concordância ou discordância, conhecimento ou desconhecimento em cada frase, pressupondo intervalos iguais entre cada nota. $O$ fato da escala adotada ser par impede a neutralidade, ou seja, impede que os respondentes marquem a coluna do meio, como forma de não posicionamento perante uma determinada questão. Lakatos e Marconi (2003), assim como Churchill (1983), admitem que as 
respostas numéricas que trazem embutido um julgamento sobre o item por meio de uma escala são organizadas em graus de intensidade crescente, por este motivo, a escala Likert se mostrou a mais adequada para o questionário deste trabalho.

Os itens de uma escala são uma maneira de acessar um constructo, e o ponto escolhido da escala pelo respondente é, na verdade, a medida que evidencia o quanto o constructo se refere ao fenômeno que está na mente da pessoa (EDWARDS e BAGOZZI, 2000).

Em função dos objetivos do estudo de campo, a saber, mensurar diretamente opiniões dos respondentes sobre responsabilidade social, realizou-se um survey - método de investigação que se caracteriza pelo questionamento dos participantes acerca de suas percepções, motivações, conhecimentos e opiniões, utilizando o questionário estruturado como instrumento de coleta de dados (CHURCHILL, 1983; MALHOTRA, 2006).

O questionário elaborado foi do tipo estruturado, formal, com perguntas fechadas para ser preenchido diretamente pelos respondentes. O questionário de autopreenchimento não exige a identificação dos indivíduos, o que é conveniente quando se trata de um tema complexo e sensível, pois permite maior liberdade nas respostas em razão do anonimato (MARCONI e LAKATOS, 2003). Esse tipo de instrumento também oferece menores riscos de distorção, pois não existe a influência do pesquisador e, ao mesmo tempo, a avaliação tende a ser mais uniforme em virtude da natureza impessoal do instrumento.

O questionário pode ser encontrado em sua versão integral no APÊNDICE A.

Após a elaboração do questionário, a etapa seguinte foi o estudo conclusivo descritivo, caracterizado pela coleta e análise de dados quantitativos.

\subsubsection{Estudo conclusivo, descritivo e quantitativo}

O objetivo do estudo conclusivo descritivo é realizar a verificação quantitativa para testar as hipóteses específicas e examinar as relações entre as dimensões do constructo analisado. Segundo Mattar (2005), as pesquisas descritivas têm como finalidade descrever as características de grupos, estimar a parcela de elementos da população que possuem certos atributos ou comportamentos e verificar a existência de relações entre as variáveis. Utilizam- 
se os métodos estruturados em um grande número de casos avaliados e usa-se também a análise estatística dos dados para que se possa generalizar os resultados da amostra para a população de interesse do estudo (MALHOTRA, 2006).

Após a elaboração do questionário, explicada no item anterior, o passo seguinte foi definir a amostra para a realização da pesquisa e determinar a metodologia para a coleta e a análise dos dados.

\subsubsection{Definição da amostra utilizada na pesquisa}

De acordo com Malhotra (2006) amostra é um subgrupo dos elementos da população selecionada para participação no estudo. O processo de elaboração da amostragem é constituído de cinco etapas, que são definir a população alvo, determinar a composição da amostra, escolher as técnicas de amostragem, determinar o tamanho da amostra e executar o processo de amostragem.

População alvo é a coleção de elementos ou objetos que possuem a informação procurada pelo pesquisador e sobre os quais devem ser feitas inferências. A população alvo deve ser definida em termos de elementos, unidades amostrais, extensão e período (MALHOTRA, 2006).

A composição da amostra é uma representação dos elementos da população alvo. Consiste em uma lista ou conjunto de instruções para identificar a população alvo (MALHOTRA, 2006).

$\mathrm{Na}$ seleção da técnica da amostragem o pesquisador precisa decidir se utiliza a abordagem amostral tradicional ou bayesiana, amostragem com ou sem repetição e se trabalha com amostragem probabilística ou não probabilística (MALHOTRA, 2006).

A determinação do tamanho da amostra é a determinação do número de elementos que serão incluídos no estudo. A execução do processo de amostragem é a especificação detalhada de como serão implementadas as decisões sobre população, composição da amostra, unidade amostral, técnica de amostragem e tamanho da amostra (MALHOTRA, 2006).

A amostragem probabilística é o processo de amostragem em que cada elemento da população tem uma chance fixa de ser incluído na amostra. Segundo Malhotra (2006) as técnicas de probabilidade amostral se classificam com base em: 
amostragem de elementos versus amostragem por cluster;

probabilidade de unidades iguais versus estratificada;

seleção não estratificada versus estratificada;

seleção aleatória versus sistemática;

técnicas de estágio único versus de estágio múltiplo.

Segundo Malhotra (2006), amostragem não probabilística é a técnica que não utiliza seleção aleatória e que confia no julgamento pessoal do pesquisador. As técnicas de amostragem não probabilística incluem:

amostragem por conveniência onde a seleção das unidades amostrais é deixada a cargo do pesquisador;

amostragem por julgamento que consistem em uma amostragem por conveniência em que os elementos da população são selecionados deliberadamente com base no julgamento do pesquisador;

amostragem por cotas onde são desenvolvidas categorias ou quotas de controle de elementos da população, após são selecionados elementos da amostra com base na conveniência ou no julgamento do pesquisador;

amostragem bola de neve onde um grupo inicial é selecionado aleatóriamente e entrevistados subsequentes são selecionados com base em informações fornecidas pelos entrevistados iniciais.

Churchill (1983) ressalta que, quando a participação é voluntária ou os elementos da amostra são selecionados por serem convenientes, não se pode saber com certeza se são representativos em relação à população alvo.

Segundo Ghiglione e Matalon (1992), não existe qualquer método que assegure, em todos os casos, uma amostra absolutamente representativa. Os autores afirmam que:

"Se é necessário estarmos bem conscientes do problema, permanecer atento a estas dificuldades e não ficar facilmente satisfeito com o sorteio ou com o cumprimento das quotas é também indispensável evitar um purismo exagerado e condenar toda a sondagem por causa dos seus enviesamentos inevitáveis.". 
O quadro da força de trabalho do IPEN, composto por profissionais com cinco tipos de vínculos com a organização, está representado na TAB.4.15 (IPEN/CNEN, 2013).

TABELA 4.15 - Perfil da Força de Trabalho do IPEN

\begin{tabular}{lrc} 
Força de Trabalho & $\begin{array}{c}\text { Universo } \\
\text { Quantidade }\end{array}$ & \multicolumn{1}{c}{$\%$} \\
\hline Funcionários Públicos Federais & 951 & $39,1 \%$ \\
Comissionados & 3 & $0,1 \%$ \\
Terceirizados & 331 & $13,6 \%$ \\
Bolsistas e Estagiários & 1.114 & $45,7 \%$ \\
Trabalho Voluntário & 51 & $2,1 \%$ \\
\hline Total & $\mathbf{2 . 4 3 5}$ & $\mathbf{1 0 0 , 0 \%}$ \\
\hline
\end{tabular}

A amostra utilizada nessa pesquisa descritiva empírica é do tipo não probabilística. A pesquisa foi aplicada a todos os 951 funcionários do IPEN com participação voluntária.

\subsubsection{Metodologia de coleta de dados}

Os dados foram coletados via internet por meio de um questionário online elaborado na ferramenta de geração de formulário disponível no Google Drive via e-mail corporativo do IPEN.

O e-mail foi disparado no dia 14 de outubro de 2013 no período da manhã para todos os 951 funcionários do IPEN, e o período de coleta das respostas estendeu-se do dia 14 de outubro até 22 de novembro de 2013.

O e-mail enviado continha um texto explicativo sobre a pesquisa, seus objetivos, o nome da pesquisadora, de sua orientadora, o e-mail da pesquisadora para contato, agradecimento pela colaboração e um link para acessar o questionário hospedado no website da Google.

Abaixo é apresentado o link onde está hospedado o questionário. Para acessar é necessário copiar e colar o link no browser. O seu conteúdo pode ser encontrado no Apêndice A. 
Ao final do trabalho de coleta de dados 171 questionários foram recolhidos.. Esses questionários foram importados para o software MS-Excel e foram adaptados para estarem aptos a ser incluídos no trabalho de análise dos dados.

\subsubsection{Metodologia de análise de dados}

A análise dos dados quantitativos recolhidos foi realizada em duas principais etapas: (1) análise univariada e (2) análise multivariada. Em cada fase foram utilizadas técnicas específicas, detalhadas a seguir.

$\mathrm{O}$ processamento e análise dos dados colhidos foram realizados com a ajuda do software MS-Excel, o software estatístico Statistical Package for Social Sciences - Analysis of Moment Structures (SPSS AMOS) versão 20.0 e 0 o software estatístico Statistical Package for Social (SPSS) versão 20.0. Para as análises multivariadas foi utilizado o software SmartPLS versão 2.0.

O SPSS é um software estatístico para análise de dados utilizando técnicas estatísticas básicas e avançadas. Este software é largamente utilizado para fazer testes estatísticos, tais como correlação de variáveis e teste das hipóteses assumidas. Pode também proporcionar ao pesquisador contagens de freqüência, ordenar dados, reorganizar as informações e servir como um mecanismo de entrada de dados. O software SPSS-AMOS é um módulo à parte do SPSS e é utilizado para análise de Equações Estruturais (HAIR et al., 2006).

O SmartPLS é um software aplicativo para modelagem de caminhos com variáveis latentes (Latent Variables Path - LVP). Esse software utiliza o método de mínimos quadrados parciais (Partial Least Squares - PLS), para a análise desses caminhos (SmartPLS Community, 2005).

A seguir serão descritas as análises univariada e multivariada, respectivamente.

\section{Análise univariada}

A análise univariada dos dados coletados se refere a como os dados são distribuídos, levando em conta apenas uma variável ou característica (SCHARADER, 1978). Em um primeiro momento, deve-se realizar uma análise crítica dos dados, em termos de inconsistência de respostas intrarrespondentes e levantamento de missing data (ausência de dados). A partir disso, pode-se 
calcular as estatísticas descritivas relacionadas com a distribuição de frequências: medidas de tendência central (médias), medidas de dispersão (variância, desviopadrão e coeficiente de variabilidade) e medidas de forma (assimetria e curtose). Nessa fase da análise, a normalidade dos dados também foi estatisticamente testada por meio do teste de Kolmogorov-Smirnov (COOPER e SCHINDLER, 2003; HAIR et al., 2006).

A média é calculada somando-se todas as pontuações dadas pelos respondentes e dividindo o resultado obtido pelo número de respondentes. $O$ cálculo do desvio padrão é feito com base nos seguintes passos:

1) calcula-se o desvio, que é a subtração do valor dado por cada respondente menos a média;

2) computa-se a variância, que é a soma do quadrado dos desvios dividida pelo número de ocorrências ;

3) calcula-se o desvio padrão que é a raiz quadrada da variância.

O coeficiente de variabilidade é calculado dividindo-se o desvio padrão pela média (VUOLO, 1996).

A normalidade das variáveis pode ser analisada mediante os testes de Kolmogorov-Smirnov e Shapiro Wilk (HAIR et al. 2006). Nesses testes, se uma variável possui distribuição normal, a significância ${ }^{23}$ deve estar acima de 0,05.

As medidas de assimetria (skewness) e curtose (kurtosis) também são utilizadas para analisar a normalidade das variáveis. Segundo Hair (2006), esses valores devem ser próximos de zero para indicar normalidade.

A assimetria é a propriedade que mede a tendência de maior concentração em relação a um ponto central. Quanto maior a distância, tanto positiva quanto negativa em relação ao ponto central, maior é a assimetria da distribuição.

A curtose é a característica que se refere ao grau de achatamento da curva formada pela distribuição do resultado de uma variável. Quanto mais

\footnotetext{
${ }^{23}$ A significância estatística ou nível $p$ de um resultado é uma medida estimada do grau em que esse resultado é "verdadeiro". Mais tecnicamente, o valor do nível-p representa um índice decrescente da confiabilidade de um resultado. Quanto mais alto o nível-p, menos se pode acreditar que a relação observada entre as variáveis na amostra é um indicador confiável da relação entre as respectivas variáveis na população. Especificamente, o nível-p representa a probabilidade de erro envolvida em aceitar o resultado observado como válido (HAIR et al. 2006).
} 
achatada ou mais pontiaguda for essa curva, maior será a distância que essa variável está da normalidade.

As estatísticas univariadas caracterizam os respondentes em termos de seus perfis sociodemográficos, além de elaborar um perfil da amostra baseado em suas opiniões.

\section{Análise multivariada}

A técnica de análise multivariada serve para examinar simultaneamente duas ou mais variáveis. Segundo Malhotra (2006, p.441), "elas diferem das técnicas univariadas pelo fato de mudarem o foco do nível (média) e da distribuição (variância) dos fenômenos para o grau de relacionamento (correlações ou covariâncias) entre eles.". Essas técnicas foram utilizadas para avaliar as escalas e o modelo conceitual proposto, tendo em vista que o último é um conjunto de relações de dependência entre constructos que podem ser testados empiricamente, ou seja, a teoria posta em prática (HAIR et al., 2006).

Nessa etapa, as técnicas utilizadas foram: (1) a análise da confiabilidade da escala pelo coeficiente Alfa de Cronbach e (2) teste do modelo conceitual por meio de Modelagem de Equações Estruturais (Structural Equations Modeling SEM).

(1) A análise de confiabilidade de escala pelo coeficiente de Alfa de Cronbach

A confiabilidade de escala é obtida a partir da teoria clássica de medição, que considera que o valor observado $\operatorname{Var}(X)$ é composto por duas variáveis: o valor verdadeiro $\operatorname{Var}(T)$ e o erro de medição $\operatorname{Var}(E)$. Segundo Hayes (1995), a variância de cada conjunto de variáveis é dada pela equação (4.1):

$$
\operatorname{Var}(X)=\operatorname{Var}(T)+\operatorname{Var}(E)
$$

Assim à medida que a variância associada aos erros aleatórios diminui, a variância dos valores observados se aproxima da variância dos valores verdadeiros, o que representa maior confiabilidade das medições. 
Entretanto, como em muitos problemas reais os valores verdadeiros das variáveis não são conhecidos, é impossível determinar a confiabilidade diretamente por meio de cálculo de correlação entre os valores observados e verdadeiros. Segundo Trochim (2006), existem quatro procedimentos para estimar a confiabilidade das medições:

(a) confiabilidade entre avaliadores, que busca obter o grau com que diferentes avaliadores fornecem estimativas consistentes sobre 0 mesmo fenômeno;

(b) confiabilidade de teste / reteste, que busca estimar a consistência de uma medida em momentos diferentes;

(c) confiabilidade paralela, utilizada para determinar a consistência dos resultados de duas pesquisas distintas construídas com o mesmo objetivo;

(d) confiabilidade de consistência interna, utilizada para determinar a consistência dos resultados da avaliação de itens de uma pesquisa. A estimativa da confiabilidade de consistência interna de questionários é comumente medida por meio do coeficiente Alfa de Cronbach.

Apresentado por Lee J. Cronbach em 1951, o coeficiente Alfa de Cronbach (assim como é cientificamente conhecido) é uma das estimativas da confiabilidade de um questionário aplicado em uma pesquisa. Dado que todos os itens da escala utilizam a mesma escala de medição, o coeficiente alfa, com valores entre (0 e 1), é calculado a partir da variância dos itens individuais e das covariâncias entre os itens por meio da equação (4.2):

$$
\alpha=\left(\frac{k}{k-1}\right)\left(1-\frac{\sum_{i=1}^{k} S_{i}^{2}}{S_{t}^{2}}\right)
$$


Onde:

k é o número de itens do questionário;

$S_{i}^{2}$ é a variância do item $i$;

$S_{t}^{2}$ é a variância total do questionário.

É relevante ressaltar que, apesar da literatura científica apresentar as aplicações do coeficiente alfa nas diversas áreas do conhecimento de forma ampla e abrangente, ainda não existe um consenso entre os pesquisadores acerca da interpretação da confiabilidade da escala obtida a partir do valor deste coeficiente.

A confiabilidade das escalas foi avaliada por meio do coeficiente Alfa de Cronbach, que representa a correlação entre os itens que constituem cada constructo (CHURCHILL, 1983). Pelas recomendações de Hair et al. (2006), o Alfa de Cronbach é aceitável para valores maiores que 0,60. Freitas e Rodrigues (2005) apresentam uma sugestão de classificação da confiabilidade a partir do cálculo do coeficiente Alfa de Cronbach, demonstrada na a TAB.4.16.

TABELA 4.16 - Classificação da confiabilidade a partir do coeficiente Alfa de Cronbach

\begin{tabular}{lccccc}
\hline Confiabilidade & Muito Baixa & Baixa & Moderada & Alta & Muito Alta \\
\hline Valor de $\alpha$ & $\alpha<=0,3$ & $0,3<\alpha<=0,6$ & $0,6<\alpha<=0,75$ & $0,75<\alpha<=0,9$ & $\alpha>0,9$ \\
\hline Fonte: (FREITAS e RODRIGUES, 2005)
\end{tabular}

Além desse coeficiente, as correlações item-total foram examinadas. Essa correlação é tida como evidência de que a escala tem forte relação com o constructo que se busca mensurar. Ela representa também uma medida de consistência interna, ou seja, há uma relação consistente entre o constructo e todas as suas variáveis (HAIR et al., 2006). Segundo Streiner (1995), esta correlação deveria ser moderadamente alta, e qualquer item cuja correlação itemtotal corrigido fosse menor que 0,20 deveriam ser eliminados da contagem. 
(2) A Modelagem de Equações Estruturais (Structural Equations Modeling $\underline{\text { SEM) }}$

A Modelagem de Equações Estruturais é uma técnica estatística utilizada para estimar e testar relações causais entre variáveis com base em dados estatísticos e hipóteses causais qualitativas. Ela pode ser considerada como a segunda geração das análises multivariadas, pois permite ao pesquisador considerar simultaneamente relações entre múltiplos constructos independentes e dependentes (URBACH e AHLEMANN, 2010).

Primeiramente, o pesquisador deve analisar a teoria à luz dos objetivos da pesquisa para, então, definir quais variáveis independentes podem predizer cada variável dependente. A partir disso, o modelo estrutural expressa as relações entre as variáveis dependentes e independentes, podendo ainda incluir casos em que uma variável dependente torna-se a variável independente em outra relação (HAIR et al., 2006). A SEM permite incorporar constructos latentes à análise, fornecendo um modelo de mensuração que específica as correspondências entre eles e seus indicadores mensuráveis. Também avalia a contribuição de cada item na representação do constructo associado, medindo sua conformidade e incorporando essas informações à estimativa das relações entre os constructos (HAIR et al., 2006).

A SEM considera os erros de mensuração para as variáveis observadas e testa estatisticamente as hipóteses teóricas ou de mensuração, com base nos dados empíricos, ou seja, permite realizar uma análise confirmando a proposição teórica (CHIN, 1998).

A técnica de modelagem de equações estruturais, até hoje mais difundida e utilizada, baseia-se em covariância e se denomina Covariance-Based Structural Equations Modeling - CB-SEM. Nessa abordagem, utiliza-se uma série de medidas para checar se a teoria levantada pelo pesquisador consegue explicar a matriz de covariância observada ou aquela resultante dos dados medidos em campo, ou seja, se o modelo proposto estima com precisão todas as relações entre os constructos e se o modelo de mensuração os define adequadamente. $O$ resultado é uma matriz de covariância estimada próxima da matriz de covariância observada (HAIR et al., 2006). 
Os pacotes de software estatístico mais comumente utilizados para essa técnica (CB-SEM) são LISREL, EQS ou AMOS (Analysis of Moment Structures) (HAIR et al. 2011).

Uma técnica alternativa para a modelagem de equações estruturais é o modelo PLS-SEM (Partial Least Squares - Structural Equations Modeling). Tratase de uma forma de modelagem causal que busca maximizar a variância explicada dos constructos latentes dependentes, ao contrário do CB-SEM, cujo objetivo é reproduzir a matriz de covariância teórica sem se preocupar com a variância explicada. A aplicação técnica do PLS tem recebido crescente aceitação dos pesquisadores nas áreas de Marketing, Administração de Sistemas de Informação, Comportamento Organizacional, entre outras (HENSELER et al., 2009; URBACH e AHLEMANN, 2010; HAIR et al., 2011).

Segundo Henseler et al. (2009), um dos principais motivos do crescimento da adoção do PLS-SEM é que ele é adequado nos estágios iniciais do desenvolvimento de teorias, quando se precisa validar modelos empíricos. A técnica PLS tem como principal objetivo uma análise causal preditiva em situações de alta complexidade em que haja poucas informações teóricas disponíveis (URBACH e AHLEMANN, 2010).

Quando as premissas da CB-SEM são violadas e resultam em problemas metodológicos, tais como a incapacidade de convergir para uma solução, valores fora de limites razoáveis e erros-padrão demasiado altos para as estimativas dos parâmetros, a PLS-SEM representa uma alternativa metodológica adequada para testar teorias (HENSELER et al.,2009). A técnica PLS pode ser aplicada a amostras pequenas, permite estimar modelos bastante complexos (com grande número de variáveis) e possui premissas menos restritivas com relação à distribuição das variáveis e de seus erros ou resíduos (HENSELER et al., 2009; URBACH e AHLEMANN, 2010).

O modelo conceitual proposto no presente estudo foi testado por meio do software SPSS AMOS para verificar a adequação da modelagem de equações estruturais pelo método baseado na covariância (CB-SEM). Os resultados indicaram inadequação desse método, pois além de todos os resultados não apresentassem uma distribuição normal, o número de casos na amostra mostrouse inadequado para estimar os parametros livres do modelo estrutural, ou seja, o número de indicadores (35) é grande em relação a número da amostra, que é 
pequena (171), resultando na incapacidade do modelo de convergir para a solução. Além de sua relativa complexidade, o modelo proposto é também do tipo focado, ou seja, é caracterizado por possuir um pequeno número de variáveis latentes endógenas explicadas por um número alto de variáveis exógenas ${ }^{24}$.

Considera-se um modelo focado quando o número de variáveis exógenas é pelo menos o dobro do número de endógenas (HAIR et al., 2012). Esse tipo de modelo adequa-se melhor aos objetivos de previsão da PLS-SEM, principalmente quando se visa identificar os principais constructos que exercem influência no modelo (HAIR et al., 2011). No caso do presente estudo, um dos objetivos da pesquisa quantitativa era justamente verificar a importância de cada dimensão na responsabilidade social.

Em vista dessas considerações, para analisar estatisticamente o modelo teórico proposto, foi selecionada a modelagem de equações estruturais utilizando o método PLS com a ajuda do software SmartPLS. Como pode ser constatado no capítulo referente à análise dos resultados de campo, a PLS-SEM mostrou-se a via mais adequada de análises para as características dos dados, tamanho da amostra e especificidades do modelo.

A regra indicada na literatura sobre o PLS-SEM para definir o tamanho mínimo da amostra é que seja dez vezes maior que o número de caminhos estruturais direcionados a um determinado constructo latente no modelo estrutural (HAIR et al., 2011). Para o presente estudo, que tem 7 caminhos, o número mínimo exigido é de 70 casos. Esse número foi ultrapassado pela amostra coletada (171), o que possibilitou o uso da técnica de bootstrapping ${ }^{25}$. Embora essa técnica não leve em conta o tamanho dos efeitos, a confiabilidade, o número de indicadores, e outros fatores que sabidamente afetam o poder das estimativas, ela fornece uma avaliação aproximada do numero mínimo de casos exigidos (HAIR et al., 2012).

Outro motivo importante para o uso do PLS-SEM em vez de modelagem baseada em covariância é sua melhor adequação a modelos com variáveis latentes exclusivamente formativas ou uma combinação de variáveis formativas e reflexivas (HAIR et al., 2011). Os indicadores reflexivos são considerados "efeitos"

\footnotetext{
${ }^{24}$ Variáveis latentes endógenas são as variáveis dependentes e variáveis latentes exógenas são as variáveis independentes (HAIR, RINGLE e SARSTEDT, 2011).

${ }^{25}$ bootstrapping é um teste estatístico que envolve o uso de várias sub-amostras aleatórias retiradas da amostra original, com substituição (HAIR et al., 2011).
} 
das variáveis latentes, em outras palavras, eles "causam" os indicadores (CHIN, 1998).

Indicadores reflexivos têm sido normalmente usados em estudos utilizando a modelagem de equações estruturais (URBACH e AHLEMANN, 2010). Cada indicador reflexivo representa uma medida da variável latente, afetada por um erro (HENSELER et al., 2009). Em situações como os estágios iniciais do desenvolvimento de modelos, é adequado usar modelo de mensuração formativo quando o constructo é definido como a combinação de indicadores que representam dimensões independentes e isoladas (DIAMANTOPOULOS e SIGUAW, 2006). Na modelagem de equações estruturais por covariância (CBSEM), os analistas normalmente encontram problemas de identificação ao usar medidas formativas, ao passo que na modelagem do tipo PLS-SEM, problemas semelhantes não ocorrem (HENSELER et al., 2009).

No modelo conceitual proposto, o constructo responsabilidade social é tratado como uma variável latente formada pelas dimensões ética, público interno, meio ambiente, fornecedor, cliente, comunidade e governo/sociedade. Essas dimensões, por sua vez, são definidas por constructos reflexivos. Portanto tratase de um modelo reflexivo-formativo, justificando, assim, o uso da técnica PLSSEM.

A PLS-SEM baseia-se em dois procedimentos iterativos usando estimativas de mínimos quadrados, cujos algoritmos objetivam minimizar a variância de todas as variáveis dependentes com base nas estimativas dos parâmetros (CHIN, 1998). Em vez de assumir pesos iguais para todos os indicadores da escala, os algoritmos permitem que cada indicador varie de acordo com o peso de sua contribuição para a variável latente (HAIR et al., 2011).

Em toda técnica de modelagem de equações estruturais, seja por CB-SEM ou PLS-SEM, dois modelos são avaliados: o modelo de mensuração, que mostra como as variáveis mensuráveis se combinam para representar os constructos e o modelo estrutural, que mostra como os constructos estão associados entre si. A vantagem da abordagem de equações estruturais, em comparação com outras técnicas multivariadas, é que com ela se examina uma série de relações de dependência simultaneamente, utilizando uma única abordagem estatística para testar o escopo total das relações projetadas (GARVER e MENTZER, 1999; HAIR et al., 2006; GEFEN et al., 2011). 
Assim, os pesquisadores podem avaliar variáveis latentes nos seguintes níveis: (a) outer model ou modelo de mensuração que visa testar as relações entre variáveis latentes no nível de observação. (b) inner model ou modelo estrutural ${ }^{26}$, compreende as relações entre as variáveis latentes independentes (ou exógenas) e dependentes (ou endógenas), que devem derivar das considerações teóricas (HAIR et al., 2012).

Para cada uma das variáveis latentes do modelo de equações estruturais (inner model), um outer model (mensuração) tem que ser definido para representar a relação entre os indicadores empiricamente observáveis e as variáveis latentes (URBACH e AHLEMANN, 2010).

(a) Outer Model (Modelo de Mensuração)

A avaliação do outer model considera a confiablilidade de cada indicador individual e das medidas compostas de cada constructo, bem como a validade convergente e discriminante das suas medidas. Essa avaliação verifica se os constructos estão bem representados por suas variáveis indicadoras (HAIR et al., 2012).

Os pesquisadores devem distinguir entre perspectivas de mensuração reflexivas ou formativas. Segundo Hair et al. (2012), os modelos reflexivos devem ser avaliados com relação à:

confiabilidade, onde são analisadas:

- confiabilidade da consistência interna por meio da;

- cargas fatoriais padronizadas ou outer loadings.

validade, onde são analisadas:

- validade convergente por meio da análise da média da variância extraída (Average Variance Extracted - AVE);

\footnotetext{
${ }^{26} \mathrm{Na}$ literatura, 'quando se refere à CB-SEM usa-se os termos "modelo estrutural" e "modelo de mensuração". Ao se referir à PLS-SEM, usa-se geralmente os termos "inner model" e "outer model", respectivamente (HAIR et al., 2012).
} 
○ validade discriminante pelo critério de Fornell-Lacker e cargas cruzadas (cross-loadings);

- comparação da raiz quadrada da AVE com as correlações entre pares de constructos.

A confiabilidade representa o quanto uma variável ou conjunto delas é consistente no que se destina a medir, ou seja, o constructo latente. Variáveis confiáveis são aquelas que, após várias medições, serão sempre consistentes em seus valores. A confiabilidade baseia-se no grau de interrelação dos indicadores e difere da validade porque não se relaciona com o que deveria ser mensurado, mas com a forma como isso é mensurado (HAIR et al., 2006).

$\mathrm{Na}$ modelagem de equações estruturais pelo método PLS, a análise da confiabilidade dos constructos baseia-se na confiabilidade composta, que é entendida como uma estimativa da consistência interna do constructo. $O$ valor da confiabilidade da consistência interna deve estar acima de 0,70 nos estágios iniciais da pesquisa. Valores acima de 0,80 ou 0,90 em estágios mais avançados são considerados satisfatórios, enquanto que um índice abaixo de 0,60 indica falta de confiabilidade (HENSELER et al., 2009). Um baixo índice de consistência interna pode resultar de uma variedade de causas, por exemplo, uma definição falha do constructo (HULLAND, 1999).

Além da confiabilidade dos constructos, a confiabilidade de cada indicador precisa ser considerada. A confiabilidade dos indicadores descreve em que grau uma variável é consistente naquilo que ela intenciona medir. As cargas fatoriais padronizadas dos indicadores reflexivos podem ser usadas para avaliar a confiabilidade. Em geral, uma variável latente deve explicar pelo menos $50 \%$ da variância de cada indicador. Isso significa que as cargas absolutas padronizadas dos indicadores devem ser de no mínimo 0,707 , que é o equivalente à $\sqrt{0,5}$ (URBACH e AHLEMANN, 2010). Os indicadores com cargas entre 0,40 e 0,70 devem ser removidos da escala se isso levar a um aumento da confiabilidade composta acima dos limites recomendados e se a validade não for afetada (HAIR et al., 2011; URBACH e AHLEMANN, 2010).

A equação 4.3 descreve o cálculo da confiabilidade composta: 


\section{$\left(\Sigma \lambda_{i}\right)^{2}$ \\ $\left(\Sigma \lambda_{j}\right)^{2}+\Sigma E_{j}$}

Onde:

$$
\begin{array}{ll}
\lambda \mathrm{j} & =\text { carga fatorial padronizada do indicador } \\
\mathrm{j} & =\text { indicador } \\
E_{j} & =\text { erro do indicador }
\end{array}
$$

$\mathrm{Na}$ prática, é comum encontrar itens de mensuração em um modelo estimado com cargas abaixo do limite de 0,70 , especialmente quando os novos itens ou escalas estão sendo empregados. Uma carga baixa pode ser resultado de: (1) um item mal formulado; (2) um item inadequado ou (3) a transferência inadequada de um item de um contexto para outro. Mesmo que o pesquisador tenha uma forte justificativa teórica para incluir itens com baixas cargas, isso deve ser cuidadosamente verificado para evitar vieses nas estimativas dos parâmetros que interrelacionam os constructos. Em geral, recomenda-se que itens com cargas abaixo de 0,40 ou 0,50 sejam eliminados (HULLAND, 1999). Por outro lado, cargas acima de 0,95 devem ser encaradas com ressalvas, pois podem indicar um problema de viés no método de pesquisa (URBACH e AHLEMANN, 2010).

A avaliação da validade dos modelos de mensuração reflexivos enfoca a validade convergente e discriminante. Validade convergente significa que um conjunto de indicadores representa um único e exclusivo constructo, algo que pode ser demonstrado pela sua unidimensionalidade (HENSELER et al., 2009).

Segundo Hair et al. (2006), unidimensionalidade significa que um grupo de indicadores ou variáveis mensuradas refere-se a apenas um constructo. A validade convergente é importante quando o modelo possui mais de um constructo, pois a hipótese é de que cada indicador se relacione a apenas um constructo. Nos modelos de mensuração reflexivos, deve-se examinar a variância média extraída (Average Variance Extracted - $\underline{\mathrm{AVE}}$ ), cujo valor deve ser de no mínimo 0,50, indicando que a variável latente atende mais da metade da variância do seu indicador. 
A validade discriminante verifica se uma determinada medida não está relacionada indevidamente com indicadores de construto distintos. Da mesma forma, constructos distintos devem exibir uma diferença significativa entre eles (HENSELER et al.,2009). A validade discriminante alta evidencia que o constructo é único e consegue capturar algum fenômeno que as outras medidas não conseguem (HAIR et al., 2006). A validade discriminante também significa que os itens individuais mensurados representam apenas um constructo latente. Os itens de uma escala não devem ter convergência com itens de uma escala diferente, portanto a presença de cargas cruzadas $^{27}$ indica um problema com esse tipo de validade (HAIR et al., 2006). Por outro lado, correlações baixas entre variáveis ou constructos indicam a existência de validade discriminante (GARVER e MENTZER, 1999).

Para avaliar a validade discriminante, dois critérios são recomendados: o primeiro é o critério Fornell-Lacker, onde um constructo latente compartilha mais variância com seus indicadores do que com qualquer outra variável latente do modelo estrutural. Em termos estatísticos, a AVE de cada constructo latente deve ser maior do que a maior correlação ao quadrado desse constructo, quando comparado com qualquer outro constructo latente. $O$ segundo critério refere-se às cargas cruzadas, ou seja, a carga do indicador relativa ao constructo latente com o qual está associado deve ser mais alta do que a carga que ele apresenta para os constructos restantes no modelo (HAIR et al., 2011).

(b) Inner Model (Modelo Estrutural)

A segunda etapa do emprego da técnica de Modelagem de Equações Estruturais compreende o teste da validade do modelo estrutural e das correspondentes relações teóricas hipotéticas. Os parâmetros estimados para as relações estruturais fornecem evidências empíricas diretas acerca das relações levantadas pelas hipóteses (quais constructos estão relacionados entre si e qual a natureza de cada relação) representadas no modelo estrutural (HAIR et al., 2011).

Quando se utiliza uma técnica CB-SEM baseada em covariância, o que se busca é estimar parâmetros que reproduzem, o mais próximo possível, a matriz

\footnotetext{
${ }^{27}$ As cargas cruzadas são obtidas por meio da correlação dos scores dos componentes de cada
} variável latente com todos os scores dos outros itens (GEFEN e STRAUB, 2005) 
de covariância observada. A PLS-SEM, ao contrário, tem o principal objetivo de minimizar os erros ou maximizar a variância explicada para todos os constructos endógenos. Uma consequência desses diferentes objetivos é que não existe uma medida geral para a adequação do ajuste (goodness-of-fit) dos modelos estimados por PLS (HAIR et al., 2011). Nos modelos PLS, o objetivo de maximizar a variância explicada só pode ser verificado pelo exame dos valores do coeficiente de determinação $\boldsymbol{R}^{2}$ dos constructos dependentes ou endógenos (HULLAND, 1999), que mede a relação entre a variância explicada e a variância total de uma variável latente (URBACH e AHLEMANN, 2010).

Segundo Urbach e Ahlemann (2010), o coeficiente de determinação, também chamado de $R^{2}$, é uma medida de ajustamento de um modelo estatístico. $O R^{2}$ varia entre 0 e 1 , indicando, em percentagem, o quanto o modelo consegue explicar os valores observados. Quanto maior o $R^{2}$, mais explicativo é modelo e melhor ele se ajusta à amostra. Por exemplo, se o $R^{2}$ de um modelo é 0,877797 , isso significa que $87,77 \%$ da variável dependente consegue ser explicada pelos regressores presentes no modelo. As equações de (4.4) até (4.8) descrevem como é realizado o cálculo do $R^{2}$.

$$
S Q_{\text {tot }}=\sum_{i=1}^{n}\left(y_{i}-\bar{y}\right)^{2}
$$

Onde:

$S Q_{t o t}$ é a soma total dos quadrados;

$n$ é o número de observações;

$y_{i}$ é o valor observado;

$\bar{y}$ é a média das observações.

Essa equação fornece a Soma Total dos Quadrados, ou seja, a soma dos quadrados das diferenças entre a média e cada valor observado (variância total).

$\mathrm{Na}$ equação (4.5), a Soma dos Quadrados Explicada indica a diferença entre a média das observações e o valor estimado para cada observação, e soma 
os respectivos quadrados. Quanto menor for a diferença, maior poder explicativo detém o modelo (variância explicada).

$$
S Q_{\exp }=\sum_{i=1}^{n}\left(\hat{y}_{i}-\bar{y}\right)^{2}
$$

Onde:

$S Q_{\text {exp }}$ é a soma total dos quadrados;

$\hat{y}_{i}$ é o valor estimado (previsão) de $y_{i}$

A equação (4.6) é a Soma dos Quadrados dos Resíduos (SQ $S$ res), que calcula a parte que não é explicada pelo modelo.

$$
S Q_{\mathrm{res}}=\sum_{i=1}^{n}\left(\hat{y}_{i}-y_{i}\right)^{2}
$$

Portanto, a Soma dos Quadrados Total $\left(S Q_{\text {tot }}\right)$ é dada pela equação (4.7) :

$$
S Q_{\text {tot }}=S Q_{\exp }+S Q_{\text {res }}
$$

A equação acima normalizada resulta na equação (4.8):

$$
R^{2}=\frac{S Q_{\exp }}{S Q_{\text {tot }}}=1-\frac{S Q_{\mathrm{res}}}{S Q_{\mathrm{tot}}}
$$

O coeficiente $R^{2}$ deve apresentar níveis altos para explicar adequadamente a variância da variável latente endógena. Segundo Hair et al. (2011), para estudos na área de Marketing, os valores de $R^{2} \quad 0,75,0,5$ e 0,25 podem ser descritos como substanciais, moderados ou fracos, respectivamente. 
O valor de $R^{2}$ deve ser suficiente para que o modelo tenha um nível mínimo de poder explicativo (URBACH e AHLEMANN, 2010). Assim, quanto mais alto o valor de $R^{2}$, melhor o ajuste do modelo (ROY, 2008).

Segundo Henseler et. al (2009), quando uma variável latente endógena é explicada por apenas algumas variáveis latentes exógenas (uma ou duas), um $R^{2}$ moderado pode ser aceitável. Porém, com a existência de diversas variáveis latentes exógenas estatisticamente significativas, o $R^{2}$ deve ter um nível pelo menos substancial. Níveis baixos de $R^{2}$ indicam fraca base teórica e um modelo incapaz de explicar as variáveis latentes endógenas.

Um passo importante para a avaliação do modelo estrutural é a análise dos coeficientes dos caminhos (path coefficients) entre as variáveis latentes do modelo. Esses coeficientes podem ser interpretados como coeficientes beta padronizados de regressões ordinárias de mínimos quadrados. Deve-se verificar o sinal, a magnitude e a significância dos coeficientes dos caminhos (HAIR et al., 2011).

O coeficiente beta é calculado a partir dos valores das variáveis (tanto a dependente como as independentes) padronizados. Padronizar os valores de uma variável significa subtrair de cada valor original a sua média e dividir o resultado pelo seu desvio padrão. Os valores desses coeficientes servem para verificar quais são as variáveis que têm maior "força" explicativa, independentemente de suas distintas escalas ou unidades de medida utilizadas (HAIR et al., 2011).

Os caminhos devem ter sinais algébricos positivos ou negativos, compatíveis com as hipóteses assumidas; sinais opostos ao da relação teórica presumida não suportam hipóteses pré-formuladas (URBACH e AHLEMANN, 2010).

A magnitude dos coeficientes indica a força da relação entre duas variáveis latentes que, segundo Urbach e Ahlemann (2010), deve ser maior que 0,10 para causar algum impacto no modelo.

Em um teste clássico de hipóteses são definidas duas hipóteses: a nula $\left(H_{0}\right)$ e a alternativa $\left(H_{\mathrm{A}}\right)$. Em muitas aplicações da estatística, convenciona-se definir a hipótese alternativa como a hipótese formulada pelo pesquisador e, em 
princípio, a hipótese nula é considerada a verdadeira. Ao se confrontar a hipótese nula com os achados de uma amostra aleatória tomada de uma população de interesse, se verifica se em termos probabilísticos ela é aceitável, o que leva a rejeitar ou não $H_{0}$. Se $H_{0}$ não é rejeitada, é considerada verdadeira; caso contrário, $H_{\mathrm{A}}$ é considerada verdadeira (PAGANO e GAUVREAU, 2004).

Pelo fato de que essa tomada de decisão se baseia em uma amostra e não na população inteira, podem ocorrer dois tipos de erros. O erro tipo I, quando se rejeita $H_{0}$ e ela é verdadeira; e o erro tipo II, quando não se rejeita $H_{0}$ e ela é falsa. Na TAB.4.17 são apresentadas as possibilidades que podem surgir durante a pesquisa.

TABELA 4.17 - Teste de hipótese

\begin{tabular}{lcc} 
& $\begin{array}{c}\text { A hipótese } \boldsymbol{H O} \\
\text { é verdadeira }\end{array}$ & $\begin{array}{c}\text { A hipótese } \boldsymbol{H O} \\
\text { é falsa }\end{array}$ \\
\hline Rejeita-se $H 0$ & Erro do tipo I & Sem erro \\
\hline Não se rejeita HO & Sem erro & Erro do tipo II \\
\hline
\end{tabular}

A probabilidade de se cometer um erro tipo I é chamada de nível de significância, denotado pela letra grega $\alpha$. O nível de significância é geralmente determinado pelo pesquisador antes da coleta dos dados. Em muitas aplicações da estatística, o nível de significância é tradicionalmente fixado em 0,05 (PAGANO e GAUVREAU, 2004).

Uma das funções da análise estatística é estabelecer se os resultados obtidos têm significância estatística de acordo com limites pré-estabelecidos. Quando se formula uma hipótese em relação a uma determinada característica de uma população, a amostra dela retirada pode:

- pertencer à população de origem, portanto as diferenças observadas são decorrentes de flutuações biológicas normais ou

- não pertencer a essa população, e as diferenças encontradas representam um efeito real, não podendo ser atribuídas ao acaso.

No primeiro caso, diz-se que os valores encontrados "não são estatisticamente significativos" e no segundo, "são estatisticamente significativos". 
É importante notar que essas expressões sempre são empregadas tendo em vista "níveis de significância" previamente escolhidos. A significância de um resultado também é denominada de valor $\boldsymbol{p}$ ( $\boldsymbol{p}$-value).

O valor- $\boldsymbol{p}$ ou $\boldsymbol{p}$-value pode ser definido como a menor escolha que se faz para o nível de significância, de forma a se rejeitar a $H_{0}$. Rejeita-se $H_{0}$ se o valor-p é menor que $\alpha$, caso contrário, não se rejeita $H_{0}$. O valor-p e nível de significância não são sinônimos. O valor- $p$ é sempre obtido de uma amostra, enquanto o nível de significância é geralmente fixado antes da coleta dos dados (URBACH e AHLEMANN, 2010).

Para determinar a significância dos caminhos estruturais, técnicas de reamostragem como o bootstrapping ou jackknifing, devem ser utilizadas (URBACH e AHLEMANN, 2010).

O procedimento de bootstrapping é um teste não paramétrico ${ }^{28}$, já que a PLS presume que os dados não tenham distribuição normal. Ele envolve o uso de várias sub-amostras aleatórias retiradas da amostra original, com substituição, ou seja, sempre retornando a sub-amostra para a amostra original (HAIR et al., 2011). O procedimento estima os coeficientes dos caminhos para cada amostra do bootstrapping que formam uma distribuição que pode ser vista genericamente como a da amostra. O processo também fornece a média e os erros-padrão para cada coeficiente dos caminhos do modelo e permite testar sua significância, indicando o valor do teste $t$ de Student (HENSELER et al., 2009; HAIR et al., 2011).

O teste $\boldsymbol{t}$ de Student ou somente teste $\boldsymbol{t}$ é um teste de hipótese que usa conceitos estatísticos para rejeitar ou não uma hipótese (BOX, 1987).

O teste $t$ para média de uma amostra consiste em medir a probabilidade da média da amostra ( $\left.\mu_{0}\right)$ em questão apresentar o valor observado $\bar{x}$.

\footnotetext{
${ }^{28}$ Os testes paramétricos baseiam-se em medidas intervalares da variável dependente (um parâmetro ou característica quantitativa de uma população). A utilização desses tipos de testes exige que sejam satisfeitos os seguintes requisitos: distribuição normal, variância homogênea e medidas com intervalos contínuos e iguais. Os testes não paramétricos, quando comparados com os testes paramétricos, requerem menos pressupostos para as distribuições. São muito úteis para a análise de testes de hipóteses; para a análise de amostras grandes em que os pressupostos paramétricos não se verifiquem, para as amostras muito pequenas e para as investigações que envolvam hipóteses cujos processos de medida sejam ordinais (TUCKMAN, 2000).
} 
Para isso, estipula-se, por exemplo, que a hipótese nula é $\bar{x} \leq \mu_{0}$ e que, por consequência, a hipótese alternativa é $\bar{x}>\mu_{0}$. Utiliza-se a equação (4.9) para o cálculo da estatística $t$ (valor de $t$ ).

$$
t=\frac{\bar{x}-\mu_{0}}{\frac{s}{\sqrt{n}}}
$$

Onde:

$\bar{x}$ : média da amostra;

$\mu_{0}$ : valor fixo usado para comparação com a média da amostra;

$s$ : desvio padrão amostral;

$n$ : tamanho da amostra.

$\mathrm{Na}$ equação acima, quanto maior $\bar{x}-\mu_{0}$, maior será $t$. Ou seja, quanto maior a distância dos valores observados ao valor comparado, mais certeza se terá em afirmar que eles são diferentes. Do mesmo modo, $t$ aumenta quando o tamanho da amostra $n$ é maior ou quando o desvio padrão $s$ é menor. Quanto maior $t$, mais confiança se tem ao rejeitar a hipótese nula, ou seja, mais certeza se tem em afirmar que $\bar{x} \leq \mu_{0}$ não é verdadeiro (BOX,1987).

Além do teste de significância de cada coeficiente dos caminhos, deve-se testar o tamanho do efeito de cada um deles (effect size) no modelo de equações estruturais. Isso pode ser realizado por meio do cálculo do $\boldsymbol{f}^{2}$ de Cohen, que mede o aumento no $R^{2}$ da variável latente à qual o caminho se conecta em relação à proporção de variância da variável latente endógena que permanece não explicada (HENSELER et al., 2009; URBACH e AHLEMANN, 2010). Em outras palavras, o teste de Cohen permite avaliar a explicação incremental da variável independente sobre a variável dependente (RINGLE et al., 2012).

$O R^{2}$ de cada variável latente dependente é o ponto de partida para se analisar o modelo estrutural, já que a interpretação da análise PLS-SEM é semelhante à regressão dos mínimos quadrados. Adicionalmente, mudanças nesse índice podem ser exploradas para verificar se o impacto de determinada 
variável latente independente sobre a variável dependente é substancial (CHIN, 1998, apud URBACH e AHLEMANN, 2010).

O teste do effect size - $f^{2}$ de Cohen mede o impacto relativo de uma dada variável latente exógena sobre a variável latente endógena, por meio das mudanças no valor de $R^{2}$ (HAIR et al., 2012), permitindo, dessa forma, estimar o tamanho do efeito de cada caminho do modelo de equações estruturais (RINGLE et al., 2012). $O f^{2}$ representa a força da relação teórica encontrada em uma análise e fornece uma estimativa do grau em que o fenômeno existe na população (CHIN et al., 2003). Valores de $f^{2}$ entre 0,02 e 0,15 , entre 0,15 e 0,35, e acima de 0,35 indicam que uma variável latente exógena tem um efeito respectivamente pequeno, médio ou grande sobre uma variável latente endógena, respectivamente (URBACH e AHLEMANN, 2010).

Segundo recomendações de Chin (1998, apud PUSCHEL, MAZZON e HERNANDEZ, 2010) e de Chin, Marcolin e Newsted (2003), o $f^{2}$ pode ser calculado conforme a equação (4.10):

$$
f^{2}=\frac{R^{2} \text { Total }-R^{2} \text { Main Effects }}{1-R^{2} \text { Total }}
$$

Onde $R^{2}$ Total é o $R^{2}$ total do modelo (quando a variável independente é incluída na equação estrutural) e o $R^{2}$ Main Effects é o $R^{2}$ da variável latente dependente quando a variável independente é omitida da equação estrutural.

O modelo estrutural também deve ser avaliado em termos de sua relevância preditiva, ou seja, ele deve ser capaz de predizer adequadamente cada indicador do constructo latente endógeno (HAIR et al., 2011). Isso se faz por meio do procedimento blindfolding, um teste não paramétrico que gera estimativas das variâncias residuais. Esse teste omite um determinado número de casos da amostra, sendo que a verificação de quanto essa previsão está correta é feita pela estatística $\boldsymbol{Q}^{2}$ de Stone-Geisser (URBACH e AHLEMANN, 2010).

Segundo Chin (2003), procedimentos de blindfolding consideram blocos de $N$ casos e $K$ indicadores, utilizando uma distância de omissão $D$. O primeiro ponto (caso 1 e indicador 1) é removido e a cada $D$ casos mais um ponto é removido e 
sucessivamente até o final da matriz. Com os dados que sobrarem na matriz, são feitas estimativas. Quanto aos dados que foram retirados, existem procedimentos de tratamento dos dados omitidos, como por exemplo substituição pela média, deleção simples ou por previsão. A soma dos quadrados do erro previsto $(E)$ é calculada quando o dado omitido é previsto. A soma dos quadrados dos erros calculada, utilizando a previsão média $(O)$, é também calculada. O dado omitido é então retornado e se parte para o próximo ponto da matriz (caso 1 e indicador 2) dando início a uma nova série de omissões. Um novo $E$ e $O$ são calculados. Isso é executado até que o conjunto de Es e Os sejam obtidos com base na distância $D$. O $Q^{2}$ fornece uma medida de extensão que se refere ao quanto essa previsão foi bem sucedida. A medida preditiva é dada pela equação (4.11):

$$
Q^{2}=1-\frac{\sum_{D} E_{D}}{\sum_{D} O_{D}}
$$

Onde:

$E=$ soma dos quadrados do erro previsto quando um dado $D$ é omitido.

$O=$ soma dos quadrados do erro calculado utilizando a previsão média.

$D=$ Distância .

$Q^{2}=$ Medida de extensão que se refere ao quanto essa previsão foi bem sucedida.

Hair et al. (2011) sugerem que a distância $D$ para a omissão dos dados deva ser entre 5 e 10.

Valores positivos de $Q^{2}$ confirmam a relevância preditiva do modelo com respeito a um dado constructo. $Q^{2} \leq 0$ indica que o modelo não possui relevância preditiva (CHIN, 1998). Quanto mais alto o valor de $Q^{2}$, melhor é a sua relevância preditiva (URBACH e AHLEMANN, 2010).

Hair et al. (2011) recomendam usar o índice de redundância cruzada (cross-validated redundancy) do teste $Q^{2}$, porque ele utiliza as estimativas da PLS-SEM para ambos os modelos, estrutural e de mensuração, para prever os dados. Se o índice para um constructo endógeno for maior que zero, existe 
relevância preditiva. Se $\circ$ valor $Q^{2}=1$, as variáveis endógenas podem ser perfeitamente reconstruídas pelo modelo (FORNELL e BOOKSTEIN, 1982).

A validade dos resultados da PLS-SEM pode ser prejudicada pela heterogeneidade das observações, pois parâmetros distintos podem ocorrer para subpopulações diferentes. No entanto, as fontes efetivas de heterogeneidade nem sempre podem ser reconhecidas num primeiro momento, caso em que se denomina heterogeneidade não observada (HAIR et al., 2011).

Este fenômeno deve ser investigado como análise suplementar do modelo estrutural, pois a heterogeneidade não observada pode comprometer os resultados, a interpretação e as conclusões do estudo (HAIR et al., 2012). A técnica abaixo descrita permite verificar se os resultados estão sendo distorcidos por heterogeneidade não observada e também identificar variáveis até então negligenciadas (HAIR et al., 2011).

A abordagem disponível no software SmartPLS versão 2.0 é a técnica de mistura de mínimos quadrados parcial conhecida como FIMIX-PLS. Baseada em regressão, a técnica estima simultaneamente os parâmetros do modelo estrutural e avalia a heterogeneidade da estrutura dos dados, calculando a probabilidade de uma observação pertencer a um dado segmento (HAIR et al., 2012). Ao agrupar as observações e estimar os parâmetros simultaneamente, os vieses que podem ocorrer quando os modelos são estimados em separado são evitados (SARSTEDT e RINGLE, 2010). As observações são agrupadas segundo o número de classes que melhor adequem à sua distribuição com estimativas distintas para os caminhos do modelo estrutural.

Para que o procedimento FIMIX-PLS possa calcular a probabilidade das observações pertencerem a cada um dos segmentos, o seu número deve ser predeterminado. Assim, uma decisão crucial que o pesquisador precisa tomar é de quantos segmentos manter. Para isso, Sarstedt e Ringle (2010) sugerem que sejam testados números alternativos de segmentos e escolhido aquele que tenha o menor valor dos seguintes critérios: Consistent Akaike Information Criterion CAIC e Bayes Information Criterion - BIC. Paralelamente, deve-se examinar o valor normalizado de entropia $(E N)$, que varia entre 0 e 1. Quanto mais distinta é a separação das classes, maior o valor do critério $E N$. Segundo os autores, valores próximos a 0,50 indicam classes bem distintas (SARSTEDT e RINGLE, 2010). 
Uma vez definidos os segmentos (Clusters), outro teste que pode ser realizado para analisar as discrepâncias entre os valores observados para os diferentes clusters é a análise de variância $\left(\right.$ ANOVA $\left.^{29}\right)$. Esta análise foi realizada com a ajuda do software estatístico Statistical Package for Social Sciences (SPSS) versão 20.0 para verificar a significância estatística das diferenças entre as médias das respostas dadas a todos os itens.

Segundo Urbach e Ahlemann (2010), se ao final das análises recomendadas todas as medidas de validação relevantes produzirem resultados aceitáveis, as estimativas dos parâmetros podem ser interpretadas com base nos fundamentos teóricos do modelo de equações estruturais. Consequentemente, as hipóteses expressas pelo modelo estrutural podem ser rejeitadas ou não. $O$ modelo final, portanto, permite ao pesquisador responder a suas perguntas de pesquisa, tirar conclusões e derivar implicações para a teoria e prática.

\footnotetext{
${ }^{29}$ ANOVA é um termo utilizado para a análise de variância que compara médias de diferentes populações para verificar se essas populações possuem médias iguais ou não. Assim, essa técnica permite que vários grupos sejam comparados a um só tempo (TABACHNICK e FIDELL, 2007).
} 


\section{RESULTADOS}

Os resultados da etapa conclusivo-descritiva da pesquisa de campo dividem-se em: (1) análise descritiva da amostra; (2) análises da escala; (3) teste do outer model (modelo de mensuração); (4) teste do inner model (modelo estrutural) e das hipóteses sobre as relações entre as variáveis latentes (GALHANONE, 2013).

\subsection{Preparação do banco de dados}

Antes de iniciar o trabalho de análises estatísticas, os dados colhidos em campo foram verificados. Seguindo a indicação de Hair et al. (2006), os respondentes que apresentassem respostas com mais de $15 \%$ de em branco deveriam ser eliminados. Também deveriam ser excluídos os casos que apresentassem respostas repetidas com frequência e casos em que as perguntas fossem respondidas em um tempo excessivamente curto, indicando que 0 respondente não realizou a tarefa com a devida seriedade e atenção.

Nessa análise não foram encontrados questionários com respostas em branco, porém foram eliminados 8 casos, que apresentaram uma grande quantidade de respostas repetidas. $O$ banco de dados final teve um total de 171 respondentes, os quais foram considerados para as análises univariada e multivariada.

\subsection{Análise univariada}

A análise univariada ou descritiva da amostra compreende a caracterização do perfil dos respondentes.

\subsubsection{Perfil da amostra}

As análises descritivas da amostra que caracterizam 0 perfil do respondente estão abaixo descritas e representadas em seis tabelas. Os cálculos e as tabelas foram desenvolvidos utilizando o software MS-Excel. 
A TAB.5.1 apresenta a idade dos respondentes. A FIG.5.1 apresenta um gráfico com a projeção da faixa etária dos funcionários do IPEN.

TABELA 5.1 - Idade dos respondentes

\begin{tabular}{lcc}
\multicolumn{3}{c}{ Idade } \\
\hline & Frequência & Percentual \\
26 a 35 anos & 7 & $4 \%$ \\
36 a 45 anos & 22 & $13 \%$ \\
46 a 55 anos & 90 & $53 \%$ \\
57 a 65 anos & 43 & $25 \%$ \\
Acima de 65 anos & 9 & $5 \%$ \\
\hline Total & $\mathbf{1 7 1}$ & $\mathbf{1 0 0} \%$ \\
\hline
\end{tabular}

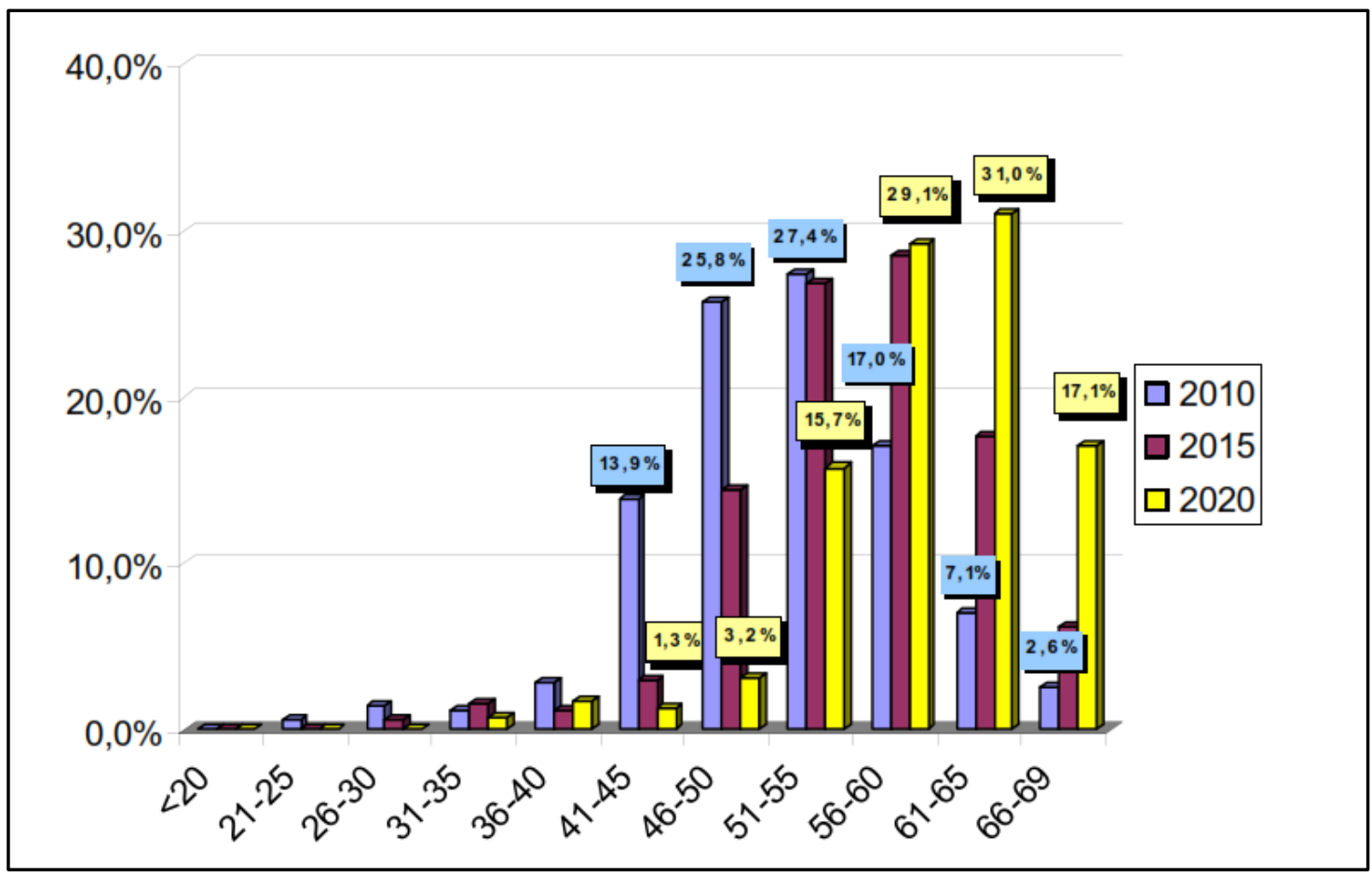

Fonte: (IPEN / CNEN, 2011)

FIGURA 5.1- Projeção da distribuição por faixa etária do IPEN

Em termos de faixa etária, a amostra obtida caracterizou-se por uma grande concentração na faixa entre 46 e 55 anos (53\%). Isso condiz com o percentual apresentado no site do IPEN quanto à sua população atual e projeção para 2015 e 2020. Uma possível explicação para isso é que, por ser uma instituição federal, o IPEN proporciona estabilidade a seus funcionários e, por isso o quadro tem se mantido estável, sem muitas contratações. Também os 
funcionários contratados no passado tendem a ficar na instituição, envelhecendo com ela.

Na TAB.5.2 é apresentado o Centro de Pesquisa a que pertencem os respondentes. Pode-se observar que 35\% da amostra não estão alocadas a nenhum Centro de Pesquisa. Esses respondentes são pessoas do IPEN que pertencem a áreas de apoio como, segurança, administração, infraestrutura, ensino, produtos e serviços, planejamento e gestão. $65 \%$ dos respondentes estão alocados em algum centro de pesquisa do IPEN.

TABELA 5.2 - Centro de pesquisa dos respondentes

\begin{tabular}{ccc}
\multicolumn{3}{c}{ Centro } \\
Outro & Frequência & Percentual \\
CEN & 59 & $35 \%$ \\
CRPq & 24 & $14 \%$ \\
CR & 23 & $13 \%$ \\
COMA & 11 & $6 \%$ \\
CTR & 9 & $5 \%$ \\
CCN & 9 & $5 \%$ \\
CCTM & 7 & $5 \%$ \\
CB & 6 & $4 \%$ \\
CLA & 6 & $4 \%$ \\
CCCH & 5 & $4 \%$ \\
CEI & 4 & $3 \%$ \\
\hline Total & $\mathbf{1 7 1}$ & $\mathbf{1 0 0} \%$ \\
\hline
\end{tabular}

A TAB.5.3 demonstra a função que os respondentes ocupam no IPEN. A maioria dos respondentes tem função de tecnologista (39\%). O tecnologista é um profissional com nível superior ou pós-graduado que desempenha funções operacionais. O pesquisador que representa 19\% dos respondentes, também possui nível superior ou pós-graduação, mas está focado basicamente em atividades de pesquisa e pode também prestar orientações aos alunos. Os respondentes que pertencem à função técnica representam os funcionários que exercem funções operacionais (19\%). Os funcionários administrativos estão representados por aqueles que podem ou não ter nível superior e exercem atividades de apoio à instituição, como secretárias e pessoas que trabalham no 
departamento pessoal. Do total dos respondentes, $9 \%$ estão alocados em cargos de gestão.

TABELA 5.3 - Função dos respondentes

\begin{tabular}{lcc} 
& Função & \\
& Frequência & Percentual \\
Tecnologista & 66 & $39 \%$ \\
Pesquisador & 33 & $19 \%$ \\
Função Técnica & 32 & $19 \%$ \\
Administrativa & 25 & $15 \%$ \\
Gestor & 15 & $9 \%$ \\
\hline Total Geral & $\mathbf{1 7 1}$ & $\mathbf{1 0 0} \%$ \\
\hline
\end{tabular}

Os dados relativos ao sexo dos respondentes são apresentados na TAB.5.4, que mostra uma predominância masculina com $66 \%$ da amostra.

TABELA 5.4 - Sexo dos respondentes

\begin{tabular}{lcc} 
& Sexo \\
& Frequência & Percentual \\
Masculino & 113 & $66 \%$ \\
Feminino & 58 & $34 \%$ \\
\hline Total & $\mathbf{1 7 1}$ & $\mathbf{1 0 0} \%$ \\
\hline
\end{tabular}

O perfil da amostra revela também que se trata de respondentes com grau educacional elevado. Uma parcela menor deles (4\%) cursou somente até o ensino médio, enquanto que 35\% tem grau de doutorado (TAB.5.5 TABELA 5.5).

TABELA 5.5 - Grau de instrução dos respondentes

\begin{tabular}{lcc}
\hline \multicolumn{3}{c}{ Grau de Instrução } \\
\hline & Frequência & Percentual \\
Doutorado & 60 & $35 \%$ \\
Graduação & 45 & $26 \%$ \\
Mestrado & 32 & $19 \%$ \\
Pós-doutorado & 17 & $10 \%$ \\
Pós-graduação & 13 & $8 \%$ \\
Médio & 4 & $2 \%$ \\
\hline \multicolumn{1}{c}{ Total Geral } & $\mathbf{1 7 1}$ & $\mathbf{1 0 0} \%$ \\
\hline
\end{tabular}


Na TAB.5.6 é mostrado o tempo em que os respondentes trabalham na instituição. Observa-se que 72\% dos respondentes estão há mais de 20 anos na instituição, sendo que $40 \%$ desses trabalham no IPEN há mais de 30 anos..

TABELA 5.6 - Tempo de instituição dos respondentes

\begin{tabular}{lcc}
\hline & Tempo & \\
& Frequência & Percentual \\
Mais de 30 anos & 68 & $40 \%$ \\
21 a 30 anos & 54 & $32 \%$ \\
11 a 20 anos & 28 & $16 \%$ \\
6 a 10 anos & 4 & $2 \%$ \\
0 a 5 anos & 17 & $10 \%$ \\
\hline Total & $\mathbf{1 7 1}$ & $\mathbf{1 0 0} \%$ \\
\hline
\end{tabular}

Com base na análise univariada até aqui empreendida, pode-se descrever o perfil predominante da amostra, que é formada por indivíduos do sexo masculino, com mais de 20 anos de trabalho na Instituição, com alto nível educacional (doutorado e mestrado). Esses ocupam a função de tecnologista e pesquisadores, com idade acima de 45 anos, alocados em algum centro de pesquisa do IPEN.

\subsubsection{Percepção da amostra quanto à RS do IPEN}

Conforme mencionado no item 4.2.2, a escala utilizada no questionário é do tipo intervalar. Os respondentes devem assinalar os números de 1 a 6 , correspondendo a notas indicativas do grau de importância, de concordância ou discordância, conhecimento ou desconhecimento de cada frase, pressupondo intervalos iguais entre cada nota. $O$ fato da escala adotada ser par impede a neutralidade, ou seja, impede que os respondentes marquem a coluna do meio, como forma de não posicionamento diante de uma determinada questão.

Os dados apresentados abaixo representam a percepção da amostra dos 171 respondentes com relação às dimensões da responsabilidade social do IPEN. As figuras e as tabelas foram desenvolvidas utilizando o software MS-Excel. 


\section{Percepção da RS do IPEN por sexo}

Nas FIG.5.2 até FIG.5.8 são mostradas as análises das dimensões da RS do IPEN com base no sexo dos respondentes. O eixo "x" representa a percepção dos respondentes com relação à RS do IPEN na escala de 1 a 6 , e o eixo "y" representa a quantidade de respondentes.

A linha vermelha representa o resultado da avaliação dos respondentes do sexo feminino, e a linha azul representa o resultado da avaliação dos respondentes do sexo masculino para cada uma das dimensões da RS analisadas.

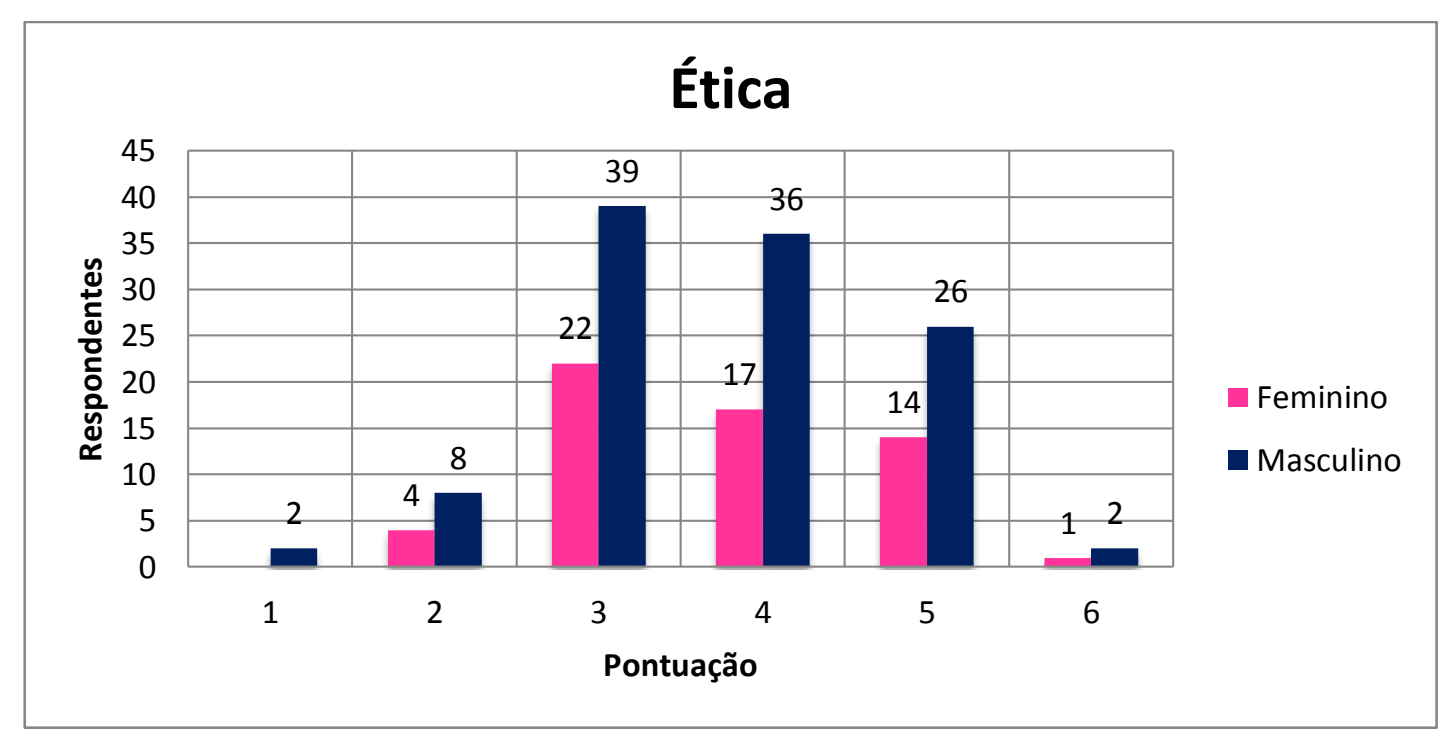

FIGURA 5.2- Avaliação da Ética do IPEN por Sexo

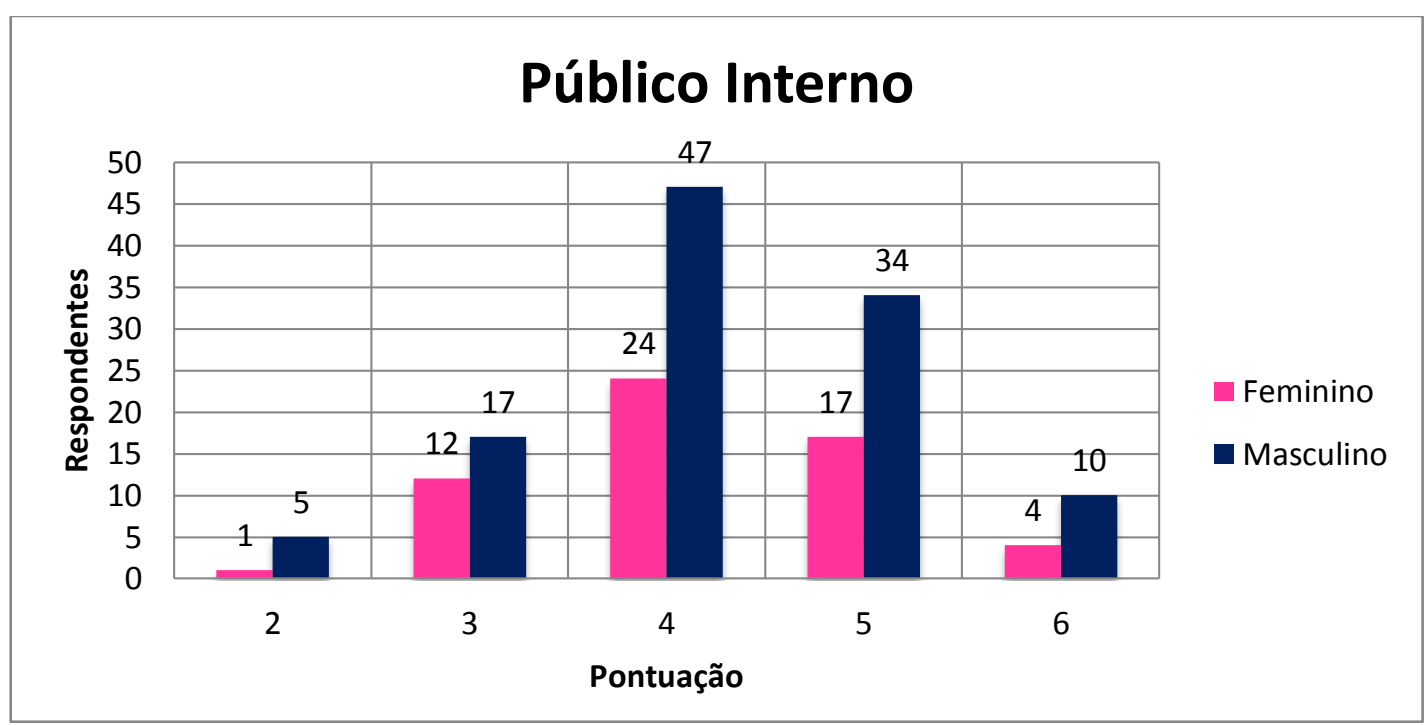

FIGURA 5.3- Avaliação RS do IPEN para com o Público Interno por Sexo 


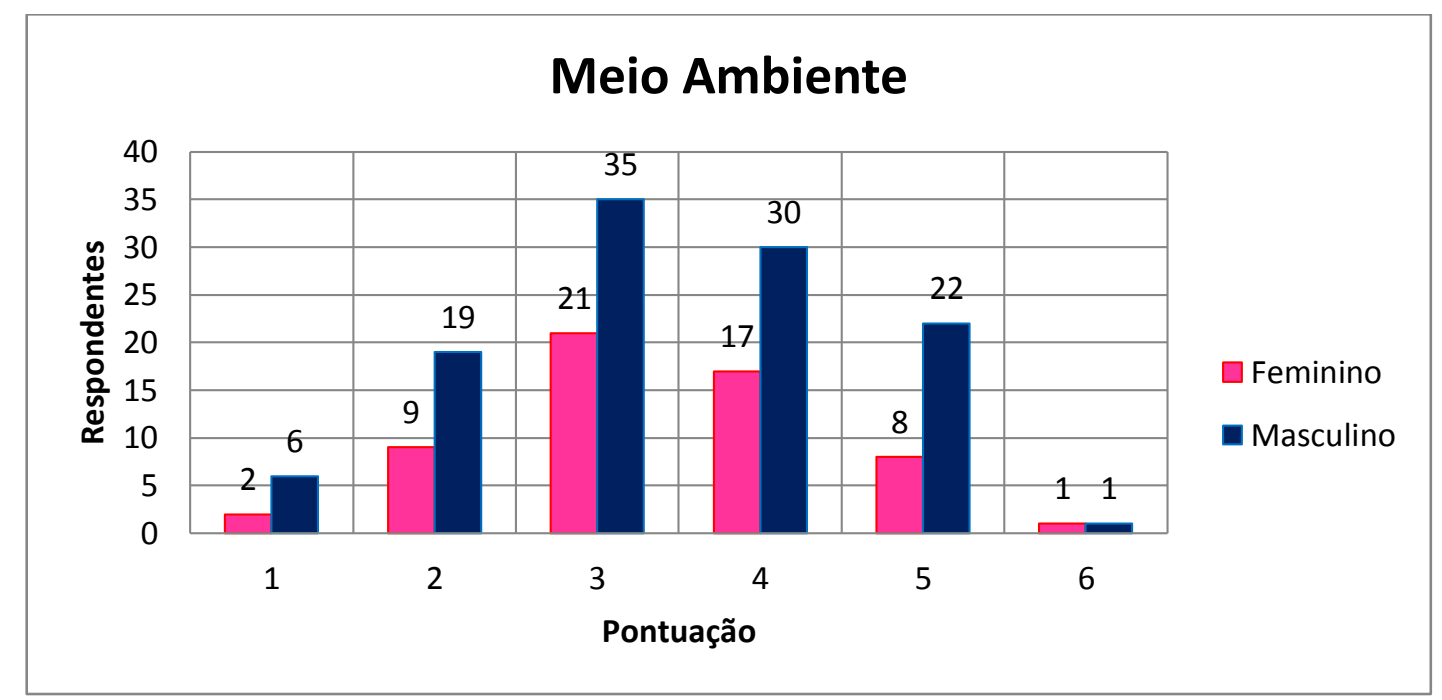

FIGURA 5.4 - Avaliação do Tratamento Dado ao Meio Ambiente pelo IPEN por Sexo

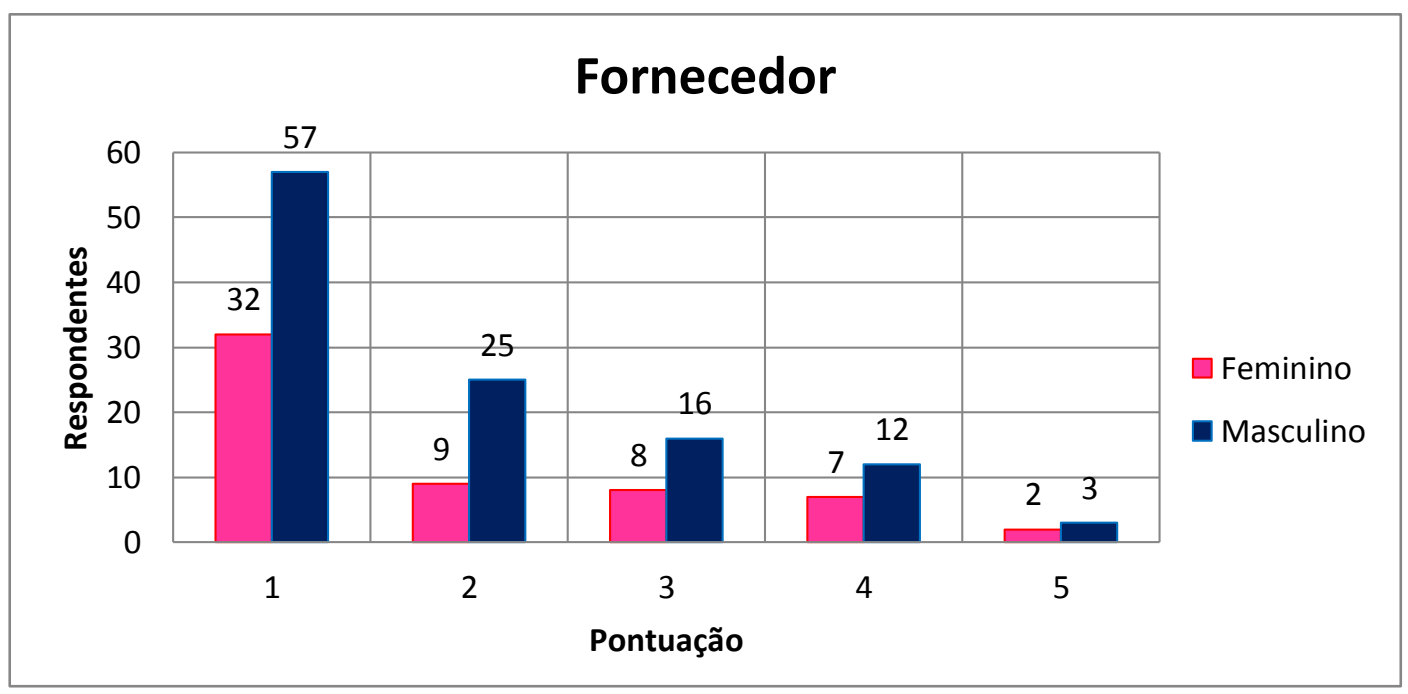

FIGURA 5.5 - Avaliação do Relacionamento do IPEN com os Fornecedores por Sexo

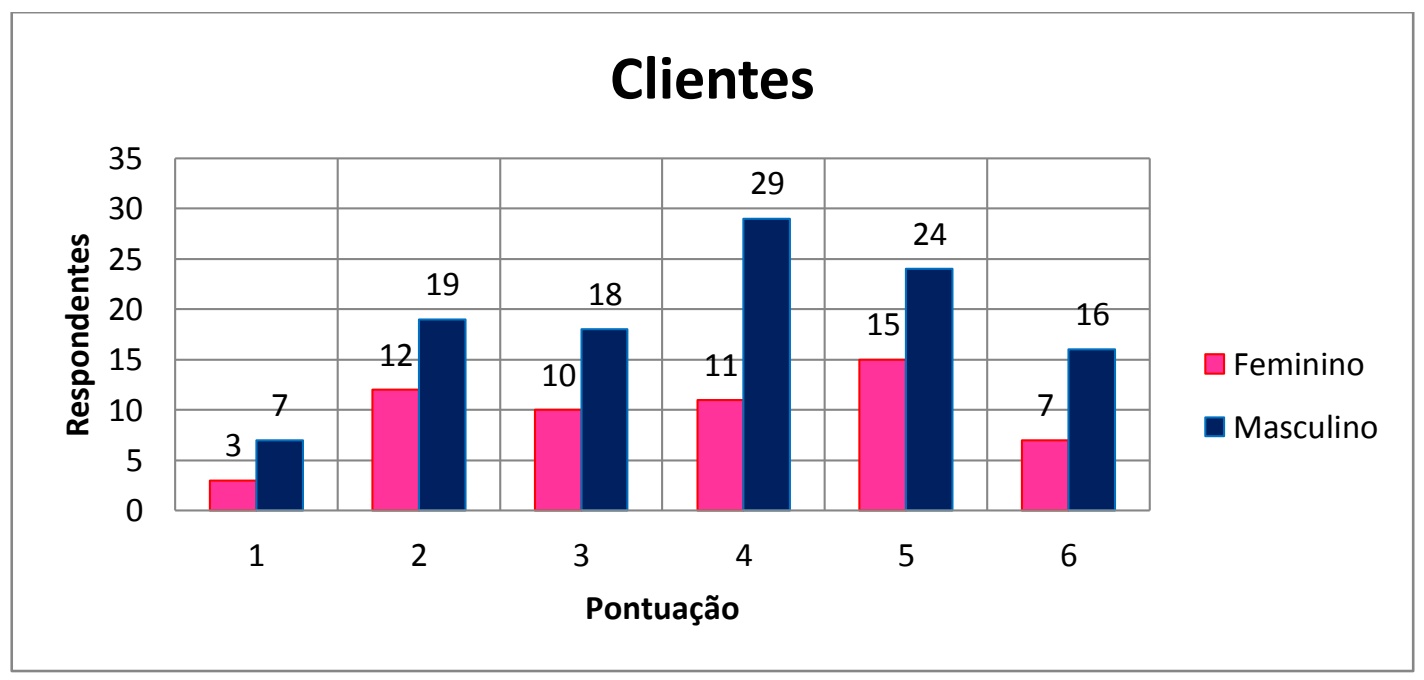

FIGURA 5.6 - Avaliação do Relacionamento do IPEN com os seus Clientes por Sexo 


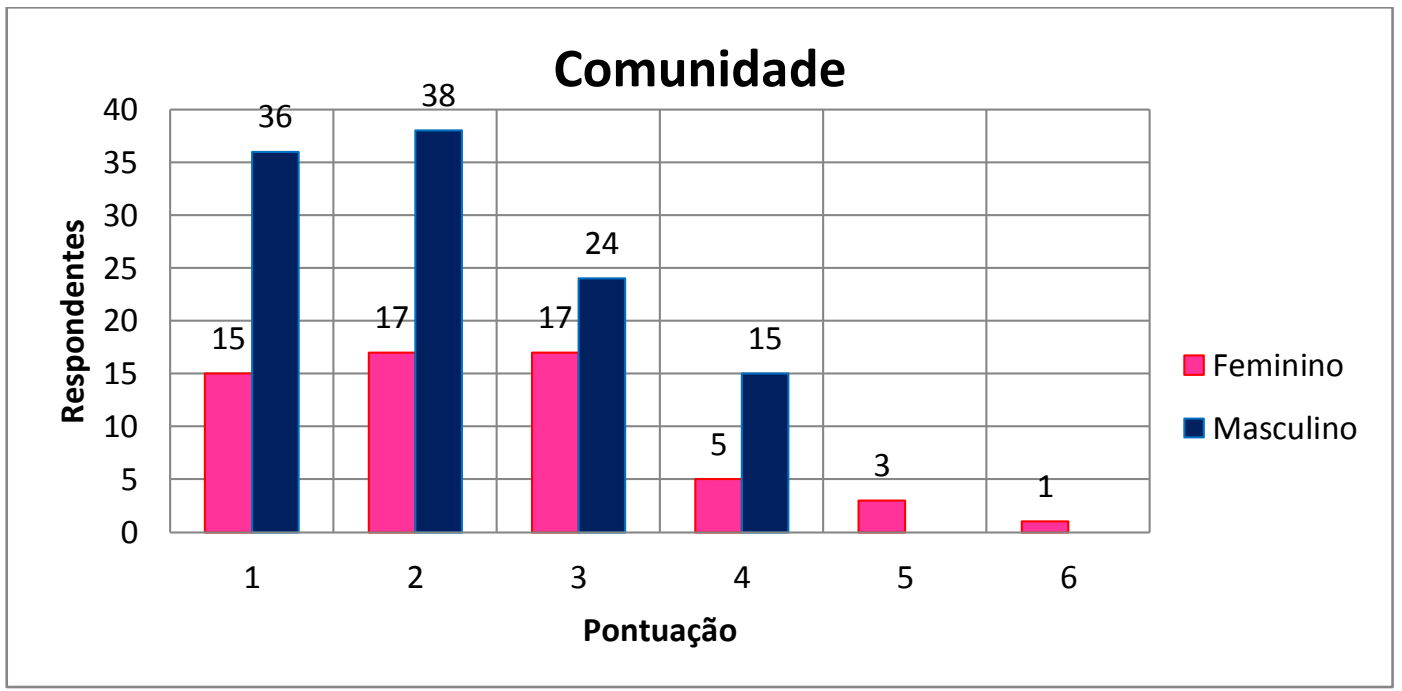

FIGURA 5.7- Avaliação do Relacionamento do IPEN com a Comunidade do Entorno por Sexo

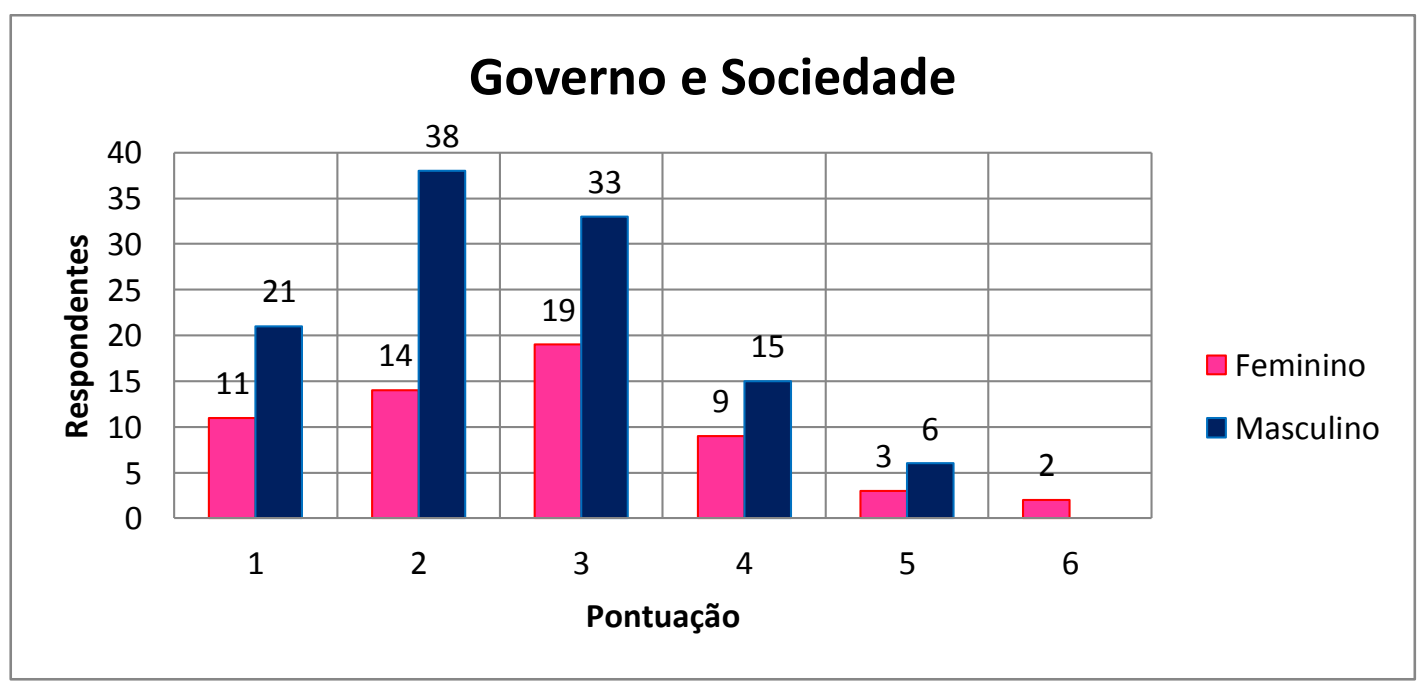

FIGURA 5.8 - Avaliação do Relacionamento do IPEN com o Governo e a Sociedade por Sexo

Considerando-se o sexo, observa-se que o comportamento da amostra com relação às dimensões da RS do IPEN segue o mesmo padrão de pontuação tanto para os respondentes do sexo masculino quanto para os respondentes do sexo feminino.

As dimensões público interno, cliente e ética obtiveram média quatro para ambos os sexos. As dimensões meio ambiente e governo/sociedade obtiveram média três para ambos os sexos e as dimensões comunidade e fornecedor obtiveram média dois para ambos os sexos. 
Na TAB.5.7 é apresentada a pontuação média obtida por cada dimensão da RS com base no sexo dos respondentes.

TABELA 5.7 - Pontuação média por sexo

\begin{tabular}{ccc}
\hline Dimensões & Feminino & Masculino \\
\hline Público Interno & 4 & 4 \\
Cliente & 4 & 4 \\
Ética & 4 & 4 \\
Meio Ambiente & 3 & 3 \\
Governo e Sociedade & 3 & 3 \\
Comunidade & 2 & 2 \\
Fornecedor & 2 & 2 \\
\hline Média Total & $\mathbf{3}$ & $\mathbf{3}$ \\
\hline
\end{tabular}

\section{Percepção da RS do IPEN por idade}

Nas FIG.5.9 até FIG.5.15 são apresentadas as análises das dimensões da RS do IPEN com base na idade dos respondentes. O eixo " $x$ " representa a percepção dos respondentes com relação à RS do IPEN na escala de 1 a 6, e o eixo "y" representa a quantidade de respondentes. Cada linha/cor representa a faixa etária de cada um dos respondentes.

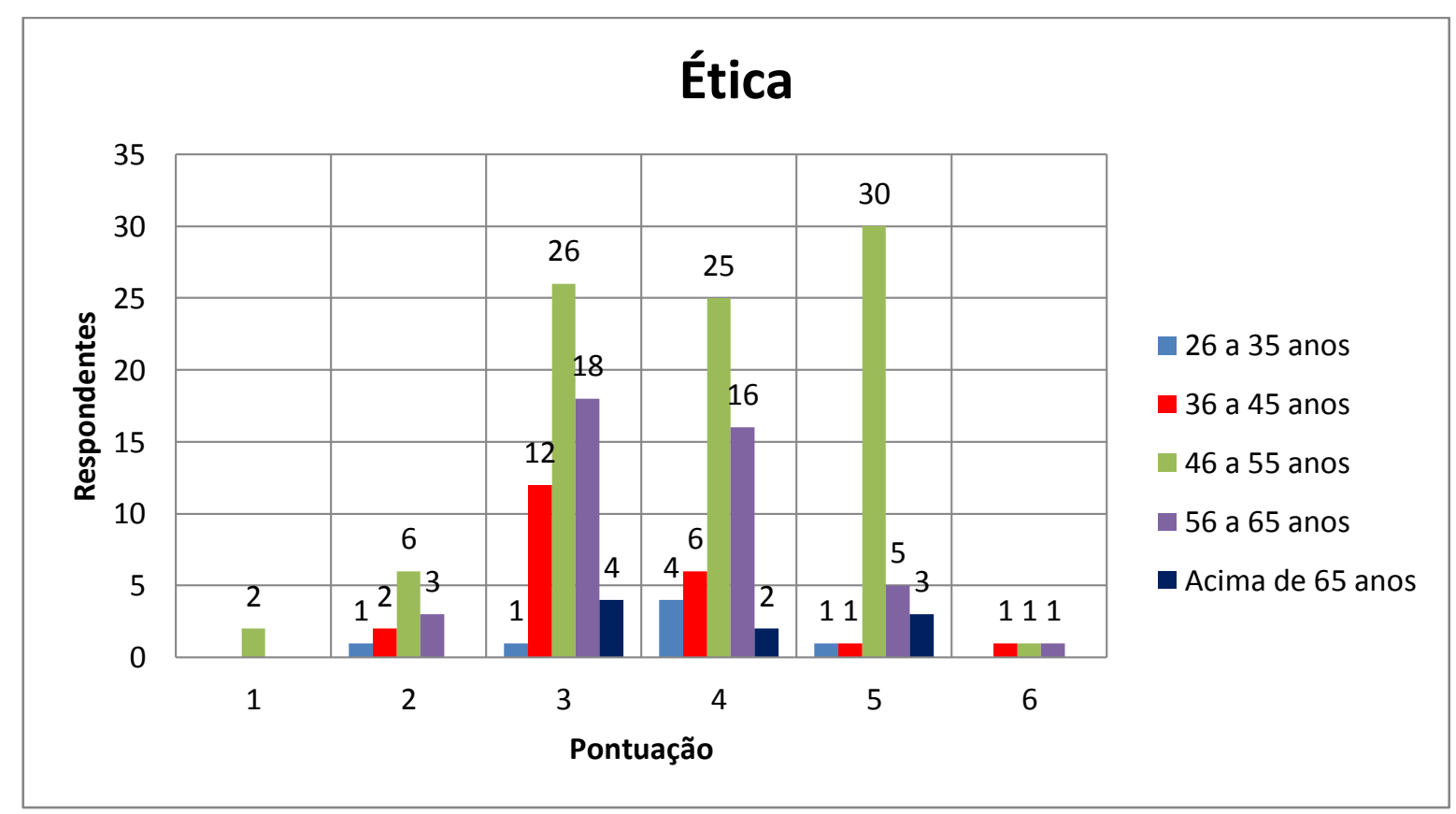

FIGURA 5.9 - Avaliação da Ética do IPEN por Faixa Etária 


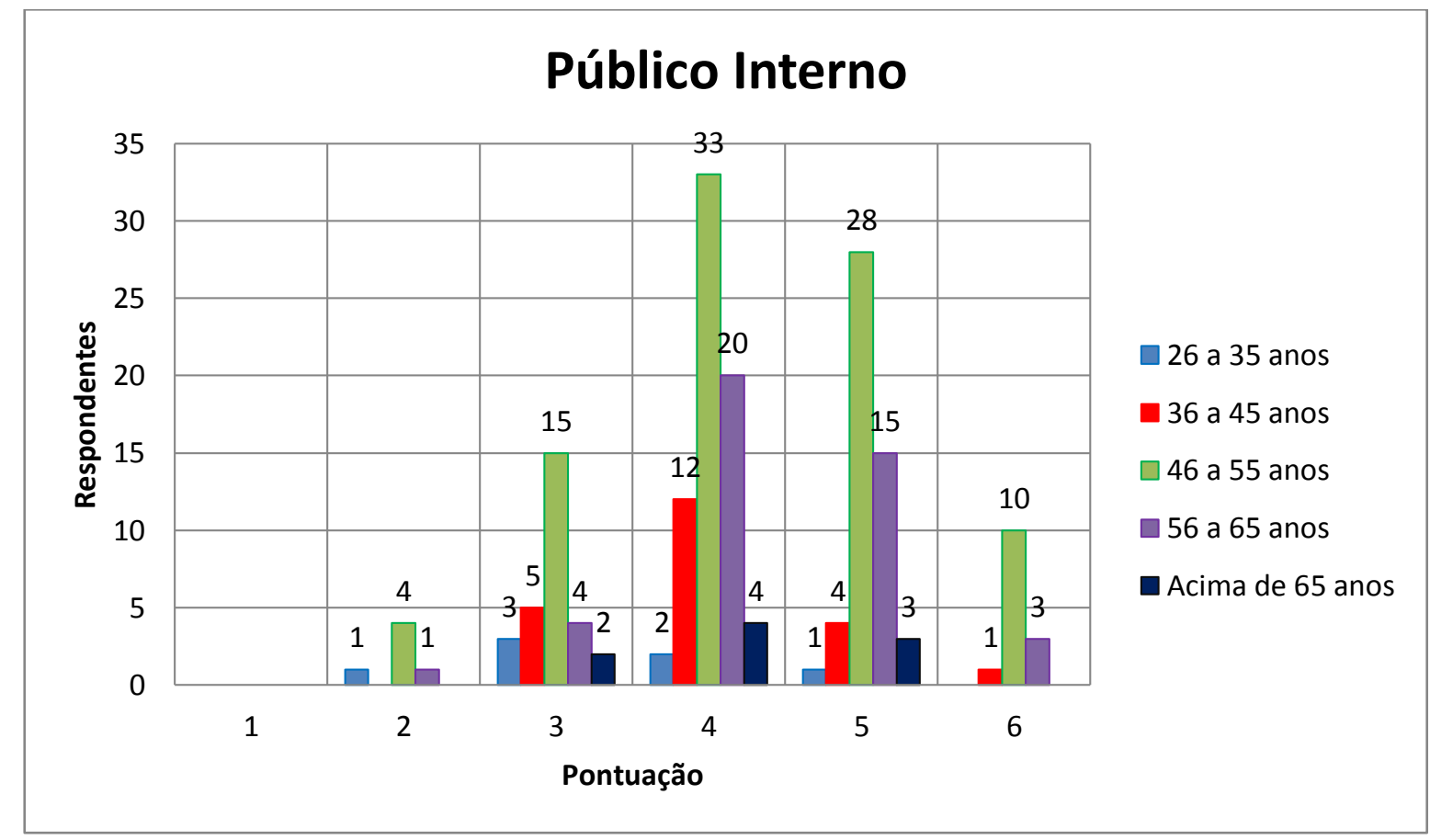

FIGURA 5.10 - Avaliação RS do IPEN para com o Público Interno por Idade

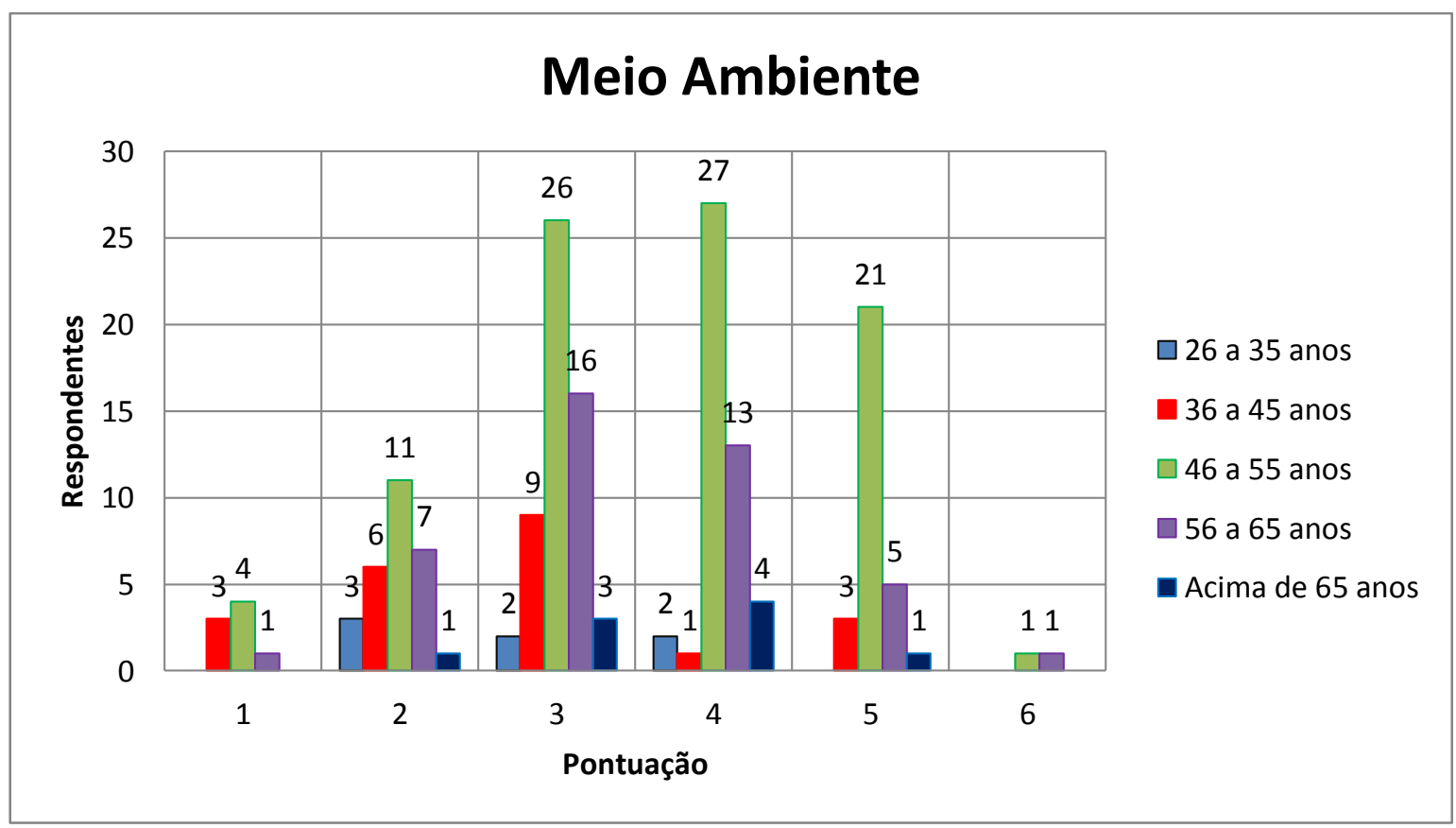

FIGURA 5.11 - Avaliação do Tratamento ao Meio Ambiente Dado pelo IPEN por Idade 


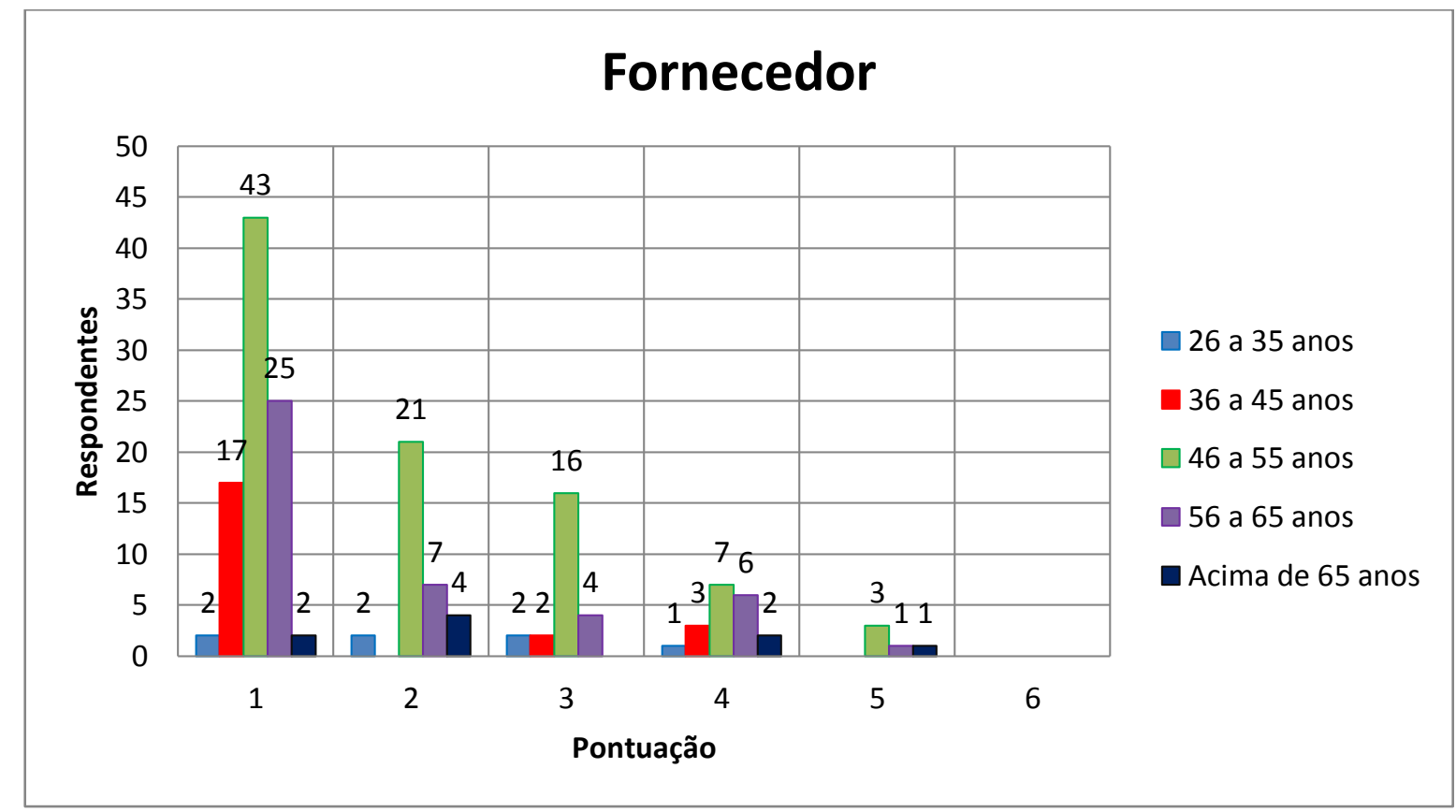

FIGURA 5.12 - Avaliação do Relacionamento do IPEN com os Fornecedores por Idade

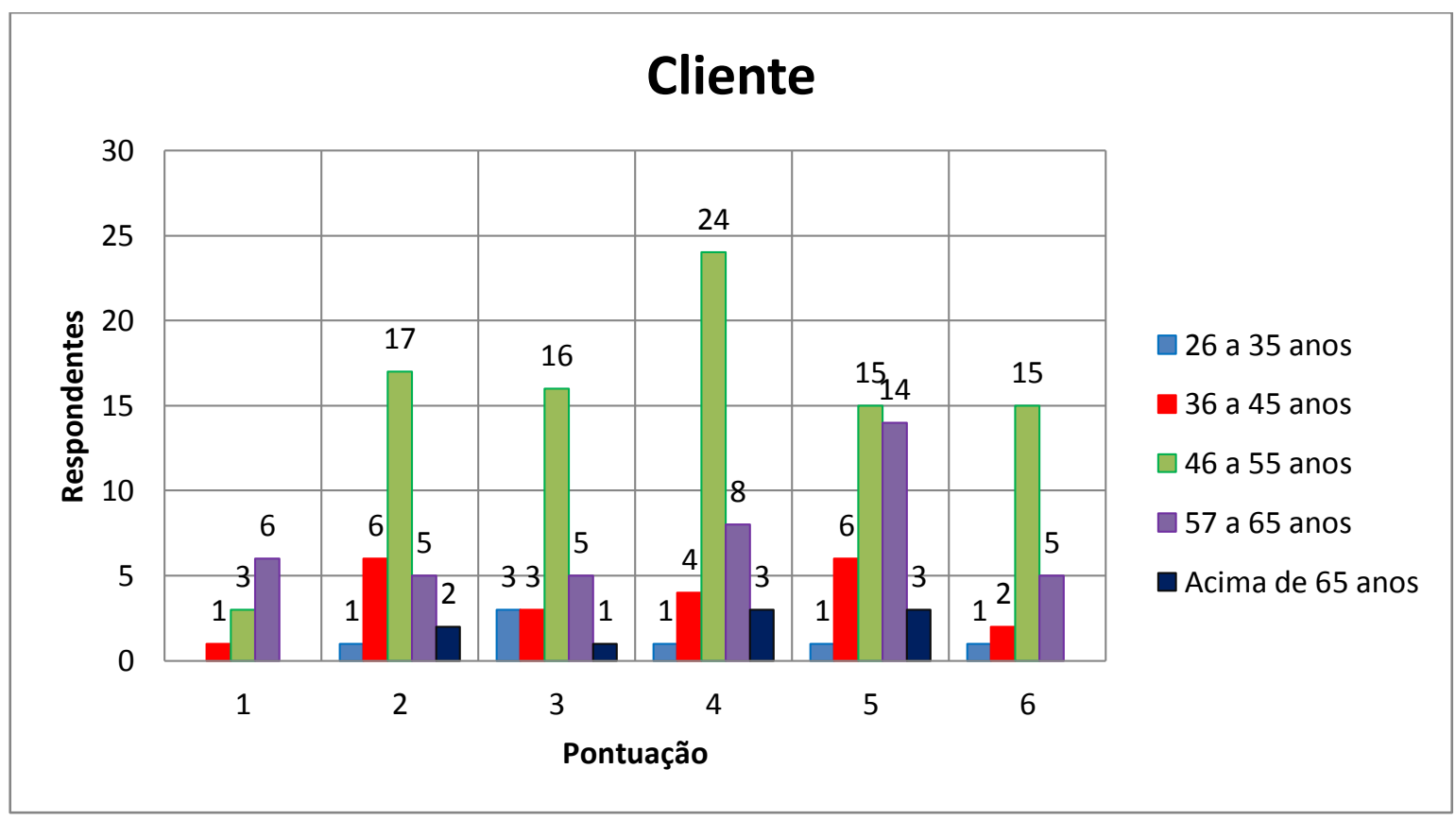

FIGURA 5.13 - Avaliação do Relacionamento do IPEN com os seus Clientes por Idade 


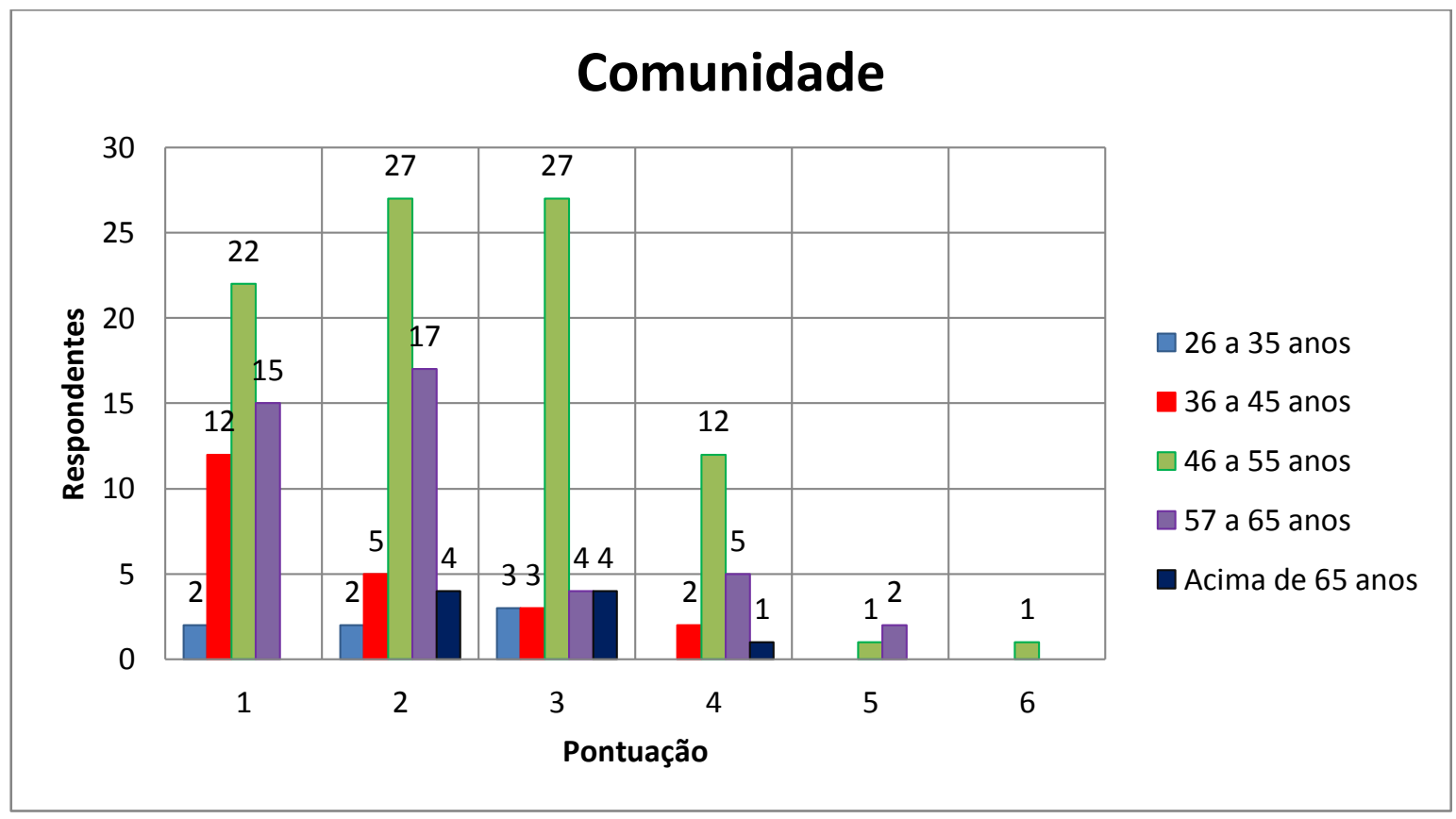

FIGURA 5.14 - Avaliação do Relacionamento do IPEN com a Comunidade do Entorno por ldade

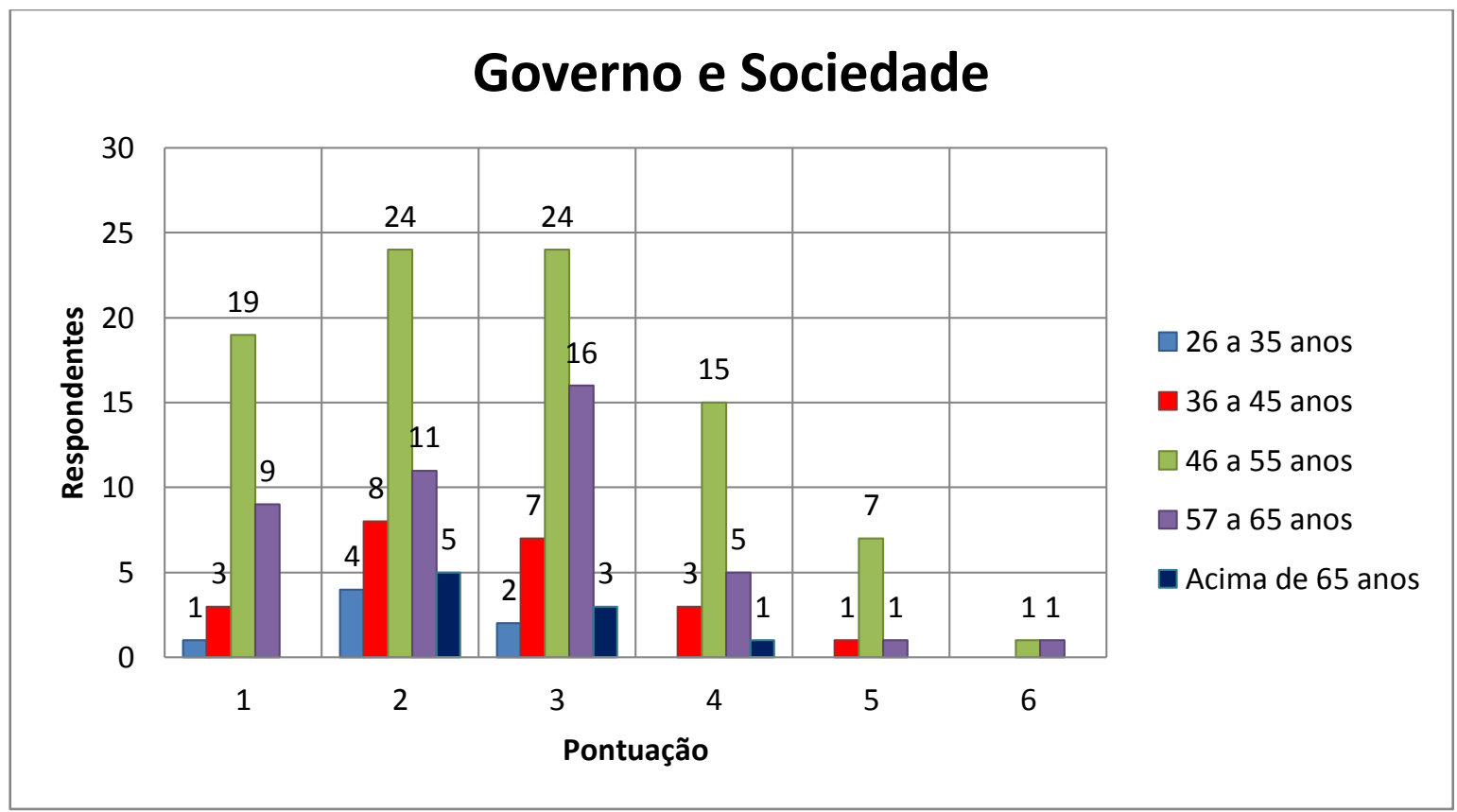

FIGURA 5.15 - Avaliação do Relacionamento do IPEN com o Governo e a Sociedade por Idade

Dependendo da faixa etária, pode-se identificar que a percepção da amostra com relação às dimensões da RS do IPEN segue um padrão de pontuação. Existe uma pequena variação dependendo da faixa etária, porém a 
média geral de todas as idades ficou igual, com o valor médio de três. Os respondentes com faixa etária entre 26 e 35 anos foram os que pior avaliaram o IPEN, e os respondentes com idade acima de 65 anos foram os que melhor avaliaram o IPEN. Um dos possíveis motivos para este resultado decorre da maturidade e o tempo de instituição dos respondentes acima de 65 anos, que tiveram tempo suficiente para enxergar os benefícios que o IPEN proporciona a seus funcionários, principalmente no que se refere a incentivos na pesquisa, suporte financeiro e investimento em treinamentos tanto dentro do Brasil quanto no exterior e além disto, conhecem com mais detalhes todas as dimensões da responsabilidade social abordadas neste estudo.

Na TAB.5.8 a pontuação média obtida para cada dimensão da RS com base na idade dos respondentes é apresentada.

TABELA 5.8 - Pontuação média por faixa etária

\begin{tabular}{lcccccc} 
Dimensões & $\begin{array}{c}\mathbf{2 6} \text { a } \mathbf{3 5} \\
\text { anos }\end{array}$ & $\begin{array}{c}\mathbf{3 6} \text { a } \mathbf{4 5} \\
\text { anos }\end{array}$ & $\begin{array}{c}\mathbf{4 6} \text { a } \mathbf{5 5} \\
\text { anos }\end{array}$ & $\begin{array}{c}\mathbf{5 6} \text { a } \mathbf{6 5} \\
\text { anos }\end{array}$ & $\begin{array}{c}\text { Acima } \\
\text { de } \mathbf{6 5} \\
\text { anos }\end{array}$ & $\begin{array}{c}\text { Média Total } \\
\text { por } \\
\text { Dimensão }\end{array}$ \\
\hline Público Interno & 3 & 4 & 4 & 4 & 4 & 4 \\
Cliente & 4 & 4 & 4 & 4 & 4 & 4 \\
Ética & 4 & 3 & 4 & 4 & 4 & 4 \\
Meio Ambiente & 3 & 3 & 4 & 3 & 4 & 3 \\
Governo/Sociedade & 2 & 2 & 3 & 3 & 3 & 3 \\
Comunidade & 2 & 2 & 2 & 2 & 3 & 2 \\
Fornecedor & 2 & 2 & 2 & 2 & 2 & 2 \\
\hline$\quad$ Média Total por & $\mathbf{3}$ & $\mathbf{3}$ & $\mathbf{3}$ & $\mathbf{3}$ & $\mathbf{3}$ & $\mathbf{3}$ \\
\hline$\quad$ Faixa Etária & & & & & &
\end{tabular}

\section{Percepção da RS do IPEN por tempo de instituição}

Nas FIG.5.16 até FIG.5.22 são apresentadas as análises das dimensões da RS do IPEN com base no tempo de trabalho de cada respondente na instituição. O eixo "x" representa a percepção dos respondentes com relação à RS do IPEN na escala de 1 a 6 , e o eixo "y" representa a quantidade de respondentes. Cada linha/cor representa o tempo de trabalho no IPEN de cada um dos respondentes. 


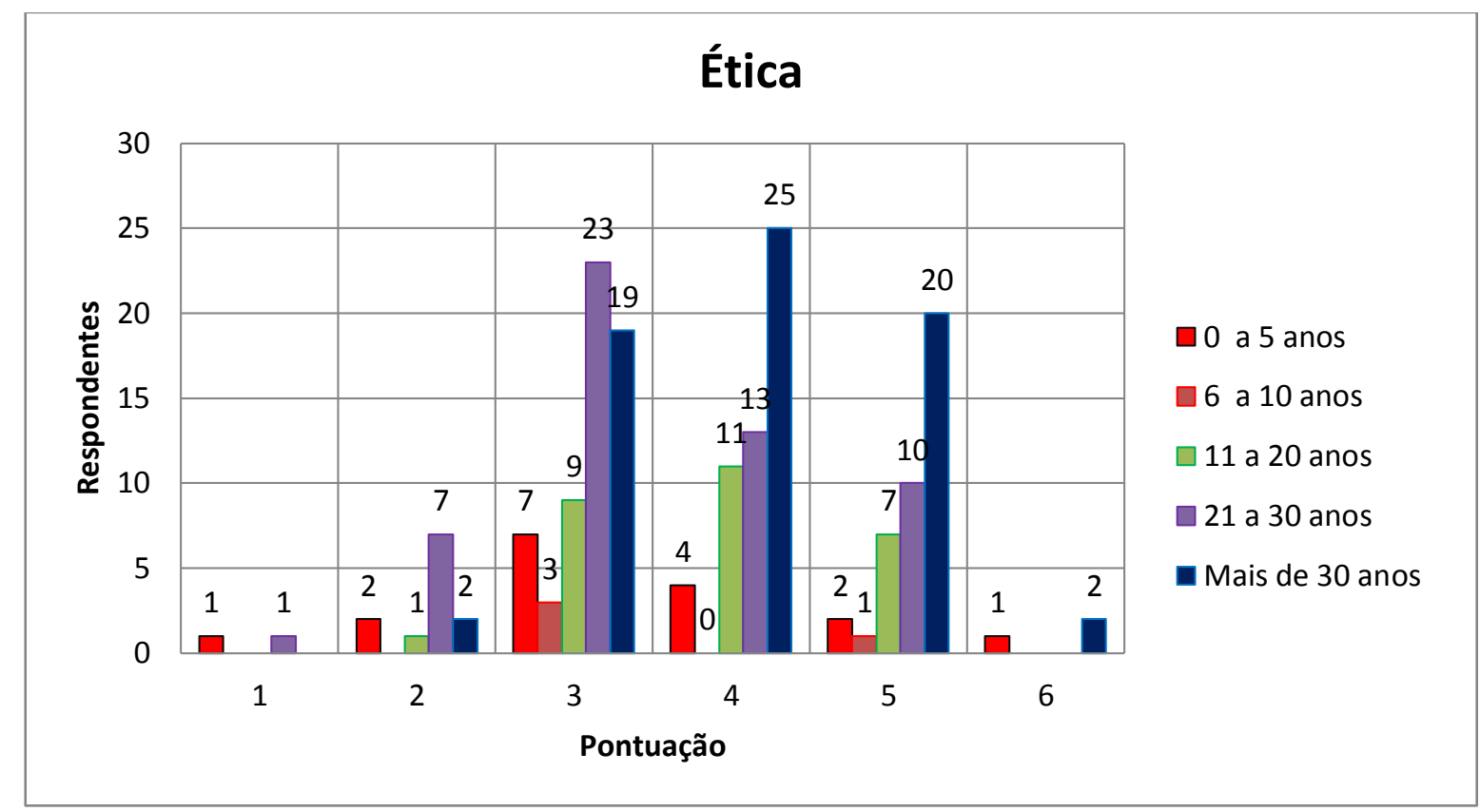

FIGURA 5.16 - Avaliação da Ética do IPEN por Tempo de Trabalho na Instituição

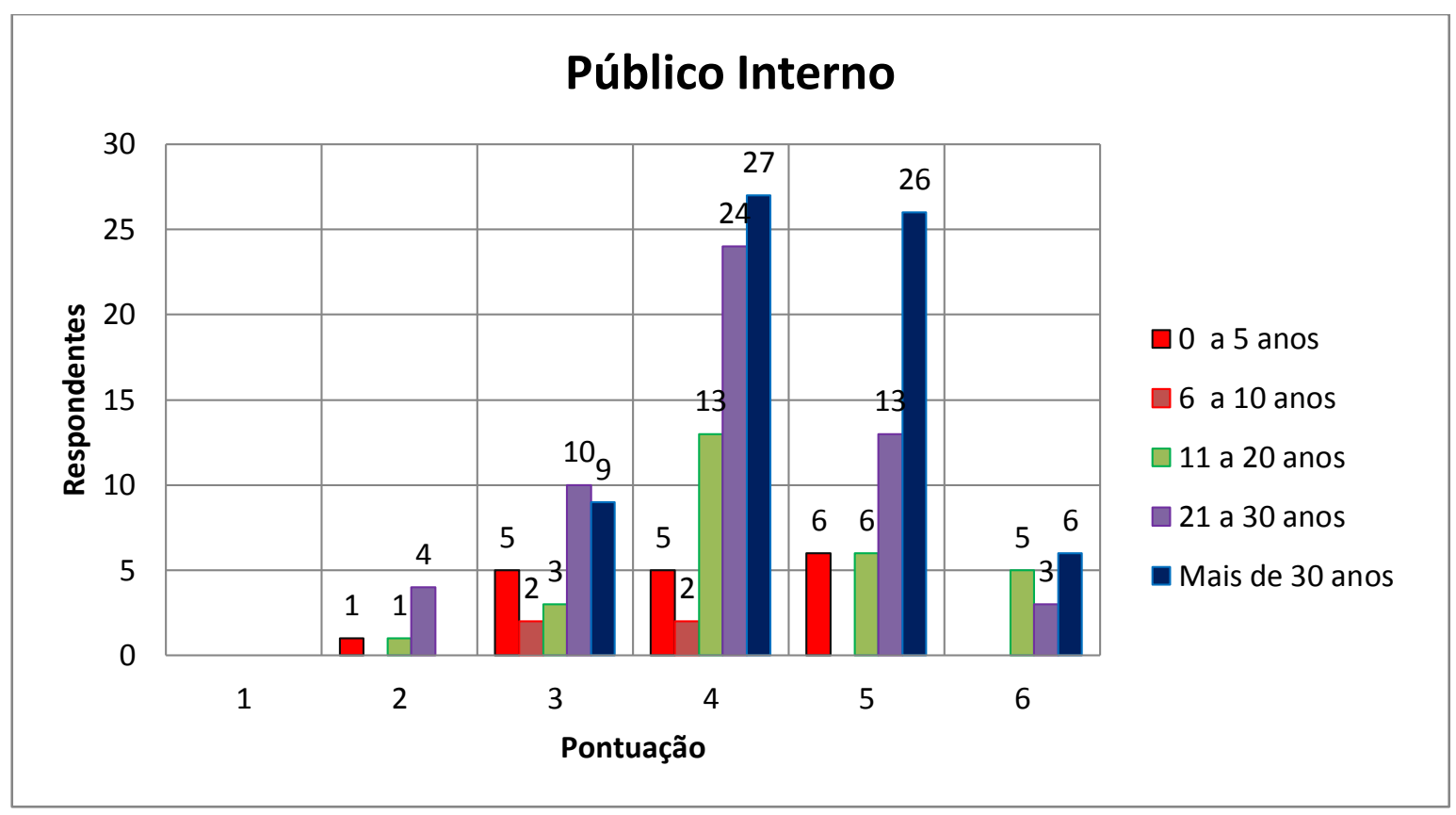

FIGURA 5.17 - Avaliação RS do IPEN para com o Público Interno por Tempo de Trabalho na Instituição 


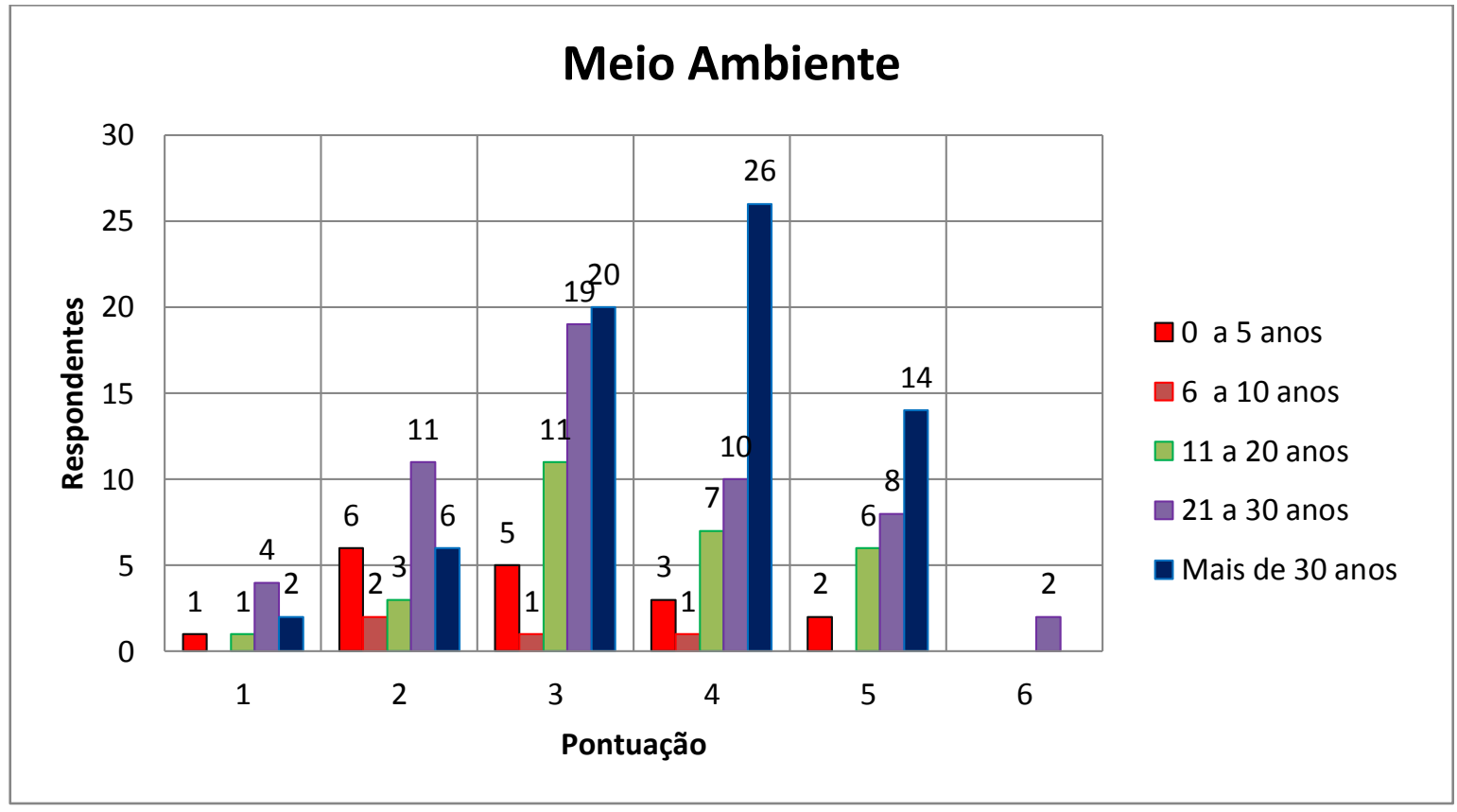

FIGURA 5.18 - Avaliação do Tratamento Dado ao Meio Ambiente pelo IPEN por Tempo de Trabalho na Instituição

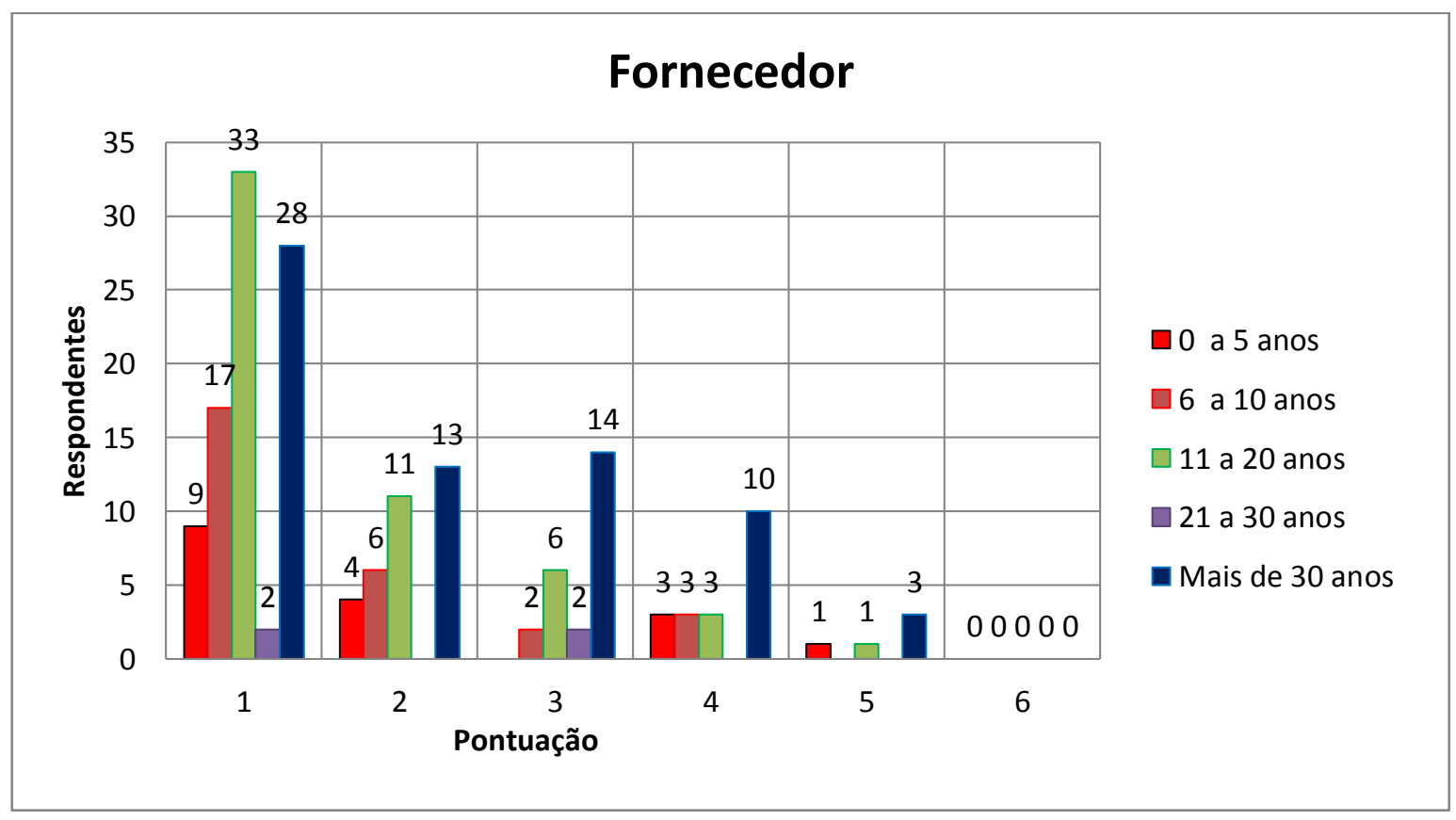

FIGURA 5.19 - Avaliação do Relacionamento do IPEN com os Fornecedores por Tempo de Trabalho na Instituição 


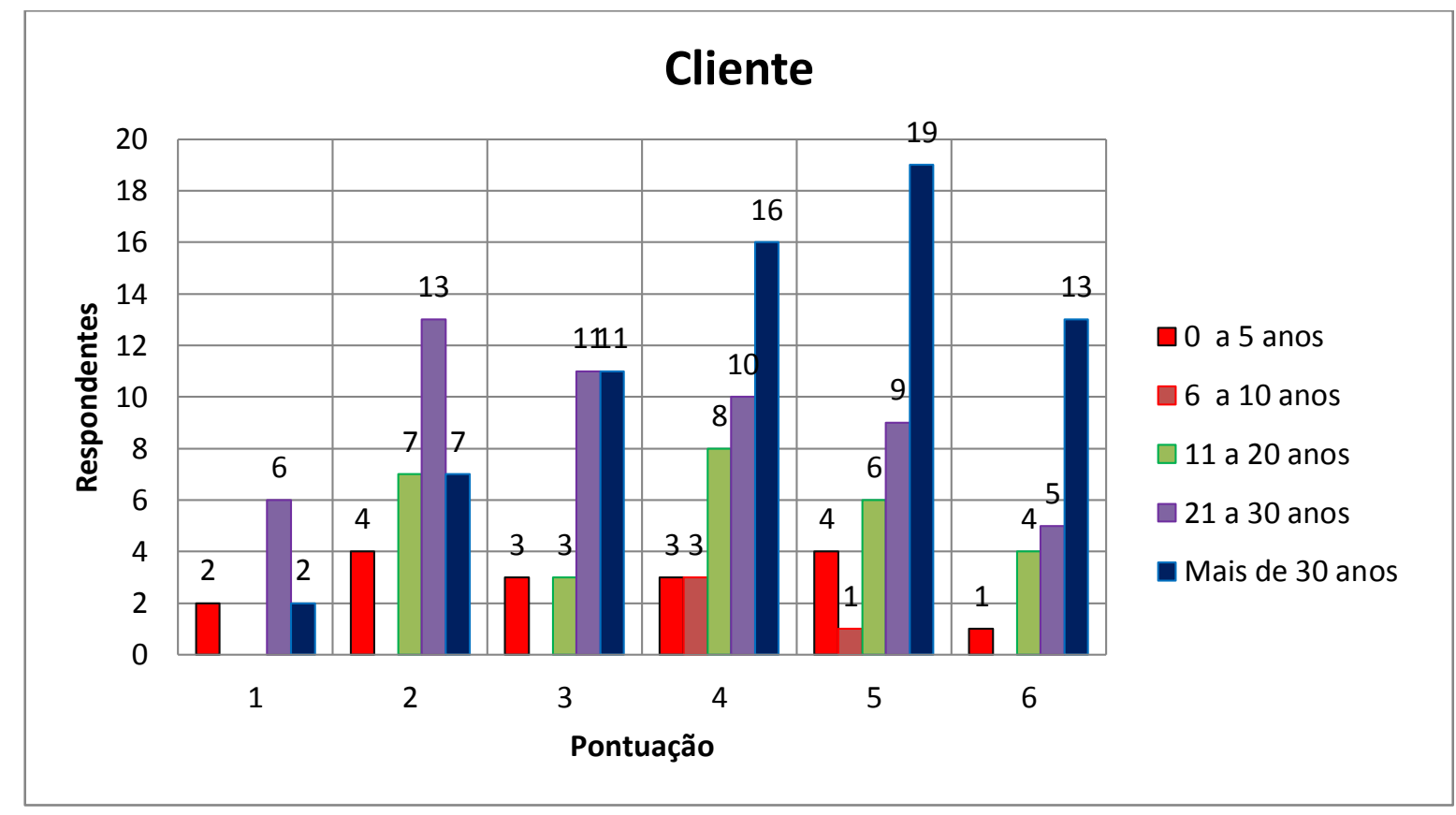

FIGURA 5.20 - Avaliação do Relacionamento do IPEN com os seus Clientes por Tempo de Trabalho na Instituição

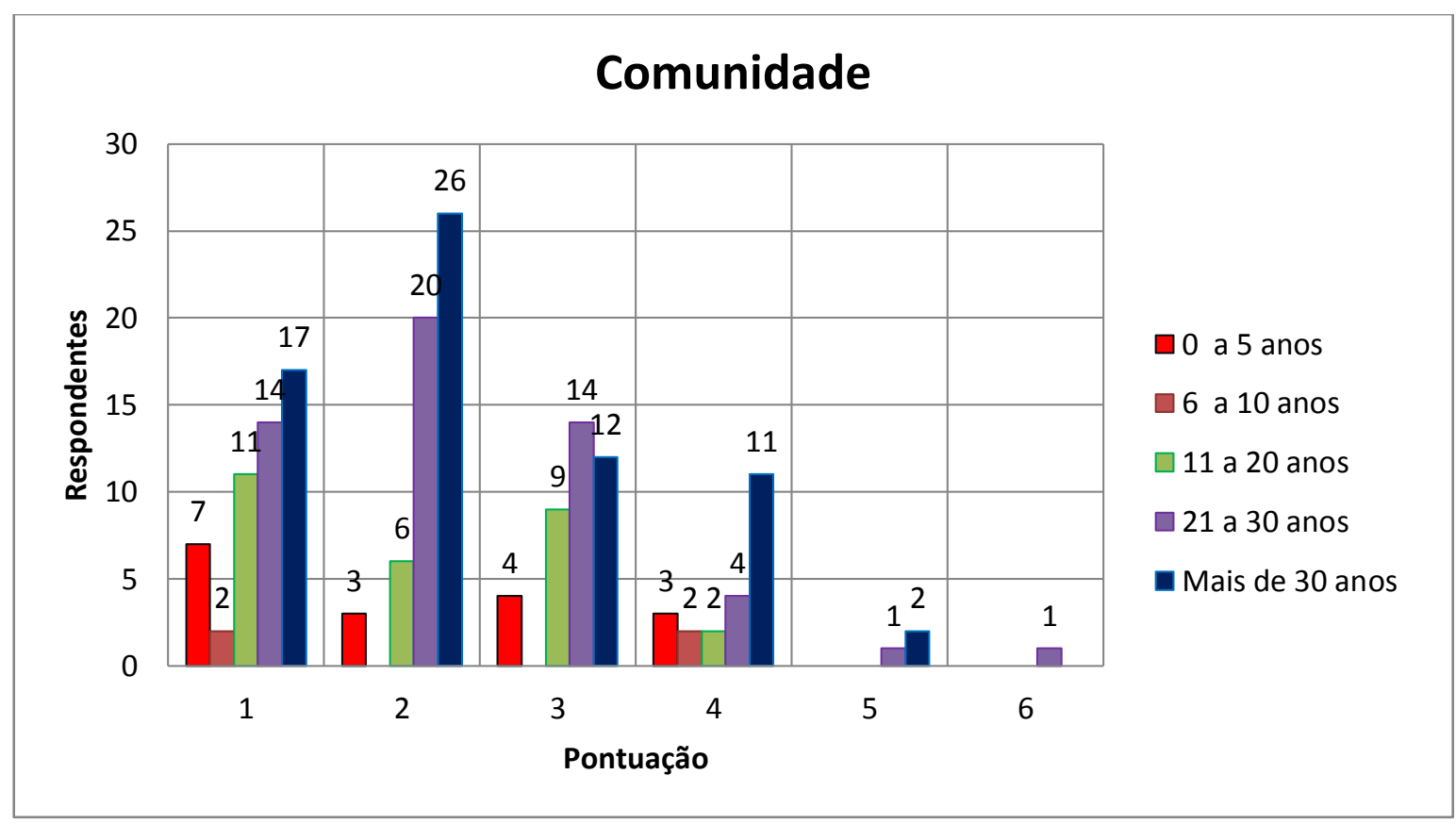

FIGURA 5.21 - Avaliação do Relacionamento do IPEN com a Comunidade do Entorno por Tempo de Trabalho na Instituição 


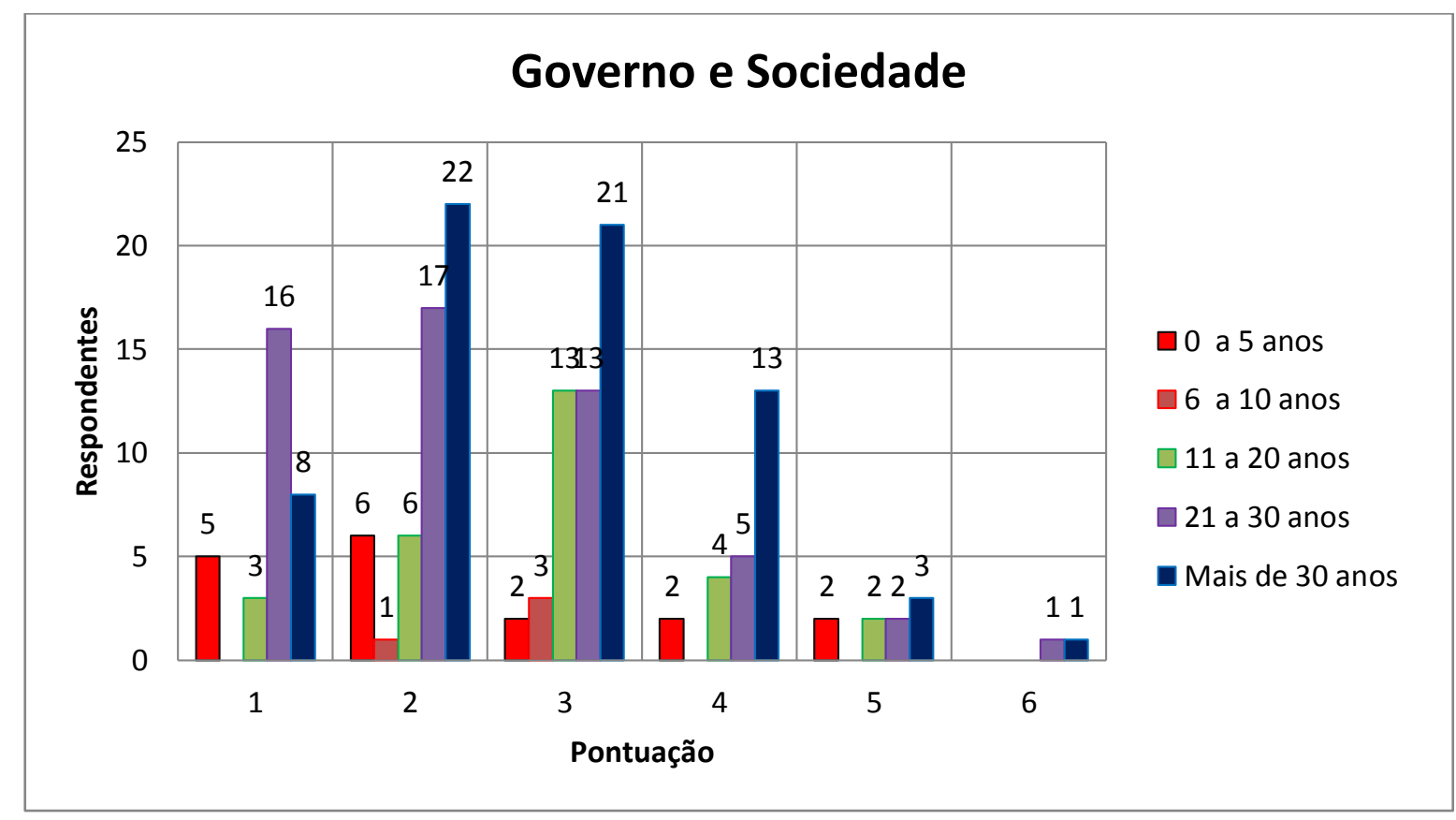

FIGURA 5.22 - Avaliação do Relacionamento do IPEN com o Governo e a Sociedade por Tempo de Trabalho na Instituição

Dependendo do tempo de instituição de cada respondente, houve uma pequena variação na avaliação da responsabilidade social do IPEN, porém a média geral foi três, igual para todos os respondentes. Observa-se que os respondentes com até 5 anos de instituição bem como os que estão entre 21 e 30 anos na instituição foram os que pior avaliaram o IPEN. Os funcionários com mais de 30 anos de instituto foram os que melhor avaliaram o IPEN.

Na TAB.5.9 a pontuação média obtida por cada dimensão da RS com base no tempo de instituição dos respondentes é apresentada.

TABELA 5.9 - Pontuação média por tempo de trabalho na Instituição

\begin{tabular}{|c|c|c|c|c|c|c|}
\hline Dimensões & $\begin{array}{l}0 \text { a } 5 \\
\text { anos }\end{array}$ & $\begin{array}{c}6 \text { a } 10 \\
\text { anos }\end{array}$ & $\begin{array}{c}11 \text { a } 20 \\
\text { anos }\end{array}$ & $\begin{array}{c}21 \text { a } 30 \\
\text { anos }\end{array}$ & $\begin{array}{l}\text { Mais } \\
\text { de } 30 \\
\text { anos }\end{array}$ & $\begin{array}{c}\text { Média } \\
\text { Total por } \\
\text { Dimensão }\end{array}$ \\
\hline Público Interno & 4 & 3 & 4 & 4 & 4 & 4 \\
\hline Cliente & 3 & 4 & 4 & 3 & 4 & 4 \\
\hline Ética & 3 & 4 & 4 & 3 & 4 & 4 \\
\hline Meio Ambiente & 3 & 3 & 3 & 3 & 4 & 3 \\
\hline Governo/Sociedade & 2 & 3 & 3 & 2 & 3 & 3 \\
\hline Comunidade & 2 & 2 & 2 & 2 & 2 & 2 \\
\hline Fornecedor & 2 & 2 & 2 & 2 & 2 & 2 \\
\hline $\begin{array}{l}\text { Média Total por } \\
\text { Tempo de } \\
\text { Instituição }\end{array}$ & 3 & 3 & 3 & 3 & 3 & 3 \\
\hline
\end{tabular}




\section{Percepção da RS do IPEN por função}

Nas FIG.5.23 até FIG.5.29 observa-se que as dimensões da RS do IPEN com base na função que os respondentes exercem no IPEN. O eixo " $x$ " representa a percepção dos respondentes com relação à RS do IPEN na escala de 1 a 6, e o eixo "y" representa a quantidade de respondentes. Cada linha/cor representa a função de cada um dos respondentes no IPEN.

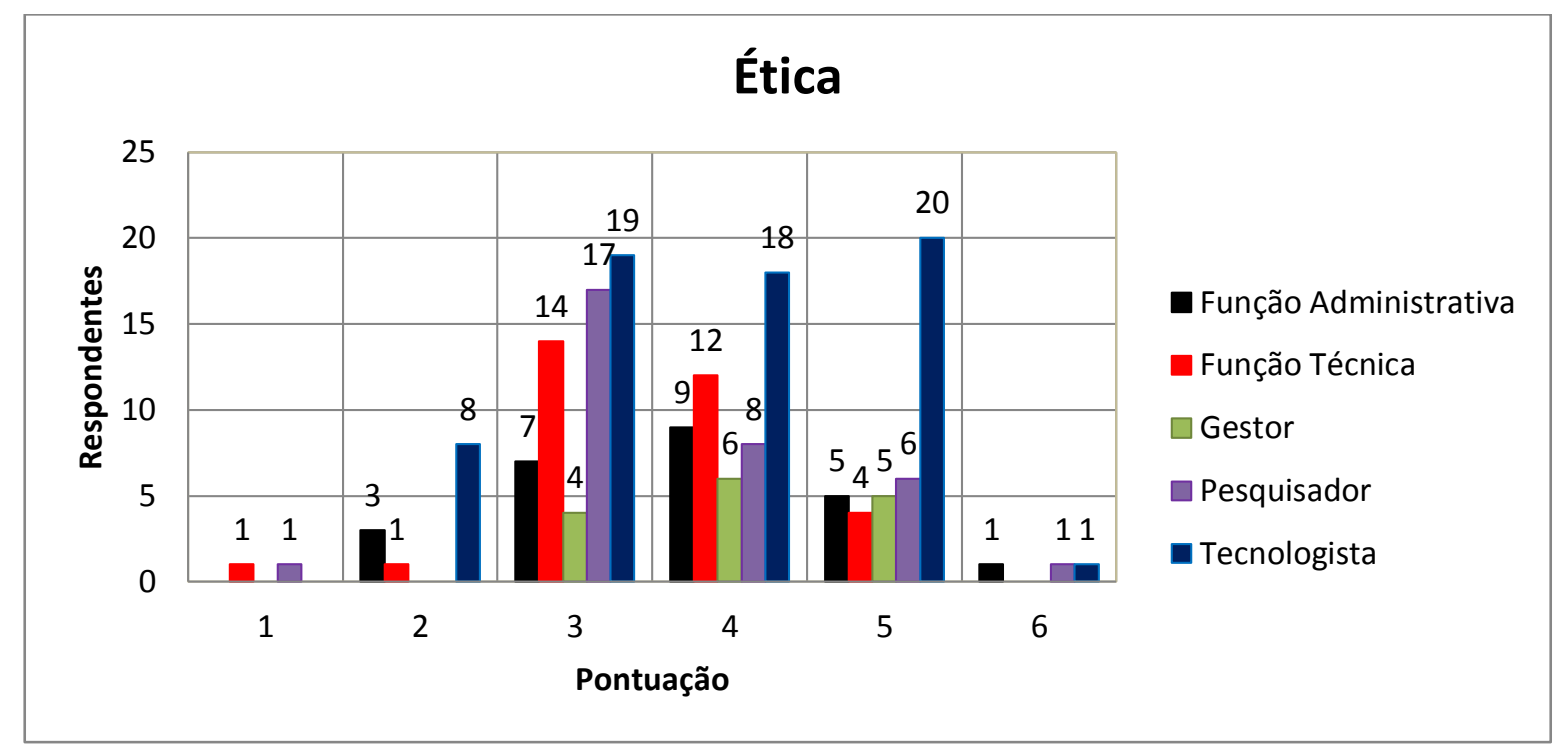

FIGURA 5.23 - Avaliação da Ética do IPEN por Função

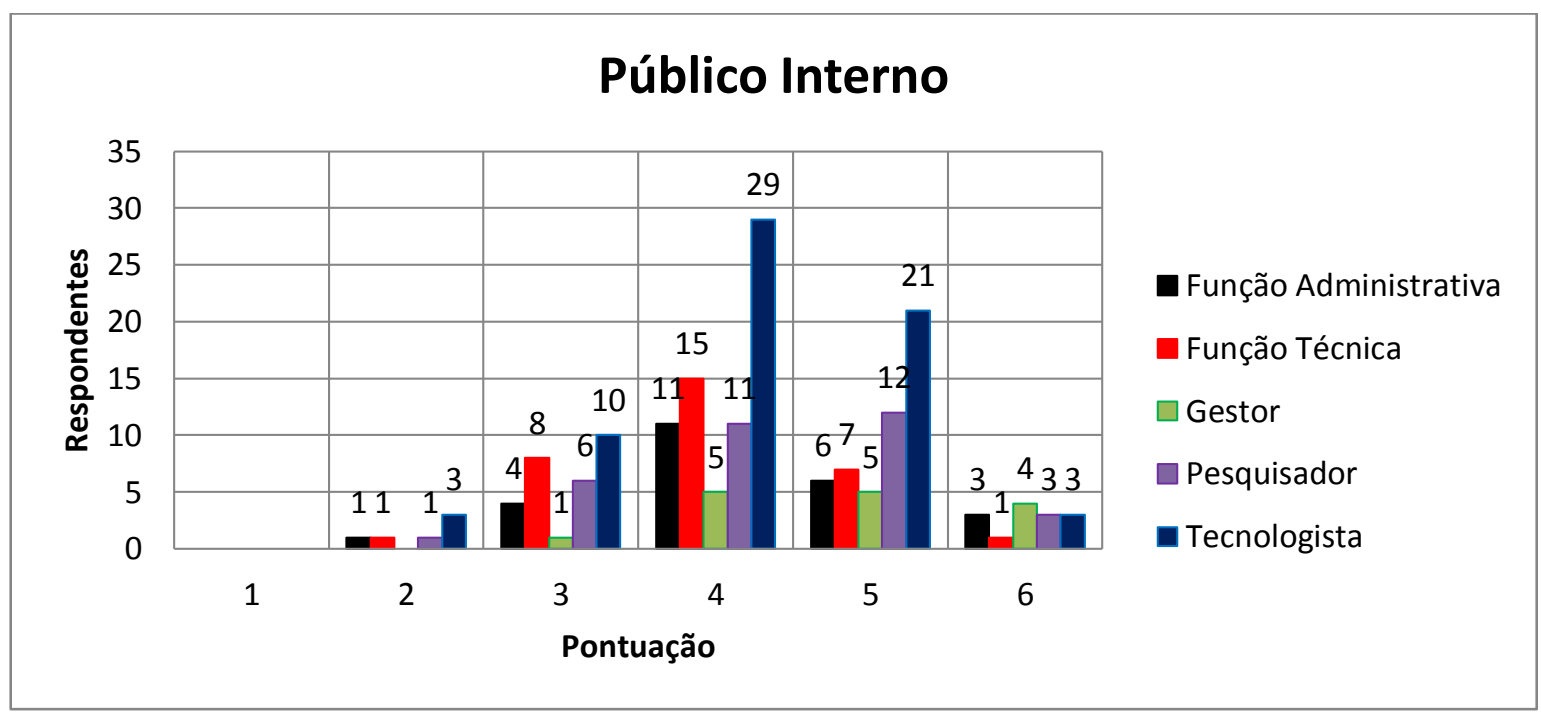

FIGURA 5.24 - Avaliação RS do IPEN ára com o Público Interno por Função 


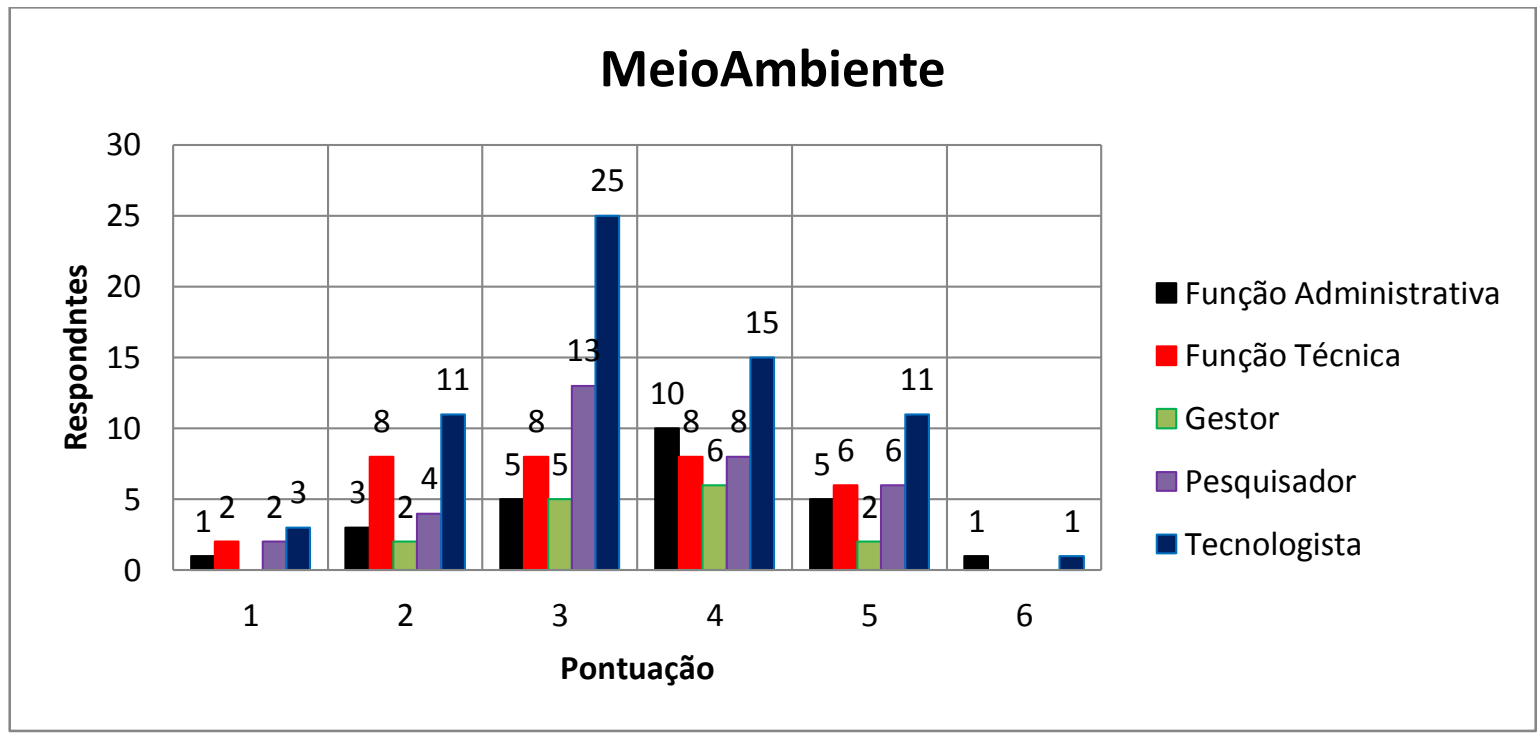

FIGURA 5.25 - Avaliação do Tratamento Dado ao Meio Ambiente pelo IPEN por Função

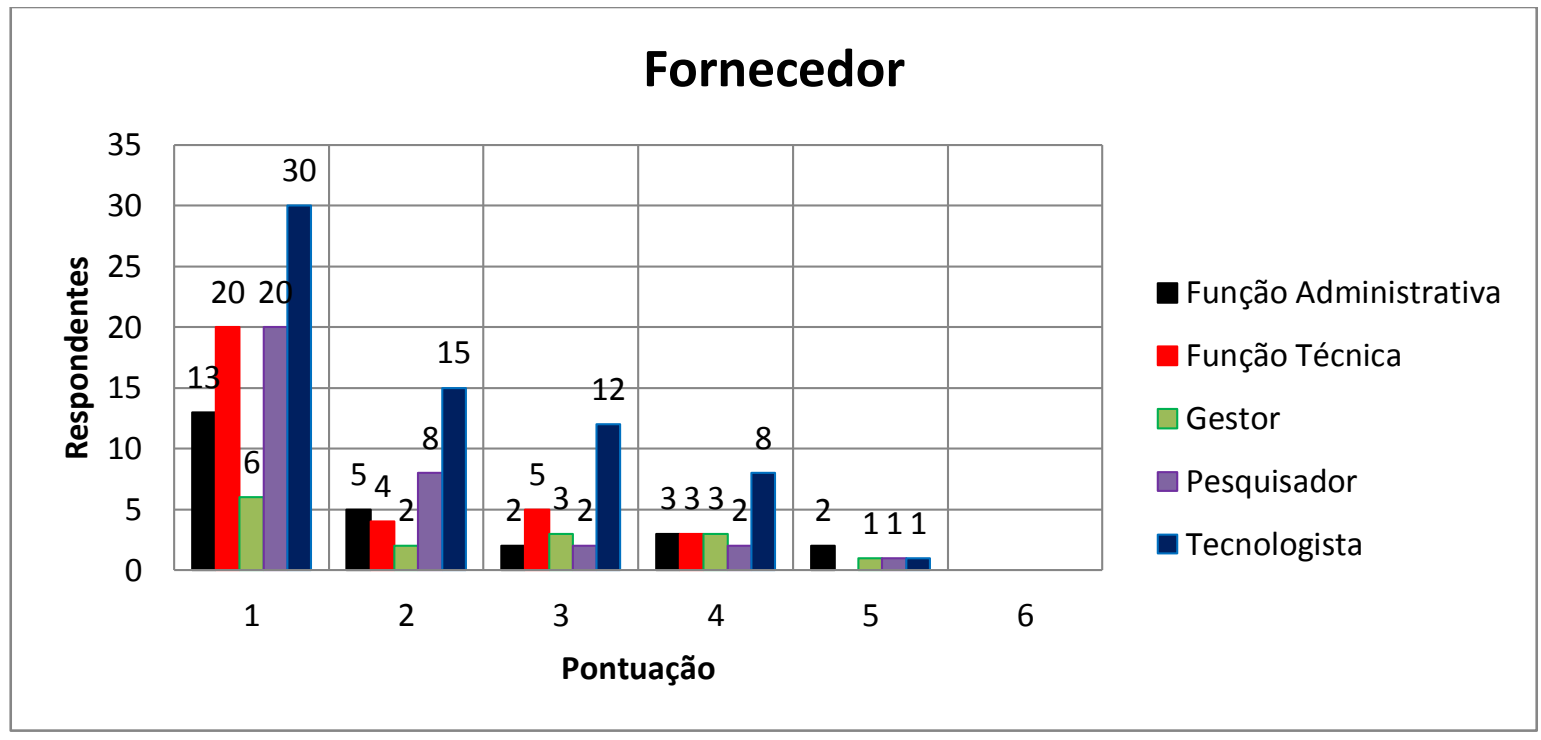

FIGURA 5.26 - Avaliação do Relacionamento do IPEN com os Fornecedores por Função 


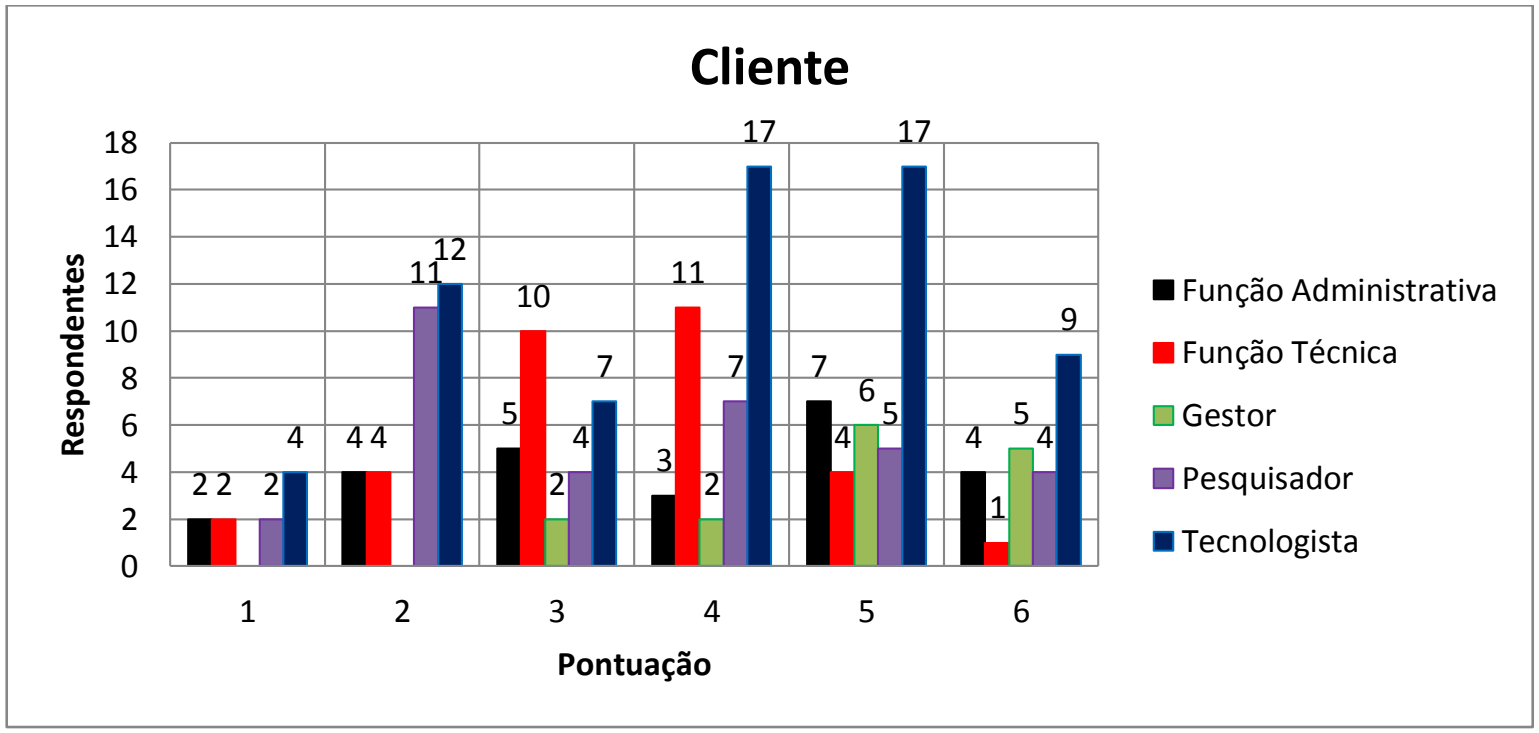

FIGURA 5.27- Avaliação do Relacionamento do IPEN com os seus Clientes por Função

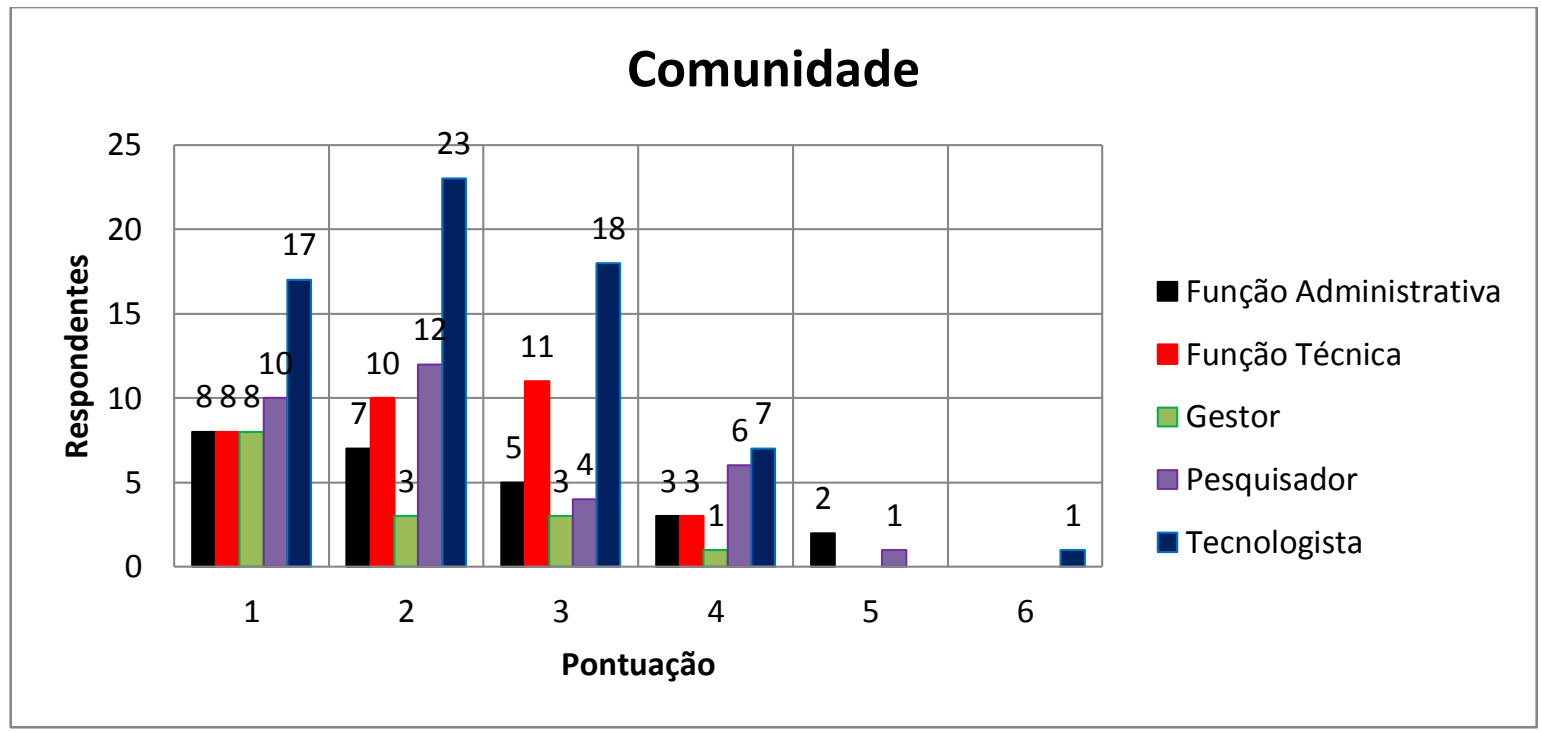

FIGURA 5.28- Avaliação do Relacionamento do IPEN com a Comunidade em Torno por Função 


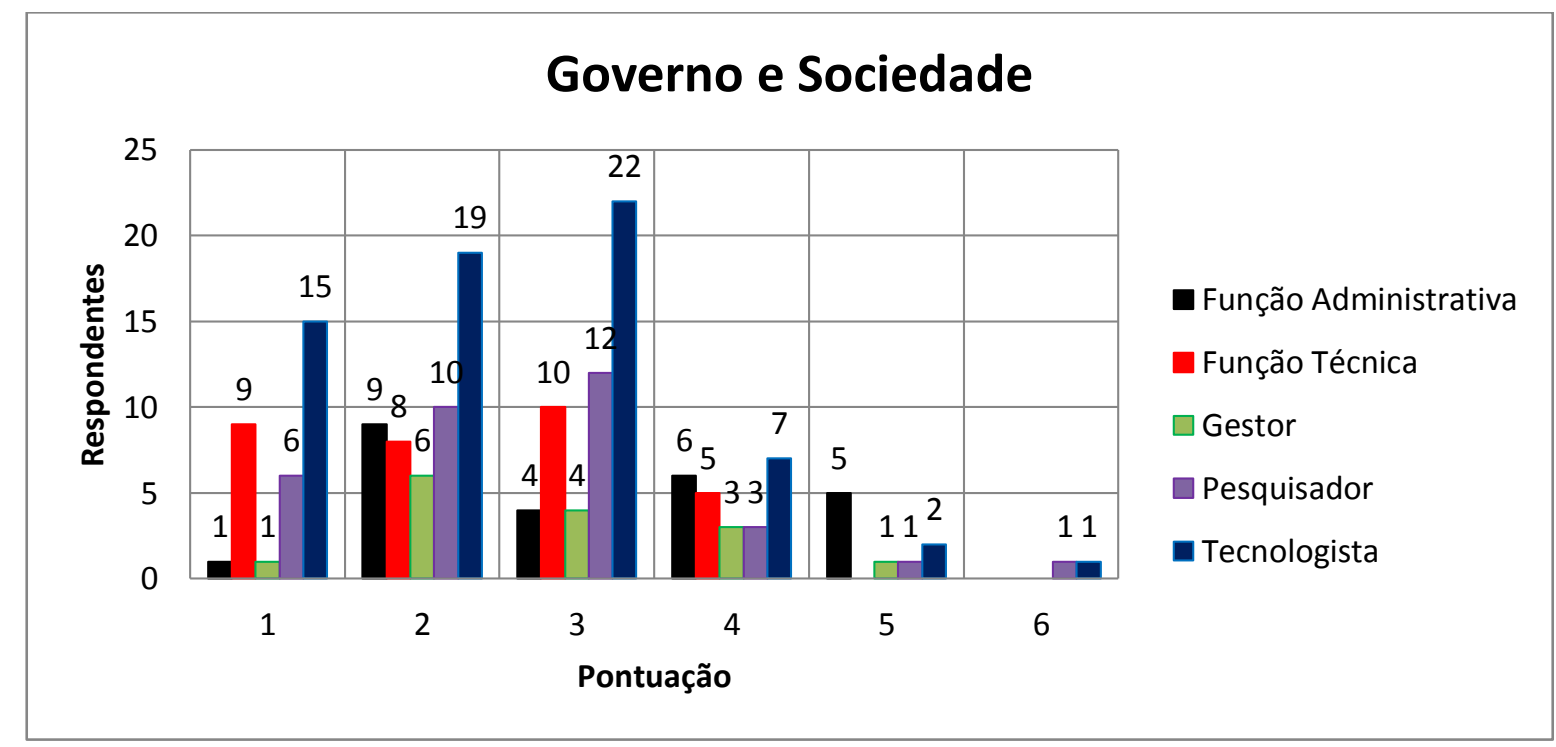

FIGURA 5.29- Avaliação do Relacionamento do IPEN com o Governo e a Sociedade por Função

Observa-se que a percepção da amostra com relação às dimensões da RS do IPEN segue certo padrão de pontuação. Existe uma pequena variação dependendo da função que o respondente exerce no IPEN. Os respondentes que melhor avaliaram o IPEN foram os gestores e os funcionários da área administrativa. Os respondentes com função técnica foram os que pior avaliaram o IPEN. Na média geral de todas as funções, os respondentes avaliaram o IPEN com média equivalente a três. As dimensões: público interno, cliente e ética obtiveram média quatro. As dimensões: meio ambiente e governo/sociedade obtiveram média três e as dimensões comunidade e fornecedores obtiveram média dois. Na TAB.5.10 é demonstrada a pontuação média obtida por cada dimensão da RS com base na função dos respondentes. 
TABELA 5.10 - Pontuação média por função

\begin{tabular}{lcccccc} 
Dimensões & Gestor & Pesquisador & Tecnologista & $\begin{array}{c}\text { Função } \\
\text { Técnica }\end{array}$ & $\begin{array}{c}\text { Função } \\
\text { Administrativa }\end{array}$ & $\begin{array}{c}\text { Média } \\
\text { Total por } \\
\text { Dimensão }\end{array}$ \\
\hline Público Interno & 5 & 4 & 4 & 4 & 4 & 4 \\
Cliente & 5 & 3 & 4 & 3 & 4 & 4 \\
Ética & 4 & 4 & 4 & 3 & 4 & 4 \\
Meio Ambiente & 3 & 3 & 3 & 3 & 4 & 3 \\
Governo/Sociedade & 3 & 2 & 2 & 2 & 3 & 3 \\
Comunidade & 2 & 2 & 2 & 2 & 2 & 2 \\
Fornecedor & 2 & 2 & 2 & 2 & 2 & 2 \\
\hline$\quad$ Média Total por & $\mathbf{3}$ & $\mathbf{3}$ & $\mathbf{3}$ & $\mathbf{3}$ & $\mathbf{3}$ & $\mathbf{3}$ \\
\hline Função & & & & & &
\end{tabular}

\section{Percepção da RS do IPEN por grau de instrução}

Nas FIG.5.30 até FIG.5.36 as análises das dimensões da RS do IPEN com base no grau de instrução dos respondentes estão apresentadas. O eixo " $x$ " representa a percepção dos respondentes com relação à RS do IPEN na escala de 1 a 6 , e o eixo "y" representa a quantidade de respondentes. Cada linha/cor representa o grau de instrução de cada um dos respondentes no IPEN.

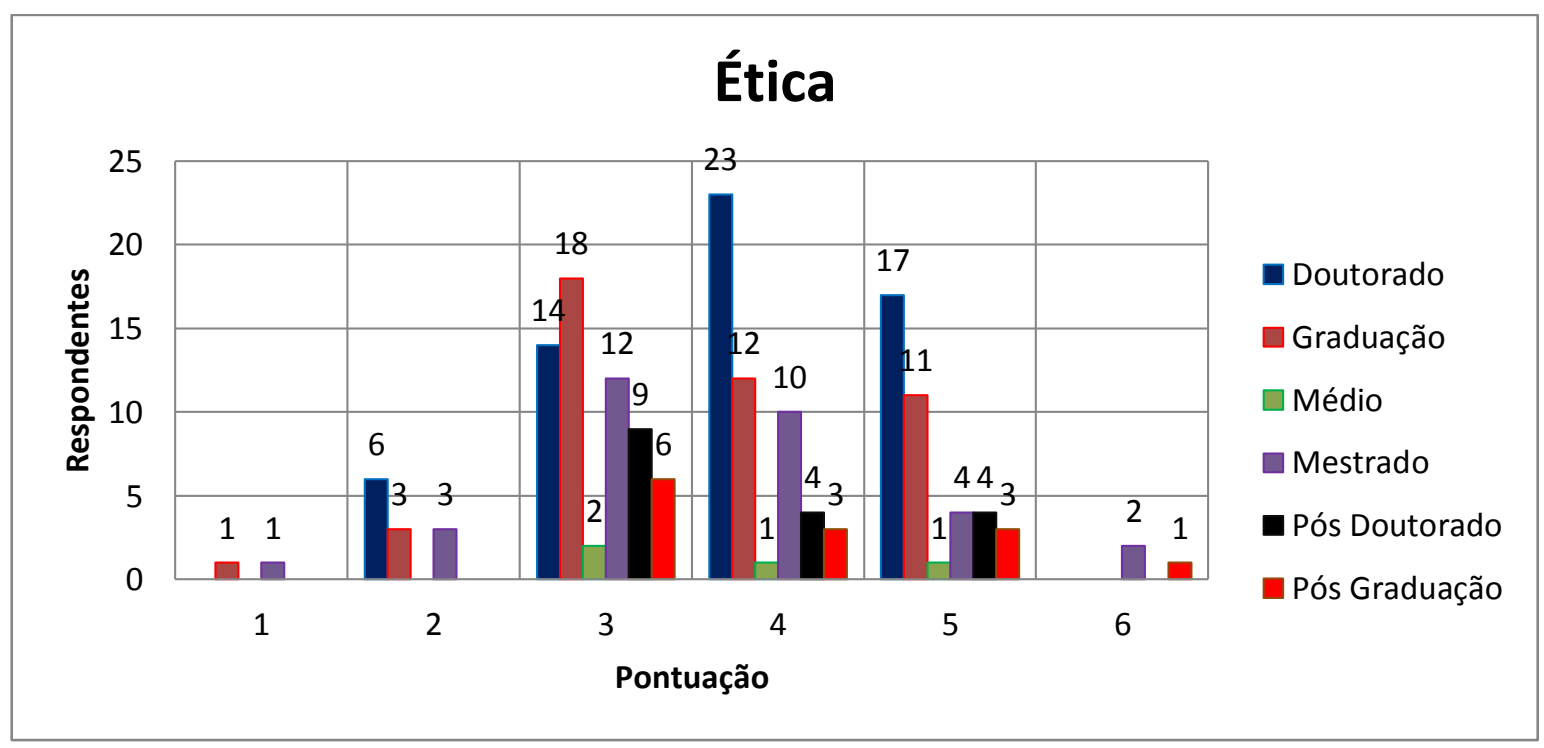

FIGURA 5.30 - Avaliação da Ética do IPEN por Grau de Instrução 


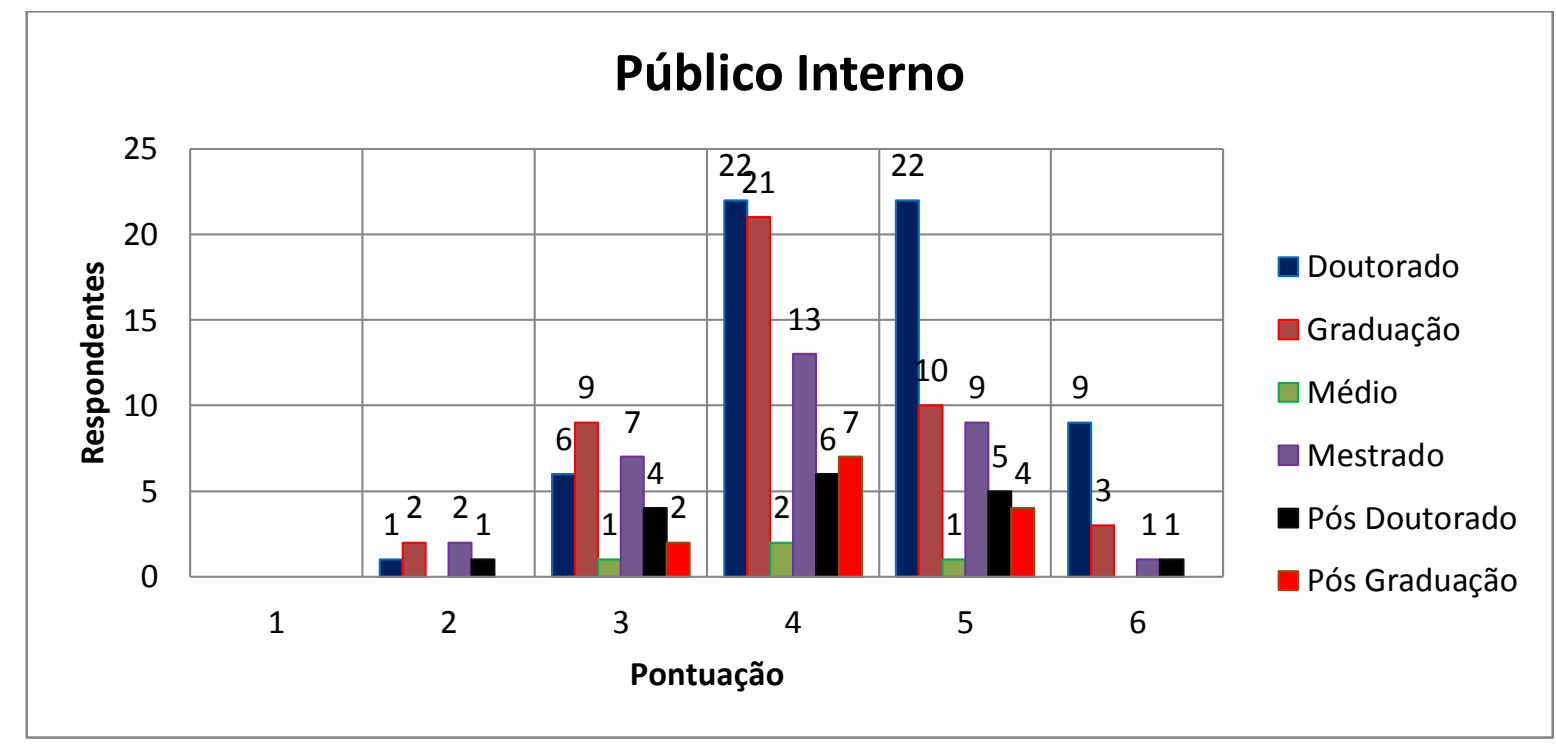

FIGURA 5.31- Avaliação RS do IPEN para com o Público Interno por Grau de Instrução

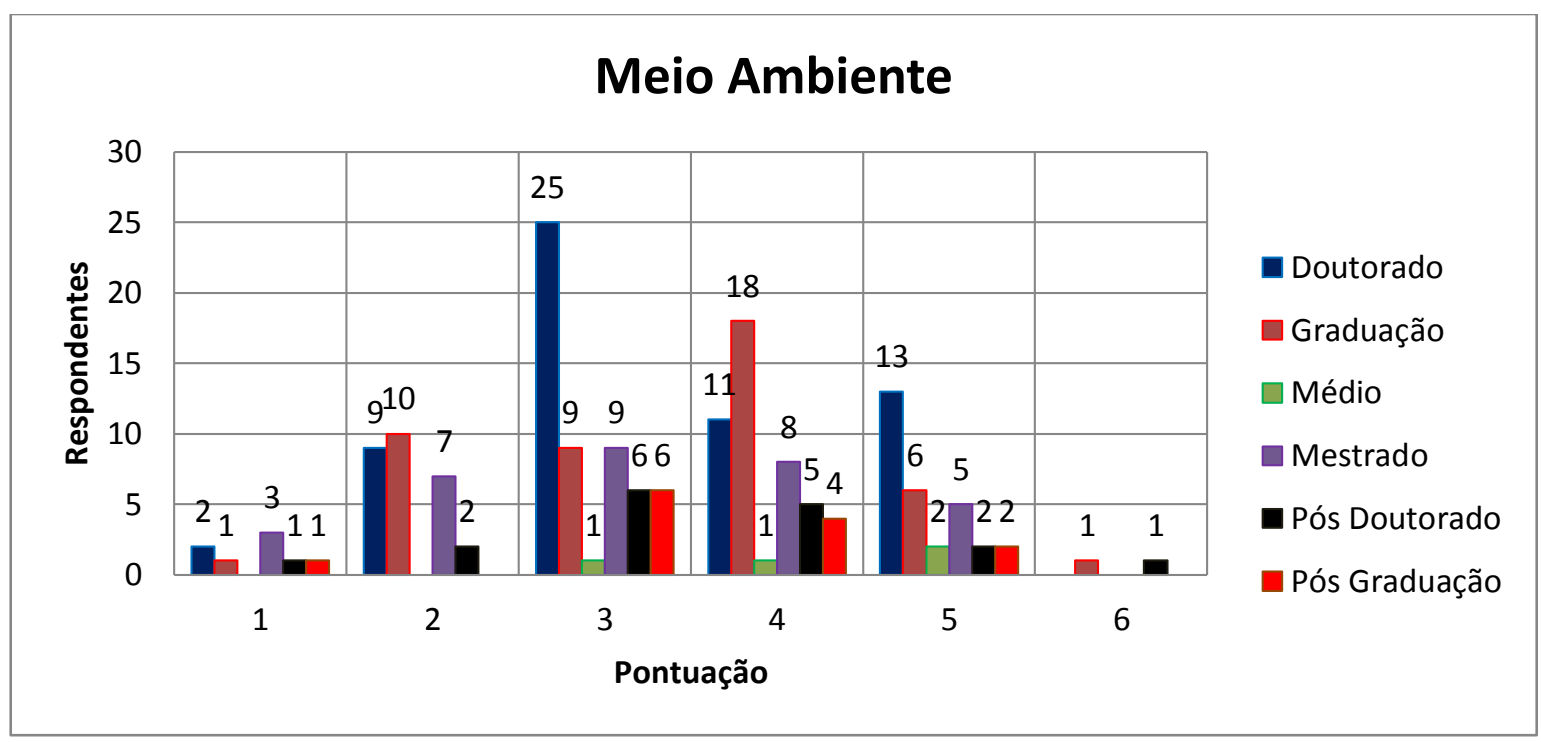

FIGURA 5.32- Avaliação do Tratamento Dado ao Meio Ambiente pelo IPEN por Grau de Instrução 


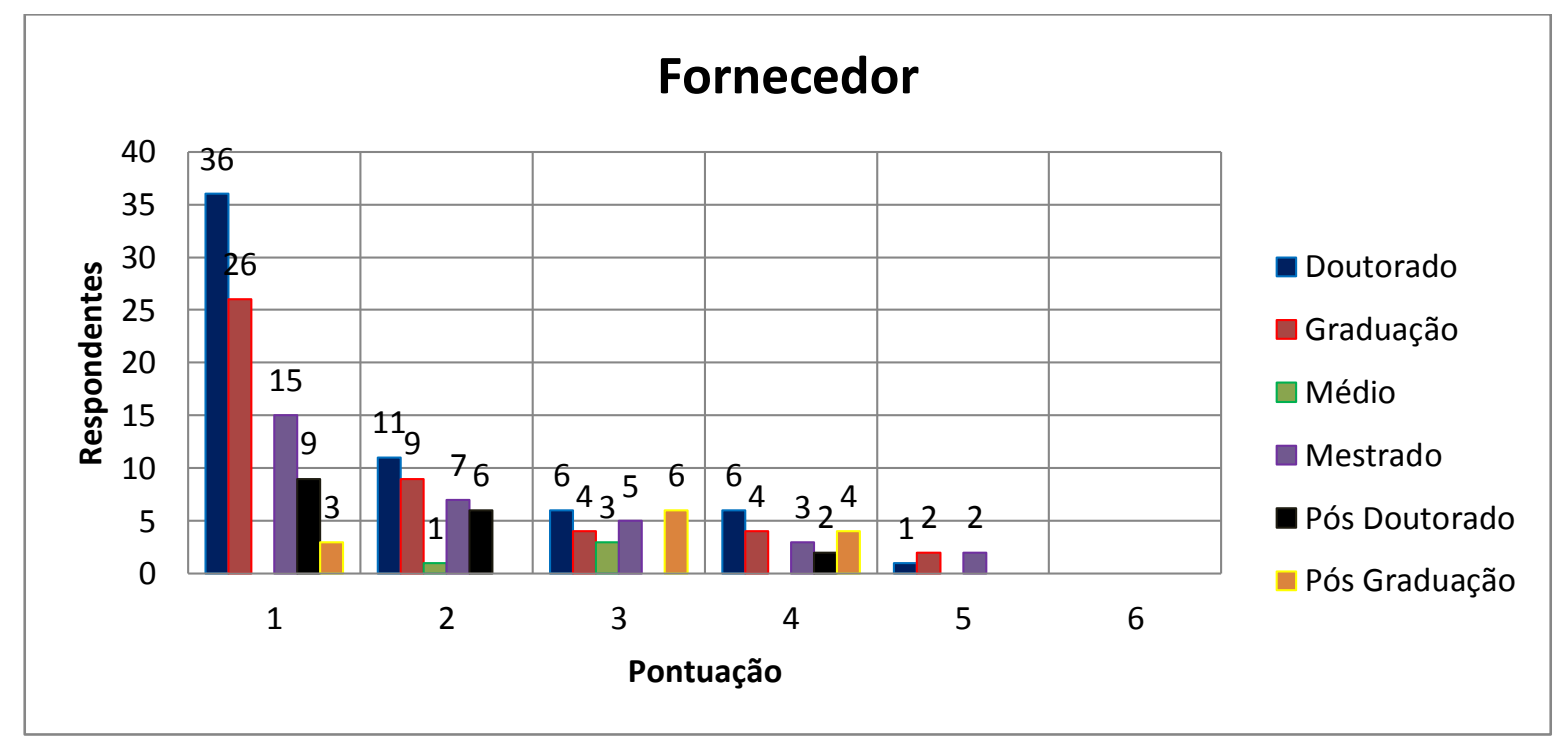

FIGURA 5.33 - Avaliação do Relacionamento do IPEN com os Fornecedores por Grau de Instrução

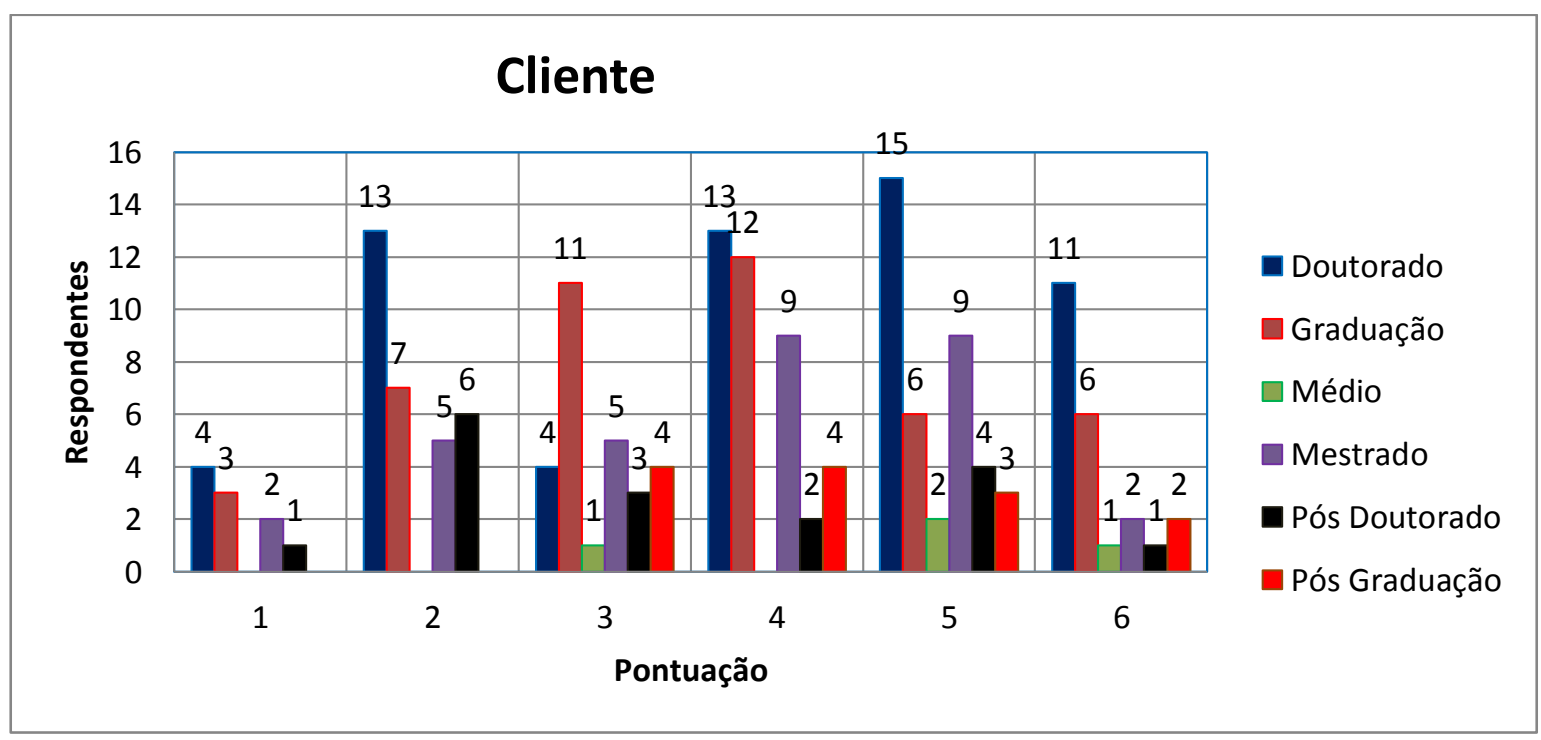

FIGURA 5.34- Avaliação do Relacionamento do IPEN com os seus Clientes por Grau de Instrução 


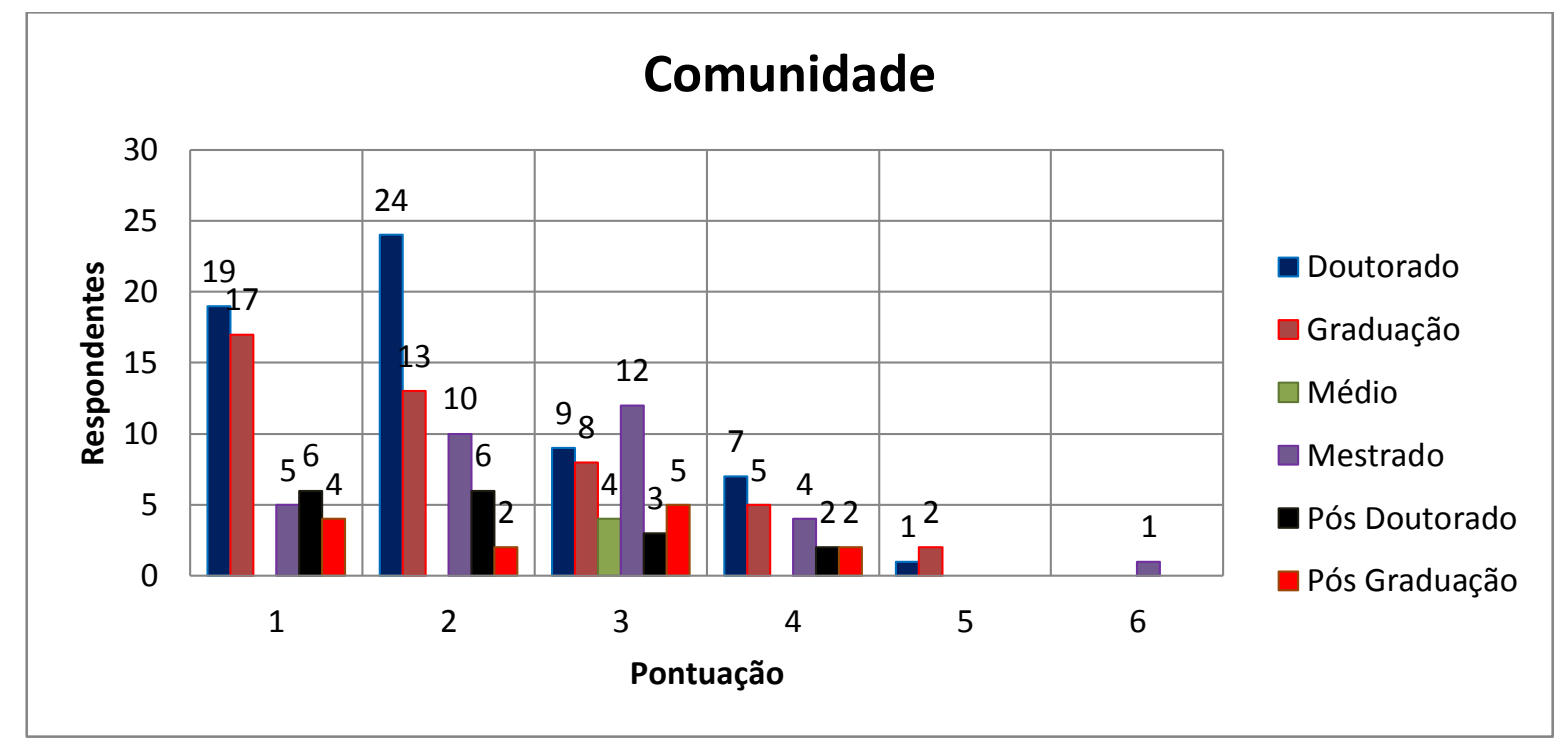

FIGURA 5.35- Avaliação do Relacionamento do IPEN com a Comunidade do Entorno por Grau de Instrução

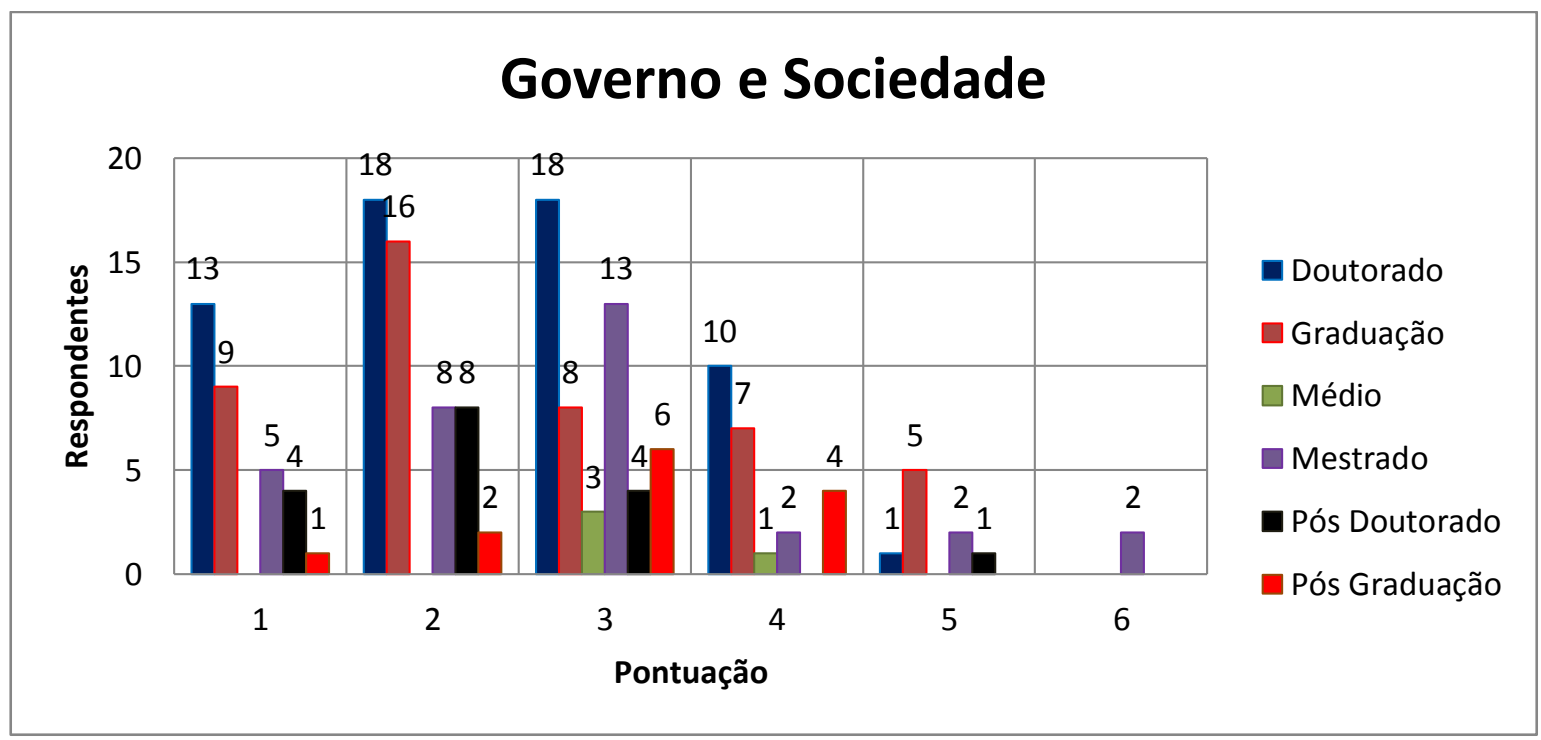

FIGURA 5.36- Avaliação do Relacionamento do IPEN com o Governo e a Sociedade por Grau de Instrução

Com relação ao grau de instrução dos respondentes, observa-se que a percepção com relação às dimensões da RS do IPEN segue certo padrão de pontuação, com uma pequena variação. Os respondentes que melhor avaliaram o IPEN foram aqueles com nível médio. Os respondentes com doutorado e pós- 
doutorado foram os que pior avaliaram o IPEN. Na média geral, todos avaliaram o IPEN com média equivalente a três, exceto os funcionários de nível médio que avaliaram com média quatro. As dimensões: público interno, cliente e ética obtiveram média quatro. As dimensões: meio ambiente e governo/sociedade obtiveram média três e as dimensões comunidade e fornecedores obtiveram média dois. Na TAB.5.11 a pontuação média obtida por cada dimensão da RS com base no grau de instrução dos respondentes é apresentada.

TABELA 5.11 - Pontuação média por grau de instrução

\begin{tabular}{|c|c|c|c|c|c|c|}
\hline Dimensões & $\begin{array}{c}\text { Pós- } \\
\text { doutorado }\end{array}$ & Doutorado & Mestrado & $\begin{array}{l}\text { Pós- } \\
\text { graduação }\end{array}$ & Médio & $\begin{array}{c}\text { Média } \\
\text { Total por } \\
\text { Dimensão }\end{array}$ \\
\hline Público Interno & 4 & 4 & 4 & 4 & 4 & 4 \\
\hline Cliente & 3 & 4 & 4 & 4 & 5 & 4 \\
\hline Ética & 4 & 4 & 4 & 4 & 4 & 4 \\
\hline Meio Ambiente & 3 & 3 & 3 & 3 & 4 & 3 \\
\hline Governo/Sociedade & 2 & 2 & 3 & 3 & 3 & 3 \\
\hline Comunidade & 2 & 2 & 3 & 2 & 3 & 2 \\
\hline Fornecedor & 2 & 2 & 2 & 3 & 3 & 2 \\
\hline $\begin{array}{c}\text { Média Total por } \\
\text { Grau de } \\
\text { Escolaridade }\end{array}$ & 3 & 3 & 3 & 3 & 4 & 3 \\
\hline
\end{tabular}

\section{Percepção da RS do IPEN por Centro de Pesquisa}

$\mathrm{Na}$ análise das dimensões da RS do IPEN com base no Centro de Pesquisa em que trabalham os respondentes, observa-se que a percepção da amostra com relação às dimensões da RS do IPEN segue o mesmo comportamento. Existe uma pequena variação dependendo do Centro de Pesquisa em que o respondente está alocado. Os respondentes do Centro de Ciência e Tecnologia de Materiais (CCTM) foram os que pior avaliaram o IPEN. Os demais Centros avaliaram o IPEN com média três. Na média geral, as dimensões público interno, ética e cliente obtiveram média quatro; meio ambiente, média três e as dimensões fornecedores, governo/sociedade e comunidade obtiveram média dois. 
Na TAB.5.12 e na FIG.5.37 podem ser observadas as pontuações médias obtidas por cada dimensão da RS com base nos Centros de Pesquisa onde os respondentes estão alocados.

TABELA 5.12 - Pontuação média por Centro de Pesquisa

\begin{tabular}{|c|c|c|c|c|c|c|c|c|c|c|c|c|c|}
\hline Dimensões & m & $\begin{array}{l}\text { T } \\
\text { ల }\end{array}$ & Zত & $\underset{\mathrm{J}}{\mathrm{E}}$ & प্ & 岕 & $\frac{\Phi}{J}$ & 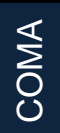 & 孚 & $\frac{\sigma}{\frac{\sigma}{\sigma}}$ & $\frac{\mathfrak{r}}{\mathfrak{b}}$ & $\stackrel{\text { 온 }}{\stackrel{5}{3}}$ & $\begin{array}{l}\text { Média Total } \\
\text { por } \\
\text { Dimensão }\end{array}$ \\
\hline Público Interno & 4 & 4 & 4 & 4 & 4 & 4 & 4 & 4 & 4 & 4 & 4 & 4 & 4 \\
\hline Cliente & 3 & 4 & 3 & 3 & 4 & 4 & 2 & 4 & 5 & 4 & 4 & 4 & 4 \\
\hline Ética & 4 & 4 & 3 & 3 & 3 & 4 & 4 & 4 & 4 & 4 & 3 & 4 & 4 \\
\hline Meio Ambiente & 3 & 3 & 3 & 2 & 3 & 3 & 3 & 4 & 4 & 4 & 4 & 3 & 3 \\
\hline Governo/Sociedade & 2 & 2 & 2 & 2 & 3 & 2 & 3 & 2 & 2 & 3 & 3 & 3 & 2 \\
\hline Comunidade & 3 & 2 & 2 & 2 & 2 & 3 & 2 & 2 & 2 & 2 & 2 & 2 & 2 \\
\hline Fornecedor & 2 & 2 & 2 & 2 & 2 & 2 & 2 & 2 & 2 & 2 & 2 & 2 & 2 \\
\hline $\begin{array}{l}\text { Média Total por } \\
\text { Centro }\end{array}$ & 3 & 3 & 3 & 2 & 3 & 3 & 3 & 3 & 3 & 3 & 3 & 3 & 3 \\
\hline
\end{tabular}

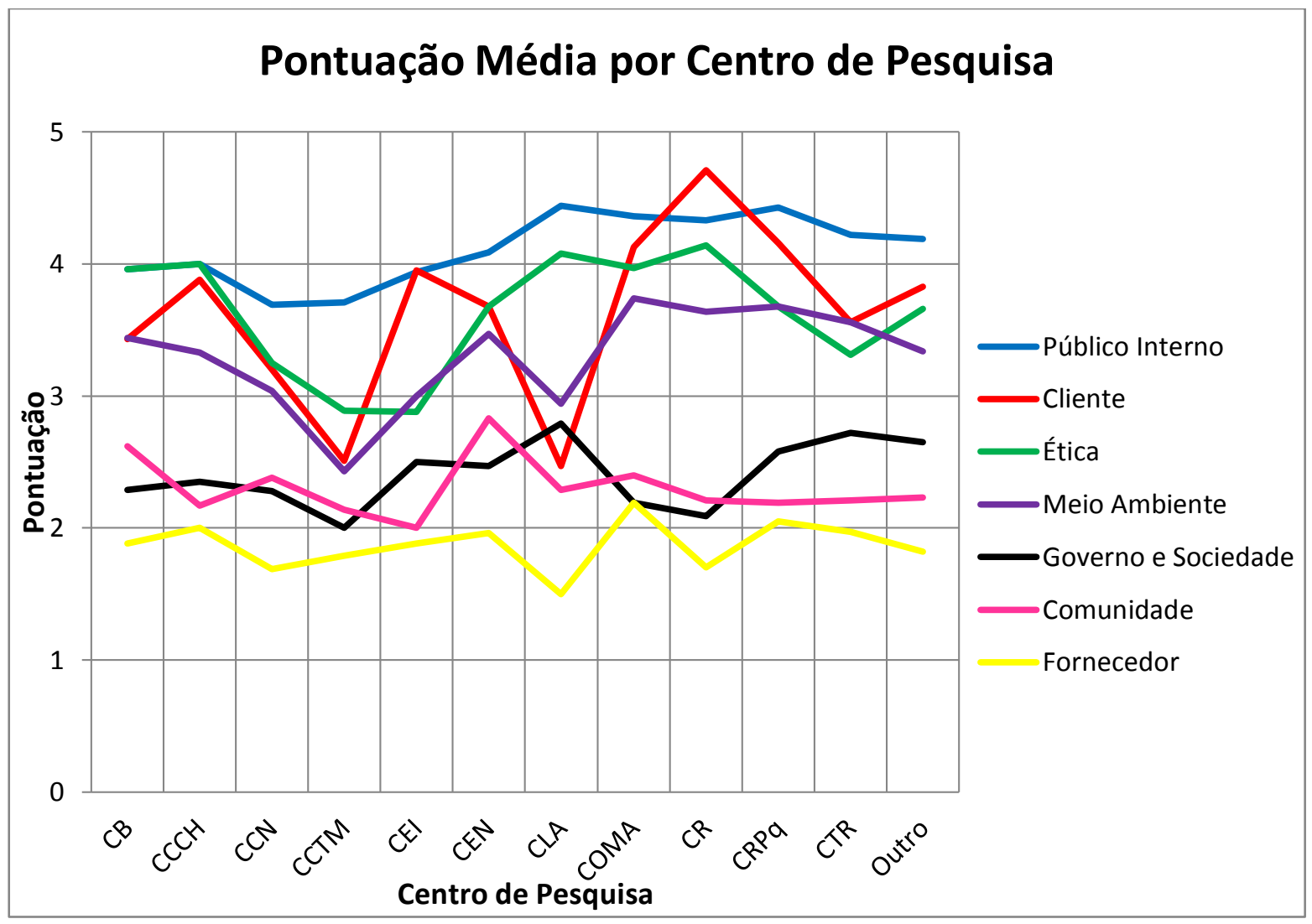

FIGURA 5.37 - Pontuação Média por Centro de Pesquisa 
Observa-se que o centro de pesquisa que pior avaliou o IPEN foi o CCTM e os que melhor avaliaram o IPEN foram os CR e CRPq. Fazendo uma analogia com a quantidade de respondentes por centro, constata-se que o CCTM tem apenas 7 respondentes ( $4 \%$ do total), o CR tem 11 respondentes (6\% do total) e o CRPq tem 23 respondentes (13\% do total).

\section{Percepção da RS do IPEN - geral}

Independentemente da segmentação feita nos respondentes, existe um padrão de avaliação das dimensões da RS do IPEN. Essa avaliação é apresentada na FIG.5.38.

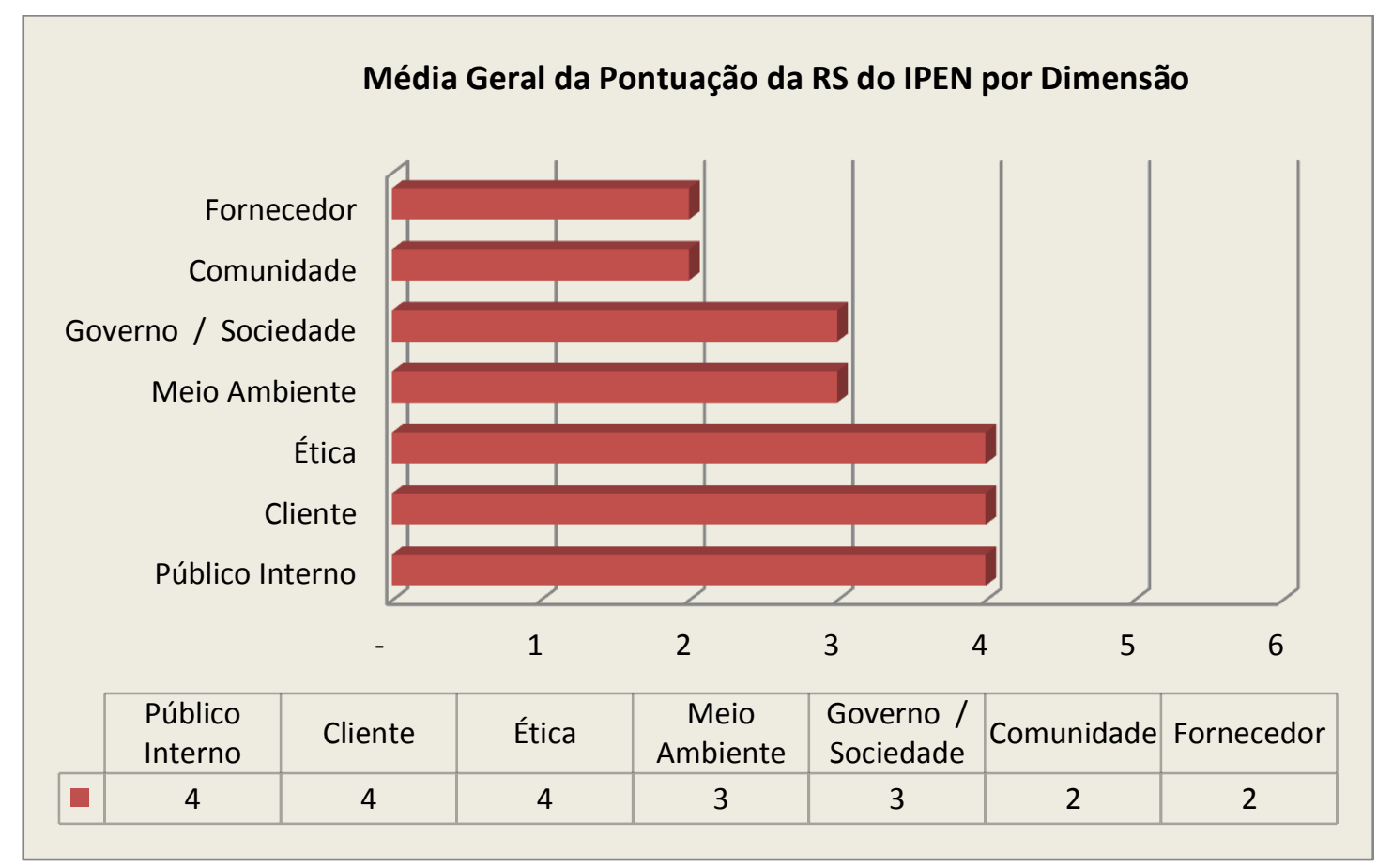

FIGURA 5.38- Avaliação Geral da RS IPEN Independentemente do Perfil dos Respondentes 


\subsubsection{Análise descritiva da escala}

Os constructos que compõem as Dimensões da RS foram medidos por meio de uma escala, cujas medidas descritivas serão apresentadas a seguir. Para cada variável está relacionada sua respectiva média, desvio-padrão, coeficiente de variabilidade, bem como suas medidas de assimetria, curtose e os percentuais das respostas para cada nível da escala de seis pontos. Os resultados abaixo descritos foram calculados utilizando o software MS-Excel e o software estatístico Statistical Package for Social Sciences (SPSS).

A normalidade de todas as variáveis foi analisada mediante 0 teste de Kolmogorov-Smirnov. Nesse teste, se uma variável possui distribuição normal, a significância deve estar acima de 0,05 e, no caso da pesquisa realizada no IPEN, todas as variáveis tiveram significância igual a zero, ou seja, não possuem distribuição normal.

As medidas de assimetria (skewness) e curtose (kurtosis) também são utilizadas para analisar a normalidade das variáveis. Os valores devem ser próximos de zero para indicar normalidade.

Calculou-se a assimetria e a curtose de todas as variáveis envolvidas na pesquisa. Todas possuem valores significativamente distantes de zero, portanto, por meio desta análise, verifica-se que todas as variáveis não apresentam distribuição normal.

Na TAB.5.13 as variáveis pertencentes às sete dimensões da RS são apresentadas. A escala mede a concordância/conhecimento atribuída para cada item, variando de 1 (total discordância/desconhecimento) até 6 (total concordância /conhecimento).

O constructo melhor avaliado foi público interno, no qual cinco dos oito itens avaliados obtiveram médias acima de quatro. Destacam-se positivamente os itens B8 (valorização da diversidade e promoção da equidade) e B10 (relacionamento com o sindicato), que obtiveram médias 5,22 e 5,06, respectivamente. Em contrapartida, o item B6 (benefícios adicionais) obteve a pontuação 2,64, que foi a pontuação mais baixa do constructo. Os demais itens avaliados B5 (cuidados com a saúde segurança e condições de trabalho); B7 (critérios de contratação); B9 (inclusão de pessoas com deficiência); B11 (compromisso com o desenvolvimento profissional e empregabilidade) e B12 (acesso à informação) obtiveram média entre três e quatro pontos. 
O constructo cliente foi o segundo melhor avaliado. O item E23 (Politica de comunicação empresarial) foi o melhor avaliado, com média igual a 4,25. Os demais itens E20 (excelência de atendimento); E21 (dúvidas e sugestões); E22 (satisfação dos consumidores / clientes) e E24 (conhecimento e gerenciamento dos danos potenciais dos produtos e serviços) obtiveram médias entre três e quatro pontos.

O terceiro constructo melhor avaliado foi a ética. O item A2 - (Balanço Social) com pontuação média igual a 1,64 baixou a média do constructo levandoo para o terceiro lugar. Os demais itens foram bem avaliados: A1 (compromissos éticos), com 3,98; A3 (governança corporativa), com 3,94 e A4 (garantida da qualidade), com 4,82 pontos.

Em quarto lugar está o constructo meio ambiente. O item de maior destaque, ou seja, o item melhor pontuado foi C13 (gerenciamento dos impactos sobre o meio ambiente e do ciclo de vida de produtos e serviços), com média igual a 4,26. O item pior pontuado foi o C15 (educação e conscientização ambiental), com média igual a 2,53. O item C14 (comprometimento do instituto com a melhoria da qualidade ambiental) obteve média igual a 3,37.

Em quinto lugar está o constructo comunidade. Os itens piores avaliados, com pontuação média abaixo de dois, foram os itens F28 (envolvimento da empresa em ação social) e F29 (relações com entidades beneficiárias). Os demais itens F25 (gerenciamento do impacto da empresa na comunidade do entorno); F26 (relacionamento com a comunidade do entorno); F27 (estímulo ao trabalho voluntário); F30 (participação comunitária) e F31 (benefícios para o negócio) obtiveram média entre dois e três pontos.

O constructo governo/sociedade ficou em sexto lugar. Os itens piores avaliados foram G34 (participação e acompanhamento das administrações públicas) e G35 (melhorias nos espaços públicos e apoio a iniciativas sociais governamentais), com média abaixo de dois. O item G31 (participação e influência sindical) ficou com média igual a 2,86, e o item G33 (envolvimento em campanhas políticas) ficou com média de 3,43.

O constructo pior avaliado foi fornecedor. Nesse constructo, todos os itens obtiveram uma média abaixo de dois pontos: D16 (Critérios de seleção e avaliação dos fornecedores), com 1,95 pontos; D17 (empregados dos fornecedores), com 1,91 pontos; D18 (responsabilidade social dos fornecedores), 
com 1,88 pontos e D19 (apoio ao desenvolvimento dos fornecedores), com 1,79 pontos.

Em resumo, os constructos melhores avaliados foram público interno, clientes e ética. Os constructos medianamente avaliados foram meio ambiente $\mathrm{e}$ governo/sociedade, e os constructos piores avaliados foram comunidade e fornecedores. 
TABELA 5.13 Medidas Descritivas - Escalas da Responsabilidade Social do IPEN

TABELA 27 - Medidas Descritivas - Escalas da RS do IPEN

ARIÁVEIS

$\operatorname{ESCALA}(\%)$

DESVIO- COEFIC. D

ASSIMETRIA CURTOSE

A1 Compromissos éticos

A2 Balanço social

A3 Governança corporativa

Público Interno

B5 Cuidados com saúde segurança e condições de trabalho

B7 Critérios de contratação

B8 Valorização da diversidade e promoção da equidade

B9 Inclusão de pessoas com deficiência

B9 Inclusão de pessoas com

B11 Compromisso com o desenvolvimento profissional e empregabilidade

B12 Acesso à informação

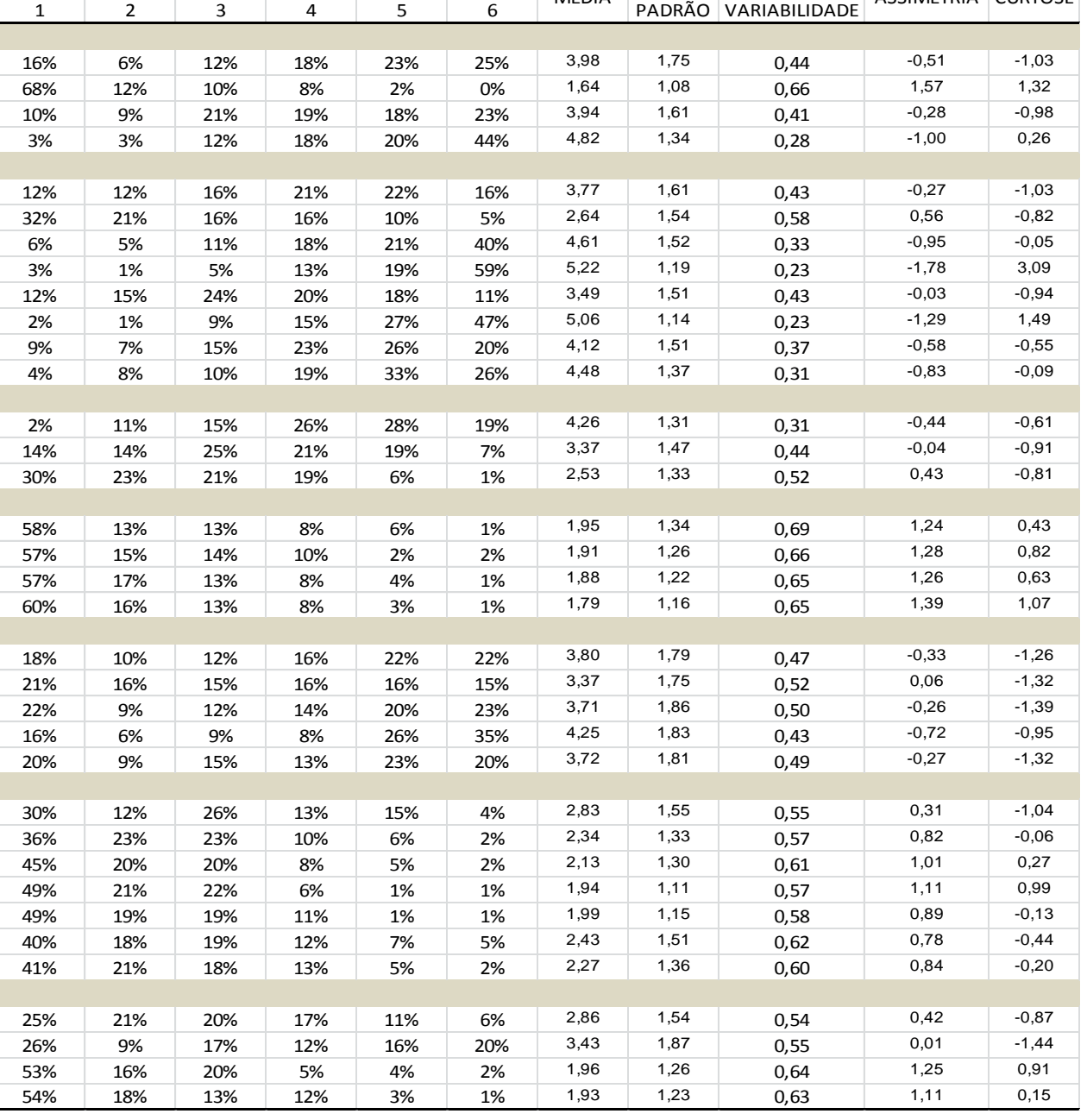

C13 Gerenciamento dos impactos sobre o meio ambiente e do ciclo de vida de produtos e serviços

C14 Comprometimento do instituto com a melhoria da qualidade ambiental

C15 Educação e conscientizaçăo ambiental

D16 Critérios de seleção e avaliação dos fornecedores

D18 Responsabilidade social dos fornecedores

D19 Apoio ao desenvolvimento dos fornecedores

Clientes

E20 Excelência de atendimento

E21 Dúvidas, sugestões e reclamações

E22 Satisfação dos consumidores / clientes

E23 Politica de comunicação comercial

E24 Conhecim con danos potenciais dos produtos e serviç

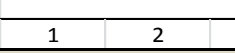

4

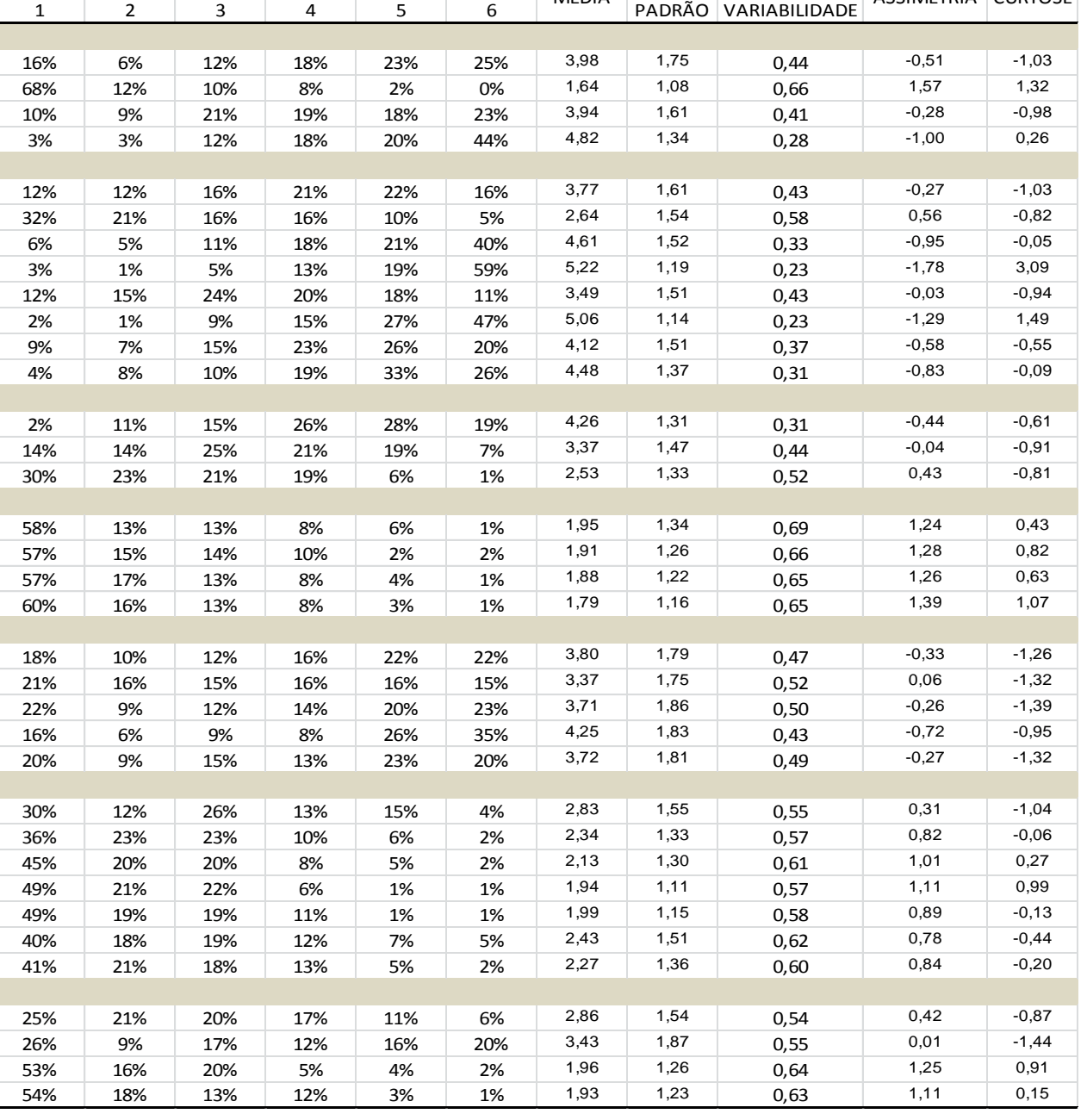

F25 Gerenciamento do impacto da empresa na comunidade do entorno

F26 Relacionamento com a comunidade do entorno

F27 Estímulo ao trabalho voluntário

F28 Envolvimento da empresa em ação social

F29 Relações com entidades beneficiadas

F30 Participação comunitária

F31 Benefícios para o n

G32 Participação e influência sindical

G33 Envolvimento em campanhas políticas

G34 Parlipação acompas

G35 Melhorias nos espaços públicos e apoio a iniciativas sociais governamentais 


\subsection{Análise multivariada}

A análise multivariada dos dados colhidos compreende: (1) análise da confiabilidade da escala; (2) teste do Outer Model (Modelo de Mensuração); (3) teste do Inner Model (Modelo Estrutural). Foram também aplicados testes estatísticos nos procedimentos de bootstrapping e identificação do número de segmentos dos respondentes.

\subsubsection{Teste de confiabilidade da escala}

Por meio do software SPSS, calculou-se a correlação item-total corrigida e os Alfas de Cronbach por constructo e total.

Os resultados dos testes de confiabilidade da escala por meio do Alfa de Cronbach, após as revisões empreendidas, serão apresentados na TAB.5.14. Essa tabela mostra a correlação item-total, o Alfa de Cronbach de cada constructo, o Alfa de Cronbach total e apresenta também o Alfa de Cronbach de cada constructo caso um dos indicadores fosse retirado. Com essa analise conclui-se que nenhum dos itens deve ser retirado, pois caso isto ocorra, o Alfa de Cronbach diminui.

Os constructos comunidade e fornecedor obtiveram Alfas de Cronbach acima de 0,90, ou seja, alcançaram um grau muito alto de confiabilidade, conforme mencionado na TAB.4.16.

Os constructos público interno, meio ambiente, cliente e governo/sociedade obtiveram Alfas de Cronbach entre 0,75 e 0,9 apresentando um alto grau de confiabilidade, segundo a classificação já descrita na TAB.4.16.

O constructo ética obteve um Alfa de Cronbach igual a 0,542, abaixo do limiar de 0,6 recomendado pela literatura. Os itens que deram origem ao problema foram o A2 ("O Instituto publica periodicamente um documento chamado - Balanço Social") e A4 ("O Instituto estabelece, implementa e mantém um Sistema de Gestão de Qualidade"). Os dois itens apresentam correlação itemtotal corrigido abaixo de $0,4(0,255$ e 0,328 respectivamente), indicando baixa consistência interna com a variável latente que se buscou mensurar. Uma possível explicação para esse problema deriva do fato de funcionários do IPEN terem certo desconhecimento dos temas abordados. 
Quando essa questão foi submetida ao CEN no pré-teste, esse problema não foi detectado, pois os funcionários do CEN possuem familiarização com esses assuntos, inclusive já passaram por processos de gestão da qualidade.

Optou-se por retirar o constructo ética pelos seguintes motivos: (1) mesmo retirando os dois itens problemáticos, o Alfa de Cronbach permaneceu abaixo do valor mínimo; (2) O constructo passou a contar com apenas duas variáveis. O resultado obtido indica que a escala proposta para ética precisaria de uma reformulação a fim de ser incluída no modelo, algo que se poderá incorporar em futuros estudos sobre a ética na responsabilidade social.

TABELA 5.14 - Análise de Confiabilidade Alfas de Cronbach - após revisão

\begin{tabular}{|c|c|c|c|}
\hline & $\begin{array}{c}\text { Correlação Item- } \\
\text { Total }\end{array}$ & $\begin{array}{l}\text { Alfa de Cronbach se } \\
\text { item for removido }\end{array}$ & Alfa de Cronbach \\
\hline Público Interno & & & 0,781 \\
\hline B5 & 0,651 & 0,722 & \\
\hline B6 & 0,364 & 0,775 & \\
\hline B7 & 0,419 & 0,766 & \\
\hline B8 & 0,415 & 0,765 & \\
\hline B9 & 0,369 & 0,774 & \\
\hline B10 & 0,492 & 0,755 & \\
\hline B11 & 0,577 & 0,738 & \\
\hline B12 & 0,597 & 0,736 & \\
\hline Meio Ambiente & & & 0,746 \\
\hline C13 & 0,516 & 0,732 & \\
\hline C14 & 0,724 & 0,474 & \\
\hline $\mathrm{C} 15$ & 0,508 & 0,741 & \\
\hline Fornecedor & & & 0,904 \\
\hline D16 & 0,771 & 0,881 & \\
\hline D17 & 0,805 & 0,867 & \\
\hline D18 & 0,835 & 0,857 & \\
\hline D19 & 0,730 & 0,894 & \\
\hline Cliente & & & 0,845 \\
\hline E20 & 0,640 & 0,816 & \\
\hline E21 & 0,758 & 0,784 & \\
\hline E22 & 0,694 & 0,801 & \\
\hline E23 & 0,597 & 0,828 & \\
\hline E24 & 0,573 & 0,834 & \\
\hline Comunidade & & & 0,903 \\
\hline F25 & 0,613 & 0,895 & \\
\hline F26 & 0,734 & 0,878 & \\
\hline $\mathrm{F} 27$ & 0,720 & 0,880 & \\
\hline F28 & 0,716 & 0,882 & \\
\hline F29 & 0,789 & 0,874 & \\
\hline F30 & 0,654 & 0,889 & \\
\hline F31 & 0,744 & 0,877 & \\
\hline Governo e Sociedade & & & 0,753 \\
\hline G32 & 0,565 & 0,635 & \\
\hline G33 & 0,409 & 0,761 & \\
\hline G34 & 0,605 & 0,627 & \\
\hline G35 & 0,567 & 0,649 & \\
\hline ESCALA COMPLETA & & & 0,923 \\
\hline
\end{tabular}


A interpretação do coeficiente alfa de Cronbach é quase intuitiva porque os valores variam em geral, entre zero e um e a confiabilidade é tanto maior quanto mais perto de 1 estiver o valor da estatística. O Alfa de Cronbach total do modelo analisado, excluindo o constructo ética, foi de 0,923 , que demonstra um grau de confiabilidade muito alto segundo a classificação apresentada na TAB.4.16.

Para efetuar as análises estatísticas relativas ao modelo teórico proposto, utilizou-se o software SmartPLS versão 2.0. O programa calcula simultaneamente todos os parâmetros, porém os modelos de mensuração (outer model) e estrutural (inner model) são analisados separadamente a seguir.

\subsubsection{Avaliação do Outer Model (Modelo de Mensuração)}

Conforme mencionado no capítulo quatro, a avaliação do outer model envolve examinar a significância de cada item, a confiabilidade das medidas compostas de cada constructo e as validades convergente e discriminante das medidas. Os critérios específicos recomendados para os modelos de mensuração reflexivos são: (1) confiabilidade, no qual se examina os outer loadings ou cargas fatoriais padronizadas e a consistência interna, na qual se verifica a confiabilidade composta e (2) validade, na qual se verifica a validade convergente por meio da média da variância extraída (Average Variance Extracted - AVE) e a validade discriminante, na qual se analisam as cargas cruzadas (cross-loadings) e a comparação da raiz quadrada da AVE com as correlações entre pares de constructos (HAIR et al., 2011, 2013).

\section{(1) Confiabilidade do Modelo de Mensuração}

A confiabilidade pode ser definida como o grau em que as medidas estão livres de erros e, consequentemente, produzem resultados consistentes (PETER, 1979). Normalmente, o primeiro critério de confiabilidade a ser validado é a consistência interna, cujo índice tradicional é o Alfa de Cronbach, que fornece uma estimativa de confiabilidade baseada nas intercorrelações entre os indicadores. No entanto, esse índice é limitado pela premissa de que todos os indicadores sejam igualmente confiáveis (HAIR et al., 2012). Isso tende a 
subestimar a consistência interna das variáveis latentes nos modelos de equações estruturais que utilizam a técnica PLS (HENSELER et al., 2009).

As medidas de confiabilidade utilizadas em modelagem de equações estruturais buscam suplantar as limitações verificadas no coeficiente Alfa de Cronbach (GARVER e MENTZER, 1999). Assim, é mais apropriado utilizar como medida de confiabilidade do constructo a confiabilidade composta, que considera que os indicadores possuem cargas diferentes (HENSELER et al., 2009). Isso a torna mais adequada, pois prioriza os indicadores de acordo com sua confiabilidade individual (HAIR et al., 2012). Segundo Hair et al., (2011), valores de confiabilidade composta entre 0,60 e 0,70 são satisfatórios para esse tipo de pesquisa.

Na TAB.5.15 são apresentados os índices de confiabilidade composta dos constructos presentes no modelo, obtidos pelo software SmartPLS. Todos estão acima de 0,83 , indicando que os constructos possuem confiabilidade. Nessa tabela, também são mostrados os índices referentes à AVE, Raiz Quadrada de AVE e $R^{2}$, que serão utilizados para a análise de validade discutida a seguir.

TABELA 5.15 - Resultados Gerais do Modelo

\begin{tabular}{cccc}
\hline Constructos & AVE & $\begin{array}{c}\text { Raiz Quadrada } \\
\text { de AVE }\end{array}$ & $\begin{array}{c}\text { Confiabilidade } \\
\text { Composta }\end{array}$
\end{tabular}$R^{2}$

Responsabilidade Social

0,877797

Além da confiabilidade composta, a confiabilidade individual de cada indicador também precisa ser considerada. Ela descreve o quanto uma variável é consistente com relação ao que se deseja medir. A confiabilidade de cada 
constructo é independente, sendo calculada separadamente da confiabilidade de outros constructos (URBACH e AHLEMANN, 2010).

Um constructo latente deve explicar uma parte substancial da variância de cada indicador. O grau normalmente aceito é de no mínimo 50\%. Dessa forma, as correlações absolutas entre o constructo e cada uma de suas variáveis (cargas fatoriais padronizadas - outer loadings) do modelo de mensuração devem ser maiores que 0,70 . Os valores entre 0,40 e 0,70 podem ou não ser considerados para remoção da escala, dependendo da sua influência nos resultados finais. A recomendação é que se eliminem os itens com cargas menores que 0,40 (HULLAND, 1999; URBACH e AHLEMANN, 2010).

$\mathrm{Na}$ TAB.5.16 são apresentadas as cargas fatoriais dos constructos do modelo de mensuração, obtidos pelo software SmartPLS. A codificação utilizada para os indicadores é apresentada no APÊNDICE B.

TABELA 5.16 - Cargas Fatoriais Padronizadas - Outer Loadings

\begin{tabular}{|c|c|c|c|c|c|c|}
\hline & Cliente & Comunidade & Fornecedor & $\begin{array}{l}\text { Governo/ } \\
\text { Sociedade }\end{array}$ & $\begin{array}{c}\text { Meio } \\
\text { Ambiente }\end{array}$ & $\begin{array}{l}\text { Público } \\
\text { Interno }\end{array}$ \\
\hline B10 & & & & & & 0,573998 \\
\hline B11 & & & & & & 0,761944 \\
\hline B12 & & & & & & 0,768273 \\
\hline B5 & & & & & & 0,786502 \\
\hline B6 & & & & & & 0,559183 \\
\hline B7 & & & & & & 0,493575 \\
\hline B8 & & & & & & 0,475712 \\
\hline B9 & & & & & & 0,536127 \\
\hline C13 & & & & & 0,750082 & \\
\hline C14 & & & & & 0,890159 & \\
\hline C15 & & & & & 0,800023 & \\
\hline D16 & & & 0,867325 & & & \\
\hline D17 & & & 0,894813 & & & \\
\hline D18 & & & 0,917984 & & & \\
\hline D19 & & & 0,846051 & & & \\
\hline E20 & 0,762181 & & & & & \\
\hline E21 & 0,854231 & & & & & \\
\hline E22 & 0,804144 & & & & & \\
\hline E23 & 0,739976 & & & & & \\
\hline E24 & 0,762339 & & & & & \\
\hline F25 & & 0,731373 & & & & \\
\hline F26 & & 0,824266 & & & & \\
\hline F27 & & 0,811972 & & & & \\
\hline
\end{tabular}


TABELA 5.16 - Cargas Fatoriais Padronizadas - Outer Loadings (continuação)

\begin{tabular}{|c|c|c|c|c|c|c|}
\hline & Cliente & Comunidade & Fornecedor & $\begin{array}{l}\text { Governo/ } \\
\text { Sociedade }\end{array}$ & $\begin{array}{c}\text { Meio } \\
\text { Ambiente }\end{array}$ & $\begin{array}{l}\text { Público } \\
\text { Interno }\end{array}$ \\
\hline F28 & & 0,793961 & & & & \\
\hline F29 & & 0,848422 & & & & \\
\hline F30 & & 0,738369 & & & & \\
\hline F31 & & 0,812226 & & & & \\
\hline G32 & & & & 0,780373 & & \\
\hline G33 & & & & 0,588549 & & \\
\hline G34 & & & & 0,836325 & & \\
\hline G35 & & & & 0,814357 & & \\
\hline
\end{tabular}

Todas as cargas ficaram acima do patamar de 0,70 , exceto B6 (com carga 0,6); B7 (com carga 0,5); B8 (com carga 0,5); B9 (com carga 0,5) e B10 (com carga 0,6$)$. Todos esses são indicadores do constructo público interno e esses indicadores, embora abaixo do patamar que é 0,7 , ficaram com carga acima de 0,4. Segundo Hulland (1999) e Urbach e Ahlemann (2010), a recomendação mais usual é que se eliminem apenas os itens com cargas menores que 0,4.

Além disso, a confiabilidade composta do constructo Público Interno, considerando as cargas obtidas com os itens acima, é de $(0,836169)$. A confiabilidade composta sem esses itens é de $(0,879721)$. Os dois casos estão acima do valor limite que é 0,70 , e o aumento não foi muito representativo, portanto, optou-se por não retirar esses indicadores do modelo.

\section{(2) Validade do Modelo de Mensuração}

Nos modelos de mensuração reflexivos, o enfoque da análise da validade dos constructos incide sobre os aspectos de convergência e discriminância entre eles.

A validade convergente mede em que grau convergem os itens individuais que refletem um constructo em comparação com os itens que medem constructos diferentes (URBACH e AHLEMANN, 2010). .

$\mathrm{Na}$ modelagem de equações estruturais pela técnica PLS, a validade convergente é dada pela média da variância extraída (Average Variance Extrated - AVE), que mede a variância capturada de cada item pelos constructos latentes (GEFEN e STRAUB, 2005). Conforme mencionado no capítulo quatro, seu valor 
deve ser de no mínimo 0,50, indicando que a variável latente explica mais da metade da variância do indicador (HAIR et al., 2011). Os valores da AVE do modelo proposto são apresentados na TAB.5.15. Todos excedem ou estão bem próximos do valor mínimo, apresentando, portanto, índices satisfatórios de validade convergente.

O complemento metodológico tradicional da validade convergente é a validade discriminante, que representa o quanto cada medida de um dado constructo difere das medidas dos outros constructos presentes no mesmo modelo (URBACH e AHLEMANN, 2010). Para a PLS, o critério para verificar se a validade discriminante é adequada, consiste em que o constructo compartilhe mais variância com suas medidas do que com os outros constructos do modelo (HULLAND, 1999).

Para verificar a validade discriminante, utilizou-se o critério indicado por Gefen e Straub (2005), em que a raiz quadrada da AVE de cada constructo deve ser maior do que qualquer outra correlação entre pares de constructos latentes. Isso pode ser demonstrado em uma matriz que inclua as correlações entre os diferentes constructos abaixo da diagonal principal e as raízes quadradas da AVE calculadas para cada constructo ao longo dessa diagonal. Quando a validade discriminante é adequada, os valores da diagonal devem ser significativamente mais altos que os valores abaixo dela, nas linhas e colunas correspondentes (HULLAND, 1999).

Assim, pode-se analisar a validade discriminante tanto no nível do constructo, como no nível dos indicadores (HENSELER, RINGLE e SINKOVICS, 2009). A ideia é que um constructo deve estar mais fortemente correlacionado com seus próprios indicadores do que com outros constructos, caso contrário, a maior parte da variância da dimensão está sendo compartilhada com outras dimensões, não lhe podendo ser atribuída a validade discriminante.

$\mathrm{Na}$ TAB.5.17, temos a matriz que compara a raiz quadrada da AVE (que está na diagonal principal) de cada constructo com as correlações entre todos os possíveis pares de constructos latentes, podendo-se verificar que nenhuma correlação (valores abaixo da diagonal principal) apresentou valor superior à AVE. Os valores foram obtidos a partir do software SmartPLS. 
TABELA 5.17 - Validade Discriminante

\begin{tabular}{ccccccc}
\hline & Cliente & Comunidade & Fornecedor & $\begin{array}{c}\text { Governo/ } \\
\text { Sociedade }\end{array}$ & $\begin{array}{c}\text { Meio } \\
\text { Ambiente }\end{array}$ & $\begin{array}{c}\text { Público } \\
\text { Interno }\end{array}$ \\
\hline Cliente & $\mathbf{0 , 7 8 5 6 2}$ & & & & & \\
Comunidade & 0,244408 & $\mathbf{0 , 7 9 5 4 0 7 4 4}$ & & & & \\
Fornecedor & 0,430574 & 0,584748 & $\mathbf{0 , 8 8 1 9 6 3 7}$ & & & \\
Governo/Sociedade & 0,379089 & 0,726707 & 0,535247 & $\mathbf{0 , 7 6 1 2 4 7}$ & & \\
Meio Ambiente & 0,379902 & 0,480494 & 0,454666 & 0,480051 & $\mathbf{0 , 8 1 5 4 8 4}$ & \\
Público Interno & 0,513085 & 0,319928 & 0,295084 & 0,448065 & 0,586917 & $\mathbf{0 , 6 3 1 3 6}$ \\
\hline
\end{tabular}

Outra forma de confirmar a validade discriminante é a análise das cargas cruzadas, obtidas quando se correlaciona os scores dos componentes de cada variável latente com todos os scores dos outros itens (GEFEN e STRAUB, 2005). Caso um dos indicadores tenha uma correlação mais alta com outra variável latente do que com sua respectiva variável, a adequação do modelo deve ser considerada. Se a carga de cada indicador for maior em relação ao seu respectivo constructo do que com qualquer outro, pode-se inferir que esses indicadores não são intercambiáveis e que os constructos do modelo diferem substancialmente uns dos outros (URBACH e AHLEMANN, 2010).

$\mathrm{Na}$ TAB.5.18 observa-se que nenhuma carga cruzada (cross-loading) resultou em valores maiores do que as cargas entre os indicadores e seus respectivos constructos. Os resultados foram gerados pelo software SmartPLS.

Assim, observa-se que o modelo proposto possui confiabilidade e validade satisfatórias. Uma vez analisadas a validade e a confiabilidade dos constructos contidos no modelo de mensuração (outer model), o próximo passo na modelagem de equações estruturais é a análise do modelo estrutural (inner model). 
TABELA 5.18 - Cargas (Outer Loadings) e Cargas Cruzadas (Cross-Loadings)

\begin{tabular}{|c|c|c|c|c|c|c|c|}
\hline & Cliente & Comunidade & Fornecedor & $\begin{array}{l}\text { Governo/ } \\
\text { Sociedade }\end{array}$ & $\begin{array}{c}\text { Meio } \\
\text { Ambiente }\end{array}$ & $\begin{array}{l}\text { Público } \\
\text { Interno }\end{array}$ & Total \\
\hline B10 & 0,248447 & $-0,065800$ & $-0,009755$ & 0,100325 & 0,230785 & 0,573998 & 0,262469 \\
\hline B11 & 0,329915 & 0,289664 & 0,231990 & 0,379983 & 0,462095 & 0,761944 & 0,563579 \\
\hline B12 & 0,391904 & 0,269725 & 0,171911 & 0,333361 & 0,465226 & 0,768273 & 0,582046 \\
\hline B5 & 0,412964 & 0,225237 & 0,289151 & 0,347075 & 0,458761 & 0,786502 & 0,565671 \\
\hline B6 & 0,325656 & 0,366560 & 0,329411 & 0,405565 & 0,371556 & 0,559183 & 0,521334 \\
\hline B7 & 0,281111 & 0,019714 & 0,011755 & 0,124726 & 0,124959 & 0,493575 & 0,285704 \\
\hline B8 & 0,315431 & 0,041448 & $-0,049527$ & 0,074399 & 0,122399 & 0,475712 & 0,286430 \\
\hline B9 & 0,261097 & 0,203466 & 0,271493 & 0,275095 & 0,502443 & 0,536127 & 0,437242 \\
\hline C13 & 0,346251 & 0,259884 & 0,257690 & 0,341441 & 0,750082 & 0,519973 & 0,465175 \\
\hline C14 & 0,324504 & 0,378098 & 0,307801 & 0,352659 & 0,890159 & 0,539688 & 0,527794 \\
\hline C15 & 0,266367 & 0,513071 & 0,522350 & 0,468846 & 0,800023 & 0,388080 & 0,566979 \\
\hline D16 & 0,350371 & 0,513953 & 0,867325 & 0,429600 & 0,417704 & 0,251367 & 0,529914 \\
\hline D17 & 0,397663 & 0,466265 & 0,894813 & 0,468950 & 0,414388 & 0,301555 & 0,576391 \\
\hline D18 & 0,423590 & 0,593845 & 0,917984 & 0,531361 & 0,424233 & 0,280894 & 0,625213 \\
\hline D19 & 0,341050 & 0,482890 & 0,846051 & 0,451186 & 0,345973 & 0,202777 & 0,543079 \\
\hline E20 & 0,762181 & 0,077083 & 0,264743 & 0,287006 & 0,197391 & 0,316108 & 0,436582 \\
\hline E21 & 0,854231 & 0,248937 & 0,368554 & 0,335710 & 0,255968 & 0,400129 & 0,534017 \\
\hline E22 & 0,804144 & 0,154620 & 0,345406 & 0,201666 & 0,232808 & 0,443197 & 0,463609 \\
\hline E23 & 0,739976 & 0,083661 & 0,239738 & 0,201199 & 0,329178 & 0,359135 & 0,426132 \\
\hline E24 & 0,762339 & 0,327306 & 0,427479 & 0,412248 & 0,435429 & 0,468319 & 0,617675 \\
\hline F25 & 0,349354 & 0,731373 & 0,490656 & 0,526105 & 0,463284 & 0,326350 & 0,609113 \\
\hline F26 & 0,267983 & 0,824266 & 0,542531 & 0,631371 & 0,420973 & 0,279042 & 0,622705 \\
\hline F27 & 0,189813 & 0,811972 & 0,504017 & 0,543505 & 0,449666 & 0,277189 & 0,572441 \\
\hline F28 & 0,110800 & 0,793961 & 0,442764 & 0,577285 & 0,300030 & 0,213371 & 0,509769 \\
\hline F29 & 0,101504 & 0,848422 & 0,428986 & 0,607424 & 0,294195 & 0,191085 & 0,514074 \\
\hline F30 & 0,145057 & 0,738369 & 0,356817 & 0,500643 & 0,371390 & 0,262594 & 0,489505 \\
\hline F31 & 0,150633 & 0,812226 & 0,455512 & 0,648539 & 0,342774 & 0,211135 & 0,547358 \\
\hline G32 & 0,360269 & 0,487918 & 0,410136 & 0,780373 & 0,447165 & 0,430029 & 0,602651 \\
\hline G33 & 0,370577 & 0,248710 & 0,206367 & 0,588549 & 0,186083 & 0,384500 & 0,391878 \\
\hline G34 & 0,264822 & 0,673466 & 0,497505 & 0,836325 & 0,375993 & 0,309617 & 0,612754 \\
\hline G35 & 0,196428 & 0,726638 & 0,464687 & 0,814357 & 0,407776 & 0,267803 & 0,575532 \\
\hline Total & 0,643665 & 0,700160 & 0,646593 & 0,727349 & 0,641670 & 0,734791 & 1,000000 \\
\hline
\end{tabular}




\subsubsection{Avaliação do Inner Model (Modelo Estrutural) e das hipóteses}

A validação do modelo de mensuração (outer model) permitiu prosseguir para a próxima etapa de avaliação do modelo estrutural (inner model) (HENSELER et al., 2009).

No método PLS-SEM, o indicador que melhor reflete o ajuste do modelo estrutural é o coeficiente de determinação $\left(\boldsymbol{R}^{2}\right)$, que representa a porção da variância explicada de cada variável endógena (HAIR et al., 2012).

O valor do $\boldsymbol{R}^{2}$ do modelo proposto para a responsabilidade social foi de 0,877797, como demonstrado na TAB.5.15. Esse valor está bem acima do valor mínimo de 0,75 , que é considerado substancial. Com isso, pode-se afirmar que o modelo é adequado para explicar o constructo dependente responsabilidade social do IPEN, bem como os fatores antecedentes que o influenciam.

\section{Avaliação dos Path Coefficients(Coeficientes de Caminhos)}

O passo seguinte na análise do modelo estrutural é o exame dos path coefficients. Deve-se verificar o sinal, a magnitude e a significância dos coeficientes de caminhos.

Os valores dos path coefficients do modelo estrutural devem ser maiores que 0,10 , e a significância menor que 0,05.

A dimensão público interno destaca-se como a que exerce maior impacto sobre a responsabilidade social (path coefficient $=0,382$ ), conforme demonstrado na TAB.5.19. A dimensão com menor impacto é meio ambiente (path coefficient $=$ 0,041). As dimensões cliente, fornecedor e governo/sociedade com path coefficients $0,235,0,161$ e 0,139, respectivamente, exercem impacto mediano sobre a responsabilidade social , como pode ser observado naTAB.5.19.

$\mathrm{Na}$ verdade, todas as dimensões demonstraram exercer impacto sobre o constructo responsabilidade social em termos de magnitude.

A TAB.5.19 apresenta também os valores do $t$ de student (teste $t$ ) para os path coefficients, mostrando que todos são significantes, ou seja, significância $(p)<0,01$. Os valores foram obtidos a partir do software SmartPLS. 
TABELA 5.19 - Teste dos Path Coefficients

\begin{tabular}{lccl}
\hline & Responsabilidade Social & Valor $\boldsymbol{t}$ & $\mathrm{S} / \mathrm{NS}$ \\
\hline Cliente & 0,235 & 3,754 & $\mathrm{~S}^{* * *}$ \\
Comunidade & 0,306 & 2,235 & $\mathrm{~S}^{* * *}$ \\
Fornecedor & 0,161 & 1,874 & $\mathrm{~S}^{* * *}$ \\
Governo/Sociedade & 0,139 & 2,376 & $\mathrm{~S}^{* * *}$ \\
Meio Ambiente & 0,041 & 3,368 & $\mathrm{~S}^{* * *}$ \\
Público Interno & 0,382 & 4,218 & $\mathrm{~S}^{* * *}$ \\
\hline
\end{tabular}

$\mathrm{S}^{* * *}$ valores significativos $p<0,01$

Tendo em vista a magnitude, o sinal e o teste de significância dos path coefficients diferentes de zero, pode-se afirmar que as hipóteses formuladas para o modelo proposto não podem ser rejeitadas, como demonstrado na TAB.5.20. Os valores foram extraídos a partir do software SmartPLS.

TABELA 5.20 - Teste das Hipóteses

\begin{tabular}{lcccc}
\hline & $\begin{array}{c}\text { Coeficientes } \\
\text { dos } \\
\text { Caminhos }\end{array}$ & Sinal & Teste $\boldsymbol{t}$ & Resultado \\
\hline H5 - Cliente ==> Valor & 0,235 & $(+)$ & $\mathrm{S}^{* * *}$ & Não Rejeitada \\
H6 - Comunidade ==> Valor & 0,306 & $(+)$ & $\mathrm{S}^{* * *}$ & Não Rejeitada \\
H4 - Fornecedor ==> Valor & 0,161 & $(+)$ & $\mathrm{S}^{* * *}$ & Não Rejeitada \\
H7 - Governo/Sociedade ==> Valor & 0,139 & $(+)$ & $\mathrm{S}^{* * *}$ & Não Rejeitada \\
H3 - Meio Ambiente ==> Valor & 0,041 & $(+)$ & $\mathrm{S}^{* * *}$ & Não Rejeitada \\
H2 - Público Interno $==>$ Valor & 0,382 & $(+)$ & $\mathrm{S}^{* * *}$ & Não Rejeitada \\
\hline
\end{tabular}

$\mathrm{S}^{* * *}$ valores significativos $p<0,01$

Na FIG.5.39, o modelo proposto é representado graficamente, indicando os Outer Loadings do modelo de mensuração, os path coefficients do modelo estrutural e $\circ R^{2}$ do constructo responsabilidade social. Essa figura foi gerada pelo software SmartPLS. 


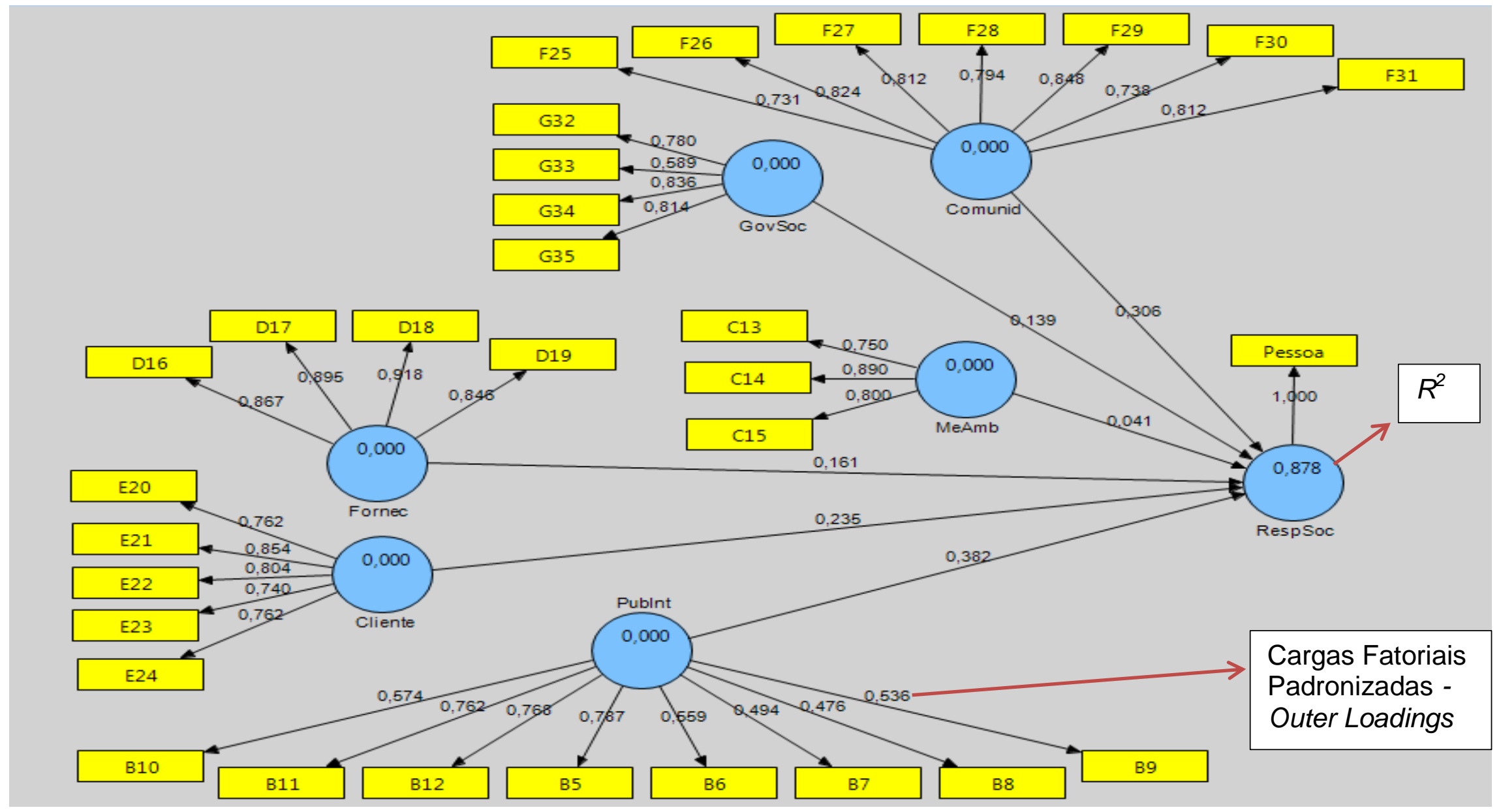

FIGURA 5.39 - O Modelo Teórico Proposto Testado 


\section{Teste da validade do modelo usando Bootstrapping}

Como já visto na teoria, esse teste avalia quão estáveis estão os coeficientes das relações entre os constructos do modelo teórico.

O algoritmo da PLS-SEM estima o resultado das equações estruturais para cada amostra de bootstrapping, gerando uma distribuição para cada parâmetro estimado do modelo, que pode ser vista como uma aproximação da distribuição da amostra empírica, com erro-padrão para cada coeficiente.

Com isso, um teste $t$ pode ser realizado para medir a significância das diferenças entre os path coefficients do modelo da amostra original com os betas médios do bootstrapping (HENSELER et al., 2009).

A técnica de bootstrapping foi realizada com 500 sub-amostras com 150 casos cada. Na TAB.5.21, os resultados do procedimento são apresentados e demonstram que não houve diferenças estatisticamente significativas entre os coeficientes da amostra original em relação à média dos coeficientes das novas amostras geradas, confirmando, assim, a validade do modelo. Esse resultado foi obtido por meio do software SmartPLS.

TABELA 5.21 - Análise dos Path Coefficients por Bootstrapping

\begin{tabular}{lccccc}
\hline & $\begin{array}{c}\text { Média } \\
\text { da } \\
\text { Amostra } \\
\text { Original }\end{array}$ & $\begin{array}{c}\text { Média } \\
\text { das 500 } \\
\text { Amostras }\end{array}$ & $\begin{array}{c}\text { Erro } \\
\text { Padrão }\end{array}$ & $\begin{array}{c}\text { Valor } \\
\text { Calculado } \\
\text { de } \boldsymbol{t}\end{array}$ & $\begin{array}{c}\text { Teste } \\
\boldsymbol{t} \\
\text { S/SN }\end{array}$ \\
\hline Cliente -> Resp. Social & 0,235 & 0,235 & 0,038 & 6,237 & $\mathrm{~S}^{* * *}$ \\
Comunidade -> Resp. Social & 0,306 & 0,302 & 0,052 & 5,887 & $\mathrm{~S}^{* * *}$ \\
Fornecedor -> Resp. Social & 0,161 & 0,161 & 0,039 & 4,145 & $\mathrm{~S}^{* * *}$ \\
Governo/Sociedade -> Resp. Social & 0,139 & 0,142 & 0,042 & 3,276 & $\mathrm{~S}^{* * *}$ \\
Meio Ambiente -> Resp. Social & 0,041 & 0,039 & 0,039 & 1,053 & $\mathrm{~S}^{* * *}$ \\
Público Interno -> Resp. Social & 0,382 & 0,384 & 0,038 & 10,084 & $\mathrm{~S}^{* * *}$ \\
\hline
\end{tabular}

$\mathrm{S}^{\star * *}$ valores significativos $p<0,01$

O mesmo procedimento foi realizado para cada indicador relacionado com seu respectivo constructo. Os indicadores estão descritos no APÊNDICE B. O procedimento de bootstrapping, nesse caso, também apresenta os resultados do teste $t$ para os parâmetros do modelo de mensuração. A TAB.5.22 mostra que todas as cargas dos indicadores são válidas, visto que não houve diferenças significativas entre os valores da amostra original e os das médias das amostras 
geradas por bootstrapping e os erros-padrão foram baixos. Segundo Hair et al. (2006), um erro-padrão menor implica em uma previsão mais confiável e, consequentemente, em menores intervalos de confiança. Os resultados apresentados na TAB. 5.22 foram extraídos do software SmartPLS.

TABELA 5.22 - Análise das Cargas do Outer Model por Bootstrapping

\begin{tabular}{|c|c|c|c|c|c|}
\hline & $\begin{array}{c}\text { Média } \\
\text { da } \\
\text { Amostra } \\
\text { Original }\end{array}$ & $\begin{array}{c}\text { Média das } \\
500 \\
\text { Amostras }\end{array}$ & $\begin{array}{c}\text { Erro } \\
\text { Padrão }\end{array}$ & $\begin{array}{l}\text { Valor } \\
\text { Calculado } \\
\text { de } t\end{array}$ & $\begin{array}{c}\text { Teste } t \\
\text { S/SN }\end{array}$ \\
\hline B10 <- Público Interno & 0,115 & 0,112 & 0,027 & 4,320 & $\mathrm{~S} * * *$ \\
\hline B11 <- Público Interno & 0,248 & 0,247 & 0,024 & 10,356 & $\mathrm{~S} * * *$ \\
\hline B12 <- Público Interno & 0,256 & 0,256 & 0,022 & 11,529 & $\mathrm{~S} * * *$ \\
\hline B5 <- Público Interno & 0,249 & 0,247 & 0,021 & 12,019 & $\mathrm{~S} * * *$ \\
\hline B6 <- Público Interno & 0,229 & 0,231 & 0,026 & 8,716 & $\mathrm{~S} * * *$ \\
\hline B7 <- Público Interno & 0,126 & 0,122 & 0,027 & 4,665 & $\mathrm{~S} * * *$ \\
\hline B8 <-Público Interno & 0,126 & 0,123 & 0,032 & 3,965 & $\mathrm{~S} * * *$ \\
\hline B9 <- Público Interno & 0,192 & 0,191 & 0,025 & 7,623 & $\mathrm{~S} * * *$ \\
\hline C13 <- Meio Ambiente & 0,366 & 0,364 & 0,035 & 10,548 & $\mathrm{~S} * * *$ \\
\hline C14 <- Meio Ambiente & 0,415 & 0,414 & 0,027 & 15,208 & $\mathrm{~S} * * *$ \\
\hline C15 <- Meio Ambiente & 0,446 & 0,448 & 0,036 & 12,251 & $\mathrm{~S} * * *$ \\
\hline D16 <- Fornecedor & 0,264 & 0,263 & 0,016 & 16,442 & $\mathrm{~S} * * *$ \\
\hline D17 <- Fornecedor & 0,287 & 0,287 & 0,020 & 14,458 & $\mathrm{~S} * * *$ \\
\hline D18 <- Fornecedor & 0,311 & 0,311 & 0,015 & 20,934 & $\mathrm{~S} * * *$ \\
\hline D19 <- Fornecedor & 0,270 & 0,271 & 0,022 & 12,335 & $\mathrm{~S} * * *$ \\
\hline E20 <- Cliente & 0,224 & 0,222 & 0,022 & 10,339 & $\mathrm{~S} * * *$ \\
\hline E21 <- Cliente & 0,274 & 0,273 & 0,020 & 13,591 & $\mathrm{~S} * * *$ \\
\hline E22 <- Cliente & 0,238 & 0,237 & 0,021 & 11,179 & $\mathrm{~S} * * *$ \\
\hline E23 <- Cliente & 0,219 & 0,219 & 0,028 & 7,881 & $\mathrm{~S} * * *$ \\
\hline E24 <- Cliente & 0,317 & 0,318 & 0,028 & 11,325 & $\mathrm{~S} * * *$ \\
\hline F25 <- Comunidade & 0,198 & 0,200 & 0,020 & 9,878 & $\mathrm{~S} * * *$ \\
\hline F26 <- Comunidade & 0,203 & 0,202 & 0,015 & 13,110 & $\mathrm{~S} * * *$ \\
\hline F27 <- Comunidade & 0,186 & 0,186 & 0,014 & 13,181 & $\mathrm{~S} * * *$ \\
\hline F28 <- Comunidade & 0,166 & 0,166 & 0,012 & 13,559 & $\mathrm{~S} * * *$ \\
\hline F29 <- Comunidade & 0,167 & 0,166 & 0,012 & 13,589 & $\mathrm{~S} * * *$ \\
\hline F30 <- Comunidade & 0,159 & 0,160 & 0,013 & 12,333 & $\mathrm{~S} * * *$ \\
\hline F31 <- Comunidade & 0,178 & 0,177 & 0,012 & 14,665 & $\mathrm{~S} * * *$ \\
\hline G32 <- Governo e Sociedade & 0,358 & 0,360 & 0,030 & 12,130 & $\mathrm{~S} * * *$ \\
\hline G33 <- Governo e Sociedade & 0,233 & 0,233 & 0,031 & 7,560 & $\mathrm{~S} * * *$ \\
\hline G34 <- Governo e Sociedade & 0,364 & 0,366 & 0,024 & 14,921 & $\mathrm{~S} * * *$ \\
\hline G35 <- Governo e Sociedade & 0,342 & 0,342 & 0,023 & 14,964 & $\mathrm{~S} * * *$ \\
\hline
\end{tabular}

$\mathrm{S}^{\star * *}$ valores significativos $p<0,01$ 
Com base nos resultados do procedimento de bootstrapping, pode-se confirmar novamente a validade do modelo proposto.

\section{Teste do Effect Size $\left(f^{2}\right)$}

Os caminhos do modelo teórico devem ser também analisados em termos do tamanho do efeito (effect size) para distinguir quais deles contribuem mais para a explicação da variável dependente à qual estão associados.

Valores de $f^{2}$ entre 0,02 e 0,15, entre 0,15 e 0,35, e acima de 0,35 indicam que uma variável latente exógena tem um efeito respectivamente pequeno, médio ou grande sobre uma variável latente endógena (URBACH e AHLEMANN, 2010).

Pelos resultados desse teste, apresentado na TAB.5.23, verifica-se que a variável latente exógena público interno tem um grande efeito sobre a variável latente endógena responsabilidade social. As variáveis latentes exógenas comunidade e cliente têm um médio efeito na variável latente endógena responsabilidade social. As variáveis fornecedor, governo/sociedade e meio ambiente tem um pequeno efeito sobre a variável responsabilidade social. Os resultados da TAB. 5.23 foram extraídos do software SmartPLS.

TABELA 5.23 - Effect Size $\boldsymbol{f}^{2}$

\begin{tabular}{lccc}
\hline \multicolumn{1}{c}{ Variável Omitida } & $R^{2}$ Total & $R^{2}$ Main Effects & $f^{2}$ \\
\hline Cliente -> Resp. Social & 0,877797 & 0,842776 & 0,287 \\
Comunidade - > Resp. Social & 0,877797 & 0,841065 & 0,301 \\
Fornecedor - > Resp. Social & 0,877797 & 0,863774 & 0,115 \\
Governo/Sociedade -> Resp. Social & 0,877797 & 0,870032 & 0,064 \\
Meio Ambiente -> Resp. Social & 0,877797 & 0,876883 & 0,007 \\
Público Interno - > Resp. Social & 0,877797 & 0,800595 & 0,632 \\
\hline
\end{tabular}




\section{Teste da Relevância Preditiva do Modelo Estrutural}

Uma forma alternativa de avaliação do modelo estrutural é medir sua capacidade de prever adequadamente cada indicador do constructo latente endógeno (HENSELER et al., 2009). Para tanto o índice mais comumente utilizado é a medida $\boldsymbol{Q}^{2}$.

Como visto anteriormente, para esse cálculo é necessário escolher uma distância $D$ para a omissão dos dados, no caso do presente estudo, a técnica de blindfolding foi realizada com uma distância $D=7$.

Os resultados dessa variável, indicados na TAB.5.24, foram gerados pelo software SmartPLS. Segundo eles, todos os constructos latentes apresentaram relevância preditiva.

TABELA 5.24 - Cross-Validate Redundancy $\left(\boldsymbol{Q}^{2}\right)$

\section{Cross-Validates Redundancy $\left(Q^{2}\right)$}

\begin{tabular}{ll}
\hline Cliente & 0,425 \\
Comunidade & 0,506 \\
Fornecedor & 0,616 \\
Governo/Sociedade & 0,313 \\
Meio Ambiente & 0,328 \\
Público Interno & 0,238 \\
\hline Responsabilidade Social & 0,848 \\
\hline
\end{tabular}

\section{Teste da Heterogeneidade dos Dados}

Para testar os possíveis problemas com a heterogeneidade dos dados, utilizou-se a técnica de mistura de mínimos quadrados parcial conhecida como FIMIX-PLS. Foram testados números alternativos de segmentos para escolher aquele que apresenta o menor valor dos critérios Consistent Akaike Information Criterion - CAIC e Bayes Information Criterion - BIC. Paralelamente, foi examinado o valor normalizado da entropia $(E N)$, que deve variar entre 0 e 1. Valores próximos a 0,50 indicam classes bem distintas. 
As seguintes alternativas de segmentação com 2, 3 e 4 segmentos foram testadas. Os indicadores CAIC, BIC e EN foram comparados nos três casos, bem como o tamanho proporcional de cada segmento e podem ser observados na TAB.5.25.

Os melhores indicadores foram aqueles da solução com dois grupos, pois a entropia está maior e os indicadores BIC e CAIC estão menores.

Os resultados da TAB. 5.25 foram gerados pelo software SmartPLS.

TABELA 5.25 - Critérios de Avaliação e Tamanhos Relativos dos Segmentos FIMIX

\begin{tabular}{|c|c|c|c|c|c|c|c|}
\hline \multirow{2}{*}{$\begin{array}{l}\text { Número de } \\
\text { Segmentos }\end{array}$} & \multirow[b]{2}{*}{ BIC } & \multirow[b]{2}{*}{ CAIC } & \multirow[b]{2}{*}{ Entropia } & \multicolumn{4}{|c|}{ Tamanho relativo dos segmentos } \\
\hline & & & & $s=1$ & $s=2$ & $s=3$ & $s=4$ \\
\hline 2 & 241,254205 & 241,341162 & 0,759733 & 0,88 & 0,12 & & \\
\hline 3 & 317,033972 & 317,167305 & 0,669837 & 0,12 & 0,67 & 0,21 & \\
\hline 4 & 327,541367 & 327,721077 & 0,727998 & 0,12 & 0,60 & 0,05 & 0,23 \\
\hline
\end{tabular}

Para confirmar esses resultados, uma análise de clusters foi conduzida utilizando um método hierárquico em dois passos (two-step cluster analysis). Ressalta-se que os dois grupos são muito díspares de tamanho: $88 \%$ e $12 \%$. Isso revela que a amostra é bastante homogênea, não revelando problemas de heterogeneidade não observada dos dados.

A análise de FIMIX gerou os path coefficients para os segmentos, que são apresentados na TAB.5.26. Esses resultados foram extraídos do software SmartPLS. Com referência aos impactos que as dimensões latentes exercem sobre o constructo endógeno responsabilidade social, tem-se que o Cluster 1, que representa $88 \%$ da amostra, apresenta coeficientes mais altos que o Cluster 2 nas dimensões cliente e comunidade; no entanto mostra coeficientes mais baixos nas dimensões fornecedor, governo/sociedade, meio ambiente e público interno. 
TABELA 5.26 - Path Coefficients para Dois Clusters

\begin{tabular}{lcc}
\hline & Cluster 1 & Cluster 2 \\
\hline Cliente & 0,233 & 0,085 \\
Comunidade & 0,376 & $-0,146$ \\
Fornecedor & 0,138 & 0,308 \\
Governo/Sociedade & 0,108 & 0,338 \\
Meio Ambiente & 0,012 & 0,248 \\
Público Interno & 0,352 & 0,686 \\
\hline
\end{tabular}

No que se refere à hierarquia dos path coefficients (do maior para o menor em módulo) e em termos de magnitude, o cluster 1 está muito mais próximo da hierarquia da amostra total (TAB.5.27).

TABELA 5.27 - Ordem de Magnitude dos Path Coefficients

\begin{tabular}{lccc}
\hline & Hierarquia dos Path Coefficients & \\
\hline Cluster 1 & Cluster 2 & $\begin{array}{c}\text { Amostra } \\
\text { total }\end{array}$ \\
\hline Cliente & 3 & 6 & 3 \\
Comunidade & 1 & 5 & 2 \\
Fornecedor & 4 & 3 & 4 \\
Governo/Sociedade & 5 & 2 & 5 \\
Meio Ambiente & 6 & 4 & 6 \\
Público Interno & 2 & 1 & 1 \\
\hline
\end{tabular}

Para verificar se as características do perfil da amostra poderiam discernir entre os dois segmentos e também em relação à amostra total, fez-se um cruzamento dessas variáveis com os dois clusters identificados.

Esse resultado é apresentado na TAB.5.28, na qual se pode constatar que o cluster 1 está bem próximo dos resultados da amostra total. Isso ocorre provavelmente pelo fato da quantidade de pessoas considerada no cluster 1 (88\%) ser bem superior à quantidade considerada no cluster 2 (12\%). Os resultados da TAB. 5.28 foram gerados com base nos resultados do software SmartPLS, com o auxílio do software MS-Excel. 
TABELA 5.28 - Perfil dos respondentes por Cluster e amostra total

\begin{tabular}{|c|c|c|c|c|}
\hline \multicolumn{2}{|c|}{ Perfil dos Respondentes } & \multirow{2}{*}{$\begin{array}{c}\text { Cluster } \\
\mathbf{1} \\
65 \%\end{array}$} & \multirow{2}{*}{$\begin{array}{c}\text { Cluster } \\
\mathbf{2} \\
73 \%\end{array}$} & \multirow{2}{*}{$\begin{array}{c}\begin{array}{c}\text { Amostra } \\
\text { Total }\end{array} \\
66 \%\end{array}$} \\
\hline SEYO & Masculino & & & \\
\hline SEXU & Feminino & $35 \%$ & $27 \%$ & $34 \%$ \\
\hline \multirow{5}{*}{ FAIXA ETÁRIA } & 26 a 35 anos & $3 \%$ & $9 \%$ & $4 \%$ \\
\hline & 36 a 45 anos & $13 \%$ & $9 \%$ & $13 \%$ \\
\hline & 46 a 55 anos & $52 \%$ & $55 \%$ & $53 \%$ \\
\hline & 57 a 65 anos & $26 \%$ & $23 \%$ & $25 \%$ \\
\hline & Acima de 65 anos & $5 \%$ & $5 \%$ & $5 \%$ \\
\hline \multirow{5}{*}{ TEMPO DE INSTITUIÇÃO } & 0 a 5 anos & $9 \%$ & $9 \%$ & $10 \%$ \\
\hline & 6 a 10 anos & $2 \%$ & $5 \%$ & $2 \%$ \\
\hline & 11 a 20 anos & $17 \%$ & $18 \%$ & $16 \%$ \\
\hline & 21 a 30 anos & $33 \%$ & $23 \%$ & $32 \%$ \\
\hline & Mais de 30 anos & $39 \%$ & $45 \%$ & $40 \%$ \\
\hline \multirow{6}{*}{ FUNÇÃO } & Função & & & \\
\hline & Administrativa & $15 \%$ & $14 \%$ & $15 \%$ \\
\hline & Função Técnica & $18 \%$ & $23 \%$ & $19 \%$ \\
\hline & Gestor & $8 \%$ & $14 \%$ & $9 \%$ \\
\hline & Pesquisador & $20 \%$ & $14 \%$ & $19 \%$ \\
\hline & Tecnologista & $39 \%$ & $36 \%$ & $39 \%$ \\
\hline \multirow{6}{*}{$\begin{array}{c}\text { GRAU DE } \\
\text { ESCOLARIDADE }\end{array}$} & Doutorado & $38 \%$ & $18 \%$ & $35 \%$ \\
\hline & Graduação & $26 \%$ & $32 \%$ & $26 \%$ \\
\hline & Médio & $3 \%$ & $0 \%$ & $2 \%$ \\
\hline & Mestrado & $17 \%$ & $27 \%$ & $19 \%$ \\
\hline & Pós Doutorado & $10 \%$ & $9 \%$ & $10 \%$ \\
\hline & Pós Graduação & $7 \%$ & $14 \%$ & $8 \%$ \\
\hline
\end{tabular}

Comparando o cluster 1 com o cluster 2, observa-se algumas variações mais significativas em termos proporcionais:

a quantidade de respondentes do sexo masculino foi maior no cluster 2;

a quantidade de respondentes entre 26 e 35 anos foi maior no cluster 2;

a quantidade de respondentes que têm entre 21 e 30 anos de instituição foi menor no cluster 2;

a quantidade de gestores foi maior no cluster 2; 
houve uma variação muito grande entre o grau de escolaridade entre os respondentes do cluster 1 e do cluster 2 . Observa-se que no cluster 2 existe um número menor de doutores e pós-doutores, porém há um aumento no número de mestres, graduados e pós-graduados.

Com base nas comparações acima, verifica-se que no cluster 2 há mais pessoas com idade entre 26 e 35 anos., com nível de escolaridade entre mestres e pós-graduados, mais gestores, mais homens e com tempo de casa entre 21 e 30 anos.

Outro teste realizado para analisar as discrepâncias entre os valores observados para os dois clusters foi a análise de variância (ANOVA). Nessa análise verificou-se a significância estatística das diferenças entre as médias das respostas dadas a todos os itens cujos resultados estão na TAB.5.29. Nenhum item apresenta diferença estatística significante.

Com base nas análises, pode-se argumentar que a responsabilidade social do cluster 1 é semelhante à do cluster 2, como indica a TAB.5.29, que foi gerada com base no software SPSS.

TABELA 5.29 - Análise de variância (ANOVA) para dois clusters

\begin{tabular}{lccccc}
\hline & \multicolumn{2}{c}{ Média } & F & $\boldsymbol{\alpha}$ & S/NS \\
& Cluster 1 & Cluster 2 & & & \\
\hline Cliente & 3,7208 & 4,1000 & 1,366 &, 244 & NS \\
Comunidade & 2,2943 & 2,1429 &, 395 &, 530 & NS \\
Fornecedor & 1,8775 & 1,9091 &, 016 &, 900 & NS \\
Governo e Sociedade & 2,5403 & 2,5795 &, 024 &, 877 & NS \\
Meio Ambiente & 3,3535 & 3,6061 &, 976 &, 325 & NS \\
Público Interno & 4,1552 & 4,3011 &, 505 &, 478 & NS \\
\hline Responsabilidade Social & 2,5631 & 2,6627 &, 389 &, 534 & NS \\
\hline
\end{tabular}


Finalizadas as apresentações e interpretações dos resultados desse estudo, o próximo capítulo apresentará as conclusões finais acerca do trabalho e as implicações de seus resultados, além de apontar suas limitações e promover sugestões para aprofundar os temas abordados em estudos futuros. 


\section{CONCLUSÕES}

Neste capítulo são apresentadas as conclusões geradas pela discussão dos resultados, as implicações acadêmicas e gerenciais do estudo, bem como suas limitações. Também sugestões para futuras investigações relacionadas com o tema serão dadas.

\subsection{Conclusões do estudo e implicações acadêmicas}

O objetivo do estudo foi propor e testar um modelo teórico multidimensional para analisar a responsabilidade social do IPEN. Para tal, o ponto de partida foi uma revisão crítica da literatura sobre o tema seguido da elaboração de uma proposição de um modelo conceitual. Esse modelo foi testado e validado com base em análises estatísticas uni e multivariadas dos dados colhidos junto aos 171 funcionários do IPEN e atingiu com êxito o seu propósito.

A revisão bibliográfica sobre a responsabilidade social mostrou que esse conceito evoluiu e tem sido cada vez mais acolhido pelas organizações empresariais e institucionais. Mostrou também que existem abordagens diferentes por autores diversos, revelando a inexistência de uma definição consensual para o constructo responsabilidade social. O conceito multidimensional da responsabilidade social utilizado como base para a construção do modelo teórico testado foi então proposto nesse trabalho e inclui as dimensões: público interno, meio ambiente, fornecedor, cliente, comunidade e governo/sociedade. Esse modelo foi submetido a um pré-teste cujos resultados ajudaram a desenvolver e refinar o modelo conceitual, as hipóteses de pesquisa e as escalas de mensuração, que foram novamente testados e refinados na etapa descritiva conclusiva do trabalho de campo.

Diversos modelos teóricos foram encontrados na literatura para medir ou explicar a responsabilidade social de uma organização. O modelo teórico apresentado teve como base a pesquisa bibliográfica realizada, associada a algumas reflexões próprias, mas com forte embasamento no trabalho efetuado 
pelo Instituto Ethos de Responsabilidade Social e pela United Nations Departament of Economic and Social Affairs.

Além da proposição de um modelo teórico simplificado e completo, outra importante contribuição acadêmica do estudo foi a construção de um modelo do tipo reflexivo-formativo, no qual o constructo responsabilidade social é formativo de $2^{\mathrm{a}}$ ordem, constituído pelos constructos de $1^{\mathrm{a}}$ ordem público interno, meio ambiente, fornecedores, clientes, comunidade e governo/sociedade. Esses, por sua vez são mensurados por itens reflexivos, desenvolvidos a partir de escalas já existentes e testadas na literatura, com adaptações inspiradas no pré-teste.

Após as etapas exploratórias da revisão da literatura e com a decorrente proposição do modelo teórico de responsabilidade social, o objetivo principal foi alcançado por meio da pesquisa quantitativa com os 171 funcionários do IPEN. Com relação ao perfil da amostra, verificou-se que a maioria dos aspectos está em concordância com o que era esperado, como, por exemplo, a divisão da amostra por sexo (66 \% homens e $34 \%$ mulheres), grau de instrução (80\% no mínimo graduados), idade (83 \% acima de 46 anos), locação no instituro (65\% está em um dos centros de pesquisa), tempo de trabalho (72 \% com mais de 20 anos de instituto) e função dos respondentes (77 \% de técnicos, pesquisadores ou tecnologistas).

O perfil dos respondentes revela que são pessoas maduras, com longo tempo de instituição, em cargos técnicos e de pesquisa, com alto grau de escolaridade e atuam nos centros de pesquisa do IPEN.

O modelo teórico proposto mostrou robustez em face dos testes de confiabilidade e validade realizados, tanto no nível dos itens de mensuração quanto do modelo estrutural, além de apresentar um bom nível de ajuste geral ou explicação de variância $\left(R^{2}=0,878\right)$. Todas as relações hipotéticas presentes no modelo foram confirmadas pelos resultados empíricos.

Em termos das relações entre as variáveis observáveis e os constructos latentes, observa-se que:

a.) o IPEN evidencia esforços e atitudes que são comprometidas com o bem-estar dos seus trabalhadores (público interno) em sentido amplo. Também reconhece o valor de seus funcionários e, principalmente, assume a obrigação ética de combater todas as formas de 
discriminação, aproveitando, dessa maneira, as oportunidades ofererecidas pela diversidade da riqueza étnica e cultural de cada um.

b.) o relacionamento do IPEN com seus clientes inspira credibilidade e confiança, revela uma cultura de respeito e valorização perante seus consumidores.

c.) de maneira moderada, o IPEN investiga e controla os possíveis impactos ambientais causados por suas atividades produtivas. O IPEN foca suas ações preventivas nos processos que oferecem danos ponteciais à saúde e à segurança de seus trabalhadores e da população do entorno. Além disso, o IPEN cumpre suas obrigações legais e utiliza de forma consciente e racional os recursos naturais e materiais envolvidos diretamente na execução de suas atividades. O IPEN não possui programas estruturados de educação ambiental e/ou não divulga adequadamente estas informações a seus funcionários.

d.) o IPEN atua de maneira moderada, diante de ações relacionadas ao governo e sociedade, atuando de forma comprometida e atendendo aos requisitos legais e os que regulam o funcionamento das instalações nucleares. Porém, a participação do IPEN em associações e fóruns, sua contribuição com recursos para programas sociais, suas propostas de intesesse público e de caráter social são insipientes.

e.) um relacionamento comunitário como a filantropia é um fator importante como parte das ações para promover a justiça social, porém, tem seu poder limitado pois apenas ameniza os sintomas. É preciso identificar e reconhecer os aspectos sociais que envolvem a comunidade, avaliar o tipo e magnitude das ações, estabelecer e gerenciar planos de ação que promovam a melhoria contínua. O IPEN não possui, ou pelo menos não foram identificadas pelos seus funcionários, ações dessa magnitude que beneficiem a sua comunidade. 
f.) o IPEN apresenta uma fraca relação com seus fornecedores. $O$ fato da política do Instituto focar apenas no menor preço ocasiona a perda de exelentes oportunidades de auxiliar cominidades próximas, incentivar fornecedores menores, auditar e incentivar a responsabilidade social dos fornecedores e ainda estabelecer uma parceria duradoura e comprometida.

Todos os resultados dos testes realizados apontaram para a importância de considerar em conjunto todas as dimensões da responsabilidade social. Se não forem considerados todos os aspectos levantados nesse trabalho, pode-se correr o risco de negligenciar pontos muito importantes da responsabilidade social.

\subsection{Implicações gerenciais}

Além das contribuições acadêmicas do estudo, o modelo proposto e validado pode ser utilizado pelo IPEN como uma ferramenta para gerenciar sua responsabilidade social.

Este trabalho proporcionou uma profunda compreensão acerca do conceito de responsabilidade social e dos fatores que influenciam a percepção das pessoas envolvidas na pesquisa. Esse conhecimento, aliado a um modelo robusto que permitiu mensurar as diferentes dimensões da responsabilidade social, são importantes instrumentos para a prática gerencial do IPEN. Com base nos elementos que mais influenciam a forma como os funcionários entendem e definem a responsabilidade social do IPEN, pode-se encontrar maneiras de atuar de forma mais relevante e estabelecer planos sustentáveis para que essa atuação seja efetiva.

Assim, as sugestões do estudo para os gestores do IPEN são as seguintes:

a.) compreender o que envolve a responsabilidade social ajudará a instituição a planejar estratégias e táticas para implantação de um programa completo que possa abranger todas as dimensões da responsabilidade social, permitindo que 0 instituto atue de forma consistente em todas as suas áreas e que isto se torne visível por todos os seus publicos e partes interessadas;

b.) conhecer a visão dos funcionários a respeito da responsabilidade social do IPEN diante de suas dimensões possibilitará aos gestores focar suas 
ações em propósitos que beneficiem pontos fracos da instituição que necessitam de maior atenção;

c.) ações de comunicação e marketing deverão ser aprimoradas, pois não refletem para o público em geral os benefícios que contribuem para a responsabilidade social oferecidos pela instituição.

\subsection{Limitações do estudo}

O estudo apresentado teve como objetivo principal contribuir para a compreensão da responsabilidade social do IPEN a partir da proposição de um modelo teórico para analisar as múltiplas dimensões da responsabilidade social. Nesse sentido, a pesquisa de campo realizada alcançou os objetivos inicialmente estabelecidos, ajudando a refinar e confirmar o modelo proposto. É importante, contudo, reconhecer que qualquer abordagem de pesquisa possui uma série de limitações que estão descritas a seguir.

A primeira diz respeito ao método de seleção dos respondentes para gerar a amostra nas análises quantitativas. Por ser de natureza não aleatória, com respostas voluntárias de seus funcionários, a amostra não permite generalizações dos resultados obtidos. Portanto, os achados da pesquisa de campo devem, a rigor, ficar restritos ao âmbito da própria amostra.

Além disso, a utilização da internet como forma de aplicação do questionário pode ter limitado o acesso à pesquisa, pois há pessoas que não se sentem confortáveis com o meio eletrônico.

Em termos do processo de análise do modelo, a principal limitação do estudo foi a impossibilidade de verificar o impacto da dimensão ética sobre a responsabilidade social. Essa dimensão foi retirada do modelo por não apresentar índices de confiabilidade adequados. Uma possível explicação para esse problema deriva do fato dos funcionários do IPEN terem certo desconhecimento dos temas abordados. A escala de mensuração para ética, apesar de ser considerada adequada para inclusão no modelo teórico, apresentou um Alfa de Cronbach próximo ao valor limítrofe, recomendando-se, portanto, um trabalho de revisão dos ítens para usos futuros.

Apesar das limitações, acredita-se que os conhecimentos obtidos com 0 estudo realizado são de grande valia, não apenas em termos acadêmicos, mas para auxiliar o IPEN a programar, manter e melhorar a qualidade das ações e 
práticas de cunho social, não só no local de trabalho, mas também em todas as esferas sobre as quais exerça alguma influência.

Apesar do modelo ter integrado constribuições de diferentes autores, incorporado os resultados da pesquisa quantitativa e reflexões críticas sobre os conceitos associados à responsabilidade social, certamente novos constructos poderão surgir. Além disso, novas abordagens metodológicas poderão ou não confirmar os resultados obtidos nessa dissertação.

\subsection{Sugestões para trabalhos futuros}

A investigação sobre o constructo responsabilidade social do IPEN não se esgota nesse estudo. Fundações e instituições de todo o mundo estudam maneiras de mostrar às empresas que não basta realizar ações sociais de forma isolada, mas integrá-las aos sistemas de planejamento, avaliação, monitoramento e em seus processos de gestão (MENDONÇA, 2003).

Visto que o estudo realizado focou exclusivamente nos funcionários do IPEN, seria interessante replicá-lo com os seus parceiros, tais como: funcionários terceirizados, alunos, fornecedores, clientes e membros da comunidade do entorno para investigar se os resultados são compatíveis com os aqui obtidos. Isso possibilitaria verificar se os resultados do presente estudo estão atrelados somente aos funcionários do IPEN ou se podem ser interpretados de forma geral.. Seria de grande valia para o IPEN visualizar seu posicionamento frente às dimensões da responsabilidade social sob a ótica de diferentes públicos e compará-las entre si.

Especificamente, quanto aos resultados das análises do modelo conceitual, sugere-se desenvolver novos itens de mensuração para o constructo ética, que não revelaram níveis de correlação e confiabilidade aceitáveis. Isso permitiria não apenas testar novamente o modelo para verificar se houve alguma mudança significativa, como também enriquecer o conhecimento teórico sobre a responsabilidade social.

Outra sugestão para dar continuidade a esse estudo é o desenvolvimento de uma metodologia de implantação de ações de responsabilidade social no IPEN. Com base nos resultados do presente estudo, seria possível identificar os pontos fortes que devem ser incentivados, os pontos fracos a serem aprimorados e os novos pontos a serem implementados. Com base nesses pontos, o IPEN 
poderá elaborar uma metodologia de implantação focada na sustentabilidade e na continuidade das ações que contribuam com a sua responsabilidade social. A implementação de novas ações de responsabilidade social em conjunto com aquelas já existentes possibilitará estabelecer uma relação de ganhos entre a Instituição e o ambiente que a cerca. $O$ estabelecimento das ações de responsabilidade social no IPEN de forma estruturada e contínua garantirá a promoção de sua sustentabilidade e beneficiará a população como um todo. 


\section{Responsabilidade Social}

Prezado(a) amigo(a),

Meu nome é Rita de Cássia Mutarelli, sou aluna de mestrado no IPEN sob a orientação da Dra. Gaianê Sabundjian. Estou enviando um questionário que faz parte da minha dissertação.

O presente questionário tem como objetivo pesquisar o IPEN no que se refere as práticas de açôes de responsabilidade social. Convém ressaltar que a direção da casa apenas disponibilizou a ferramenta, sem nenhum outro envolvimento.

O preenchimento deste questionário irá contribuir para identificar sua posição atual e com isto identificar as principais áreas para seu aprimoramento. São 35 questôes e não levará mais que 10 minutos para o seu preenchimento.

Por favor, clique no link abaixo para iniciar o preenchimento. Desde já agradeço muito sua atenção e sua colaboração.

Rita de Cássia Mutarelli.

IPEN - INSTITUTO DE PESQUISAS ENERGÉTICAS E NUCELARES.

Av. Prof. Lineu Prestes, 2.242, Cidade Universitária, São Paulo-SP.

e-mail: rmutarelli@gmail.com

Tel. $\quad+55(11) 3133-9492$

${ }^{*}$ Required

\section{Perfil do Entrevistado}

A seguir são solicitadas informações específicas sobre o entrevistado.

\section{Qual é o Centro que você trabalha? *}

Quantos anos você trabalha nesta instituição? *

\section{Qual sua idade?*}

\section{Sexo *}

Masculino

Feminino 
Qual é o seu grau de escolaridade?*

Preencha o grau de escolaridade que você tenha de fato concluído

Fundamental

Médio

Graduação

Pós Graduação

Mestrado

Doutorado

Pós Doutorado

Qual sua função no IPEN? *

Responda a alternativa que mais se aproxima com sua função

Aluno

Função Administrativa

Função Técnica

Pesquisador

Tecnologista

Gestor

Continue $\$$

$12 \%$ completed

\section{Responsabilidade Social}

${ }^{*}$ Required

\section{Valores, Transparência e Governança}

A seguir são apresentadas afirmações sobre valores, transparência e governança com relação ao IPEN. Você deverá responder considerando sua percepção quanto as afirmativas marcando o número que corresponda ao seu grau de concordância / conhecimento.

1 - O Instituto possui um documento escrito que explica quais são os compromissos da instituição com seus profissionais e com a sociedade. *

Responda o grau de conhecimento que você possui deste documento.

$$
\begin{array}{llllll}
1 & 2 & 3 & 4 & 5 & 6
\end{array}
$$

Desconheço $\bigcirc \bigcirc \bigcirc \bigcirc \bigcirc$ Conheço 
2 - O Instituto publica periodicamente um documento chamado "Balanço Social" . * Responda o grau de conhecimento que você possui desta publicação.

$\begin{array}{llllll}1 & 2 & 3 & 4 & 5 & 6\end{array}$

Desconheço $\bigcirc \bigcirc \bigcirc \bigcirc \bigcirc$ Conheço

3 - O Instituto possui separação clara entre a comercialização de seus produtos e a pesquisa acadêmica.

Responda com seu grau de concordância com relação a esta afirmação.

$\begin{array}{llllll}1 & 2 & 3 & 4 & 5 & 6\end{array}$

Discordo $\bigcirc 0.0$ Concordo

4 - O Instituto estabelece, implementa e mantém um "Sistema de Gestão de Qualidade". * Responda com seu grau de concordância com relação a esta afirmação.

$\begin{array}{llllll}1 & 2 & 3 & 4 & 5 & 6\end{array}$

Discordo $\bigcirc \bigcirc \bigcirc \bigcirc \bigcirc$ Concordo

«Back Continue *

$25 \%$ completed

\section{Responsabilidade Social}

${ }^{*}$ Required

\section{Público Interno}

A seguir são apresentadas afirmações sobre a atuação do IPEN junto ao público interno. Você deverá responder considerando sua percepção quanto as afirmativas marcando o número que corresponda ao seu grau de concordância / conhecimento.

5 - Além de cumprir com as obrigações determinadas por lei, o Instituto se preocupa em oferecer a seus funcionários um ambiente físico agradável e seguro. Busca incentivar os cuidados com a saúde e esta aberto a críticas e sugestôes relativas a estes aspectos. * Responda com seu grau de concordância com relação a esta afirmação.

$$
\begin{array}{llllll}
1 & 2 & 3 & 4 & 5 & 6
\end{array}
$$

Discordo $\bigcirc \bigcirc \bigcirc \bigcirc \bigcirc$ Concordo 
6 - $O$ Instituto oferece benefícios adicionais (além daqueles exigidos por lei) aos seus funcionários e aos seus dependentes. *

Responda com seu grau de concordância com relação a esta afirmação.

$\begin{array}{llllll}1 & 2 & 3 & 4 & 5 & 6\end{array}$

Discordo $\bigcirc \bigcirc \bigcirc \bigcirc \bigcirc$ Concordo

7 - Na contratação de funcionários, o Instituto divulga os critérios que vai utilizar na seleção dos candidatos (como escolaridade, tempo de experiência e conhecimento exigido). Responda com seu grau de concordância com relação a esta afirmação.

$\begin{array}{llllll}1 & 2 & 3 & 4 & 5 & 6\end{array}$

Discordo $\bigcirc \bigcirc \bigcirc \bigcirc$ Concordo

8 - Os critérios utilizados na seleção de pessoal, são isentos de práticas discriminatórias em relação a gênero, raça, orientação sexual, idade e crenças religiosas ou políticas dos candidatos, bem como pessoas com deficiência. *

Responda com seu grau de concordância com relação a esta afirmação.

$$
\begin{array}{llllll}
1 & 2 & 3 & 4 & 5 & 6
\end{array}
$$

\section{Discordo $\bigcirc \bigcirc \bigcirc \bigcirc \bigcirc$ Concordo}

9 - As dependências do Instituto contam com recursos para facilitar o deslocamento e a convivência de pessoas com deficiência motora, auditiva ou visual (como rampas, avisos de segurança em braile, sinais luminosos e sonoros em áreas de circulação, etc.) *

Responda com seu grau de concordância com relação a esta afirmação.

$$
\begin{array}{llllll}
1 & 2 & 3 & 4 & 5 & 6
\end{array}
$$

Discordo $\bigcirc \bigcirc \bigcirc \bigcirc \bigcirc$ Concordo

10 - O Instituto entende que é direito do funcionário participar de sindicatos e associações de classe. Permite que representantes sindicais compareçam ao Instituto para discutir questões referentes aos interesses dos funcionários.

Responda com seu grau de concordância com relação a esta afirmação.

$\begin{array}{llllll}1 & 2 & 3 & 4 & 5 & 6\end{array}$

Discordo $\bigcirc \bigcirc \bigcirc \bigcirc$ Concordo 
11 - O Instituto valoriza e incentiva o desenvolvimento profissional de seus funcionários. * Responda com seu grau de concordância com relação a esta afirmação.

$$
\begin{array}{llllll}
1 & 2 & 3 & 4 & 5 & 6
\end{array}
$$

\section{Discordo $\bigcirc \bigcirc \bigcirc \bigcirc \bigcirc$ Concordo}

12 - O Instituto facilita o acesso à informação como forma de desenvolvimento pessoal e profissional de seus funcionários. *

Responda com seu grau de concordância com relação a esta afirmação.

$$
\begin{array}{llllll}
1 & 2 & 3 & 4 & 5 & 6
\end{array}
$$

Discordo $\bigcirc \bigcirc \bigcirc \bigcirc \bigcirc$ Concordo

«Back Continue »

\section{Responsabilidade Social}

${ }^{*}$ Required

\section{Meio Ambiente}

A seguir são apresentadas afirmaçôes sobre os cuidados com meio ambiente dentro do IPEN. Você deverá responder considerando sua percepção quanto as afirmativas marcando o número que corresponda ao seu grau de concordância / conhecimento.

13 - O Instituto conhece, entende e avalia os impactos de suas atividades sobre o meio ambiente (como rejeitos radioativos, emissão de poluentes, erosão do solo, alto consumo de energia, de água, de combustível, etc.).

Responda com seu grau de concordância com relação a esta afirmação.

$$
\begin{array}{llllll}
1 & 2 & 3 & 4 & 5 & 6
\end{array}
$$

\section{Discordo $\bigcirc \bigcirc \bigcirc \bigcirc \bigcirc$ Concordo}

14 - O Instituto procura implementar em suas dependências e em suas atividades, ações que visam preservar o meio ambiente, como por exemplo: coleta seletiva, economia no consumo de papel, redução no consumo de energia e água, orientação da política de compras para priorizar fornecedores que não prejudiquem o meio ambiente, destinação final adequada para resíduos que necessitem de tratamento específico, etc. "

Responda com seu grau de concordância com relação a esta afirmação.

$$
\begin{array}{llllll}
1 & 2 & 3 & 4 & 5 & 6
\end{array}
$$

Discordo $\bigcirc \bigcirc \bigcirc \bigcirc \bigcirc$ Concordo 
15 - Uma forma efetiva de reduzir os impactos ambientais é promovendo a educação ambiental para os funcionários, seus familiares e para a comunidade. $O$ Instituto promove estas ações.

Responda com seu grau de concordância com relação a esta afirmação.

$$
\begin{array}{llllll}
1 & 2 & 3 & 4 & 5 & 6
\end{array}
$$

Discordo $\bigcirc \bigcirc \bigcirc \bigcirc$ Concordo

«Back Continue »

$50 \%$ completed

\section{Responsabilidade Social}

${ }^{*}$ Required

\section{Fornecedores}

A seguir são apresentadas afirmações sobre a atuação dos fornecedores e sua responsabilidade social com relação ao IPEN e a sociedade. Você deverá responder considerando sua percepção quanto as afirmativas marcando o número que corresponda ao seu grau de concordância / conhecimento.

16 - Para contratar um fornecedor, além de exigir uma boa proposta comercial (com qualidade, preço e prazo), o Instituto avalia se ele mantém práticas de responsabilidade social. *

Responda com seu grau de conhecimento / concordância com relação a esta afirmação.

$\begin{array}{llllll}1 & 2 & 3 & 4 & 5 & 6\end{array}$

Desconheço $\bigcirc \bigcirc \bigcirc \bigcirc \bigcirc$ Conheço

17 - O Instituto verifica constantemente as condiçôes proporcionadas por seus fornecedores aos próprios empregados. *

Responda com seu grau de conhecimento / concordância com relação a esta afirmação.

$\begin{array}{llllll}1 & 2 & 3 & 4 & 5 & 6\end{array}$

Desconheço $\bigcirc \bigcirc \bigcirc \bigcirc \bigcirc$ Conheço

18 - O Instituto procura, sempre que possivel, orientar os fornecedores a seguir seus princípios de responsabilidade social e se dispõe a ajuda-los na sua implantação. * Responda com seu grau de conhecimento / concordância com relação a esta afirmação.

$\begin{array}{llllll}1 & 2 & 3 & 4 & 5 & 6\end{array}$

Desconheço $\bigcirc \bigcirc \bigcirc \bigcirc \bigcirc$ Conheço 
19 - O Instituto busca fornecedores em cooperativas de pequenos produtores, associações de bairro e projetos de geração de renda (como cooperativas, incubadoras de negócios, outras micro e pequenas empresas, etc.). *

Responda com seu grau de conhecimento / concordância com relação a esta afirmação.

$\begin{array}{llllll}1 & 2 & 3 & 4 & 5 & 6\end{array}$

Desconheço $\bigcirc \bigcirc \bigcirc \bigcirc$ Conheço

«Back Continue »

$62 \%$ completed

\section{Responsabilidade Social}

${ }^{*}$ Required

\section{Clientes}

A seguir são apresentadas afirmações sobre a atuação do IPEN com relação aos seus clientes. Você deverá responder considerando sua percepção quanto as afirmativas marcando o número que corresponda ao seu grau de concordância / conhecimento.

20 - O Instituto tem um canal formal de comunicação com seus clientes (como espaço para sugestões, central de atendimento on line, número de telefone, e-mail de quem possa atende-lo e resolver dúvidas ou problemas).

Responda com seu grau de conhecimento / concordância com relação a esta afirmação.

$$
\begin{array}{llllll}
1 & 2 & 3 & 4 & 5 & 6
\end{array}
$$

Desconheço $\bigcirc \bigcirc \bigcirc \bigcirc \bigcirc$ Conheço

21 - O Instituto analisa dúvidas, sugestôes e reclamaçóes recebidas e as utiliza como instrumento para aperfeiçoar suas atividades.

Responda com seu grau de conhecimento / concordância com relação a esta afirmação.

$\begin{array}{llllll}1 & 2 & 3 & 4 & 5 & 6\end{array}$

Desconheço $\bigcirc \bigcirc \bigcirc \bigcirc \bigcirc$ Conheço

22 - O Instituto realiza pesquisa de satisfação com seus clientes para, com base nos resultados, programar melhorias em seus produtos e serviços. "

Responda com seu grau de conhecimento / concordância com relação a esta afirmação.

$\begin{array}{llllll}1 & 2 & 3 & 4 & 5 & 6\end{array}$

Desconheço $\bigcirc \bigcirc \bigcirc \bigcirc$ Conheço 
23 - Em sua comunicação (contratos, páginas da internet e mensagens publicitárias) o Instituto não utiliza conteúdo enganoso ou que induza seus clientes a erros de entendimento. *

Responda com seu grau de conhecimento / concordância com relação a esta afirmação.

$\begin{array}{llllll}1 & 2 & 3 & 4 & 5 & 6\end{array}$

Desconheço $\bigcirc 000$ Conheço

24 - $\mathrm{O}$ instituto pesquisa e divulga os riscos que seus produtos e serviços podem causar à saúde ou à segurança de seus clientes. *

Responda com seu grau de conhecimento / concordância com relação a esta afirmação.

$\begin{array}{llllll}1 & 2 & 3 & 4 & 5 & 6\end{array}$

Desconheço $\bigcirc \bigcirc \bigcirc \bigcirc \bigcirc$ Conheço

«Back Continue »

$75 \%$ completed

\section{Responsabilidade Social}

${ }^{*}$ Required

\section{Comunidade}

A seguir são apresentadas afirmações sobre a atuação do IPEN junto a comunidade. Você deverá responder considerando sua percepção quanto as afirmativas marcando o número que corresponda ao seu grau de concordância / conhecimento.

25 - O Instituto se preocupa em estar sempre em contato com a comunidade de entorno, procurando minimizar os impactos negativos que suas atividades possam causar. * Responda com seu grau de concordância com relação a esta afirmação.

$$
\begin{array}{llllll}
1 & 2 & 3 & 4 & 5 & 6
\end{array}
$$

Discordo $\bigcirc \bigcirc \bigcirc \bigcirc \bigcirc$ Concordo

26 - Sabendo que, a prosperidade e a situação da comunidade local podem refletir diretamente no sucesso do negócio, o Instituto tem práticas de gestão que beneficiam o desenvolvimento local. *

Responda com seu grau de concordância com relação a esta afirmação.

$$
\begin{array}{llllll}
1 & 2 & 3 & 4 & 5 & 6
\end{array}
$$

Discrodo $\bigcirc \bigcirc \bigcirc \bigcirc$ Concordo 
27 - O instituto incentiva o trabalho voluntário de seus funcionários na comunidade. *

Responda com seu grau de concordância com relação a esta afirmação.

$$
\begin{array}{llllll}
1 & 2 & 3 & 4 & 5 & 6
\end{array}
$$

Discordo $\bigcirc \bigcirc \bigcirc \bigcirc$ Concordo

28 - $\mathrm{O}$ instituto "adotou" pelo menos uma entidade de sua comunidade e mobiliza sua rede de contatos a favor dela.

Responda com seu grau de concordância com relação a esta afirmação.

$$
\begin{array}{llllll}
1 & 2 & 3 & 4 & 5 & 6
\end{array}
$$

Discordo $\bigcirc \bigcirc \bigcirc \bigcirc \bigcirc$ Concordo

29 - Existe entre o Instituto e a(s) entidade(s) por ele beneficiada(s) uma conversa franca sobre o papel de cada um deles na parceria. *

Responda com seu grau de concordância com relação a esta afirmação.

$$
\begin{array}{llllll}
1 & 2 & 3 & 4 & 5 & 6
\end{array}
$$

\section{Discordo $\bigcirc \bigcirc \bigcirc \bigcirc \bigcirc$ Concordo}

30 - A responsabilidade social deve ser uma forma de gestão do negócio. Ao optar por apoiar determinada entidade ou projeto, o Instituto busca de algum modo conciliar seus interesses com os dessa entidade ou projeto.

Responda com seu grau de concordância com relação a esta afirmação.

$$
\begin{array}{llllll}
1 & 2 & 3 & 4 & 5 & 6
\end{array}
$$

\section{Discordo $\bigcirc \bigcirc \bigcirc \bigcirc \bigcirc$ Concordo}

31 - $O$ instituto acredita que um dos fatores para o bom andamento de suas atividades se deve as suas ações sociais junto a comunidade. *

Responda com seu grau de concordância com relação a esta afirmação.

$\begin{array}{llllll}1 & 2 & 3 & 4 & 5 & 6\end{array}$

Discordo $\bigcirc \bigcirc \bigcirc \bigcirc$ Concordo




\section{Responsabilidade Social}

${ }^{*}$ Required

\section{Governo e Sociedade}

A seguir são apresentadas afirmações sobre as ações do IPEN junto ao governo e sociedade. Você deverá responder considerando sua percepção quanto as afirmativas marcando o número que corresponda ao seu grau de concordância / conhecimento.

32 - O Instituto discute com outros Institutos suas necessidades e formas de mobilização em busca de melhores condições tanto para o próprio Instituto quanto para a sociedade.

Responda com seu grau de concordância com relação a esta afirmação.

$$
\begin{array}{llllll}
1 & 2 & 3 & 4 & 5 & 6
\end{array}
$$

Discordo $\bigcirc \bigcirc \bigcirc \bigcirc \bigcirc$ Concordo

33 - O Instituto é criterioso sobre seu envolvimento em campanhas políticas.

Responda com seu grau de concordância com relação a esta afirmação,

$\begin{array}{llllll}1 & 2 & 3 & 4 & 5 & 6\end{array}$

Discordo $\bigcirc \bigcirc \bigcirc \bigcirc \bigcirc$ Concordo

34 - O instituto informa seus funcionários sobre a importância de participar das administrações públicas ( opinando, por exemplo, no orçamento participativo, nas eleições de conselhos municipais, em consultas públicas, etc.).

Responda com seu grau de concordância com relação a esta afirmação.

$\begin{array}{llllll}1 & 2 & 3 & 4 & 5 & 6\end{array}$

Discordo $\bigcirc \bigcirc \bigcirc \bigcirc$ Concordo

35 - 0 instituto colabora com a melhoria dos espaços públicos de sua região (como escolas, postos de saúde, praças, áreas verdes, grêmios, etc.).

Responda com seu grau de concordância com relação a esta afirmação.

$\begin{array}{llllll}1 & 2 & 3 & 4 & 5 & 6\end{array}$

Discordo $\bigcirc \bigcirc \bigcirc \bigcirc \bigcirc$ Concordo 
Escreva suas observações com relação ao questionário

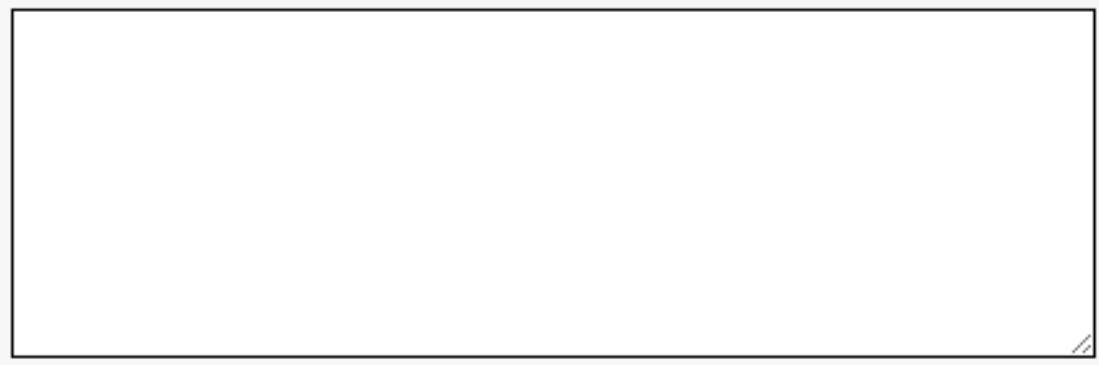

« Back Submit

Never submit passwords through Google Forms.

100\%: You made it.

\section{Responsabilidade Social}

Muito obrigada pela sua colaboração

Coloco-me a sua disposição para qualquer esclarecimento adicional no email rmutarelli@gmail.com. 


\begin{tabular}{|c|c|c|}
\hline COD. & INDICADOR & DIMENSÃO \\
\hline$A 1$ & Compromissos éticos & \multirow{4}{*}{ ÉTICA } \\
\hline A2 & Balanço social & \\
\hline A3 & Governança corporativa & \\
\hline A4 & Garantia da qualidade & \\
\hline B5 & Cuidados com saúde segurança e condições de trabalho & \multirow{8}{*}{ PÚBLICO INTERNO } \\
\hline B6 & Beneficios adicionais & \\
\hline B7 & Critérios de contratação & \\
\hline B8 & Valorização da diversidade e promoção da equidade & \\
\hline B9 & Inclusão de pessoas com deficiência & \\
\hline B10 & Relações com sindicato & \\
\hline B11 & Compromisso com o desenvolvimento profissional e empregabilidade & \\
\hline $\mathrm{B} 12$ & Acesso à informação & \\
\hline $\mathrm{C} 13$ & Gerenciamento dos impactos sobre o meio ambiente e do ciclo de vida de & \multirow{3}{*}{ MEIO AMBIENTE } \\
\hline C14 & Comprometimento do instituto com a melhoria da qualidade ambiental & \\
\hline $\mathrm{C} 15$ & Educação e conscientização ambiental & \\
\hline $\mathrm{D} 16$ & Critérios de seleção e avaliação dos fornecedores & \multirow{4}{*}{ FORNECEDORES } \\
\hline D17 & Empregados dos fornecedores & \\
\hline D18 & Responsabilidade social dos fornecedores & \\
\hline D19 & Apoio ao desenvolvimento dos fornecedores & \\
\hline E20 & Excelência de atendimento & \multirow{5}{*}{ CLIENTES } \\
\hline E21 & Dúvidas, sugestões e reclamações & \\
\hline E22 & Satisfação dos consumidores / clientes & \\
\hline E23 & Política de comunicação comercial & \\
\hline E24 & Conhecimento e gerenciamento dos danos potenciais dos produtos e servicos & \\
\hline $\mathrm{F} 25$ & Gerenciamento do impacto da empresa na comunidade do entorno & \multirow{7}{*}{ COMUNIDADE } \\
\hline F26 & Relacionamento com a comunidade do entorno & \\
\hline F27 & Estímulo ao trabalho voluntário & \\
\hline F28 & Envolvimento da empresa em ação social & \\
\hline F29 & Relações com entidades beneficiadas & \\
\hline F30 & Participação comunitária & \\
\hline F31 & Benefícios para o negócio & \\
\hline G32 & Participação e influência sindical & \multirow{4}{*}{ GOVERNO E SOCIEDADE } \\
\hline G33 & Envolvimento em campanhas políticas & \\
\hline G34 & Participação e acompanhamento das administrações públicas & \\
\hline G35 & Melhorias nos espacos públicos e apoio a iniciativas sociais governamentais & \\
\hline
\end{tabular}


ANEXO A - Normas de todos os grupos vigentes na CNEN

TABELA A.1 - Grupo 1 - Instalações Nucleares

\section{Grupo 1 - Instalações Nucleares}

Res 109/11 Licenciamento de Operadores de Reatores Nucleares

NE 1.02 Critérios Gerais de Projeto para Usinas de Reprocessamento de Combustíveis Nucleares

NE 1.04 Licenciamento de Instalações Nucleares

Posições Regulatórias

1.04 / 001 - Apresentação de Relatórios de Segurança para Instalações de Enriquecimento Isotópico por Ultracentrifugação

NE 1.06 Requisitos de Saúde para Operadores de Reatores Nucleares

NE 1.08 Modelo Padrão para Relatório de Análise de Segurança de Usinas de Reprocessamento de Combustíveis Nucleares

NE 1.09 Modelo Padrão para Relatório de Análise de Segurança de Fábricas de Elementos Combustíveis

NE 1.10 Segurança de Sistemas de Barragem de Rejeitos Contendo Radionuclídeos

NE 1.11 Modelo Padrão para Relatório de Análise de Segurança de Usinas de Produção de Hexafluoreto de Urânio Natural

NE 1.13 Licenciamento de Minas e Usinas de Beneficiamento de Minérios de Urânio e/ou Tório NE

NN 1.14 Relatórios de Operação de Usinas Nucleoelétricas

NN 1.16 Garantia da Qualidade para a Segurança de Usinas Nucleoelétricas e Outras Instalações

NN 1.17 Qualificação de Pessoal e Certificação para Ensaios Não-destrutivos em Itens de Instalações Nucleares

NE 1.18 Conservação Preventiva em Usinas Nucleoelétricas

NE 1.19 Qualificação de Programas de Cálculo para Análise de Acidentes de Perda de Refrigerante em Reatores a Água Pressurizada

NE 1.20 Aceitação de Sistemas de Resfriamento de Emergência do Núcleo de Reatores a Água Leve

NE 1.21 Manutenção de Usinas Nucleoelétricas

NE 1.22 Programas de Meteorologia de Apoio de Usinas Nucleoelétricas

NE 1.24 Uso de Portos, Baías e Águas sob Jurisdição Nacional por Navios Nucleares.

NE 1.25 Inspeção em Serviço em Usinas Nucleoelétricas

NE 1.26 Segurança na Operação de Usinas Nucleoelétricas

Posições Regulatórias

1.26 / 001 - Gerenciamento de Rejeitos Radioativos em Usinas Nucleoelétricas

NE 1.27 Garantia da Qualidade na Aquisição, Projeto e Fabricação de Elementos Combustíveis.

NE 1.28 Qualificação e Atuação de Órgãos de Supervisão Técnica Independente em usinas Nucleoelétricas e Outras Instalações

Res 09/69 Normas para Escolha de Locais para Instalação de Reatores de Potência 
TABELA A.2 - Grupo 2 - Controle de Materiais Nucleares, Proteção Física e Proteção contra Incêndio

Grupo 2 - Controle de Materiais Nucleares, Proteção Física e Contra incêndio

NE 2.01 Proteção Física de Unidades Operacionais da Área Nuclear

NN 2.02 Controle de Materiais Nucleares

NN 2.03 Proteção contra Incêndio em Usinas Nucleoelétricas

NE 2.04 Proteção contra Incêndio em Instalações Nucleares do Ciclo do Combustível

Fonte: (CNEN - NORMAS, 2012)

TABELA A.3 - Grupo 3 - Proteção Radiológica

\section{Grupo 3 - Proteção Radiológica}

NN 3.01 Diretrizes Básicas de Proteção Radiológica

Posições Regulatórias

3.01 / 001:2011 - Critérios de exclusão, isenção e dispensa de requisitos de proteção radiológica

3.01 / 002:2011 - Fatores de ponderação para as grandezas de proteção radiológica

3.01 / 003:2011 - Coeficientes de dose para indivíduos ocupacionalmente expostos

3.01 / 004:2011 - Restrição de dose, níveis de referência ocupacionais e classificação de áreas

3.01 / 005:2011 - Critérios de cálculo de dose efetiva a partir da monitoração individual

3.01 / 006:2011 - Medidas de proteção e critérios de intervenção em situações de emergência

3.01 / 007:2005 - Níveis de intervenção e de ação para exposição crônica

3.01 / 008:2011 - Programa de monitoração radiológica ambiental

3.01 / 009:2011 - Modelo para elaboração de relatórios de programa de monitoração radiológica ambiental

3.01 / 010:2011 - Níveis de dose para notificação à CNEN

3.01 / 011:2011 - Coeficientes de dose para Exposição do Público

NE 3.02 Serviços de Radioproteção

Res 111/11 Certificação da Qualificação de Supervisores de Proteção Radiológica

NN 3.05 Requisitos de Radioproteção e Segurança para Serviços de Medicina Nuclear

Res 130/12 Requisitos de Segurança e Proteção Radiológica para Serviços de Radioterapia 
TABELA A.4 - Grupo 4 - Materiais, Minérios e Minerais Nucleares

\section{Grupo 4 - Materiais, Minérios e Minerais Nucleares}

NN 4.01 Requisitos de Segurança e Proteção Radiológica para Instalações MíneroIndustriais

Res 03/65 Fixa normas no que se referem aos minerais, minérios nucleares e de interesse para a energia nuclear

Res 04/69 Define regras para o exportador de minerais ou minérios que contenham elementos nucleares

Res 08/77 Esclarece a regra para o exportador (na Resolução 04/69), caso não seja possível a aquisição no mercado externo

Res 18/88 Estabelece critérios de dispensa de requisitos para exportadores

Port279/97 Define regras para a importação de produtos à base de lítio.

Res $113 / 11$ Nível de isenção para o uso do fosfogesso na agricultura ou na indústria cimenteira

Fonte: (CNEN - NORMAS, 2012)

TABELA A.5 - Grupo 5 - Transporte de Materiais Radioativos

\section{Grupo 5 - Transporte de Materiais Radioativos}

NE 5.01 Transporte de Materiais Radioativos

Posições Regulatórias

5.01 / 001 - Transporte de material radioativo por motocicletas

NE 5.02 Transporte, Recebimento, Armazenagem e Manuseio de Elementos Combustíveis de Usinas Nucleoelétricas

NE 5.03 Transporte, Recebimento, Armazenagem e Manuseio de Itens de Usinas Nucleoelétricas

Fonte: (CNEN - NORMAS, 2012)

TABELA A.6 - Grupo 6 - Instalações Radiativas

\section{Grupo 6 - Instalações Radiativas}

NN 6.01 Requisitos para o Registro de Pessoas Físicas para o Preparo, Uso e Manuseio Fontes Radioativas.

Res 112/11 Licenciamento de Instalações Radiativas

NN 6.04 Funcionamento de Serviços de Radiografia Industrial

NE 6.05 Gerência de Rejeitos Radioativos em Instalações Radiativas

NE 6.06 Seleção e Escolha de Locais para Depósitos de Rejeitos Radioativos

NN 6.09 Critérios de Aceitação para Deposição de Rejeitos Radioativos de Baixos e Médios Níveis de Radiação 
TABELA A.7 - Grupo 7 - Certificação e Registro de Pessoas

\section{Grupo 7 - Certificação e Registro de Pessoas}

Res 109/11 Licenciamento de Operadores de Reatores Nucleares

NN 1.17 Qualificação de Pessoal e Certificação para Ensaios Não-destrutivos em Itens de Instalações Nucleares

Res 111/11 Certificação da Qualificação de Supervisores de Proteção Radiológica

NN 6.01 Requisitos para o Registro de Pessoas Físicas para o Preparo, Uso e Manuseio Fontes Radioativas

NN 6.04 Funcionamento de Serviços de Radiografia Industrial

Fonte: (CNEN - NORMAS, 2012)

TABELA A.8 - Grupo 8 - Rejeitos Radioativos

\section{Grupo 8 - Rejeitos Radioativos}

NE 6.05 Gerência de Rejeitos Radioativos em Instalações Radiativas

NE 6.06 Seleção e Escolha de Locais para Depósitos de Rejeitos Radioativos

NN 6.09 Critérios de Aceitação para Deposição de Rejeitos Radioativos de Baixos e Médios Níveis de Radiação

Res 04/89 Para-raios com material radioativo

Posições Regulatórias

1.26 / 001 - Gerenciamento de Rejeitos Radioativos em Usinas Nucleoelétricas

Fonte: (CNEN - NORMAS, 2012) 
ANEXO B - Grupos de trabalho do IPEN

TABELA B.1 - Grupo de Trabalho para Atividades de Licenciamento do IPEN

\begin{tabular}{|c|c|}
\hline Grupo & Nome \\
\hline 1 & Reator IEA-R1 \\
\hline 2 & Reator IPEN-MB-01 \\
\hline 3 & Centro do Combustível Nuclear \\
\hline 4 & Cíclotrons \\
\hline 5 & Radiofarmácia \\
\hline 6 & Laboratório de Metrologia Nuclear \\
\hline 7 & Laboratórios do Centro de Reator de pesquisa \\
\hline 8 & $\begin{array}{l}\text { Laboratório de Produção de Fontes Radioativas } \\
\text { para Fins de Braquiterapia }\end{array}$ \\
\hline 9 & $\begin{array}{l}\text { Laboratório de Produção de Fontes Seladas para } \\
\text { Fins Industriais }\end{array}$ \\
\hline 10 & Laboratório de Fontes Intensas \\
\hline 11 & Irradiador Multipropósito \\
\hline 12 & $\begin{array}{l}\text { Laboratório de Manipulação de traçadores } \\
\text { radioativos }\end{array}$ \\
\hline 13 & $\begin{array}{l}\text { Laboratório de Produção de Fontes de Referência } \\
\text { para o Controle de Qualidade de Curiômetros }\end{array}$ \\
\hline 14 & $\begin{array}{l}\text { Laboratório de Tomografia Computadorizada } \\
\text { Industrial }\end{array}$ \\
\hline 15 & Divisão de Calibração e Dosimetria \\
\hline 16 & Divisão de Radiometria Ambiental \\
\hline 17 & Laboratórios do Centro de Laser e Aplicações \\
\hline 18 & Laboratórios do Centro de Biologia Molecular \\
\hline 19 & $\begin{array}{l}\text { Laboratórios de Centro de Química e Meio } \\
\text { Ambiente }\end{array}$ \\
\hline 20 & $\begin{array}{l}\text { Laboratórios do Centro de Ciência e Tecnologia } \\
\text { dos materiais }\end{array}$ \\
\hline 21 & Galpão de Rejeitos \\
\hline 22 & Unidade de Tratamento de para-raios radioativos \\
\hline 23 & Unidade de Compactação de Rejeitos \\
\hline
\end{tabular}




\section{REFERÊNCIAS BIBLIOGRÁFICAS}

A Eletrobras Eletronuclear. Eletrobras Eletronuclear, 2013. Disponível em: <http://www.eletronuclear.gov.br/AEmpresa.aspx>. Acesso em: 20 mar. 2014.

AAKER, D. A.; KUMAR, V.; DAY, G. S. Pesquisa de Marketing. 2. ed. São Paulo: Atlas, 2004.

AKINS, R. N. In AERA Division D: Measuremente and Research Methodology Forum [online], NJ Dept. of education, 19 nov. 2002.

ALVES, J. A. L. A Cúpula Mundial sobre o Desenvolvimento Social e os paradoxos de Copenhague. Revista Brasileira de Política Internacional, Brasilia, v. 40, n. 1, Janeiro Junho 1997. Disponível em: 〈http://dx.doi.org/10.1590/S0034-73291997000100006 > . Acesso em: 2012 set. 14.

ASENDORPF, J. B. Psychologie der Personlichkeit. Berlin: Springer, 2004.

ASHLEY, P. A. Ética e Responsabilidade Social nos Negócios. São Paulo: Saraiva, 2005.

AZAPAGIC, A. Developing a framework for sustainable development indicators for and minerals industry. Journal of Cleaner Production, 12 (6), 2004. 639-662.

BARBIERI, J. C.; CAJAZEIRA, J. E. R. Responsabilidade e Sensibilidade Social. Scribd, 2009. Disponível em: <http://pt.scribd.com/doc/49166336/Barbieri-Cajazeira-2009>. Acesso em: 16 ago. 2012.

BARBIERI, J. C.; CAJAZEIRA, J. E. R. Responsabilidade Social Empresarial e Empresa Sustentável. São Paulo: Saraiva, 2010.

BARBIERI, J. C.; CAJAZEIRA, J. E. R. Responsabilidade Social Empresarial e Empresa Sustentável. 2. ed. São Paulo: Saraiva, 2012.

BELLEN, H. V. Indicadores de sustentabilidade: uma análise comparativa. Rio de Janeiro: FGV Editora, 2005.

BHASIN,B. The Global Compact. Global Bhasin, 16 jul. 2012. Disponível em: <http://globalbhasin.blogspot.com.br/2012/07/global-compact.html>. Acesso em: 29 jun. 2014.

BOX,J.F,,Guiness, Gosset, Fisher and Small Samples: Statistical Science, 1987.

BSD CONSULTING. business. sustainability.development. BSD Consulting, 1998. Disponível em: <http://www.bsdconsulting.com/ptpt/about>. Acesso em: 24 setembro 2012. 
BSD CONSULTING. Nova Arquitetura para Indicadores Ethos. BSD Consulting, 2012. Disponível em: <http://www.bsdconsulting.com/ptpt/insights/article/new-architecture-forethos-indicators>. Acesso em: 25 setembro 2012.

CAMPOS, J. G. F. Agenda 21: da Rio 92 ao local de trabalho. São Paulo: Iglu, 1995.

CARROLL, A. B. A Three-dimentional conceptual model of corporate performance. Academy of management Review, v. 4, n. 4, 1979.

CARROLL, A. B. The Pyramid of Corporate Social Responsibility: Toward The Moral Management of Organizational Stakeholders. Business Horizons, julho-agosto 1991.

CARROLL, A. B. Corporate Social Responsibility: Evolution of a Definitional Construct. Business and Society, v.38, n. 3, set. 1999. p.268-295.

CARROLL, A. B.; SCHWARTZ, M. Corporate social responsibility: a three-domain approach. Business Ethics Quarterly, Chicago, Vol.13, 2003. 503-530.

CHAVES, D. Índice Dow Jones de Sustentabilidade mantém sete companhias brasileiras. Economia \& Negócios - O Estado de São Paulo, 2010. Disponível em: $<$ http://economia.estadao.com.br/noticias/economia,indice-dow-jones-de-sustentabilidademantem-sete-companhias-brasileiras,34704,0.htm>. Acesso em: 14 setembro 2012.

CHIN, W. W. Issues and opinion on strutural equation modeling. MIS Quarterly, 22, n. 1, March 1998. VII-XVI.

CHIN, W. W.; MARCOLIN, B. L.; NEWSTED, P. R. A Partial Least Squares Latent Variable Modeling Approach for Measuring Interaction Effects: Results from a Monte Carlo Simulation Study and Eletronic-Mail Emotion/Adoption Study. Information Systems Research, Vol. 14, n. 2, June 2003. 189-217.

CHURCHILL, G. A. A Paradigm for Developing Better Measures of Marketing Constructs. Journal of Marketing Research, XVI, February 1979. 64-73.

CHURCHILL, G. A. Marketing Research: Methodological Foundations. 3. ed. Chicago: Dryden, 1983.

CLARKSON, M. B. E. A stakeholder framework for analyzing and evaluating corporate social performance. Academy of Management, janeiro 1995. Disponível em: <http://www.jstor.org/pss/258888>. Acesso em: 04 dezembro 2011.

CMMAD - COMISSÃO MUNDIAL SOBRE MEIO AMBIENTE E DESENVOLVIMENTO. Report of the World Comission on Environment and Development: Our Common Future. Noruega: [s.n.]. 1987.

CNEN - ATIVIDADES. Atividades. Comissão Nacional de Energia Nuclear, 2006. Disponível em: <http://www.cnen.gov.br/acnen/atividades.asp>. Acesso em: 19 outubro 2012. 
CNEN - ATIVIDADES. CNEN - Atividades. Comissão Nacional de Energia Nuclear, 2012. Disponível em: <http://www.cnen.gov.br/acnen/atividades.asp>. Acesso em: 08 outubro 2012.

CNEN - LICENCIAMENTO. Licenciamento, Fiscalização e Controle. Comissão Nacional de Energia Nuclear, 2013. Disponível em:

<http://www.cnen.gov.br/seguranca/lfc/lic-fis-cont.asp\#>. Acesso em: 18 outubro 2012.

CNEN - NORMAS. Normas em Vigor. Comissão Nacional de Energia Nuclear, 2012. Disponível em: <http://www.cnen.gov.br/seguranca/normas/normas.asp>. Acesso em: 18 outubro 2012.

CNEN - PROTEÇÃO RADIOLÓGICA. Proteção Radiológica. Comissão Nacional de Energia Nuclear, 2012. Disponível em:

<http://www.cnen.gov.br/seguranca/radioprotecao.asp>. Acesso em: 18 outubro 2012.

CNEN. Segurança de Sistemas de Barragem de Rejeitos Contendo Radionuclídeos. CNEN - Comissão Nacional de Energia Nuclear, 1980. Disponível em:

<http://www.cnen.gov.br/seguranca/normas/mostra-resumo.asp?op=110>. Acesso em: 11 outubro 2012.

CNEN. CNEN - Atividades. CNEN - Comissão Nacional de Energia Nuclear, 2012. Disponível em: <http://www.cnen.gov.br/acnen/atividades.asp>. Acesso em: 08 outubro 2012.

CNUMAD. Agenda 21 - Conferência das Nações Unidas sobre o Meio Ambiente e Desenvolvimento. Brasília: Bibliotéca Digital da Câmara dos Deputados. 1995.

COMISSION ON SUSTAINABLE DEVELOPMENT. Indicators of sustainable development: guidelines and methodologies, 2007. Disponível em: <http://www.un.org/esa/sustdev/natlinfo/indicators/guidelines.pdf >. Acesso em: 14 out. 2013.

COMITÊ DE SUSTENTABILIDADE EMPRESARIAL. Relatório de Sustentabilidade Socioambiental 2012. Eletrobras Eletronuclear. Rio de Janeiro. 2013. http://www.eletronuclear.gov.br/LinkClick.aspx?fileticket=TRgh3BIgd0A\%3d\&tabid=289

CONFERÊNCIA Internacional sobre Responsabilidade Social das Empresas. Compete Programa Operacional Factores de Competitividade, 2010. Disponivel em: $<$ http://www.pofc.qren.pt/media/noticias/entity/conferencia-internacional-sobreresponsabilidade-social-das-empresas?fromlist=1>. Acesso em: 16 jun. 2014.

CONVENÇÃO de Viena e Protocolo de Montreal. Ministério do Meio Ambiente, 2012. Disponível em: <http://www.mma.gov.br/clima/protecao-da-camada-deozonio/convencao-de-viena-e-protocolo-de-montreal>. Acesso em: 14 set. 2012. 
CONVENÇÃO QUADRO DAS NAÇÕES UNIDAS SOBRE MUDANÇA DO CLIMA.

Protocolo de Kyoto. Kyoto: Ministério da Ciência e Tecnologia com apoio do Ministério das Relações Exteriores da república Federativa do Brasil. 1998.

COOPER, D. R.; SCHINDLER, P. G. S. Métodos de Pesquisa em Administração. 7. ed. Porto Alegre: Bookman, 2003.

CORPORATE Social Responsibility Focus of Brazil Conference. IIP Digital - U.S. Departmtent of State, 2006. Disponivel em:

<http://iipdigital.usembassy.gov/st/english/article/2006/12/200612131746081xeneerg0.512 199.html\#ixzz34uuVJ3x2>. Acesso em: 16 jun. 2014.

CORPORATE Sustainability Assessment. Dow Jones Sustainability Indices, 2013. Disponível em: <http://www.sustainability-indices.com/sustainabilityassessment/corporate-sustainability-assessment.jsp>. Acesso em: 29 jun. 2014.

CRONBACH, L. J. My current thougts on coeficient alpha and sucessors procedures. Educational and Psychologycal Measurement, v. 64, n. 3, p. 391-418, 2004.

CUNHA,L.M.A. Modelos Rasch e Escalas de Likert e Thurstone na Medição da Atitude. Lisboa. 2007. Dissertação (Mestrado) - Universidade de Lisboa.

CÚPULA MUNDIAL SOBRE DESENVOLVIMENTO SUSTENTÁVEL. Declaração de Joanesburgo sobre Desenvolvimento Sustentável. Joanesburgo: [s.n.]. 2002.

CUSTODIO, A. L. D. M.; MOYA, R. Indicadores Ethos de Responsabilidade Social Empresarial. São Paulo: Instituto Ethos, 2007.

CUSTODIO, A. L. M.; MOYA, R. Indicadores Ethos de Responsabilidade Social Empresarial. São Paulo: Institito Ethos, 2007.

DECLARAÇÃO da Conferência das Nações Unidas Sobre o Meio Ambiente Humano. Estocolmo: [s.n.]. 1972.

DELAI, I.; TAKAHASHI, S. Uma Proposta de Modelo de Referência para Mensuração da Sustentabilidade Corporativa. RGSA - Revista de Gestão Social e Ambiental, v. 2, n. 1, p. 19-40, janeiro - abril 2008.

DELAI, I.; TAKAHASHI, S. Uma proposta de modelo de referência para mensuração da sustentabilidade corporativa. Revista de Gestão Social e Ambiental, V.2, n. 1, Jan-Abr 2008. 19-40.

DIAMANTOPOULOS, A.; SIGUAW, J. A. Formative versus Reflexive Indicators in Organizational Measure Development: A Comparasion and Empirical Illustration. British Journal of management, 17, n. 4, December 2006. 263-282.

DONALDSON, T.; PRESTON, L. E. The stakeholder theory of the corporation: concepts, evidence and implications. Academy of management, janeiro 1995. Disponível em: <http://www.jstor.org/pss/258887>. Acesso em: 04 dezembro 2011. 
DOW JONES INDEXES. Dow Jones sustainability world indexes guide v.12.2, 2013. Disponível em: <http://www.sustainability-indices.com/images/djsi-worldguidebook_tcm1071-337244.pdf>. Acesso em: 16 out. 2013.

DRUCKER, P. F. Converting Social Problems into Business Opportunities: The New Meaning of Corporate Social Responsibility. California Management Review, 26, n. 2, 1984. 53-63.

DUARTE, G.; DIAS, J. M. Responsabilidade social: a empresa hoje. Rio de Janeiro: Livros Técnicos e Científicos, 1986.

EDWARDS, J. R.; BAGOZZI, R. P. On the nature and direction of relationships between constructs and measures. Psychological Methods, Vol 5(2), June 2000. 155-174.

EISENHARDT, K. M. Building Theories from Case Study Research. Academy of Marketing, Vol. 14, n. 4, 1989.

EMBRAPA - MEIO AMBIENTE. ISO, Inmetro, ABNT e normalização, 2001. Disponível em: <http://www.cnpma.embrapa.br/projetos/prod_int/normalizacao.html>. Acesso em: 28 setembro 2012.

ESTADO. Manual para Elaboração, Administração e Avaliação de Projetos Socioambientais. São Paulo: SMA / CPLEA, 2005. 32 p.

ETHOS. Indicadores Ethos para negócios responsáveis e sustentáveis, 2013. Disponível em: <http://www3.ethos.org.br/wp-content/uploads/2013/09/Desenvolvimento-dos-novosIndicadores-Ethos1.pdf $>$. Acesso em: 16 out. 2013.

FALCONER, A. P.; VILELA, R. Recursos privados para fins públicos: as grantmakers brasileiras. São Paulo: Petrópolis, 2001.

FARIAS FILHO, J. R. Sumário da Ação estratégica de Negócios. Rio de Janeiro: Eduff, 2000. $14 \mathrm{p}$.

FERNANDES, R. C. Privado porém público: o Terceiro Setor na América Latina. Rio de Janeiro: Relume-Dumará, 1994.

FISHER, R. M. O Desafio da Colaboração: Práticas de Responsabilidade Social entre Empresas do terceiro Setor. São Paulo: Gente, 2002.

FORNELL, C.; BOOKSTEIN, F. L. Two Structural Equation Models: LISREL and PLS Applied to Consumer Exit - Voice Theory. Journal of Marketing Research, Vol. 19, n. 4, November 1982. 440-452. Special Issue on Causal Modeling.

FREEMAN, R. E. Strategec management: a stakeholder approach. Massachusetts: Pitman, 1984.

FREITAS, A. L. P.; RODRIGUES, S. G. A avaliação da confiabilidade de questionários: uma análise utilizando o coeficiente Alfa de Cronbach. XII SIMPEP, Bauru/SP/Brasil, Novembro 2005. 
FRIEDMAN, M. The Social Responsibility of Business is to Increase Its Profits. The New York Times, 13 set. 1970.

FROES, C.; MELLO NETO, F. P. Responsabilidade Social \& CidadaniaEmpresarial: A Administração do Terceiro Setor. Rio de Janeiro: Qualitymark, 1999.

GALHANONE, R. F. Valor Percebido Pelo Consumidor de Produtos de Luxo: Proposição de Um Modelo Teórico, 2013. Tese (Doutorado) - Universidade de São Paulo, São Paulo.

GALLOPÍN, G. Indicators and their use: information for decision-making. In: MOLDAN, B.; BILHARZ, S. Sustainability indicartors: report of the project on indicators of sustainable development. Chicester: Wiley, 1997.

GARVER, M.; MENTZER, J. T. Logistics research methods: Employng structural equation modeling to test for construct validity. Journal of Business Logistics, v. 20, n. 1, p. 33-57, 1999.

GEFEN, D.; RIGDON, E. E.; STRAUB, D. An Update and Extension to SEM Guidelines for Administrative and Social Science Research. MIS Quarterly, Vol.35, n. 2, June 2011. iii-xiv.

GEFEN, D.; STRAUB, D. A Practical Guide to Factorial Validity Using PLS - GRAPH: Tutorial and Annotated Example. Communications of the Association for Information Systems, Vol. 16, 2005. 91-109.

GERENCIAMENTO da Qualidade em Projetos. Scribd, 2008. Disponível em: <http://pt.scribd.com/doc/37039279/GerenciamentoQualidade>. Acesso em: 23 outubro 2012 .

GESTÃO \& RH. IDHO e Cidadania Corporativa. Gestão \& RH, 2012. Disponível em: <http://www.gestaoerh.com.br/site/noticias/?id=82>. Acesso em: 08 outubro 2012.

GHIGliOne, R.; MATALON, B. O Inquérito - Teoria e Prática. Celta: [s.n.], 1992. 55$57 \mathrm{p}$.

GIFE. Guia GIFE sobre Investimento Social Privado - Como Iniciar um Programa de Ação Social na sua Empresa. São Paulo: GIFE, 2002.

GIL, A. C. Métodos e Técnicas de Pesquisa Social. São Paulo: Atlas, 1999.

GLOBAL Compact. Instituto Ethos - Empresas e Responsabilidade Social, 2003. Disponível em:

<http://www.ethos.org.br/DesktopDefault.aspx?TabID=3368\&Alias=ethos\&Lang=ptBR>. Acesso em: 14 setembro 2012.

GLOBAL REPORTING INITIATIVE. Sustainability reporting guidelines, 2013. Disponível em: <https://www.globalreporting.org>. Acesso em: 15 out. 2013. 
GRAJEW, O. O que é responsabilidade Social? Instituto Ethos de responsabilidade Social, novembro 1999. Disponível em: <http://www.ethos.org.br>. Acesso em: 26 agosto 2012.

GRAJEW, O. Pessoa física em paz com a jurídica. Valor Econômico, 01 junho 2000. B-2.

GREENING, D. W.; TURBAN, D. B. Corporate Social Performance as a competitivity advantage in attract a quality workforce. Business \& Society, setembro 2011. Disponível em: <http://bas.sageup.com/content/39/3/254/short>. Acesso em: 04 dezembro 2011.

GUEDES, R. C. Responsabilidade Social e Cidadania Empresarial: conceitos estratégicos para as empresas frente à globalização. [S.1.]. 2000. Dissertação (Mestrado) - Pontíficia Universidade Católica de São Paulo, São Paulo.

HAIR, J. F. et al. Multivariate Data Analysis. 6. ed. Upper Saddle River: Prentice Hall, 2006.

HAIR, J. F. et al. Multivariate Data Analysis: A Global Perspective. 7. ed. [S.1.]: Pearson Education, 2009.

HAIR, J. F. et al. An assesment of use of partial least squares structural equation modeling in marketing research. Journal of the Academy of Marketing Science, v. 40, n. 3, p. 414433, may 2012.

HAIR, J. F.; RINGLE, C. M.; SARSTEDT, M. PLS-SEM: Indeed a Silver Bullet, v. 19, n. 2, p. 139-151, Spring 2011.

HARDI, P.; ZDAN, T. J. The Dashboard of sustainability. Winnipeg: IISD. HART,S.L.; MILSTEIN,M. (2004). Criando valor sustentável. RAE Executivo, 3(2), 2000. 65-79.

HAYES, B. E. Medindo a satisfação do cliente. Rio de Janeiro: Qualitymark, 1995. 228 p.

HENSELER, J.; RINGLE, C. M.; SINKOVICS, R. R. Use of Partial Least Squares Path Modeling in International marketing. Advances in International Marketing, v. 20, p. 277-319, 2009.

HOGAN, D. J.; VIEIRA, P. F. Dilemas Socioambientais e Desenvolvimento Sustentável. São Paulo: UNICAMP, 1995.

HUBBARD, R.; LINDSAY, R. M. Why P values are not as useful measure of evidence in statistical significance testing. Theory Psychol, n. 18, 2008. 69-88.

HULLAND, J. Use of partial least squares (PLS) in strategic management research: A review of four recent studies. Strategic Management Journal, Vol. 20, n. 2, February 1999. 195-204.

INSTITUTION OF CHEMICAL ENGINEERS. The sustainability metrics, 2002.

Disponível em:

<http://www.icheme.org/communities/subject_groups/sustainability/resources/ /media/Do 
cuments/Subject\%20Groups/Sustainability/Newsletters/Sustainability\%20Metrics.ashx>. Acesso em: 15 out. 2013.

INSTITUTO ETHOS. Como esta a gestão da responsabilidade social na sua empresa? Indicadores Ethos de responsabilidade Social Empresarial, 2011. Disponível em: $<$ http://www.ethos.org.br/docs/conceitos_praticas/indicadores/default.asp >. Acesso em: 25 setembro 2012.

INSTITUTO ETHOS. Sobre o Instituto. Instituto Ethos, 2013. Disponível em: <http://www3.ethos.org.br/conteudo/sobre-o-instituto/missao/\#.Un-IPjFTvIU>. Acesso em: 10 novembro 2013.

IPCC - Painel Intergovernamental sobre Mudança do Clima. Mudanças Climáticas, 2002. Disponível em: <http://www.mudancasclimaticas.andi.org.br/content/ipcc-painelintergovernamental-sobre-mudanca-do-clima-intergovernmental-panel-climate-change>. Acesso em: 2012 set. 14.

IPEN - AÇÕES DE CIDADANIA. IPEN - Ações de Cidadania. Instituto de Pesquisas Energéticas e Nucleares, 2011. Disponível em: <https://www.ipen.br/sitio/?idm=157>. Acesso em: 08 outubro 2012.

IPEN - INTRODUÇÃO AO CEN. IPEN - Introdução ao CEN, São , 2012. Disponível em: <https://www.ipen.br/sitio/index.php?idm=20>. Acesso em: 16 jul. 2013.

IPEN - MEIO AMBIENTE. Meio Ambiente. IPEN - Instituto de Pesquisas Energéticas e Nucleares, 2009. Disponível em: 〈https://www.ipen.br/sitio/index.php?idc=6581 > . Acesso em: 11 outubro 2012.

IPEN - MISSÃO. O IPEN - Missão. Instituto de Pesquisas Energéticas e Nucleares, 2011. Disponível em: <https://www.ipen.br/sitio/?idm=2>. Acesso em: 05 outubro 2012.

IPEN - QUEM SOMOS. O IPEN - Quem somos. Instituto de Pesquisas Energéticas e Nucleares, 2011. Disponível em: <https://www.ipen.br/sitio/?idm=3>. Acesso em: 21 setembro 2012.

IPEN / CNEN. Plano Diretor 2011 - 2020, São Paulo, 24 out. 2011. Disponível em: <http://www.ipen.br/conteudo/upload/201111101234070.PLANO\%20DIRETOR_20112020_rev_1.pdf>. Acesso em: 20 dez. 2013.

IPEN/CNEN. Relatório de Gestão 2012. Ministério da Ciência, Tecnologia e Inovação; Comissão Nacional de Energia Nuclear; Instituto de Pesquisas Energéticas e Nucleares. São Paulo. 2013.

JARVIS, C. B.; MACKENZIE, S. B.; PODSAKOFF, P. M. A Critical review of Construct Indicators and Measurement Model Misspecification in marketing and Consumer Research. Journal of Consumer Research, 30, September 2003. 199-218.

JOHNSON, B. In AERA Division D: Measurement and Research Methodology Forum [online], Southalabama, 19 nov. 2002. 
KANITZ, S. O que é o Terceiro Setor? Filantropia.org ajudando quem quer ajudar, 2012. Disponível em: <http://www.filantropia.org/OqueeTerceiroSetor.htm>. Acesso em: 2012 setembro 21.

KRAJNC, D.; GLAVIC, P. Indicators of sustainable development. Clean Technology Environment Policy, n. 5, 2003. 279-288.

KRAJNC, D.; GLAVIC, P. A model for integrated asnt of sustainable development. Resources, Conservation \& Recycling, 43(2), 2005.

LABUSCHAGNE, C.; BRENT, C. A.; ERCK, R. P. G. V. Assessing the sustainability performance of industries. Journal of Cleaner Production, 13(4), 2005. 373-385.

LAURENTI, R. Objetivos do desenvolvimento do milênio. Revista da Associação Médica Brasileira, São Paulo, v. 51, Jan/Feb 2005. ISSN ISSN 0104-4230.

LIMA, C. Clube de Roma debate futuro do planeta há 4 décadas. PUC - Rio Digital, 2012. Disponível em: <http://puc-riodigital.com.pucrio.br/cgi/cgilua.exe/sys/start.htm?sid=148\&infoid=12080>. Acesso em: 13 set. 2012.

MAIGNAN, I.; FERRELL, O. C.; HULT, G. T. M. Corporate Citizenship: Cultural Antecedents and Business Benefits. Journal of Academy of marketing Science, outubro 2006. Disponível em: <http://1a0,sage4*,c600c6ntent027/04/455.short>. Acesso em: 04 dezembro 2011.

MALHOTRA, N. K. Marketing Research: An applied orientation. 5. ed. Upper Saddle River: Pearson Prentice Hall, 2006.

MARCONI, M. A.; LAKATOS, E. M. Fundamentos de Metodologia Científica. 5. ed. São Paulo: Atlas, 2003.

MARÔCO, J. Análise de Equações Estruturais: Fundamentos teóricos, software e aplicações. Pêro Pinheiro: Report Number, 2010.

MCCOLL, S.; STANKEY, G. Indicators of sustainability: Challenges and opportunities at the interface of science and policy. Environmental Management, 33, 2004. 295-305.

MELO NETO, F. P. M.; FROES, C. Responsabilidade Social \& Cidadania

Empresarial. Rio de Janeiro: Editora Eletrônica Equipe Qualitymark, 2001.

MELO NETO, F. P.; FROES, C. Gestão da responsabilidade Social Corporativa: o caso brasileiro. Rio de Janeiro: Qualitymark, 2001.

MELO NETO, F. P.; FROES, C. Gestão da responsabilidade Social Corporativa: o caso brasileiro. Rio de Janeiro: Qualitymark, 2004.

MENDES, A.; SILVA, F. Capital Humano: essencial para o desenvolvimento sustentável. Revista Espaço Acadêmico, n. 93, fevereiro 2009. Disponível em: <http://www.espacoacademico.com.br/093/93amsf.htm>. Acesso em: 04 outubro 2012. 
MENDONÇA, R. R. S. D. Responsabilidade social das empresas: a contribuição das universidades. São Paulo: Peirópolis: Instituto Ethos, v. II, 2003. 205-231 p.

MEXICO City to Host Conference on Corporate Social Responsibility. IIP Digital - U.S. Department of State, 2004. Disponivel em:

<http://iipdigital.usembassy.gov/st/english/article/2004/08/20040826125844aeneerg0.2016 87.html\#axzz34uDEB9Qf>. Acesso em: 16 jun. 2014.

MILLER, D. C. Handbook of Research Design \& Social Measurement. 5. ed. Thousand Oaks: Sage, 1991.

MITCHELL, R. K.; AGEL, B. R.; WOOD, D. J. Toward a theory of stakeholder identification and salience: defining the principle of who and what really counts. Academy of Management, outubro 1997. Disponível em: <http://www.jstor.org./pss/259247>.

Acesso em: 04 dezembro 2011.

MOLDAN, B.; BILHARZ, S. Introduction. In: MOLDAN, B.; BILHARZ, S.

Sustainability indicators: report of the project in indicators of sustainable development.

Chichester: Wiley, 1997.

MUELLER, C. C. Avaliação de duas correntes da economia ambiental: a escola neoclássica e a economia da sobrevivência. Revista de Economia Política, v.18, n. 2 (70), abril-junho 1998.

NASA divulga descoberta de buraco na camada de ozônio no Ártico. Zero Hora, 10 outubro 2011. Disponível em:

<http://zerohora.clicrbs.com.br/rs/geral/noticia/2011/10/nasa-divulga-descoberta-deburaco-na-camada-de-ozonio-no-artico-3511862.html>. Acesso em: 17 setembro 2012.

O primeiro choque do petróleo. Folha On Line, 2000. Disponível em:

<http://www1.folha.uol.com.br/folha/dinheiro/petroleo_choque1.shtml>. Acesso em: 14 setembro 2012.

ONWUEGBUZIE, A. J.; LEECH, N. L. On Becoming a Pragmatic Researcher: The Importance of Combining Quantitative and Qualitative Research Methodologies.

International Journal of Social Research Methodology, Vol. 8, n. 5, 2005. 375-387.

ORGANIZAÇÕES Não Governamentais. Instituto Mundial para as Relações

Internacionais, 2011. Disponível em: <http://www.irwi.org.br/ongsinternacionais.htm>. Acesso em: 14 setembro 2012.

PAGANO,M., GAUVREAU,K., Princípios da Bioestatística, São Paulo: Thomson Pioneira, 2004.

PETER, J. P. Reliability: A Review of Psychometric Basics and Recent Marketing Practicies. Journal of Marketing Research, Vol. 16, n. 1, February 1979. 6-17.

POPPER, K. R. A lógica da pesquisa científica. 12. ed. São Paulo: Cultrix, 2006. 
PORTARIA CNEN/IPEN N.96. Portaria CNEN/IPEN N.96, de 26 de abril de 2012. Rio de Janeiro: CNEN. 2012.

PRESTCOTT-ALLEN, R. Barometer of sustainability. In: MOLDAN, B.; BILHARZ, S. Sustainability indicators: report of the project on indicators of sustainable development. Chicester: Wiley, 1997.

PROGRAMA Tear - Tecendo Redes Sustentáveis. Instituto Ethos - Empresas e responsabilidade Social, 2007. Disponível em:

<http://www.ethos.org.br/DesktopDefault.aspx?TabID=4213\&Alias=ethos\&Lang=ptBR>. Acesso em: 24 setembro 2012.

PUSCHEL, J.; MAZZON, J. A.; HERNANDEZ , J. M. C. Mobile banking: proposition of an integrated adoption intention framework. International Journal of Bank Marketing, Vol. 28, Iss: 5, 2010. 389-409.

REIS, C. N. A responsabilidade social das empresas: o contexto brasileiro em face da ação consciente ou do modernismo do mercado? Revista de Economia Contemporânea, Rio de Janeiro, v. 11, n. 2, maio-agosto 2007.

REUTERS, D. Buraco da camada de ozônio está menor que no ano passado, diz ONU. G1-Natureza, 14 set. 2012. Disponível em:

<http://g1.globo.com/natureza/noticia/2012/09/buraco-da-camada-de-ozonio-esta-menorque-no-ano-passado-diz-onu.html>. Acesso em: 17 set. 2012.

RINGLE, C. M.; SARSTEDT, M.; STRAUB, D. W. Editor's comments: a critical look at the use of PLS-SEM. MIS Quarterly, Vol. 36, n. 1, March 2012. iii-xiv.

RIO + 20. Rio + 20 Conferência das Nações Unidas para o Desenvolvimento

Sustentável, 2012. Disponível em: <http://www.rio20.gov.br/sobre_a_rio_mais_20>. Acesso em: 14 setembro 2012.

ROIG, J. C. F. et al. Customer perceived value in banking services. International Journal of Bank marketing, 24, n. 5, 2006. 266-283.

ROY, S. Measuring Formative Constructs in Management Research: Definitions Distinctions and Measurement. The Icfaian Journal of Management Research, Vol. VII, n. $10,2008.18-34$.

S\&P DOW JONES INDEXES. S\&P Dow Jones Indexes. Dow Jones Sustainability Indexes - in collaboration whith SAM, 2012. Disponível em: <http://www.sustainabilityindex.com/images/120913-djsi-review-2012-e-vdef_tcm1071-343064.pdf>. Acesso em: 08 outubro 2012.

SAAD,M.I. ETHOS Discursivo e Pilares. Note e Anote, 2012. Disponível em: <http://noteadote.blogspot.com.br/2012_10_01_archive.html> . Acesso em: 29 jun.2014.

SACHS, I. Caminhos para o desenvolvimento sustentável. [S.1.]: Garamond, 2002. 
SANTIAGO, R. D.; GOMES, E. R. Estratégias de responsabilidade socioambiental: análise comparativa dos conteúdos dos Websites de entidades fechadas de Previdência complementar. Revista Eletrônica Sistemas \& Gestão, Rio de Janeiro, v. 4, n. 1, p. 1635, janeiro - abril 2009.

SARSTEDT, M.; RINGLE, C. M. Treating unobserved heterogeneity in PLS path modeling: a comparison of FIMIX-PLS with different data analysis strategies. Journal of Applied Statistics, Vol. 37, n. 8, August 2010. 1299-1318.

SCHARADER, A. Introdução à Pesquisa Social Empírica. 2. ed. Porto Alegre: Globo, 1978.

SCHRADER, A. Introdução à Pesquisa Social Empírica. 2. ed. Porto Alegre: Globo, 1978.

SEARCY, C.; KARAPETROVIC, S.; MCCARTNEY, D. Designing sustainable development indicators: analysis for a case study. Measuring Business Excellence, 9(2), 2005. 33-41.

SELLTIZ, C. et al. Research Methods in Social Relations, Holt, Rinehart and Winston, Inc, 1959.

SIKDAR, S. K. Sustainable development and sustainability metrics. American Institute of Chemical Engineers Journal, 49(8), 2003. 1928-1932.

SMARTPLS Community. SmartPLS, 2005. Disponível em:

<http://www.smartpls.de/forum/>. Acesso em: 26 Fevereiro 2014.

SMARTPLS Community. SmartPLS, 2005. Disponível em:

<http://www.smartpls.de/forum/>. Acesso em: 26 fevereiro 2014.

STOICOV, C.; VÁRIOS COLABORADORES. Metodologia Tear de Trabalho em

Cadeia de Valor. São Paulo: Instituto Ethos, 2007.

STREINER, D. L.; NORMAN, G. R. Health measurement scales: a practical guide to their development and use. 2. ed. New York: Oxford University Press, 1995.

TABACHNICK, B. G.; FIDELL, S. Experimental Designs Using ANOVA. [S.1.]: Thomson/Brooks/Cole, 2007.

TORRES, C.; MANSUR, C. Balanço social, dez anos: o desafio da transparência. Rio de Janeiro: IBASE - Instituto Brasileiro de Análises Sociais e Econômicas, 2008.

TROCHIM, W. M. The Research Methods Knowledge Base, 20 outubro 2006. Disponível em: <http://www.socialresearchmethods.net/kb/>. Acesso em: 13 janeiro 2014.

TUCKMAN, B. W. Manual de Investigação em Educação. Lisboa: Fundação Calouste Gulbenkian, 2000. 374 p. 
TULL, D. S.; HAWKINS, D. I. Marketing Research Measurement \& Method: a text with cases. 5. ed. [S.1.]: Macmillan, 1990.

UNITED NATIONS GLOBAL COMPACT. Overview of the UN Global Compact. United Nations Global Compact, 2011. Disponível em:

<http://www.unglobalcompact.org/AboutTheGC/index.html>. Acesso em: 25 setembro 2012.

UNITED NATIONS DEPARTMENT OF ECONOMIC AND SOCIAL AFFAIRS. Indicators of Sustainable Development: Framework and Metodologies. Division for Sustainable Development. New York, p. 294. 2001.

URBACH, N.; AHLEMANN, F. Structural Equation Modeling in Information Systems Research Using Partial Least Squares. Journal of Information Technology Theory and Application, 11, n. 2, june 2010. 5-40.

VELEVA, V.; ELLENBECKER, M. Indicators of sustainable development: framework and methodology. Journal of Cleaner Production, 9(6), 2001. 519-549.

VIEIRA, S. Introdução à Metodologia do Trabalho Científico. 4. ed. São Paulo: Atlas, 1999.

VINHAS, L. A DIRETORIA DE RADIOPROTEÇÃO E SEGURANÇA NUCLEAR. Rio de Janeiro. 2009.

VUOLO, J. H. Fundamentos da Teoria de Erros. 2. ed. São Paulo: Edgard Blucher Ltda, 1996.

WANG, L. A methodology of sustainability accountability and management for industrial enterprises. Buffalo, USA. 2005. Doctoral Dissertation, Faculty of graduate Scholl, The State University of New York at Buffalo.

WARHURST, A. Sustainability indicators and sustainability performance management. Warwick: University of Warwick, 2002.

WARTICK, S. L.; COCHRAN, P. L. The evolution of corporate social performance. Academy of Management, 1985. Disponível em: 〈http://www.jstor.org/pss/258044>. Acesso em: 04 dezembro 2011.

WARTICK, S. L.; COCHRAN, P. L. The Evolution of The Corporate Social Performance Model. Academy of Management Review, 10, 1985. 758-769.

WASCHECK, C. História do Acidente Radioativo de Goiânia. Governo do Estado de Goiás. Goiânia. 2007.

WEINGRILL, C. Práticas empresariais de responsabilidade social: relações entre os princípios do Global Compact e os indicadores Ethos de responsabilidade social. São Paulo: Instituto Ethos, 2003. 
WHITTAKER, G.; LEDDEN, L.; KALAFATIS, S. P. A re-examination of the relationship between value, satisfaction and intention in business services. Journal of Sevices

Marketing, 21, n. 5, 2007. 345-357.

WOOD, D. J.; JONES, R. E. Stakeholder mismatching: a theoretical problem in empirical research on corporate social performance. The International Journal of Organization Analisys, Vol.3, n. 3, julho 1995. 229-267.

ZAGO, A. P. P. Sustentabilidade Corporativa: O Caso "Dow Jones Sustainability Index". Uberlandia. 2007. Dissertação (Mestrado) - Universidade Federal de Uberlândia. 